ANDRÉ LUÍS BERGAMASCHI

\title{
A RESOLUÇÃO DOS CONFLITOS ENVOLVENDO A ADMINISTRAÇÃO PÚBLICA POR MEIO DE MECANISMOS CONSENSUAIS
}

\author{
Dissertação de Mestrado \\ Orientador: Professor Associado Rodolfo de Camargo Mancuso
}

Faculdade de Direito da Universidade de São Paulo

São Paulo

2015 
ANDRÉ LUÍS BERGAMASCHI

\section{A RESOLUÇÃO DOS CONFLITOS ENVOLVENDO A ADMINISTRAÇÃO PÚBLICA POR MEIO DE MECANISMOS CONSENSUAIS}

Dissertação apresentada como requisito para a obtenção do grau de Mestre em Direito Processual Civil pelo Programa de Pós-Graduação da Faculdade de Direito da Universidade de São Paulo, desenvolvido sob a orientação do Professor Associado Rodolfo de Camargo Mancuso.

Faculdade de Direito da Universidade de São Paulo

São Paulo

2015 
Nome: BERGAMASCHI, André Luís.

Título: A resolução dos conflitos envolvendo a Administração Pública por meio de mecanismos consensuais

Dissertação apresentada como requisito para a obtenção do grau de Mestre em Direito Processual Civil pelo Programa de Pós-Graduação da Faculdade de Direito da Universidade de São Paulo, desenvolvido sob a orientação do Professor Associado Rodolfo de Camargo Mancuso.

Aprovada em:

Banca Examinadora

Prof. Dr.

Instituição:

Julgamento: Assinatura:

Prof. Dr. Instituição:

Julgamento: Assinatura:

Prof. Dr. Instituição:

Julgamento: Assinatura: 


\section{AGRADECIMENTOS}

A pesquisa, assim como o ensino e o aprendizado (atividades que muitas vezes se confundem, pois não são dadas pela sua posição em sala de aula, mas sim pela experiência que é sentida), não devem ser consideradas experiências individuais. Os frutos que delas provêm, tampouco devem ser atribuídos a tão somente o mérito próprio. A pesquisa tem que ser entendida como construção coletiva, assim como qualquer desenvolvimento aparentemente pessoal.

A presente pesquisa tem a contribuição de diversas pessoas, que, direta ou indiretamente, auxiliaram para a concepção e execução do projeto.

Agradeço ao meu orientador Rodolfo de Camargo Mancuso, pela orientação durante esses anos, e por incentivar seus orientandos a falar sobre aquilo que precisa ser dito sobre a realidade de nosso sistema jurídico. E também, por ser um referencial inigualável de dedicação a pesquisa e ensino.

Agradeço à Professora Fernanda Tartuce pelas mais diversas colaborações, pelas oportunidades em docência e pesquisa abertas, e pela inspiração que vem de suas escolhas por temas sempre com viés social. Certamente alguém decisivo para o resultado desses anos de pós-graduação.

Agradeço aos Professores Carlos Alberto de Salles e Antonio Rodrigues de Freitas Jr., por terem proporcionado disciplinas inovadoras, corajosas e importantes na pós-graduação da Faculdade de Direito da Universidade de São Paulo, que muito contribuíram para a concepção e execução desta dissertação.

Agradeço ao Professor Marcelo Bonício, pelas importantes considerações feitas em exame de qualificação.

A experiência acadêmica não é nada sem um dia-a-dia produtivo, cercado de boas pessoas, com quem é possível compartilhar ideias, obter e dar apoio para seguir em frente. Assim, agradeço a meus amigos Adriano, Guilherme, José Eduardo e Raul, pela convivência produtiva e engrandecedora, e pelo apoio que sei que recebo quase diariamente. 
Durante dois anos, o ambiente da Direito GV e da GVlaw me proporcionou um contato incrível com diferentes pesquisas e pesquisadores, temas e obras, projetos e ideias. Agradeço a todos que fizeram parte desse período: Bruna Pretzel, João Mendes, Rafael Zanatta, Pedro de Paula, Carolina Dalla Pacce, que foram meus companheiros de equipe, e tantas outras pessoas formidáveis, especialmente, à Andrea Zanetti, que coordenou meus trabalhos e tornou-se uma grande amiga, além de um exemplo de carinho com o trabalho.

Agradeço também a todas as pessoas que me acolheram no Departamento Jurídico XI de Agosto, e continuam me acolhendo até hoje. Nesse local, construí muito do que penso e ajo em relação a advocacia, a estudo e a pesquisa, especialmente os amigos com quem eu puder partilhar a gestão da entidade em 2009.

Por fim, agradeço a aqueles que me apoiam independentemente do que eu esteja fazendo, de qual projeto eu esteja engajado, de qual é minha posição geográfica.

Assim, agradeço a grandes amigos e companheiros: Gustavo Romero e Raíssa Belintani.

Agradeço enfim, à minha (grande) família, um grupo de muito amor, com quem sei que nunca deixarei de contar, e que são, cada um a sua maneira, importantíssimos referenciais: Waldecir, Clementino, Claudete, Oswaldo, Marco Antonio, Cláudia, José Augusto, Maria do Carmo, Júlio César, Cristiane, Rogério, Thaísa, Bento, Antonio, Maria Flor e Francisco. 


\section{RESUMO}

A presente dissertação investiga a possibilidade jurídica e as limitações da utilização de meios consensuais para resolução de conflitos que tenham a Administração Pública como parte. Mais especificamente, a dissertação tratará da escolha entre valer-se de meios consensuais para a solução do conflito ou de relegá-lo a um meio adjudicatório, especialmente o processo judicial. No primeiro capítulo, o trabalho situa a adoção dos meios consensuais pela Administração Pública no contexto de desenvolvimento das ADRs no Brasil, com influência da experiência norte-americana. No segundo, trata de revisitar alguns dogmas do Direito Administrativo que possam configurar óbices à adoção dos meios consensuais, como a legalidade estrita e a supremacia do interesse público, bem como situar novamente o tema no contexto de expansão da atuação administrativa consensual. O terceiro capítulo apresenta conceitos importantes para compreender a questão como: interesse público e indisponibilidade; meios adjudicatórios de solução de conflitos; meios consensuais de solução de conflitos (negociação, mediação e conciliação). No quarto capítulo, serão abordadas as limitações que o regime de direito público impõe à adoção de meios consensuais pela Administração Pública. O quinto capítulo traz um contraponto aos meios consensuais, relatando algumas críticas e riscos de sua adoção. Por fim, o sexto capítulo relata pesquisa empírica realizada na Procuradoria-Geral do Município de São Paulo com a finalidade de revelar experiências e óbices práticos à adoção de meios consensuais.

Palavras-chave: Meios alternativos de solução de conflitos. Meios consensuais de solução de conflitos. Negociação. Conciliação. Mediação. Administração Pública. Acordos administrativos. 


\begin{abstract}
This essay investigates the legal possibility and limitations of the use of consensual mechanisms of dispute resolution by Public Administration as one of the parties. More specifically, the essay addresses the choice between using consensual mechanisms to resolve the dispute or relegate it to adjudication, especially the judicial process. In the first chapter, the essay poses the use of consensual mechanisms by Public Administration in the context of ADRs development in Brazil, influenced by north american experience. In the second chapter, the essay revisits some tenets of Administrative Law that may constitute obstacles to the adoption of consensual mechanisms, such as strict legality and the supremacy of the public interest, and also poses the issue in the context of the expansion of consensual administrative action. The third chapter presents important concepts to understand the issue, such as: public interest and availability; adjudicatory mechanisms of dispute resolution; consensual mechanisms of dispute resolution (negotiation, mediation and conciliation). The fourth chapter adresses the limitations imposed by Public Law to the adoption of consensual mechanisms by Public Administration. The fifth chapter provides a counterpoint to consensual mechanisms, reporting some criticism and risks of its adoption. Finally, the sixth chapter reports empirical research conducted at São Paulo City's Attorney General Office in order to reveal experiences and practical obstacles to the adoption of consensual mechanisms.
\end{abstract}

Key-words: Alternative Dispute Resolution. Consensual Mechanisms of dispute resolution. Negotiation. Conciliation. Mediation. Public Administration. Administrative settlements. 


\section{SUMÁRIO}

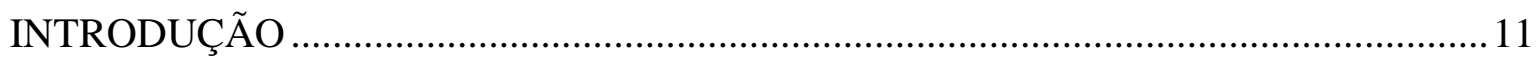

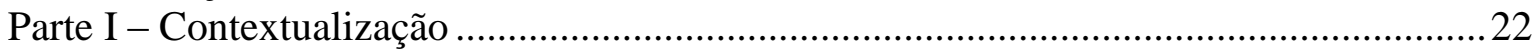

1. TRANSFORMAÇÕES DA RESOLUÇÃO DE CONFLITOS: Redescoberta e desenvolvimento dos mecanismos alternativos e revisitação do "acesso à justiça" ............ 22

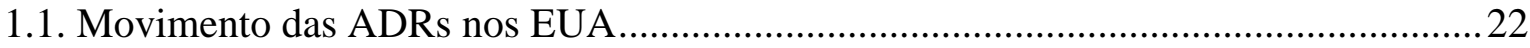

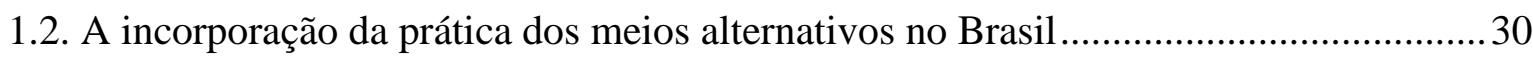

1.3. A compreensão contemporânea da "garantia do acesso à justiça" ................................ 32

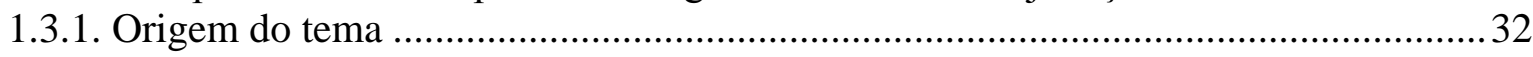

1.3.2. Compreensão contemporânea da garantia ............................................................. 34

1.3.3. Meios alternativos de solução de conflito como forma de expansão do acesso à

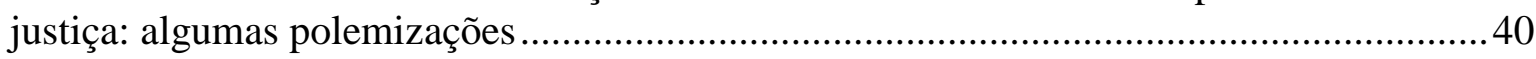
1.3.4. Essa concepção de acesso à justiça demanda a reformulação do conceito de

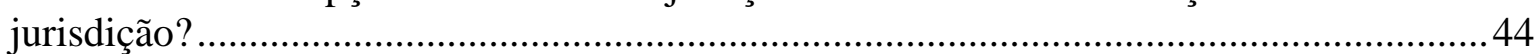

2. TRANSFORMAÇÕES NOS PARADIGMAS DO DIREITO ADMINISTRATIVO .... 48

2.1. Bases tradicionais do Direito Administrativo: supremacia e indisponibilidade do

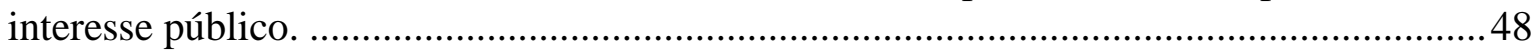

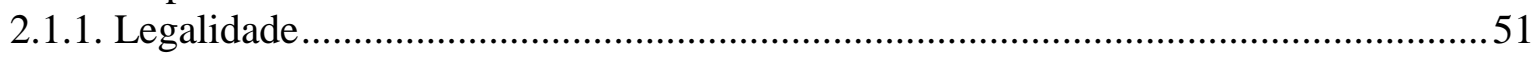

2.1.2. Reformulação do princípio da supremacia do interesse público ...............................53

2.2.1. Supremacia do interesse público como óbice para adoção de meios consensuais?...57

2.2. Introdução do princípio da eficiência como guia da atuação administrativa.................59

2.2.1. Eficiência na escolha do meio de atuação e de resolução de conflitos .......................61

2.3. Introdução do consenso como forma de atuação administrativa ...................................62

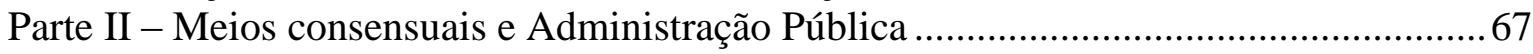

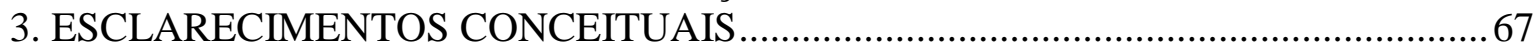

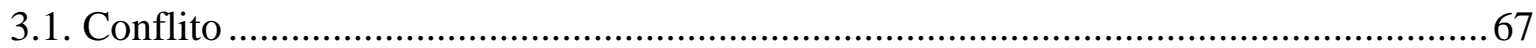

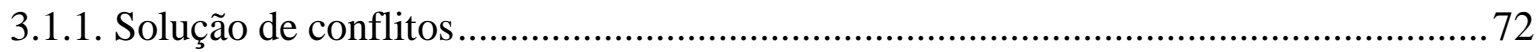

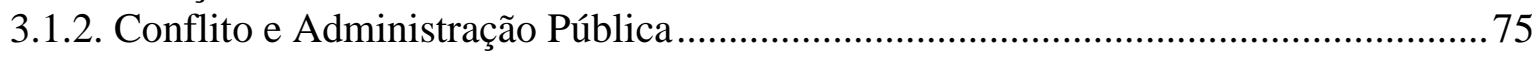

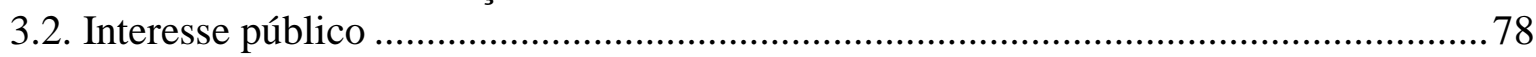

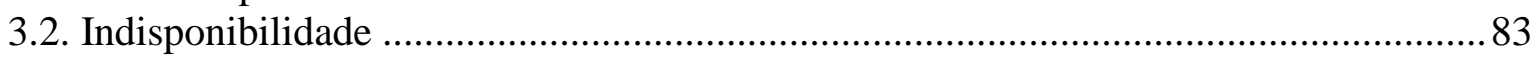

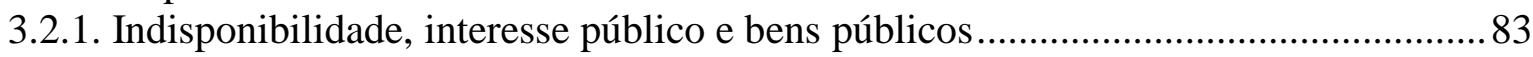

3.2.2. Interesse público primário e interesse público secundário?..................................... 87

3.2.3. A adoção dos meios consensuais de solução de conflitos implica em ato de

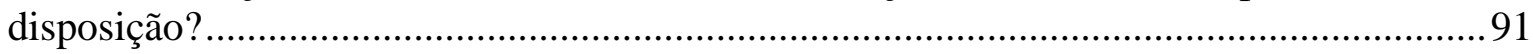

3.2.4. A indisponibilidade não significa necessária submissão ao processo judicial ..........94

3.3. Meios adjudicatórios de solução de conflitos .............................................................. 98

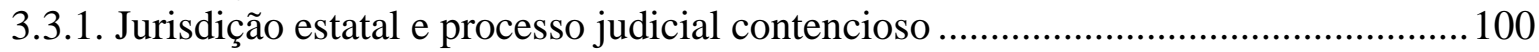

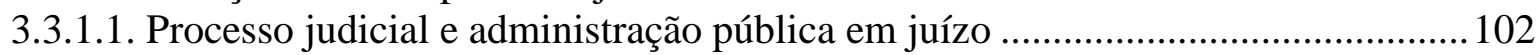

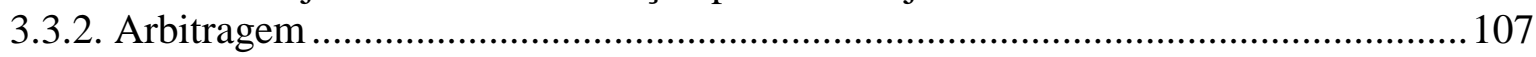

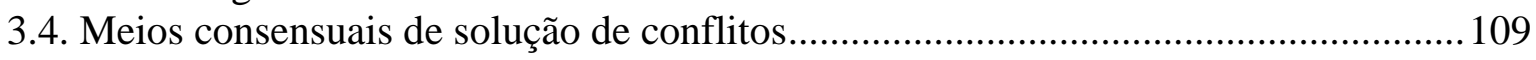

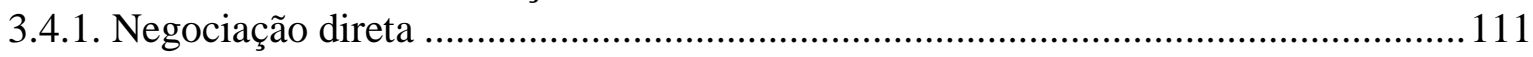

3.4.2. Conciliação e mediação ....................................................................................... 113

3.5. Combinação de ferramentas de solução de conflitos: Case management ou gerenciamento de processos....................................................................................... 125 4. LIMITES À UTILIZAÇÃO DOS MEIOS CONSENSUAIS PELA ADMINISTRAÇÃO

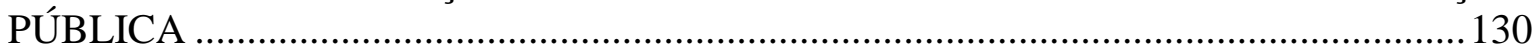

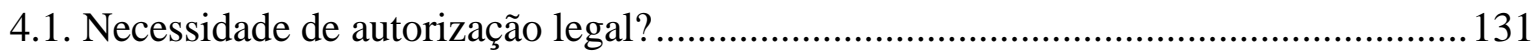


4.1.1. Panorama legal autorizativo da adoção de meios extrajudiciais e meios consensuais

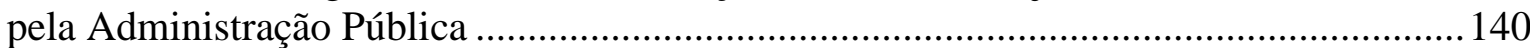

4.1.1.1 Adoção de mecanismos extrajudiciais de solução de conflitos ............................. 141

4.1.1.2. "Arbitragem" e conciliação no âmbito das Agências Reguladoras ....................... 148

4.1.1.3. Termos de compromisso (administrativos ou judiciais) .......................................151

4.1.1.4. Previsão de mecanismos consensuais e extrajudiciais de solução de conflitos entre entes da Administração Pública

4.1.1.5. Previsões legais para uso de meios consensuais no curso de processos judiciais 157

4.1.1.6. Perspectivas normativas: Projeto de Lei sobre mediação e Poder Público (PLC n.

7.169/2014) e Novo Código de Processo Civil (PLS-PCD n. ............................................. 161

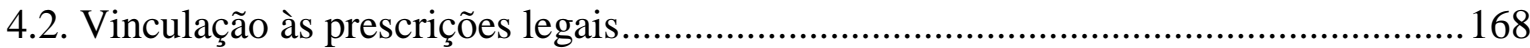

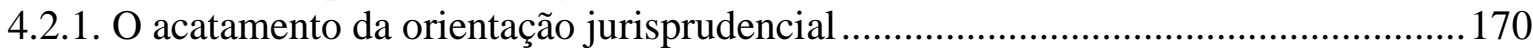

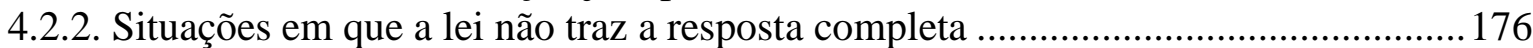

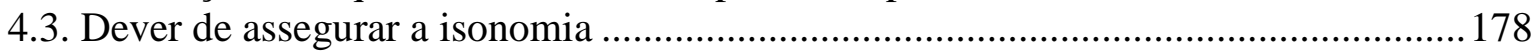

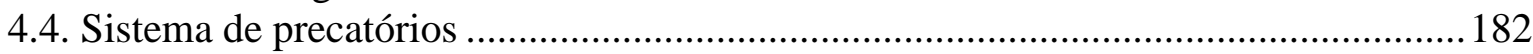

4.4.1. Pagamento por precatório: óbice à realização de acordo? ..................................... 185

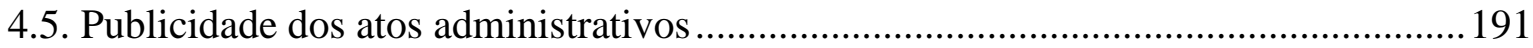

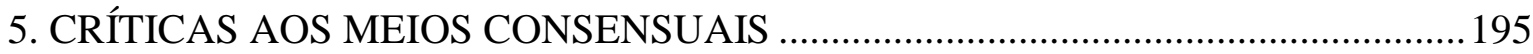

5.1. Inbalance of power: a desigualdade de forças na negociação pode promover

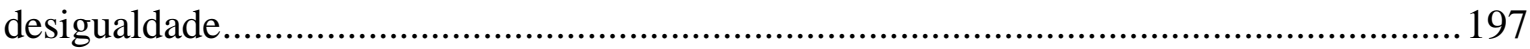

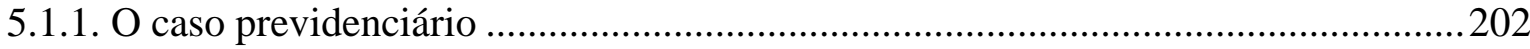

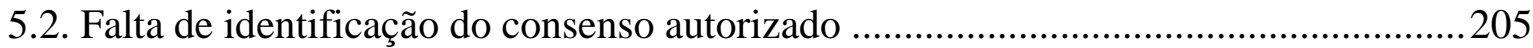

5.3. Falta de fundamento para o envolvimento judicial contínuo.......................................2. 210

5.4. As ADRs não são capazes de dar uma interpretação oficial da lei e do direito...........216

5.5. O inabalável critério numérico e a perda de qualidade do processo e de seu resultado

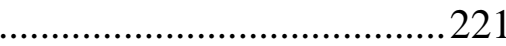

Parte III - Pesquisa realizada na Procuradoria-Geral do Município de São Paulo.............227

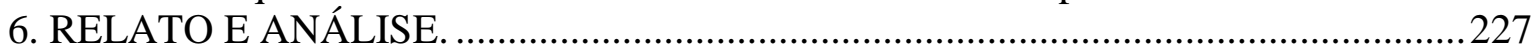

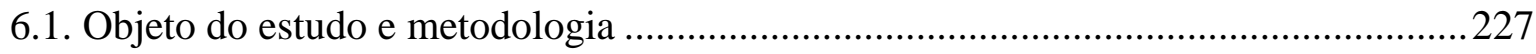

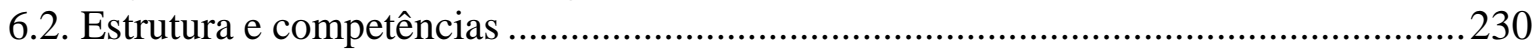

6.3. Relato: Práticas consensuais identificadas no âmbito da Procuradoria-Geral do

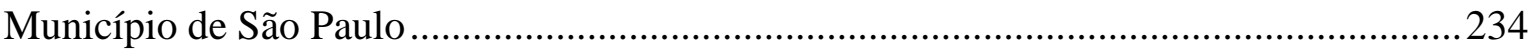

6.3.1. As experiências analisadas são autênticos "meios consensuais" institucionalizados na

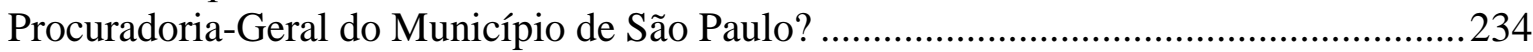

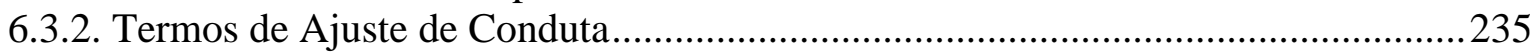

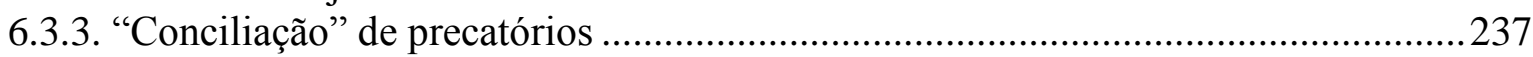

6.3.4. Pedido administrativo de indenizações por responsabilidade civil extracontratual 239

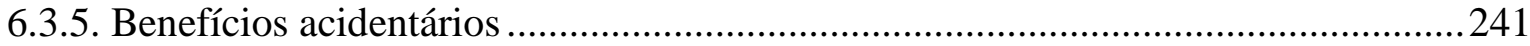

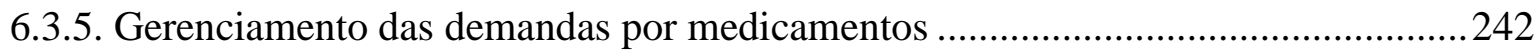

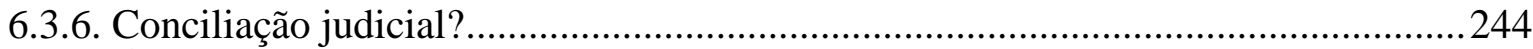

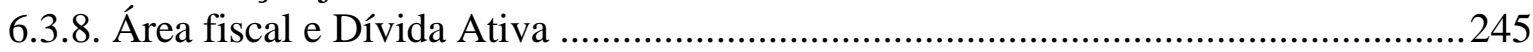

6.3.9. Mecanismos de prevenção de litígios: súmulas administrativas e normas de

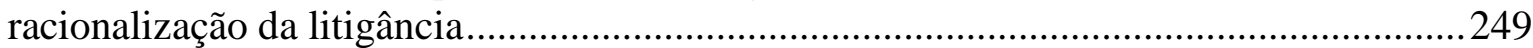

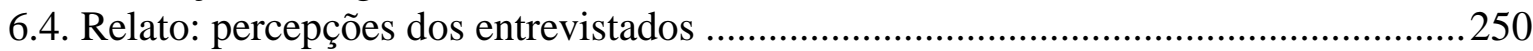

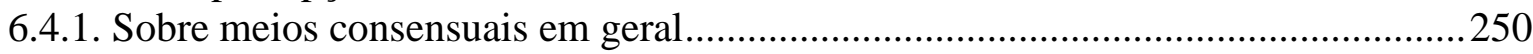

6.4.2. Sobre as vantagens dos meios consensuais e sede adequada para sua prática ........250

6.4.3. Sobre óbices para adoção dos meios consensuais ..................................................251

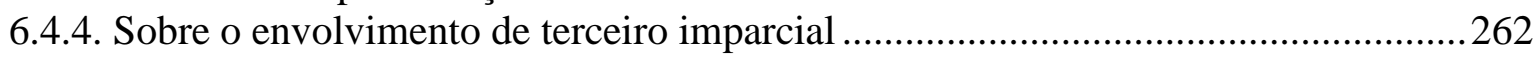

6.4.5. Alguns caminhos para o tratamento de conflitos no âmbito da PGM ......................2.263

6.5. Análise: há uso de meios consensuais no trato de conflitos no âmbito da PGM-SP? 264 
6.6. Análise: causas que influenciam o grau de utilização do uso de meios consensuais na

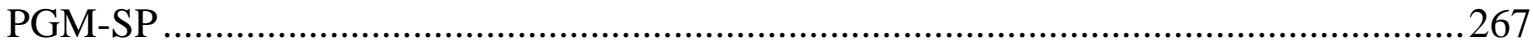

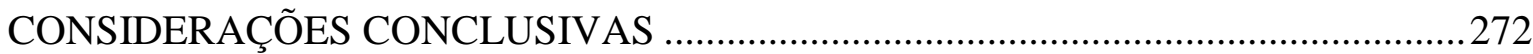

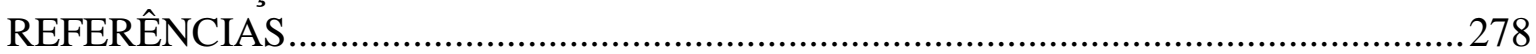

Apêndice 1 - Roteiro de entrevista utilizado na PGM-SP............................................228 


\section{INTRODUÇÃO}

A presente dissertação de mestrado investigará a possibilidade jurídica e as limitações da utilização de meios consensuais ${ }^{1}$ para resolução de conflitos que tenham a Administração Pública ${ }^{2}$ como parte.

Mais especificamente, a dissertação tratará da escolha da Administração em valerse de meios consensuais para a solução do conflito ou de relegá-lo a um meio adjudicatório $^{3}$, especialmente o processo judicial.

O trabalho não diferenciará a utilização do meio consensual antes da instauração do processo judicial (evitando-se a judicialização) da sua utilização durante a tratamitação do feito já instaurado (evitando-se a solução adjudicatória), pretendo tratar o tema a partir de suas discussões gerais.

\footnotetext{
${ }^{1}$ Por meios consensuais, adotaremos a explicação de Salles, para que meios consensuais são "uma ordenação de meios para gerar condições objetivas e predispor as partes para a realização de um acordo" (SALLES, Carlos Alberto de. Mecanismos alternativos de solução de controvérsias e acesso à justiça: inafastabilidade da tutela jurisdicional recolocada. FUX, Luiz; NERY JR., Nelson; WAMBIER, Teresa Arruda Alvim (coor.). Processo e Constituição: Estudos em homenagem ao Professor José Carlos Barbosa Moreira. São Paulo: RT, 2006, p. 779-792, p. 786).

2 Aqui se adota parcialmente o sentido subjetivo da expressão "Administração Pública", segundo o proposto por Marçal Justen Filho, para quem "numa acepção subjetiva, Administração Pública é o conjunto de pessoas, públicas e privadas, e de órgãos que exercitam atividade administrativa” (JUSTEN FILHO, Marçal. Curso de Direito Administrativo. 2. ed. São Paulo: Saraiva, 2006, p. 91). Disse-se parcialmente porque, apesar da constante intersecção entre Direito Público e Privado, para fins desse trabalho não abrangeremos as pessoas privadas que exercem atividade administrativa, por se submeterem a regime diverso de representação, responsabilização, disposição de bens, submissão ao Judiciário, etc. Para as especificidades que aqui serão retratadas, adota-se a concepção mais restritiva de Celso Antonio Bandeira de Mello, para quem "o aparelho estatal exercente de atividades administrativas é composto pela própria pessoa do Estado, atuando por meio de suas unidades interiores - os órgãos - e por pessoas jurídicas que cria para auxiliá-lo em seus misteres - as autarquias, as empresas públicas, as sociedades de economia mista e as fundações governamentais, que, na linguagem legal brasileira, constituem a administração indireta. (...) não se incluem particulares que também podem exercer atividade pública, devidamente habilitados pelo Estado" (MELLO, Celso Antônio Bandeira de. Curso de Direito Administrativo. 28. ed., São Paulo: Malheiros, 2011, p. 137138). Ainda, como o trabalho se ocupa das limitações exclusivas do regime jurídico estritamente público, o trabalho é forçado a excluir da abrangência do termo "Administração Pública" as empresas públicas e sociedades de economia mista, que se submetem ao regime privado temperado por força do art. $173, \S 1^{\circ}$, inciso II, da Constituição Federal. Ressalta-se que a presente restrição não se dá em ignorância em relação à importância que sujeitos privados, empresas públicas e sociedades de economia mista exercem na realização das funções administrativas, nem em relação à renovação do objeto de estudo do Direito Administrativo, que abrange toda essa gama de sujeitos. Dá-se, somente, porque o regime estritamente público é que aparenta apresentar as maiores restrições à utilização de mecanismos consensuais de solução de disputas, e é com dessas restrições que o presente trabalho se ocupa.

${ }^{3}$ Para fins desse trabalho, adotamos a explicação de Carlos Alberto Salles, segundo o qual adjudicação refere-se "à atividade pela qual um terceiro, estranho às partes, analisa o caso, indicando uma solução imperativa" (SALLES, Carlos Alberto de. Mecanismos alternativos de solução de controvérsias e acesso à justiça, cit., p. 786). Como se vê, adjudicação não corresponde apenas ao processo judicial, mas a qualquer meio heterocompositivo dotado de imperatividade. Dessa forma, o autor inclui entre as sedes adjudicatórias os foros administrativos, como o CADE e os Tribunais de Contas, e a arbitragem (SALLES, Carlos Alberto de. Mecanismos alternativos de solução de controvérsias e acesso à justiça, p. 787-788).
} 
Por força da grande variedade de instrumentos consensuais hoje conhecidos pela teoria e pela prática ${ }^{4}$, a pesquisa se restringirá à negociação direta, à conciliação e à mediação (judiciais ou extrajudiciais), meios mais usuais no Brasil, sem prejuízo de breves notas sobre outros mecanismos identificados durante a pesquisa.

Por fỉm, a dissertação buscará, mediante pesquisa empírica a ser realizada no âmbito da Procuradoria do Município de São Paulo, investigar se a Administração Pública efetivamente se vale de meios consensuais de solução de conflitos ou se utiliza precipuamente os meios ajudicatórios, além das causas (culturais, institucionais e normativas) que levam a optar por uma ou outra via.

No argumento de Marc Galanter, repeated players são aqueles litigantes que se envolvem em inúmeros litígios similares ao longo do tempo ${ }^{5}$. O Poder Público no Brasil pode ser enquadrado na noção de Galanter como grande litigante. Sua presença no Judiciário brasileiro é constante e sua atuação contenciosa dá origem a lides que são, na maioria das vezes, massificadas e repetidas.

Levantamento feito pelo Conselho Nacional de Justiça (CNJ) revelou que o Poder Público, representado por órgãos da Administração direta ou indireta, lidera o ranking de maiores litigantes do Brasil. Segundo o relatório "100 maiores litigantes", de 2011, entre os 10 maiores litigantes no ranking nacional, há quatro representantes do Poder Público: em primeiro lugar, aparece o Instituto Nacional do Seguro Social - INSS (22,3\% do total de processos ativos até 31 de março de 2010); em terceiro lugar, a Fazenda Nacional (7,45\%); em quarto lugar, a União (6.97\%); e, em sexto, o Estado do Rio Grande do Sul $(4,24 \%)$. Ainda segundo o mesmo relatório, entre os cinco setores mais litigantes estão o Setor Público Federal (em primeiro lugar, com 38\%), o Setor Público Estadual (em terceiro lugar, com $8 \%$ ) e o Setor Público Municipal (em quinto lugar, com 5\%) ${ }^{6}$.

O relatório "100 maiores litigantes” elaborado em 2012 confirmou o Poder Público como grande litigante, apontando que o Setor Público Federal como o setor mais litigante, estando presente, no polo ativo ou passivo, em 12,14\% dos processos distribuídos no entre $1^{\text {o }}$ de janeiro de 2011 e 31 de outubro de 2011. O Setor Público Municipal apareceu em terceiro lugar com 6,88\% e o Setor Público Estadual em quarto, com 3,75\%. Dos 10

\footnotetext{
${ }^{4}$ Apenas a título exemplificativo: dispute boards (Cf. WALD, Arnoldo. A arbitragem contratual e os dispute boards. Revista de Arbitragem e Mediação. São Paulo:RT, n. 6, jul./set. 2005, p. 9-24) e desapropriação amigável (art. 22 do Decreto-Lei 3.365/41).

${ }^{5}$ GALANTER, Marc. Why the haves come out ahead: speculations on the limits of legal change. Law and Society Review, Denver, v. 9, n. 1, p. 95-160, 1974, p. 97.

${ }^{6}$ CONSELHO NACIONAL DE JUSTIÇA. 100 maiores litigantes. Brasília: CNJ, 2011, p. 5 e 14.
} 
maiores litigantes, 7 são entes públicos da Administração Pública direta ou indireta das três esferas federativas. O INSS aparece em primeiro lugar, estando presente em 4,38\% dos processos distribuídos no período ${ }^{7}$.

Os dados corroboram a afirmação de Rodolfo de Camargo Mancuso, feita anos antes, de que o Poder Público é nada menos que o grande cliente do Judiciário ${ }^{8}$.

Assumimos aqui as observações do autor supracitado, não como hipótese de pesquisa, mas para fins de ilustração, o que se intui do cenário em que se coloca o presente trabalho.

Afirma o autor que nossa realidade judiciária é marcada por uma cultura demandista muito forte, que induz a população a procurar a Justiça estatal antes de tentar outros meios auto e heterocompositivos ${ }^{9}$.

Como aponta, no âmbito da Administração Pública não é diferente. Ao longo do tempo, formou-se uma cultura de não se resolverem as questões no âmbito interno da Administração, o que acarreta a judicialização das controvérsias. Assim, fornece-se ao Poder Público o álibi de que "a questão está sub judice"10, o que é confortável e conveniente para evitar o efetivo enfrentamento da questão.

Como efeitos sensíveis dessa cultura, normalmente são apontados o crescimento exponencial do número de processos no Judiciário (com o qual a estrutura não consegue acompanhar) e a conseqüente morosidade no processamento e julgamento das causas e a queda na qualidade da prestação jurisdicional. Contudo, como aponta o autor supracitado, o próprio Poder Público diagnostica mal esse problema, cuidando mais de seus sintomas de que de suas causas. As respostas que têm sido oferecidas são alterações nas leis processuais e investimentos sucessivos e crescentes na estrutura do Judiciário, que não têm se mostrado satisfatórias ${ }^{11}$.

No âmbito dos conflitos do Poder Público, há ainda a tendência da transformação do Judiciário em uma "prestação primária". Como o Estado apresenta ineficiência em lidar com as demandas de prestações primárias básicas como saúde, educação, previdência, entre outras, os jurisdicionados se voltam ao Judiciário que acaba atuando como uma

\footnotetext{
${ }^{7}$ CONSELHO NACIONAL DE JUSTIÇA. 100 maiores litigantes - 2012. Brasília: CNJ, 2012, p. 8 e 15.

${ }^{8}$ MANCUSO, Rodolfo de Camargo. O plano piloto de conciliação em segundo grau de jurisdição, do Egrégio Tribunal de Justiça de São Paulo e sua possível aplicação aos feitos da Fazenda Pública. Revista dos Tribunais, n. 820, p. 11-49, fev./2004, p. 43.

${ }^{9}$ MANCUSO, Rodolfo de Camargo. A resolução dos conflitos e a função judicial. São Paulo: Revista dos Tribunais, 2009, p. 89.

${ }^{10}$ MANCUSO, Rodolfo de Camargo. O plano piloto de conciliação em segundo grau de jurisdição, do Egrégio Tribunal de Justiça de São Paulo e sua possível aplicação aos feitos da Fazenda Pública, p. 43.

${ }^{11}$ MANCUSO, Rodolfo de Camargo. A resolução dos conflitos e a função judicial, p. 88.
} 
"segunda instância" da Administração na qual podem pleiteá-las. Assim, proliferam-se as demandas judiciais por medicamentos, vagas em creche, aposentadorias, etc.

Essa é uma visão compartilhada por quem lida com alguma proximidade com o Poder Judiciário e o Poder Público e pode constatar a quantidade da demandas em face dos entes da administração pública direta ou indireta por efetivação individual de direitos sociais como saúde e educação.

Paralelamente ao aumento do número de processos na Justiça brasileira, tornaramse populares, especialmente no âmbito do Judiciário, os meios consensuais de solução de conflitos, como alternativa à solução adjudicatória, por serem em regra mais rápidos e menos custosos, sem contar a potencialidade que têm de fornecer respostas mais adequadas a certas controvérsias, ainda que tal vantagem fique em segundo plano na ótica quantitativa da justiça.

Não é de se estranhar que, no cenário descrito, surgissem propostas e discussões acerca da aplicação dos meios consensuais ao Poder Público. Rodolfo de Camargo Mancuso, por exemplo, publicou em 2004 o artigo "O plano piloto de conciliação em segundo grau de jurisdição, do Egrégio Tribunal de Justiça de São Paulo e sua possível aplicação aos feitos da Fazenda Pública”, em que, após análise das possíveis limitações, conclui e defende a plena utilização desses meios ${ }^{12}$.

Como afirma Marcella Araújo da Nova Brandão, a habitualidade da administração pública em freqüentar o Judiciário deveria ser um facilitador na utilização dos meios consensuais e na condução de acordos em relação aos particulares que, por outro lado, são litigantes eventuais e não apresentam um padrão de conduta pré-determinado ${ }^{13}$.

Contudo, a resolução consensual de conflitos que envolvem a Administração Pública, em uma primeira leitura, parece ainda encontrar resistência em questões teóricas e culturais.

Em primeiro lugar, a consagração histórica pelo Direito Administrativo da "supremacia do interesse público" como princípio fundante ${ }^{14}$, em sua interpretação

12 MANCUSO, Rodolfo de Camargo. O plano piloto de conciliação em segundo grau de jurisdição, do Egrégio Tribunal de Justiça de São Paulo e sua possível aplicação aos feitos da Fazenda Pública, p. 48-49.

${ }^{13}$ BRANDÃO, Marcella Araújo da Nova. A consensualidade e a administração pública em juízo. Dissertação (mestrado) - Escola de Direito da Fundação Getúlio Vargas, Rio de Janeiro, 2009, p. 13.

${ }^{14}$ A propósito, Celso Antônio Bandeira de Mello afirma que a supremacia do interesse público sobre o privado é condição de existência de qualquer sociedade. A expressão desse princípio é a possibilidade de a Administração constituir terceiros em obrigações por atos unilaterais (MELLO, Celso Antônio Bandeira de.

Curso de Direito Administrativo. 28. ed., São Paulo: Malheiros, 2011, p. 96). 
tradicional $^{15}$, inibe a ideia de que a Administração Pública possa se envolver em conflitos e, consequentemente, compô-los. Como aponta Carlos Alberto de Salles, o conflito parece não fazer parte do repertório do Direito Administrativo porque se entendem verticais as relações jurídicas com o Poder Público, nas quais esse se coloca em um patamar superior ao particular e onde tudo será resolvido pelo critério único da prevalência do interesse estatal sobre o do particular, por meio do exercício da autotutela estatal ${ }^{16}$, desdobrada nas prerrogativas da Administração Pública. Não haveria, portanto, porque se falar em situação conflituosa ou na sua composição.

Em segundo lugar, há o entendimento corrente de que os interesses da Administração são considerados absolutamente indisponíveis e, portanto, não podem ser objeto de transação ${ }^{17}$. Contudo, esta parece ser uma conclusão ampla demais. Rodolfo de Camargo Mancuso se opõe a tal construção, afirmando que é um engano que advém da associação superficial do interesse fazendário a um interesse público insuscetível de qualquer composição e de uma interpretação gramatical e simplista da redação não muito feliz de alguns dispositivos legais que tratam do tema da transação, como o art. 841 do Código Civil ("Só quanto a direitos patrimoniais de caráter privado se admite transação”) ou do art. 477 do Código de Processo Civil ("Quando o litígio versar sobre direitos patrimoniais de caráter privado, o juiz, de ofício, determinará o comparecimento das partes ao início da audiência de instrução e julgamento" ${ }^{18}$.

Entre outros efeitos, essa interpretação gerou uma corrente jurisprudencial que afirma que a ausência da audiência preliminar não gera nulidade nos feitos que envolvem a Fazenda Pública, sob o fundamento genérico de que "o interesse público não admite transação", em atitude que desestimula a tentativa de autocomposição por parte da administração ${ }^{19}$.

Não obstante, surgem leis prevendo expressamente a realização de conciliação pelo ente público, como é o caso do art. 10, parágrafo primeiro, da Lei n. 10.259/2001, que dispõe que "os representantes judiciais da União, autarquias, fundações e empresas

${ }^{15}$ Para maior compreensão sobre a reformulação do princípio da supremacia do interesse público, ver item 2.1.2.

${ }^{16}$ SALLES, Carlos Alberto de. A arbitragem na solução de controvérsias contratuais da Administração Pública. Tese (livre-docência), São Paulo, Faculdade de Direito da Universidade de São Paulo, 2010, p. 171172.

${ }^{17}$ Cf. MELLO, Celso Antônio Bandeira de. Curso de Direito Administrativo, cit., p. 74-75.

${ }^{18}$ MANCUSO, Rodolfo de Camargo. O plano piloto de conciliação em segundo grau de jurisdição, do Egrégio Tribunal de Justiça de São Paulo e sua possível aplicação aos feitos da Fazenda Pública, cit., p. 40.

${ }^{19}$ REsp 242.322-SP; REsp 35.234-SP e 152.431-RS. 
públicas federais, bem como os indicados na forma do caput, ficam autorizados a conciliar, transigir ou desistir, nos processos da competência dos Juizados Especiais Federais".

Há ainda leis que estimulam a realização de transação e conciliação pelos entes públicos, ainda que as condicionando às leis que lhe são próprias, como, por exemplo, o art. $8^{\circ}$ da Lei 12.153/2009 (Lei dos Juizados Especiais da Fazenda Pública), que prevê que “os representantes judiciais dos réus presentes à audiência poderão conciliar, transigir ou desistir nos processos da competência dos Juizados Especiais, nos termos e nas hipóteses previstas na lei do respectivo ente da Federação".

Evidenciam-se também práticas efetivas de conciliação e mediação envolvendo o Poder Público. A Previdência Social, já em 2007, noticiava com entusiasmo a quantidade de acordos judiciais realizados com segurados por intermédio da Procuradoria do INSS, que representaram, segundo a notícia, uma economia de $\mathrm{R} \$ 10,2$ milhões, que seriam utilizados para pagamento de juros de $1 \%$ ao mês, além de pagamento de honorários advocatícios no caso de recursos. Segundo a notícia, já havia, na época, estímulo à capacitação de servidores para atuação nas audiências de conciliação ${ }^{20}$.

Em 2013, a Previdência Social, preocupada com o dispêndio de recursos que a alta litigiosidade acarreta, anunciou a criação dos Núcleos de Conciliação Administrativa, cujo objetivo é resolver litígios entre segurados e o INSS em grau de recurso administrativo, ou seja, antes de sua judicialização ${ }^{21}$.

Por outro lado, a Procuradoria-Geral do Estado da Paraíba veda absolutamente a realização de acordos em âmbito judicial, segundo parecer vinculante do Procurador-Geral do Estado publicado em 8 de dezembro de 2010 (Parecer 232/2010), ante a sistemática de precatórios instituída naquele ano e a ausência de regulamentação legislativa do assunto ${ }^{22}$.

Percebe-se que o tratamento da questão não é uniforme. É importante investigar a possibilidade e os limites da utilização de meios consensuais em controvérsias ligadas ao Poder Público para conferir ao assunto bases teóricas mais sólidas, que confiram maior segurança ao formulador de políticas de gestão de conflitos e aos atores que participantes da situação conflituosa.

${ }^{20}$ PROCURADORIA: INSS incentiva acordos em ações judiciais e processos são resolvidos com maior rapidez, 23/07/2007. Disponível em: <http://www.previdencia.gov.br/vejaNoticia.php?id=27809>. Acesso em: 29/06/2013.

${ }^{21}$ CONCILIAÇÃO: INSS poderá celebrar acordo administrativo no Conselho de Recursos, 31/01/2013. Disponível em: <http://www.mps.gov.br/vejaNoticia.php?id=48943>

22 IMPORTANTE Parecer da PGE veda acordos em Processos Judiciais. Disponível em: $<$ https://www.pge.pb.gov.br/portal/noticias/importante-parecer-da-pge-veta-acordos-em-processosjudiciais/>. Acesso em: 29/06/2013. 
Ademais, não basta encontrar a solução teórica caso se desconheça, na prática, os entraves culturais e institucionais à aplicação desses meios. A investigação empírica proposta tentará contribuir de alguma forma para essa identificação. Afinal, “[u]ma das finalidades das pesquisas acadêmicas em Direito, talvez a maior delas, reside no aprimoramento da funcionalidade de instituições e de seus correspondentes instrumentos jurídicos"23.

A presente dissertação parte de dois pontos de discussão: a resistência na prática e a resistência jurídica à adoção de meios consensuais de solução de conflitos pela Administração Pública.

Dentro desses âmbitos de discussão, a pesquisa se norteará por três questionamentos:

(1) É possível perante nosso Direito a adoção de meios consensuais antes ou durante ou instauração de processo judicial para resolução de conflitos que envolvam a Administração Pública como parte? Ou, havendo controvérsia, a questão deve necessariamente ser submetida à via judicial?

(2) Em caso positivo à questão anterior, as especificidades normativas que regem a atuação da Administração Pública impõem limites à adoção de meios consensuais?

(3) A Administração Pública, em sua atuação concreta, lança mão de meios consensuais de solução de conflitos? Ou os encaminha exclusivamente ao Judiciário? Quais os razões para uma ou outra conduta?

Em razão de haver certo número de instrumentos de atuação consensual da administração pública, o trabalho aprofundará apenas meios consensuais de solução de efetivos conflitos, instrumentos utilizados em uma relação jurídica controvertida ${ }^{24}$.

\footnotetext{
${ }^{23}$ PALMA, Juliana Bonacorsi de. Atuação Administrativa consensual: Estudo dos Acordos Substitutivos no processo administrativo sancionador. Dissertação (mestrado), São Paulo, Faculdade de Direito da Universidade de São Paulo, 2010, p. 17.

${ }^{24}$ Cf. OLIVEIRA, Gustavo Justino de. A Administração consensual como a nova face da Administração pública no século XXI: fundamentos dogmáticos, formas de expressão e instrumentos de ação. OLIVEIRA, Gustavo Justino de. Direito administrativo democrático. Belo Horizonte: Fórum, p. 211-231, 2010, p. 227 228. O autor adota uma distinção interessante entre transação administrativa e conciliação. Segundo ele, transação e conciliação administrativa fazem parte de um gênero mais amplo de acordos administrativos (que abrange modalidades contratuais, participação popular, etc), sendo sua especificidade o fato de incidirem em situação conflituosa. O presente trabalho diverge, contudo, da forma com que o autor descreve e distingue as duas expressões: para ele, conciliação é a transação facilitada por um terceiro. Contudo, não cremos que a única distinção entre a conciliação e a transação seja apenas a presença do terceiro, até porque a transação tem conceito normativo estrito demais (art. 840 do Código Civil), implicando "concessões recíprocas" de direitos, o que não necessariamente ocorrem em uma conciliação. A conciliação, por sua vez, na definição do autor, pode abranger também a mediação, que possui contornos um pouco diferentes.
} 
O caminho metodológico para se responder a tais questões se inicia com a elaboração das hipóteses a serem testadas. Como Rafael Queiroz explica, “[t]oda pesquisa deve começar com algo que não se sabe, ou de que não se tem certeza, ou cuja certeza intuitiva se quer testar. Sem isso, não se tem um verdadeiro tema de pesquisa, por mais que se disponha de um assunto de interesse" 25 .

No caso do presente trabalho, uma leitura preliminar dos textos de referência do assunto, leitura de notícias relacionadas, aulas já assistidas sobre o tema e conversas tidas com atores direta ou indiretamente envolvidos no problema possibilitaram a formulação de algumas afirmações:

Hipótese I - Não há óbice jurídico para a adoção de meios consensuais para solução de conflitos pela Administração Pública nem regra que o obrigue a submeter os conflitos ao Poder Judiciário, ainda que o regime jurídico que a difere dos particulares imponha limitações na forma e no conteúdo da solução consensual.

Crê-se que os possíveis óbices normalmente levantados para a solução de conflitos - supremacia do interesse público e indisponibilidade do interesse público - são insustentáveis teoricamente, ao menos da maneira como são expostos para fins de bloquear as soluções consensuais.

Contudo, outras restrições devem surgir devido ao regime jurídico próprio a que se submete tanto a atuação dos agentes estatais (ex.: responsabilidade por probidade administrativa e respeito hierárquico), quanto à atuação do Estado em juízo (ex.: pagamento por precatório), quanto à disposição de bens e valores públicos (ex.: autorização legal para remissão tributária, etc.).

Juliana Bonacorsi de Palma, em sua dissertação de mestrado, abordou hipótese semelhante $^{26}$ : o atual arcabouço normativo ampara a consensualidade ao prever módulos concertados e, ainda, determina a fungibilidade entre os instrumentos regulatórios ato unilateral e acordo administrativo, encerrando-se a adoção da consensualidade em uma decisão discricionária do administrador. Uma vez que (1) a prerrogativa pública é meramente instrumental, (2) a legalidade na seara da consensualidade guarda vinculação negativa à juridicidade e (3) os argumentos da indisponibilidade do interesse público e da

25 QUEIROZ, Rafael Mafei Rabelo. Como encontrar um bom tema dentro de minha área de interesse? QUEIROZ, Rafael Mafei Rabelo; FEFERBAUM, Marina (coord.). Metodologia jurídica: um roteiro prático para trabalhos de conclusão de curso. São Paulo: Saraiva, 2012, p. 56.

${ }^{26}$ PALMA, Juliana Bonacorsi de. Atuação Administrativa Consensual: Estudo dos Acordos Substitutivos no processo administrativo sancionador. Dissertação (mestrado), São Paulo, Faculdade de Direito da Universidade de São Paulo, 2010, p. 16. 
supremacia do interesse público sobre o interesse privado não são suficientes a obstacularizar a consensualidade, os acordos administrativos podem ser validamente celebrados pela Administração Pública ${ }^{27}$.

Ademais, o presente trabalho tentará contribuir para os estudos em consensualidade administrativa aportando para a discussão o conhecimento produzido na área de Direito Processual e do estudo das Soluções de Disputa, além de acrescentar o via judicial como contraponto à consensualidade.

Hipótese II - Os meios consensuais não substituem os adjudicatórios nem lhe são superiores, mas, dentro de certos loci e de certas circunstâncias, são preferíveis e mais adequados tomando como critério a eficiência e a isonomia de tratamento.

Mormente no atual estágio de inchaço judicial e perpetuação de litígios, muitos dos quais tendo a Administração Pública como parte, a saída consensual parece ser mais eficiente e, como a eficiência é diretriz de atuação, deve ser estimulada no âmbito estatal.

Contudo, a via judicial, ainda que racionalizada, deve ser conservada para assegurar mormente os casos em que o via consensual pareça ser inadequada ${ }^{28}$.

Hipótese III - Na prática, há pouco ou nenhum tratamento consensual de conflitos no âmbito da Administração Pública. Uma das razões para explicar o baixo nível de consensualidade é que a advocacia pública é resistente aos meios consensuais, pois seus membros, na média, acreditam que (i) a Fazenda Pública não negocia, apenas decide; (ii) a "indisponibilidade e a supremacia do interesse público" impediria qualquer meio consensual no caso de conflito, restando apenas a via adjudicatória no caso de impasse; (iii) a falta de regulamento não garante a segurança suficiente para os procuradores transigirem ou comporem consensualmente conflitos.

${ }^{27}$ É inevitável dialogar com o trabalho da autora, que atravessou caminhos teóricos parecidos com os que o presente deverá atravessar. Contudo, a identificação do problema é diversa. A dissertação de Juliana de Palma lida com a dicotomia "imperatividade - consensualidade", explorando a opção entre uso das prerrogativas administrativas ou uso de acordo substitutivo no âmbito do processo sancionador antitruste ${ }^{27}$. Já a presente dissertação procurará trabalhar a dicotomia “judicialização - desjudicialização (ou não judicialização)" e a opção entre tratar consensualmente ou judicializar (ativa ou passivamente) um conflito. Além disso, tratará apenas do uso de instrumentos consensuais no âmbito das situações conflituosas, que não é necessariamente o caso do processo sancionador antitruste.

${ }^{28} \mathrm{Na}$ linha do diálogo com a já mencionada dissertação de Juliana de Palma, a pesquisadora também aborda hipótese semelhante, porém mais entusiasta e sem ressalvas: "Assume-se como segunda hipótese que os acordos substitutivos são preferidos em detrimento da regulação pela via sancionatória em determinados casos porque são mais efetivos que a sanção administrativa (cumprimento espontâneo), evitam a judicialização da decisão (consensual), são medidas proporcionais ao potencial gravame, valorizam as finalidades setoriais ao conformar uma decisão mais consentânea com o caso concreto e trazem economia de tempo e custos” (PALMA, Juliana Bonacorsi de. Atuação Administrativa Consensual, cit., p. 17). 
A fim de tentar responder às perguntas e testas as hipóteses propostas, a dissertação se propõe a trilhar o seguinte caminho:

\section{Parte I - Contextualização}

- O Capítulo 1 tratará da investigação das bases teóricas e da evolução da incorporação de meios consensuais de solução de conflitos em alternativa ao mecanismo adjudicatório oficial, com base no estudo do início movimento das ADRs nos Estados Unidos e de sua apreensão pelo Judiciário Norte-Americano. Em seguida, investigará como o movimento repercutiu no Brasil e chegou ao nosso Judiciário, desde as primeiras iniciativas até tempos de Resolução n. 125/CNJ. Tratará, ainda, das recentes reformulações da compreensão da garantia do acesso à justiça.

- O Capítulo 2 tratará da investigação da reformulação das bases teóricas do Direito Administrativo que permitiram a introdução do consenso como forma de atuação administrativa, tanto no exercício de suas atribuições e competências quanto na resolução de conflitos.

- A conclusão parcial da Parte I investigará se e como esses dois movimentos se tangenciam, criando um ambiente propício à solução consensual de conflitos da Administração Pública tanto no âmbito do Poder Judiciário quanto internamente aos órgãos administrativos.

Parte II - Meios consensuais e Administração Pública

- O Capítulo 3 tratará de esclarecimentos conceituais importantes para o desenvolvimento do tema. Assim, serão tratados os seguintes conceitos, de forma geral e, em seguida, por método dedutivo, em aplicação específica para a Administração Pública: (i) conflito; (ii) interesse público; (iii) indisponibilidade; (iv) meios adjudicatórios de solução de conflitos; (v) meios consensuais de solução de conflitos; (vi) transação; (vii) conciliação; (viii) mediação; (ix) meios híbridos de solução de conflitos.

- O Capítulo 4 levantará possíveis limitações à solução consensual de conflitos envolvendo a Administração Pública, e investigará se constituem ou não condicionantes a essa forma de atuação. Serão tratados os seguintes temas: (i) autorização legal para a realização de acordo; (ii) critério legal para tomada de decisões; (iii) isonomia; (iv) sistema de precatórios; (v) publicidade dos atos administrativos.

- O Capítulo 5 revisitará a literatura que trata das vantagens e desvantagens envolvidas na opção pela solução consensual de conflitos, bem como às críticas feitas à 
utilização desses meios. Também por meio indutivo, essas considerações tentarão ser aproveitadas para a resolução de conflitos da Administração Pública.

- A conclusão parcial da Parte II trará a resposta às indagações elaboradas quanto à possibilidade e as limitações da utilização dos meios consensuais de solução de conflitos envolvendo a Administração Pública.

Parte III - Estudo de caso: Procuradoria-Geral do Município de São Paulo

Na última parte do trabalho, será abordado o estudo de caso que terá como objeto a atuação da Procuradoria-Geral do Município em relação à utilização de meios consensuais para a solução de conflitos.

- Na primeira parte do Capítulo 6, serão descrita as informações coletadas a partir da base documental pesquisada e de entrevistas com os atores envolvidos (a parte narrativa do estudo de caso).

- Na segunda parte do Capítulo, serão analisadas as informações coletadas e, a partir delas, será feito diagnóstico em duas partes (o tópico da análise do caso): (i) e efetiva utilização de meios consensuais, e sua comparação com os meios adjudicatórios; (ii) as causas da utilização maior ou menor dos meios consensuais. Há gargalos institucionais, culturais, ou normativos?

Por fim, a conclusão tentará relacionar as respostas aos três questionamentos feitos e dizer o resultado da pesquisa em relação às hipóteses formuladas. 


\section{Parte I - Contextualização}

\section{TRANSFORMAÇÕES DA RESOLUÇÃO DE CONFLITOS:}

\section{Redescoberta e desenvolvimento dos mecanismos alternativos e revisitação do "acesso à justiça"}

O presente capítulo se debruça sobre a literatura que descreve o surgimento e desenvolvimento do movimento das Alternative Dispute Resolutions (ADRs) nos Estados Unidos, bem como teoriza a introdução desses meios alternativos como ferramenta de justiça, e como essa cultura formada influenciou a tentativa da construção de soluções para a Poder Público e para a realidade brasileira.

É fato que a mediação e outros mecanismos de solução de conflitos existiram ao longo da história em paralelo com a solução oficial, “estatal” e impositiva. A própria mediação esteve presente como forte prática em diversas culturas, sobretudo nas orientais. A diferença do movimento de $\mathrm{ADRs}$ no século XX é que eles se tornaram prática institucionalizada e profissionalizada, inclusive relacionada com a participação democrática do indivíduo ${ }^{29}$.

Michele Taruffo ainda nos adverte que as ADRs, tanto na sua forma adjudicatória (arbitragem) como consensual (conciliação e mediação) sempre existiram, não se tratando de autêntica inovação. A novidade estaria, sim, na ênfase dada por doutrinadores e legisladores aos instrumentos alternativos, que deixam de vê-los como via subsidiária para resolução de conflitos e colocando-os como "via mestra", ocupando o centro do debate sobre administração da justiça civil ${ }^{30}$.

\subsection{Movimento das ADRs nos EUA}

29 MENDONÇA, Angela Hara Buonomo. A reinvenção da tradição do uso da mediação. Revista de Arbitragem e Mediação. São Paulo, RT, n. 3, p. 142-153, set./dez. 2004, p. 144.

${ }^{30}$ TARUFFO, Michele. Páginas sobre justicia civil (Trad. Maximiliano Aramburo Calle). Madrid: Marcial Pons, 2009, p. 113-114. 
O termo Alternative Dispute Resolution foi cunhado para designar as formas de resolução de conflitos que reemergiram ou surgiram no contexto de transformação nos Estados Unidos da litigância tradicional para uma desejada "cultura de acordo". A primeira menção do termo é atribuída a Frank Sander ${ }^{31}$. A partir desse movimento é que se iniciaram o interesse acadêmico no estudo desse tema, bem como o desenvolvimento de ideias e teorizações sobre a resolução alternativa de controvérsias que ganharam espaço em países não apenas da tradição da common law mas também da civil law.

Para entender o atual ambiente de valorização dos meios alternativos de solução de conflitos (termo que hoje por vezes é substituído por "meios adequados de solução de conflitos", destacando o fato de que ele pode ser o principal meio, e não o alternativo ${ }^{32}$ ), é importante compreender um pouco da gênese do movimento nos Estados Unidos e das bases teóricas que o sustentaram.

Carrie Menkel-Meadow explica que diversas mudanças históricas, como o movimento dos trabalhadores, a Grande Depressão, o New Deal e a Segunda Guerra Mundial, levaram à mudança de instituições nacionais e internacionais na forma de lidarem com resolução de conflitos. O "realismo jurídico" (legal realism) foi uma escola que surgiu de um ceticismo de que apenas lei e doutrina seriam suficientes para responder adequadamente aos problemas sociais, econômicos e políticos. Os esforços dessa corrente eram focados na reforma das instituições jurídicas tradicionais para que pudessem ser usadas em programas de "engenharia social" para lidar adequadamente com problemas importantes, como concorrência econômica e alocação de recursos escassos. Estudando a sociedade através da lei em ação (law in action), muitos realistas jurídicos desenvolveram leis mais responsivas às práticas sociais, como o Uniform Commercial Code ${ }^{33}$.

A autora dá especial destaque ao papel de Lon Fuller, professor da Harvard Law School e árbitro trabalhista, que fundou nos anos 50 outra escolar de pensamento, a Legal Process. Ele elaborou os princípios dos usos, para diferentes propósitos, da mediação, arbitragem, adjudicação, legislação, votação e outras formas institucionais de resolução de disputas. Esse autor propôs que cada processo tem sua funcionalidade e moralidade

\footnotetext{
${ }^{31}$ De acordo com: ROBERTS, Simon; PALMER, Michael. Dispute processess: ADR and the primary forms of decision-making. Cambridge: Cambridge University Press, 2005, p. 3-5.

${ }^{32}$ SILVA, Paulo Eduardo Alves da. Solução de controvérsias: métodos adequados para resultados possíveis e métodos possíveis para resultados adequados. SALLES, Carlos Alberto; LORENCINI, Marco Antônio Garcia. SILVA, Paulo Eduardo Alves da. Negociação, mediação e arbitragem: curso básico para programas de graduação em Direito. São Paulo: Método, 2012, p. 1-26, p. 11.

${ }^{33}$ MENKEL-MEADOW, Carrie. Roots and Inspirations: A Brief History of the Foundations of Dispute Resolution. MOFFITT, Michael L.; BORDONE, Robert C. (coord.). The Handbook of Dispute Resolution. San Francisco: Jossey-Bass, 2005, p. 13-31, p. 16.
} 
particulares. Assim, a mediação seria melhor para conflitos que envolvam relações continuativas (como nas relações familiares ou de trabalho), enquanto a arbitragem seria mais adequada para os casos em que as partes criaram suas regras autônomas (como nas relações comerciais), restando a adjudicação adequada apenas quando a interpretação da lei por uma autoridade estatal é necessária para a parte ou para a sociedade. Fuller percebeu que há profundas diferenças entre esses vários processos, desde o papel do terceiro envolvido até a forma como a solução da disputa deve ser recebida. Ele acreditava no que hoje é chamado de "pluralismo processual", ou seja, que os diferentes processos não se anulam, mas encontram seu espaço mais adequado na ampla gama de conflitos sociais e jurídicos ${ }^{34}$.

Essas teriam sido as contribuições teóricas decisivas para o desenvolvimento das ADRs. Sobre as causas conjunturais, Simon Roberts e Michael Palmer as posicionam, a partir da década de 60, em um contexto em que a adjudicação estatal, e, portanto, a litigância, dominaram a teoria e prática da Justiça, de tal forma que os advogados acabaram formando um monopólio do gerenciamento de conflitos. Além disso, o "acordo" e a "litigância" vinham sendo profundamente identificados, de modo que aquele acabou sendo obscurecido como algo apenas existente enquanto instrumento interno a uma ação judicial $^{35}$. A partir dessas constatações, algumas correntes de questionamento desse sistema se desenvolveram: (i) preocupações com os custos, demora e falta de acesso à adjudicação, revelando a necessidade de instrumentos mais informais, rápidos e baratos; (ii) questionamentos sobre as vantagens do acordo em relação à litigância; (iii)

34 MENKEL-MEADOW, Carrie. Roots and Inspirations: A Brief History of the Foundations of Dispute Resolution, cit., p. 17. De fato, textos originais do autor apontam para um sentido de adequação do conflito ao processo escolhido: "Ajudication is, then, a device which gives formal and institutional A decidion which is the product of reasoned argument to in human affairs. What kind of tasks are inherently unsuitede to adjudication? Thi introduces a concept - that of 'polycentric' tasks. (...) We are dealing with a situation of interacting poins of influence and therefore with a polycentric beyond the proper limits of adjudication. It may be Said ethat problems in the alocation of economic resources present too strong a polycentric aspect to be suitable for adjudication" (FULLER, Lon L. The forms and limits of adjudication. WINSTON. The principles of social order: selected essays of Lon L. Fuller, apud MENKEL-MEADOW, Carrie J.; LOVE, Lela Porter; SCHNEIDER, Andrea Kupfer; STERNLIGHT, Jean R. Dispute resolution: beyond the adversarial model. New York: Aspen, 2005. p. 21-22). Em outro texto: "Mediation and arbitration have distinct porposes and hence distinct moralities. The morality of mediation lies in optimu settlement, a settlement in which each party gives up what he values less, in return Fo what he values more. The morality of arbitration lis Iná a decision according to the law of the contract" (FULLER, Lon. L. Collective Bargaining and the arbitrator. apud MENKEL-MEADOW, Carrie J.; LOVE, Lela Porter; SCHNEIDER, Andrea Kupfer; STERNLIGHT, Jean R. Dispute resolution: beyond the adversarial model. New York: Aspen, 2005. p. 23).

35 ROBERTS, Simon; PALMER, Michael. Dispute processess: ADR and the primary forms of decisionmaking. Cambridge: Cambridge University Press, 2005, p. 45. 
questionamentos sobre instrumentos capazes de oferecer alternativas à litigância ou à forma agressiva de se firmar um acordo em meio a uma disputa judicial ${ }^{36}$.

Em 1976 ocorreu o Roscoe Pound Conference on the Causes of Popular Dissatisfaction with the Administration of Justice, evento no qual se apresentou o professor da Harvard University, Frank Sander, que já havia trabalhado anteriormente no Federal Mediation and Conciliation Service (Serviço Federal de Conciliação e Mediação), renomada agência norte-americana promovedora de soluções consensuais a empresas, sobretudo em litígios trabalhistas. Frank Sander inicia sua exposição de um ponto muito conhecido por todos nós: a crise numérica do Judiciário. Segundo artigo publicado por John Barton no ano anterior à Pound Conference ${ }^{37}$, se o número de novos recursos na Justiça americana continuasse a crescer como havia crescido na década de 60, no ano de 2010 haveria mais de um milhão de novos recursos por ano, o que demandaria 5 mil juízes federais para julgá-los, números que, para a época, soavam alarmantes. Assumindo, por outro lado, que as projeções nem sempre são exatas e que fatores imprevisíveis podem nelas interferir dramaticamente, a palestra pauta-se nos meios conscientes para evitar a concretização da previsão de John Barton ${ }^{38}$.

Intitulada "Varieties of Dispute Processing", a palestra propôs um modelo de corte judicial em que os casos não iriam todos para a adjudicação, mas passariam por diferentes portas de acordo com a necessidade do caso: mediação, arbitragem, conciliação, fact finding, entre outros, partindo de duas perguntas-chave: 1) quais as características dos diversos mecanismos de resolução de disputas; 2) como essas características podem ser utilizadas para o desenvolvimento de critérios racionais para alocar diversos tipos de conflitos em diferentes meios de solução ${ }^{39}$.

Outro fator importante destacado pelo palestrante é que podia ser observado o fenômeno de que os conflitos que eram normalmente resolvidos em outras instituições (como igrejas, família, bairro, etc) estavam sendo levados ao Judiciário com maior

${ }^{36}$ ROBERTS, Simon; PALMER, Michael. Dispute processess: ADR and the primary forms of decisionmaking. Cambridge: Cambridge University Press, 2005, p. 45-46.

${ }^{37}$ BARTON, John. Behind the legal explosion. Stanford Law Review, n. 27, 1975, p. 567 apud SANDER, Frank E. A. Varieties of Dispute Processing. LEVIN, Leo A.; WHEELER, Russell R (edit.). The Pound Conference: Perspectives on Justice in the future. St. Paul, MN: West Publishing, 1979, p. 65-87, p. 65.

${ }^{38}$ SANDER, Frank E. A. Varieties of Dispute Processing. LEVIN, Leo A.; WHEELER, Russell R (edit.). The Pound Conference: Perspectives on Justice in the future. St. Paul, MN: West Publishing, 1979, p. 6587, p. 65.

${ }^{39}$ SANDER, Frank E. A. Varieties of Dispute Processing. LEVIN, Leo A.; WHEELER, Russell R (edit.). The Pound Conference: Perspectives on Justice in the future. St. Paul, MN: West Publishing, 1979, p. 6587, p. 69. 
frequência. Ademais, o aumento da complexidade e da diversificação da sociedade fazia emergir novos conflitos que as Cortes não estavam sendo capazes de acompanhar ${ }^{40}$.

Em tal palestra, além de se valer de ensinamentos anteriores sobre diferentes "processos" de resolução de conflitos, o autor começa a delinear os contornos para avaliação da adequação de diferentes instâncias de resolução de conflitos para determinadas situações ${ }^{41}$.

Muitas considerações emergiram das observações de Sander ${ }^{42}$ :

1) o Judiciário já vinha perdendo espaço como instância pública exclusiva de resolução de conflitos, pois órgãos administrativos já vinham tentando compor conflitos inicialmente. Havia entre eles, contudo, diferenças substanciais. Para Sander, o momento era de diversificação processual da solução de conflitos;

2) Em um cenário de diversidade de meios de solução dos conflitos, o treinamento do advogado também deverá se diversificar, impondo novas obrigações aos órgãos da classe e às escolas de direito;

3) A concepção do "fórum" não apenas como um local de abrigo do Poder Judiciário, mas como um autêntico Centro de Resolução de Conflitos, em que um funcionário faz uma triagem prévia do caso e pode encaminhá-lo a diferentes "salas" em que se operam diferentes processos (ou a combinação deles), advindo daí a expressão Multi-Door Court.

Esse é considerado o Big Bang da teoria e prática modernas da resolução de $\operatorname{conflitos}^{43}$.

É necessário registrar nota de Kimberlee K. Kovach que, não obstante seja dado grande destaque à Pound Conference como element deflagrador do uso das ADRs, a

${ }^{40}$ SANDER, Frank E. A. Varieties of Dispute Processing. LEVIN, Leo A.; WHEELER, Russell R (edit.). The Pound Conference: Perspectives on Justice in the future. St. Paul, MN: West Publishing, 1979, p. 6587, p. 69.

${ }^{41}$ De especial relevância e prevendo fenômenos hoje observados no Brasil é a consideração feita a respeito de "aplicação de princípios estabelecidos para um grande número de casos individuais". Segundo o autor, a adjudicação nesse caso seria um meio adequado, mas não na forma de "litigância", ou seja, não no esquema tradicional de processo individual. Para ele, quando as Cortes já tiverem estabelecido princípios em algumas áreas, um procedimento mais rápido e menos fragmentado deve ser utilizado, não sendo as Cortes as instâncias mais adequadas para tanto (SANDER, Frank E. A. Varieties of Dispute Processing, cit., p. 72-73). Essas considerações parecem a base de reformas atuais como a súmula vinculante (que vincula a administração pública ao seu cumprimento, independente de decisão judicial individual) ou a arguição de preceito fundamental.

${ }^{42}$ SANDER, Frank E. A. Varieties of Dispute Processing. LEVIN, Leo A.; WHEELER, Russell R (edit.). The Pound Conference: Perspectives on Justice in the future. St. Paul, MN: West Publishing, 1979, p. 6587, p. 80-84.

43 MENKEL-MEADOW, Carrie. Roots and Inspirations: A Brief History of the Foundations of Dispute Resolution, cit., p. 19. 
mediação em si nos Estados Unidos tem raízes dissociadas do sistema legal, ligadas ao desenvolvimento de uma justiça comunitária a resolução de conflitos trabalhistas. Antes de 1976, já existiam programas originados de uma forma alternativa de justiça comunitária. A American Arbitration Association (AAA), por exemplo, promoveu programas-piloto de mediação financiados pela Fundação Ford no final dos anos 60 para acalmar as tensões sociais existentes, como Centros de Resolução de Disputas na Filadélfia e Rochester- NY. O primeiro programa efetivamente ligado ao Judiciário, segundo a autora, foi instalado em 1971 pelo Prosecutor's Office de Ohio, sendo um programa de mediação em que voluntários tratavam de casos que envolviam pequenos crimes. Contudo, o desenvolvimento sistematizado e a instalação de uma "política" de ADRs deve, de fato, ser atribuído aos esforços que se seguiram a partir da Pound Conference ${ }^{44}$.

A visão de Sander chamou a atenção de dois grupos: dos juízes, guiados pelo Chief Justice Warren Burger, da Suprema Corte norte-americana, que acreditavam haver muitos casos nas cortes e que atrasavam a resolução dos conflitos, os quais deveriam ser absorvidos por outros meios, dando ao movimento da resolução de disputas a tônica da quantidade e da eficiência; de outro lado, um movimento social mais difuso, inspirado pelos movimentos de empoderamento político dos anos 60, que buscava devolver às pessoas a condução de seus próprios conflitos e estava mais preocupado com a customização dos processos para necessidades individuais e coletivas específicas e menos com a profissionalização dos meios de solução de conflitos ${ }^{45}$.

Essas diferentes visões têm como ponto comum a noção de pluralismo processual advindo do Legal Process de Fuller. Essa noção predomina até os dias atuais, em que se buscam cada vez mais novas formas de solução de conflitos, que combinem as ferramentas primárias como negociação, mediação, arbitragem e adjudicação ${ }^{46}$.

O discurso de Sander deu origem ao conceito de tribunal multiportas (Multi-Door Courthouse $^{47}$ ), que em muitas cortes americanas recebeu incentivo dos governos e da

${ }^{44}$ KOVACH, Kimberlee K. Mediation: Principles and Practice. 3. ed. St. Paul: Thomson West, 2004, p. 3032.

${ }^{45}$ MENKEL-MEADOW, Carrie. Roots and Inspirations: A Brief History of the Foundations of Dispute Resolution, p. 19.

${ }^{46}$ MENKEL-MEADOW, Carrie. Roots and Inspirations: A Brief History of the Foundations of Dispute Resolution, p. 19.

${ }^{47}$ A ideia de sistema multiportas, segundo Marco Lorencini, comporta vários modelos: é possível que Estado disponibilize ou fomente a criação de diferentes meios de solução de conflitos, públicos e privados (mediação, conciliação, arbitragem, etc.), e coloque órgãos da Administração para orientação sobre as portas existentes. Também é possível que o cidadão, tendo procurado o Poder Judiciário para solucionar seu conflito, tenha à sua disposição várias portas, gerenciadas pelo Poder Judiciário, com um setor responsável pelo encaminhamento (modelo court-annexed) (LORENCINI, Marco Antônio Garcia Lopes. "Sistemas 
American Bar Association. Várias experimentações foram postas em prática: Neighborhood Justice Centres; Communitiy Board Mediation em São Francisco; programas de mediação, arbitragem e outras formas, ligados a diversas cortes (courtanexed arbitration and mediation $)^{48}$.

$\mathrm{Na}$ esfera comunitária, contudo, a tônica não era a eficiência, mas sim o empoderamento social, o informalismo, o fomento da democracia participativa, a redução da violência e da tensão entre grupos. Os entusiastas dessa vertente eram normalmente políticos progressistas. ${ }^{49}$. Há notícia três centros comunitários (Neighborhood Justice Centers) que foram projetos-piloto (Kansas City, Los Angeles e Atlanta), nos quais, valendo-se de mediadores voluntários, foram atingidos bons resultados em termos de satisfação das partes. Esses centros impulsionaram outras centenas de centros, que passaram a ser patrocinados, contudo, pelo Judiciário ou pela Bar Association local ${ }^{50}$.

Outras repercussões do movimento foram: o desenvolvimento da mediação familiar nos anos 70; o crescimento das cláusulas arbitrais nos anos 80; o movimento de justiça restaurativa na esfera penal; o surgimento da área chamada Dispute System Design, desenvolvido para que, combinando diferentes ferramentas, o conflito tenha um instrumento muito adequado para sua resolução ${ }^{51}$.

No campo da Administração Pública, o modelo de mediação entre duas partes foi expandido e adaptado para os campos de facilitação das políticas públicas e de construção de consenso. Esses processos foram utilizados para melhorar a tomada de decisões conjuntas e para dar maior legitimidade a decisões sobre políticas públicas quando a sua implantação se dá em contexto de disputas políticas ${ }^{52}$.

Maria Cecília Araújo Asperti nos narra a proliferação de atos oficiais de implantação e estímulo de meios alternativos nos Estados Unidos: mudanças nas Federal Rules of Civil Procedure, especialmente na Rule 16, que regulamenta audiência que deve

multiportas": opções para tratamento de conflitos de forma adequada. SALLES, Carlos Alberto; LORENCINI, Marco Antônio Garcia. SILVA, Paulo Eduardo Alves da. Negociação, mediação e arbitragem: curso básico para programas de graduação em Direito. São Paulo: Método, 2012, p. 57-86, p. 73-74).

48 MENKEL-MEADOW, Carrie. Roots and Inspirations: A Brief History of the Foundations of Dispute Resolution, p. 19-20.

${ }^{49}$ MENKEL-MEADOW, Carrie. Roots and Inspirations: A Brief History of the Foundations of Dispute Resolution, p. 20.

${ }^{50}$ KOVACH, Kimberlee K. Mediation: Principles and Practice. 3. ed. St. Paul: Thomson West, 2004, p. 33.

51 MENKEL-MEADOW, Carrie. Roots and Inspirations: A Brief History of the Foundations of Dispute Resolution, p. 21.

52 MENKEL-MEADOW, Carrie. Roots and Inspirations: A Brief History of the Foundations of Dispute Resolution, p. 22. 
ser realizada antes do julgamento (pretrial); em 1983, a tentativa de acordo foi contemplada como matéria necessária a ser abordada na audiência; em 1993, uma emenda estabeleceu que, além de promover o acordo, o juiz poderia utilizar de procedimentos específicos para auxiliar as partes a chegarem a uma solução da disputa (mini-trials, summary juri trials, mediação, avaliação neutra de terceiro, arbitragem não vinculante); em 1990, foi promulgado o Civil Justice Reform Act (CJRA), determinando que as cortes federais (district courts) desenvolvessem planos para redução dos custos e da duração do processo, inclusive a promoção de meios justos, céleres e menos custosos de resolução de disputas cíveis; em 1998, foi aprovado ainda o Alternative Dispute Resolution Act, que exigia das Cortes formulação de autorização, mediante regulamentação específica, do uso de meios alternativos de resolução de controvérsias em todas as ações cíveis ${ }^{53}$.

Luciane Moessa de Souza nos relata que, em 1996, foi editado o Administrative Dispute Resoluction Act, estabelecendo uma "política de gestão de conflitos e uso dos meios alternativos de disputas" a serem utilizados nos processos administrativos, regulamentos administrativos, administração de contratos, processos judiciais, emissão e revogação de licenças e autorizações. Contudo, o Report for the President on the use and results of alternative dispute resolution in the Executive Branch of the Federal Government, elaborado em 2007, concluiu que a maioria das agências federais ainda não utiliza os métodos alternativos na medida em que deveriam ${ }^{54}$.

$\mathrm{O}$ ato ainda prevê alterações no United States Code ${ }^{55}$ no tocante ao procedimento administrativo (Title 1, Part 1, Chapter 5), onde passou a ser prevista autorização genérica para as agências federais utilizarem procedimentos de resolução de conflitos para controvérsias concernentes a um programa da Administração, se as partes concordarem ${ }^{56}$, estabelecendo, ainda, sugestões de seus limites ${ }^{57}$.

53 ASPERTI, Maria Cecília de Araújo. Meios consensuais de resolução de disputas repetitivas: a conciliação, a mediação e os grandes litigantes do Judiciário. Dissertação (Mestrado) - Faculdade de Direito da Universidade de São Paulo. São Paulo, 2014, p. 62.

${ }^{54}$ SOUZA, Luciane Moessa de. Meios consensuais de solução de conflitos envolvendo entes públicos: negociação, mediação e conciliação na esfera administrativa e judicial. Belo Horizonte: Fórum, 2012, p. 244.

55 O United States Code é uma consolidação e codificação por matéria de leis gerais e permanentes dos Estados Unidos, preparada pelo Office of the Law Revision Counsel of the United States House of Representatives. Disponível em: < http://uscode.house.gov/>. Acesso em: 01.10.2014.

56 Disponível em: < http://uscode.house.gov/view.xhtml?req=granuleid:USC-prelim-title5section572\&num=0\&edition=prelim>. Acesso em: 01.10.2014.

${ }^{57}$ É questão que voltaremos em tópico apropriado (Capítulo 5), mas o Administrative Dispute Resoluction Act já antecipou algumas situações em que abrir mão da adjudicação estatal poderia ser inadequado: “(b) An agency shall consider not using a dispute resolution proceeding if- (1) a definitive or authoritative resolution of the matter is required for precedential value, and such a proceeding is not likely to be accepted generally as an authoritative precedent; (2) the matter involves or may bear upon significant questions of Government 


\subsection{A incorporação da prática dos meios alternativos no Brasil}

Relatam Diego Faleck e Fernanda Tartuce ${ }^{58}$ que, no Brasil, previsões sobre conciliação são contempladas há muito tempo. Posteriormente, regras esparsas passaram na seara trabalhista passaram a mencionar a "mediação" e, apesar de sua pouca aplicação, a pertinência de seu uso passou a ser notada a partir de contribuições doutrinárias trazidas do exterior por estudiosos brasileiros ${ }^{59}$.

As ADRs no Brasil também ganharam força com a promulgação da Lei de Arbitragem, em 1996, que previu a obrigatoriedade da cláusula compromissória e a desnecessidade de homologação judicial do laudo arbitral, o que enfim viabilizou o uso do instituto $^{60}$.

Quanto às soluções consensuais, antes de o Poder Judiciário abraçá-las, institucionalizá-las e promovê-las como política judiciária, muitas iniciativas destacaramse, dentre as quais: o Balcão de Direitos da ONG "Viva o Rio", que promoveu Mediações Comunitárias na favela da Rocinha; a Câmara de Mediação e Arbitragem (CMA) ligada ao serviço de assistência judiciária da Pontifícia Universidade Católica de Minas Gerais (PUC-MG); em Pernambuco, projeto de mediação da Fundação Joaquim Nabuco; no Ceará, a Casa de Mediação Comunitária ${ }^{61}$. Além disso, o Departamento Jurídico do Centro Acadêmico XI de Agosto mantém, desde a década de 90, convênio com o Instituto de Mediação e Arbitragem do Brasil (IMAB), pelo qual oferece gratuitamente aos seus

policy that require additional procedures before a final resolution may be made, and such a proceeding would not likely serve to develop a recommended policy for the agency; (3) maintaining established policies is of special importance, so that variations among individual decisions are not increased and such a proceeding would not likely reach consistent results among individual decisions; (4) the matter significantly affects persons or organizations who are not parties to the proceeding; (5) a full public record of the proceeding is important, and a dispute resolution proceeding cannot provide such a record; and (6) the agency must maintain continuing jurisdiction over the matter with authority to alter the disposition of the matter in the light of changed circumstances, and a dispute resolution proceeding would interfere with the agency's fulfilling that requirement".

${ }^{58}$ TARTUCE, Fernanda ; FALECK, D. Introdução histórica e modelos de mediação. TOLEDO, Armando Sérgio Prado de.; TOSTA, Jorge; ALVES, José Carlos Ferreira (Org.). Estudos Avançados de Mediação e Arbitragem. Rio de Janeiro: Elsevier, p. 171-189, 2014, p. 10-11.

${ }^{59}$ TARTUCE, Fernanda ; FALECK, D. Introdução histórica e modelos de mediação. TOLEDO, Armando Sérgio Prado de.; TOSTA, Jorge; ALVES, José Carlos Ferreira (Org.). Estudos Avançados de Mediação e Arbitragem. Rio de Janeiro: Elsevier, p. 171-189, 2014, p. 10-11.

${ }^{60}$ CARMONA, Carlos Alberto. Arbitragem e processo. 2. ed. São Paulo: Atlas, 2006, p. 22-23.

${ }^{61}$ MIRANDA NETTO, Fernando Gama de; MEIRELLES, Delton Ricardo Soares. Mediação judicial no Projeto do novo Código de Processo Civil (PL 8.046/2010). Revista de Arbitragem e Mediação, São Paulo, RT, v. 33, p. 213-235, abr./jun. 2012, p. 215-217. 
assistidos serviço de mediação para resolução dos conflitos que chegam à instituição, sendo adotadas medidas internas para fomentar a prática como preferencial em relação à solução adjudicatória. São de destaque ainda os planos-pilotos de conciliação instituídos em segundo grau pelo Tribunal de Justiça de São Paulo ${ }^{62}$.

Dados da Secretaria de Reforma do Judiciário datados de 2005 demonstram que, na metade da década passada, dentre os programas identificados envolvendo tratamento alternativo de conflitos, 49,2\% foram criados por entidades governamentais (60\% desses programas ligados ao Poder Judiciário), enquanto 47,7\% por entidades não governamentais $(16,4 \% \text { por ONGs criadas com esse propósito específico })^{63}$.

Contudo, todas essas iniciativas, além de sua fragmentação, careciam de um marco legal claro que definisse os limites do tratamento consensual de conflitos. A inércia do Legislativo em definir um marco para a matéria no Brasil levou o próprio Poder Judiciário, pelo seu órgão de controle, a ocupar este vácuo. Assim, o Conselho Nacional de Justiça emitiu a Resolução n. 125, de 29.11.2010, que procurou atuar como sucedâneo da lei inexistente na matéria e regulamentar a política de composição de conflitos, os núcleos de mediação e conciliação, bem como seus profissionais atuantes. A Resolução n. 125 do CNJ, chamada de "Política Nacional de Tratamento Adequado de Conflitos" é ainda usada como parâmetro para utilização dos meios alternativos de solução de controvérsias. Registre-se, contudo, que, não obstante outras propostas de regulamentação legal do tema já tenham existido no Congresso Nacional, está em trâmite na Câmara dos Deputados o Projeto de Lei n. 7169/2014, em estágio avançado do processo legislativo (já aprovado pelas Comissões de Constituição e Justiça das duas casas).

Diego Faleck e Fernanda Tartuce apontam que a experiência brasileira sofreu inegável influência do movimento norte-americano e que técnicas como "a mediação comercial e o desenho de sistemas de disputas já chegaram ao Brasil, que está habilmente delineando seus primeiros passos para a 'tropicalização' dos conceitos, princípios e proposições da teoria estrangeira" ${ }^{64}$.

62 Cf. Provimentos do Conselho Superior da Magistratura n. 783/2002 e 843/2004, disponíveis em: <www.tjsp.jus.br>.

${ }^{63}$ SECRETARIA DE REFORMA DO JUDICIÁRIO. Acesso à Justiça por Sistemas Alternativos de Administração de Conflitos. Brasília: SRJ, 2005, p. 24. Disponível em: < http://portal.mj.gov.br/reforma/main.asp?View=\%7B597BC4FE-7844-402D-BC4B-06C93AF009F0\%7D>. Acesso em: 01/11/2014.

${ }^{64}$ TARTUCE, Fernanda ; FALECK, D. Introdução histórica e modelos de mediação. TOLEDO, Armando Sérgio Prado de.; TOSTA, Jorge; ALVES, José Carlos Ferreira (Org.). Estudos Avançados de Mediação e Arbitragem. Rio de Janeiro: Elsevier, p. 171-189, 2014, p. 11. 


\subsection{A compreensão contemporânea da "garantia do acesso à justiça"}

A introdução de novas formas de resolução de conflitos além da judicial não apenas no seio da sociedade, mas também na própria política estatal de tratamento de conflitos, aliada ao cenário atual do Judiciário brasileiro, suscita a revisão dos conceitos de "acesso à justiça" e "jurisição", a fim de melhor situar teoricamente a questão.

\subsubsection{Origem do tema}

Em uma concepção bastante liberal e individualista, o acesso à justiça era visto como uma garantia formal, que se traduzia no direito do indivíduo em propor uma ação no Judiciário ou dela se defender. Sua efetivação não dependeria de nenhuma prestação positiva do Estado (além de manter o funcionamento do próprio Judiciário), e consistia em não permitir que outros o infringissem ${ }^{65}$. Não havia uma preocupação, teórica ou prática, com o efetivo acesso igualitário ao mecanismo estatal de solução de conflitos, desconsiderando-se fatores como diferenças entre litigantes em potencial, ou a disponibilidade de recursos para o litígio, que não eram vistos como problemas reais ${ }^{66}$. Isso refletia a própria concepção de igualdade formal do Estado Liberal. À medida em que avançaram reformas do Estado de bem-estar social, naturalmente o conceito de acesso à justiça evoluiu para a ideia de efetivo acesso ou, melhor, de que todos os cidadãos não tenham apenas os mesmos direitos proclamados, mas também garantidos instrumentalmente ${ }^{67}$.

O tema passa, necessariamente, pela pesquisa conhecida como "Projeto Florença" exposta no livro "Acesso à justiça". Sabe-se que está superada a leitura que se propagou a partir da pesquisa de que as "ondas renovatórias" seriam momentos próprios do desenvolvimento do acesso à justiça, hoje se propugnando que medidas ligadas às diversas

\footnotetext{
${ }^{65}$ CAPPELLETTI, Mauro; GARTH, Bryant. Acesso à justiça (Trad. Ellen Gracie Northfleet). Porto Alegre: SAFE, 1998, p. 9.

${ }^{66}$ CAPPELLETTI, Mauro; GARTH, Bryant. Acesso à justiça (Trad. Ellen Gracie Northfleet). Porto Alegre: SAFE, 1998, p. 9.

${ }^{67}$ CAPPELLETTI, Mauro; GARTH, Bryant. Acesso à justiça (Trad. Ellen Gracie Northfleet). Porto Alegre: SAFE, 1998, p. 11-12.
} 
ondas fluam simultaneamente ${ }^{68}$, aprimorando o sistema com frequência. Contudo, a importância das observações para a própria reconstrução do conceito justifica sua exploração no presente trabalho.

Assim, segundo o diagnóstico feito pelos autores e o levantamento de soluções práticas para problemas de acesso à justiça, dividiram-se as reformas de acesso à justiça em três ondas: (i) a primeira consistente na superação de óbices econômicos (soluções que contemplam desde a gratuidade do acesso ao Judiciário até acesso a serviços legais de orientação e representação); (ii) a segunda referente à necessidade de se dar representação de direitos "difusos" (hoje entendidos em nosso sistema como "metaindividuais"), superando técnicas de processo civil estritamente individual ${ }^{69}$. Contudo, até aí, o acesso à justiça ainda estava muito ligado à ideia de acesso ao Judiciário, ou seja, ao direito a uma solução adjudicada por uma autoridade estatal.

$\mathrm{O}$ interesse maior da pesquisa se voltou, na época, a uma perspectiva de desenvolvimento de um conjunto de instituições e mecanismos, pessoas e procedimentos utilizados para processar ou mesmo prevenir disputas, ao que os autores deram o nome de “enfoque do acesso à Justiça". O "enfoque" compreenderia, entre outras, reformas ligadas a uso de pessoas leigas ou paraprofissionais, mudanças no direito substantivo para evitar litígios ou facilitar sua solução e utilização de mecanismos privados ou informais. Entre as tendências verificadas na pesquisa, destacaram-se o uso de meios alternativos, como a conciliação, a arbitragem e os acordos extrajudiciais motivados por incentivos econômicos $^{70}$

Em acréscimo, ainda houve a advertência feita pelos autores de que

[o]s juristas precisam reconhecer que as técnicas processuais servem a funções sociais; que as cortes não são a única forma de solução de conflitos a ser considerada e que qualquer regulamentação processual, inclusive a criação ou o encorajamento de alternativas ao sistema judiciário formal tem um efeito importante sobre a forma como opera a lei substantiva ${ }^{71}$.

68 Cf. FALLEIROS, Carolina Teodoro. Alcance subjetivo das decisões judiciais sobre interesses metaindividuais. Dissertação (Mestrado) - Faculdade de Direito da Universidade de São Paulo. São Paulo, 2014 , p. 4.

${ }^{69}$ CAPPELLETTI, Mauro; GARTH, Bryant. Acesso à justiça (Trad. Ellen Gracie Northfleet). Porto Alegre: SAFE, 1998, p. 31-67, passim.

${ }^{70}$ CAPPELLETTI, Mauro; GARTH, Bryant. Acesso à justiça (Trad. Ellen Gracie Northfleet). Porto Alegre: SAFE, 1998, p. 71, 81-90.

${ }^{71}$ CAPPELLETTI, Mauro; GARTH, Bryant. Acesso à justiça (Trad. Ellen Gracie Northfleet). Porto Alegre: SAFE, 1998, p. 31-67, passim. 
Em nossa Constituição, o acesso à justiça ficou positivado o princípio na fórmula de "inafastabilidade da apreciação pelo Poder Judiciário" (art. 5, XXXV), o que suscita uma visão mais restrita se compreendida apenas na perspectiva literal.

A partir da visão da realidade sócio-econômica-política do Brasil, marcada por contradições sociais, mas, ao mesmo tempo, pela previsão de muitos direitos sociais, Kazuo Watanabe, em escrito datado de 1988, defende a leitura ampliativa do termo para que ele seja tido como "acesso à ordem jurídica justa", em uma visão que se preocupa com o direito substancial ajustado à realidade social e aplicado de modo correto. $\mathrm{O}$ autor inclui dentro dessa concepção a organização de instrumentos de solução de conflitos adequados às suas peculiaridades, defendendo o uso dos meios alternativos ${ }^{72}$.

Persistem leituras, por outro lado, da garantia do acesso à justiça limitado a (i) monopólio da jurisdição e (ii) direito de invocar a atividade jurisdicional sempre que se tenha como lesado ou ameaçado um direito ${ }^{73}$.

\subsubsection{Compreensão contemporânea da garantia}

Os problemas de se ter uma concepção de acesso à justiça cuja abrangência é restritiva em relação aos meios (limitada ao Judiciário), mas ampla em relação à sua incondicionabilidade do acesso são apontados por Rodolfo de Camargo Mancuso em recente escrito $^{74}$. Essas observações são de especial interesse ao presente trabalho, pois analisam de forma bastante acurada a relação entre Judiciário e Administração Pública.

$\mathrm{O}$ autor aponta que entre eles existe uma clara divisão de trabalho com base na separação de poderes. À Administração Pública cabe, primária e imediatamente, a gestão do interesse social, através da aplicação da lei e da adoção de condutas discricionárias, enquanto ao Judiciário restaria o papel de intervenção posterior, reservado a episódios de lesão ou ameaça de alegado Direito ${ }^{75}$. Desse trecho, inferimos que, segundo a divisão dos Poderes, ao Judiciário não caberia o papel de atender imediatamente o interesse público,

72 WATANABE, Kazuo. Acesso à justiça e sociedade moderna. GRINOVER, Ada Pellegrini; DINAMARCO, Cândido Rangel; WATANABE, Kazuo. Participação e processo. São Paulo: RT, p. 128135, 1988, p. 128-133.

${ }^{73}$ SILVA, José Afonso da. Comentário contextual à Constituição. 8. ed. São Paulo: Malheiros, 2012, p. 134.

${ }^{74}$ Cf. MANCUSO, Rodolfo de Camargo. O direito à tutela jurisdicional: o novo enfoque do art. $5^{\circ}, \mathrm{XXXV}$, da Constituição Federal. Revista dos Tribunais, São Paulo: RT, v. 926, dez./2012, p. 135-176

${ }^{75}$ MANCUSO, Rodolfo de Camargo. O direito à tutela jurisdicional,cit., p. 140. 
substituindo a função da Administração de mobilizar seus meios para provê-lo à população.

Contudo, o autor afirma que, como a Administração opera com recursos escassos, muitos reclames deixam de ser atendidos e episódios de lesão ou temor de lesão a direitos não são levados à instância administrativa ou, se levados, a solução é recusada ou insuficiente. Agregando-se a isso, temos uma forte cultura demandista, onde os atores não se prontificam a solucionar as controvérsias por outras vias, e, ainda, uma visão do acesso à Justiça lido como acesso ao Judiciário ${ }^{76}$.

Segundo Mancuso, a convergência desses fatores gera uma leitura exagerada da garantia do acesso à justiça, em que se vislumbra a imediata relação entre controvérsia $e$ demandada, ocasionando a judicialização de inúmeros conflitos em estágio não maduro, o que tem como efeitos: acirramento da contenciosidade social, retardamento dos ritos processuais, crise numérica dos processos, desestímulo à solução consensual, protraimento do desfecho da causa a um futuro indefinido ${ }^{77}$.

Ademais, dessa visão advêm externalidades negativas: 1) a judicialização de todo e qualquer interesse ameaçado torna-se a regra, gerando a expectativa de presteza do Judiciário, normalmente frustrada; 2) o Judiciário passa a se pautar por critérios mais quantitativos do que qualitativos, reduzindo a qualidade da $\operatorname{prestação~jurisdicional~}^{78} ; 3$ ) risco do direito de ação converter-se em dever de ação, deixando de lado outras possíveis soluções legitimas oficiais ou não; 4) manejo numérico de processos estimula a política

\footnotetext{
${ }^{76}$ MANCUSO, Rodolfo de Camargo. O direito à tutela jurisdicional, cit., p. 140-141.

${ }^{77}$ MANCUSO, Rodolfo de Camargo. O direito à tutela jurisdicional, cit., p. 141.

${ }^{78}$ Exemplo disso são as metas colocadas pelo Conselho Nacional de Justiça para julgamento de processos em atraso represados no Judiciário Brasileiro. A Meta 2, instituída em 2010, por exemplo, Meta 2: determinou como prioridade "julgar todos os processos de conhecimento distribuídos (em $1^{\circ}$ grau, $2^{\circ}$ grau e tribunais superiores) até 31 de dezembro de 2006 e, quanto aos processos trabalhistas, eleitorais, militares e da competência do tribunal do Júri, até 31 de dezembro de 2007”. Embora compreensível a pressão feita pelo órgão para que problemas mais antigos fossem solucionados, o critério exclusivamente numérico adotado nos documentos causou algumas distorções, como a busca da extinção do processo pelos juízes ou o condicionamento do direito de ação de maneiras ilegítimas, como fica evidenciado no seguinte julgado: "PROCESSUAL CIVIL. EXECUÇÃO DE TÍTULO EXTRAJUDICIAL. PROCESSO SUJEITO, EM TESE, À "META 2" DO CNJ. PRESCRIÇÃO INTERCORRENTE DECRETADA DE OFÍCIO. MANIFESTA INOCORRÊNCIA. DILIGÊNCIAS EM ANDAMENTO REGULAR. JURISPRUDÊNCIA DO STJ. PROVIMENTO DO RECURSO. ART. 557, § $1^{\circ}$-A , CPC . A denominada "Meta 2" do CNJ, à luz da garantia de duração razoável do processo (art. $5^{\circ}$, LXXVIII , CRFB ), preza a celeridade na tramitação dos feitos judiciais, não a extinção dos processos a qualquer custo.Logo, se o processo tramita regularmente, mediante zeloso acompanhamento do exequente, é completamente descabido o reconhecimento de prescrição intercorrente, pois ela "pressupõe diligência que o credor, pessoalmente intimado, deixa de cumprir no prazo prescricional" (RIO DE JANEIRO. Tribunal de Justiça. Apelação Cível n. 114090219998190002. Órgão Julgador: Décima Câmara Cível. Relator: Nemetala Machado Jorge. J. em: 31/11/2010. DJe em: 06/12/2010).
} 
judiciária e legislativa a lidar com as consequências (grande quantidade), deixando de diagnosticar e remediar as causas da alta litigiosidade ${ }^{79}$.

Um dos efeitos mais perversos identificados pelo autor é o fato de, em sistema de inchaço judicial e demora processual, o ligante eventual é sobrecarregado em face do litigante habitual que "trabalha em economia de escala na sua relação com a Justiça estatal (dispõe de advocacia de partido; conta com departamento jurídico bem estruturado), e por isso não lhe causam grande mossa as mazelas ou a ineficiência da estrutura judiciária, como se passa com litigante eventual" ${ }^{\prime \prime 0}$.

Para Maria Cecília de Araújo Asperti, contudo, o aumento da litigiosidade não é um dado por si só negativo. Seria um dado positivo se traduzisse um aumento do acesso da população ao sistema de justiça e da informação sobre seus direitos. Contudo, não é essa a situação quando a litigiosidade não reflete o acesso, mas sim "a falta de opções extrajudiciais de solução de conflitos ou o excesso de entraves burocráticos embutidos nas relações consumidor-fornecedor e cidadão-Estado, fazendo com que uma dessas partes tenha de inevitavelmente recorrer à via judicial" ${ }^{\prime 81}$.

Pelo diagnóstico de Mancuso, no mesmo sentido, parece não ser exatamente (ou primordialmente) a maior conscientização da população que impulsiona o aumento da litigiosidade contra a Administração Pública, mas sim problemas internos burocráticos ao reconhecimento de direitos. Diante dessas observações, a visão irrestrita do acesso à Justiça como possibilidade incondicionada de se levar ao Judiciário imediatamente qualquer controvérsia ao menor sinal de lesão ou ameaça de alegado Direito torna-se insustentável ${ }^{82}$.

Dessa forma, é proposta pelo autor uma reformulação do conteúdo do art. $5^{\circ}$, inciso XXXV, da Constituição Federal. A primeira colocação de reformulação se dá no plano teórico-dogmático, ou seja, de simples interpretação normativa. Neste ponto, não há que se entender o direito de ação como conteúdo irrestrito do dispositivo constitucional, pois o direito à obtenção e uma sentença de mérito é bastante condicionado ao preenchimento de

\footnotetext{
${ }^{79}$ MANCUSO, Rodolfo de Camargo. O direito à tutela jurisdicional, cit., p. 142.

${ }^{80}$ MANCUSO, Rodolfo de Camargo. O direito à tutela jurisdicional, p. 143.

81 ASPERTI, Maria Cecília de Araújo. Meios consensuais de resolução de disputas repetitivas: a conciliação, a mediação e os grandes litigantes do Judiciário. Dissertação (Mestrado) - Faculdade de Direito da Universidade de São Paulo. São Paulo, 2014, p. 73.

${ }^{82}$ Em nosso capítulo sobre a experiência da Procuradoria-Geral do Município, constatamos algumas medidas interessantes no âmbito do órgão que, ainda que não se autodefinam como "meios consensuais", promovem canais diferentes do Judiciário para o reconhecimento de direitos.
} 
pressupostos processuais e condições da ação (stricto sensu). Não é, portanto, a garantia a uma decisão de mérito.

Para Mancuso,

o que se vislumbra no inc. XXXV do art. $5^{\circ}$ da $\mathrm{CF} / 1988$ é uma diretriz, ou ainda uma mensagem dirigida ao legislador, avisando-o para que se exima de positivar situações e ocorrências desde logo e a priori excluídas de uma passagem judiciária na qual um órgão judicial competente e imparcial tomará conhecimento do histórico do dano temido ou sofrido ${ }^{83}$.

Assim como se dá com diversas categorias processuais, como a coisa julgada, o conceito de acesso à justiça também pode ser delimitado em textos normativos, como de fato é, tendo como exemplo condicionante prevista constitucionalmente o Tribunal Desportivo, pelo qual devem passar necessariamente os conflitos desportivos antes de serem encaminhados ao Judiciário (art. $217, \S 1^{\circ}$, da Constituição Federal), ou a vedação de mandado de segurança quando contra o ato impugnado couber recurso administrativo com efeito suspensivo (art. $5^{\circ}$, inciso I, da Lei n. 12.016/2009) ${ }^{84}$.

Em segundo lugar, Mancuso apresenta um argumento de ordem prática: o efetivo acesso à justiça não é garantido apenas com um enunciado normativo, sendo necessária uma verdadeira política pública nesse campo, que dê os meios para que o Judiciário desempenhe com eficiência suas funções, citando a experiência com os Juizados Especiais, que se mostrou exitosa na implantação, tanto que proliferou em espécies: iniciou-se com os Juizados Estaduais (Lei n. 9.099/95), em seguida os Federais (Lei n. 10.259/2001), os de violência doméstica (art. 29 da Lei n. 11.340/2006), e, por fim, os da Fazenda Pública (Lei n. $12.153 / 2009)^{85}$.

Contudo, chama a atenção que a própria eficiência da Justiça nesses casos pode ser um fator de sua sobrecarga e de inversão dos papéis do Estado. Em especial no caso da Administração Pública, a existência de um mecanismo absolutamente incondicionado e de facilidade de acesso pode "dissuadir as partes a se comporem entre si ou a procurarem outros meios e modos de resolução, assim preferindo judicializar desde logo as suas pendências" ${ }^{86}$.

Poder-se-ia dizer, portanto, que determinada manifestações de litigiosidade excessiva, especialmente em se tratando da conduta da Administração Pública, militariam contra essa leitura racional do acesso à justiça, ao permitir a judicialização (e consequente

\footnotetext{
${ }^{83}$ MANCUSO, Rodolfo de Camargo. O direito à tutela jurisdicional, p. 146.

${ }^{84}$ MANCUSO, Rodolfo de Camargo. O direito à tutela jurisdicional, p. 146.

${ }^{85}$ MANCUSO, Rodolfo de Camargo. O direito à tutela jurisdicional, p. 147.

${ }^{86}$ MANCUSO, Rodolfo de Camargo. O direito à tutela jurisdicional, p. 148.
} 
atraso) de direitos que poderiam ser reconhecidos independentemente de ação judicial. Encontramos, na Administração Pública, condutas de resistência ou demandismo que não se coadunam com essa perspectiva.

Agregando-se à reformulação do conteúdo do art. $5^{\circ}$, inciso $\mathrm{XXXV}$, da Constituição Federal, Rodolfo Mancuso aponta para a inviabilidade da sustentação do "monopólio estatal de distribuição de Justiça", observando-se a tendência de desjudicializar os conflitos e estabelecer um ambiente de "jurisdição compartilhada", apoiada na "efetiva aptidão e idoneidade de uma dada instância, órgão ou agência, no setor público ou privado, para prevenir ou dirimir conflitos em modo justo e num tempo razoável" ${ }^{87}$.

É paradigma que está em consonância com o proposto na terceira onda de Cappelletti e Garth, ou seja, de expansão das formas de manifestação do acesso à justiça. Em acréscimo, as ideias do autor também relêm a inafastabilidade da jurisdição estatal e do direito de ação, especialmente no tocante a uma de suas condições, o interesse de agir, que, para Mancuso, poderia não estar presente quando "não esgotadas as vias suasórias ou enquanto não tentada a prevenção/resolução do conflito por outros meios, auto ou heterocompositivos" ${ }^{\prime \prime 8}$.

Algo parecido já foi proposto por Frank Sander na já mencionada Pound Conference. Guardadas as devidas particularidades de cada sistema, na mencionada conferência, o autor preocupa-se com a extensão da garantia constitucional de julgamento das causas por um júri ${ }^{89}$ e como isso possivelmente limitaria o uso de mecanismos alternativos de solução de conflitos. Para o autor, é possível conviver com tal restrição e, ao mesmo tempo, atingir bons resultados. Contudo, o autor questiona, nos idos da década de 70 , se a exigência de um julgamento por júri ainda faz sentido na maioria dos casos ordinários, especialmente se forem levados em consideração o tempo e o custo expendidos. Propõe, em consequência, que se discuta onde faz sentido ou não haver júri e, com isso, seja em última instância feita uma emenda constitucional ${ }^{90}$.

\footnotetext{
${ }^{87}$ MANCUSO, Rodolfo de Camargo. O direito à tutela jurisdicional, p. 148-149.

${ }^{88}$ MANCUSO, Rodolfo de Camargo. Acesso à justiça: condicionantes legítimas e ilegítimas. São Paulo: RT, 2011, p. 341.

${ }^{89}$ Emenda n. 7 à Constituição dos Estados Unidos da América: Nos processos de direito consuetudinário, quando o valor da causa exceder vinte dólares, será garantido o direito de julgamento por júri, cuja decisão não poderá ser revista por qualquer tribunal dos Estados Unidos senão de acordo com as regras do direito costumeiro.

${ }^{90}$ SANDER, Frank E. A. Varieties of Dispute Processing. LEVIN, Leo A.; WHEELER, Russell R (edit.). The Pound Conference: Perspectives on Justice in the future. St. Paul, MN: West Publishing, 1979, p. 6587 , p. 86.
} 
Contudo, ressalva o autor que essa operação não significa afastar o papel das Cortes, pelo contrário, reforçá-lo nas atividades para as quais elas são mais adequadas, evitando que sejam açodadas e paralisadas com casos que não requerem suas capacidades. Entre os casos em que a atividade judicial é necessária, destaca a proteção aos menos favorecidos, aqui entendendo aqueles grupos que refletem as minorias qualitativas ${ }^{91}$. Assim, uma visão que relacione o interesse de agir do direito de ação com sua subsidiariedade e com o uso de instrumentos mais adequados deve atentar à legitimidade e efetividade desses outros mecanismos e à necessidade de respostas céleres e, muitas vezes, de necessidade de acesso direito ao Judiciário, sob pena sim de configurar óbice ilegítimo $^{92}$.

Essa visão tem, ainda, um fundamento de ordem técnico-jurídica, que é o reconhecimento de que a sentença de mérito nem sempre é a via mais adequada de solucionar o conflito ante certas especificidades do caso concreto. Mancuso cita como exemplo o conflito multiplexo, que envolve crises de natureza diversa, de natureza socioeconômica, as quais não conseguem ser devidamente atendidas pelo processo judicial $^{93}$. De fato, o recorte dado pelo processo judicial e pela sentença de mérito é reducionista, não embarca, em regra, elementos não jurídicos. Poder-se-ia citar como exemplo um conflito familiar de raízes profundas que se manifesta em diversas lides (separação judicial, guarda de filhos, execuções de alimentos que se dilatam no tempo, sucessivas revisionais de alimentos, busca e apreensão de menor, etc.). A existência de filhos pode fazer com que a relação se prolongue no tempo. Fernanda Tartuce chama a atenção para a vantagem da utilização da via consensual nesses casos, em detrimento da

${ }^{91}$ SANDER, Frank E. A. Varieties of Dispute Processing. LEVIN, Leo A.; WHEELER, Russell R (edit.). The Pound Conference: Perspectives on Justice in the future. St. Paul, MN: West Publishing, 1979, p. 6587 , p. 85.

92 Vale lembrar que uma das tentativas em nosso direito de condicionar o direito de ação à prévia tentativa de composição consensual foi a inserção do art. 625-D na Consolidação das Leis Trabalhistas (CLT) pela Lei $n$. 9.958/200, que assim previu: “Qualquer demanda de natureza trabalhista será submetida à Comissão de Conciliação Prévia se, na localidade da prestação de serviços, houver sido instituída a Comissão no âmbito da empresa ou do sindicato da categoria". No âmbito do STF, tramitam em conjunto as ADIs n. 2139 e 2160 , que têm em seu objeto, entre outros, o mencionado dispositivo. Ainda que não tenham sido julgadas definitivamente, o Tribunal já decidiu pela concessão de medida liminar dando ao dispositivo interpretação conforme a Constituição, suspendendo a exigibilidade de submissão prévia do litígio à Comissão de Conciliação, por entender que "A Constituição Federal em vigor, ao contrário da pretérita, é exaustiva quanto às situações jurídicas passíveis de ensejar, antes do ingresso em juízo, o esgotamento da fase administrativa, alcançando, na jurisdição cível-trabalhista, apenas o dissídio coletivo" (BRASIL. Supremo Tribunal Federal. Ação Direta de Inconstitucionalidade Medida Cautelar n. 2.139-DF. Órgão Julgador: Tribunal Pleno. Relator para o acórdão: Min. Marco Aurélio. J. em: 13/05/2009. DJe em: 22/10/2009; BRASIL. Supremo Tribunal Federal. Ação Direta de Inconstitucionalidade Medida Cautelar n. 2.160-DF. Órgão Julgador: Tribunal Pleno. Relator para o acórdão: Min. Marco Aurélio. J. em: 13/05/2009. DJe em: 22/10/2009).

${ }^{93}$ MANCUSO, Rodolfo de Camargo. O direito à tutela jurisdicional, p. 149. 
imposição de uma decisão por terceiro, pois envolvem elementos não jurídicos como os vínculos efetivos em questão, aos quais a resposta judicial não é capaz de atender ${ }^{94}$.

\subsubsection{Meios alternativos de solução de conflito como forma de expansão do} acesso à justiça: algumas polemizações

Como visto, o fomento de meios alternativos de solução de conflitos está em consonância com a terceira onde renovatório de acesso à justiça, bem como com compreensões atuais sobre a garantia. Contudo, tal não se dá sem certa controvérsia.

a Resolução n. 125/2010, do CNJ, a qual procurou conferir maior regularidade à mediação e à composição, traz pontos que devem ser verificados, e é positiva quanto à expansão do acesso à justiça por formas alternativas. Em sua justificativa (ou "Considerandos"), a Resolução indica:

\footnotetext{
CONSIDERANDO que o direito de acesso à Justiça, previsto no art. $5^{\circ}, \mathrm{XXXV}$, da Constituição Federal além da vertente formal perante os órgãos judiciários, implica acesso à ordem jurídica justa;

CONSIDERANDO que, por isso, cabe ao Judiciário estabelecer política pública de tratamento adequado dos problemas jurídicos e dos conflitos de interesses, que ocorrem em larga e crescente escala na sociedade, de forma a organizar, em âmbito nacional, não somente os serviços prestados nos processos judiciais, como também os que possam sêlo mediante outros mecanismos de solução de conflitos, em especial dos consensuais, como a mediação e a conciliação;

CONSIDERANDO a necessidade de se consolidar uma política pública permanente de incentivo e aperfeiçoamento dos mecanismos consensuais de solução de litígios;"
}

Percebemos que o norte da criação da Resolução foi exatamente a identificação do acesso à Justiça, conforme previsão constitucional, como "acesso à ordem jurídica justa", que em seguida é considerada como um dever do Estado em organizar tal acesso, inclusive por meios alternativos que igualmente forneçam tratamento adequado aos problemas jurídicos. Nessa concepção, o acesso à justiça ganha contornos estendidos, porém permanece o dever estatal de organizar e viabilizar tais funções.

Frank Sander também anunciava, nesse mesmo sentido, que, como a utilização de múltiplas vias de tratamento de conflitos significa, possivelmente, a instauração de instâncias mais adequadas de tratamento de conflitos, melhorando a qualidade da prestação de justiça e fornecendo mais meios de acesso à justiça, esses desenvolvimentos

\footnotetext{
94 TARTUCE, Fernanda. Mediação nos conflitos civis, cit., p. 283.
} 
vão não apenas melhorar e diversificar o tratamento de conflitos que já vão à Justiça como também dar abertura a conflitos que antes remanesciam adormecidos ${ }^{95}$.

Por outro lado, Kim Economides, pesquisador que trabalhou por muito tempo com Mauro Cappelletti, expõe um ponto interessante sobre o tema. Analisando as reformas da "terceira onda", o autor expõe a sua outra face: segundo ele, em muitos países da Europa Ocidental, essas reformas não representam um desejo de valorizar a cidadania nem uma reação a uma crise de confiança nos ideais profissionais, apesar de essas questões também estarem presentes. O principal objetivo é a redução dos custos da oferta de serviços jurídicos. Em suas palavras,

[a]s tendências atuais em direção a serviços jurídicos alternativos, justiça informal, resolução alternativa de conflitos (alternative dispute resolution - ADR) e acertos condicionais de honorários devem ser vistas como tentativas de desviar, reduzir ou distribuir os custos de casos legais onerosos, através da experimentação de novos meios de processamento, administração e financiamento de disputas. Qualquer melhoria subsequente do acesso dos cidadãos (ou de legitimidade política/profissional) é um efeito colateral, positivo, mas secundário. Se o objetivo primordial das reformas de acesso for, verdadeiramente, reduzir o ônus financeiro do Estado, será que estas reformas estão, no final, condenadas ao fracasso ou são irrelevantes para a busca de concepções mais profundas (ou mesmo mais pragmáticas) de justiça? (grifo nosso $)^{96}$

O trecho revela certo receio com a inclusão das ADRs no sistema de justiça ser vista como algo que efetivamente promova "acesso à justiça" como objetivo inicial.

Mais à frente, o autor afirma que as reformas que acompanham a terceira onda não devem ser necessariamente equiparadas a acesso à justiça, pois significam apenas acesso à paz. O receio do autor é

serem oferecidas aos cidadãos soluções pacíficas, possivelmente até soluções com as quais possam ficar extremamente contentes e felizes, que, no entanto, permanecem aquém do resultado passível de ser obtido caso os direitos legais fossem exercidos por intermédio do sistema judiciário formal. Há, portanto, um perigo real nessa ubíqua tendência para o informalismo judicial, atualmente em voga, de se negar muito dos valores, da importância e da significação histórica do formalismo da justiça" "97.

95 SANDER, Frank E. A. Varieties of Dispute Processing. LEVIN, Leo A.; WHEELER, Russell R (edit.). The Pound Conference: Perspectives on Justice in the future. St. Paul, MN: West Publishing, 1979, p. 6587 , p. 65.

96 ECONOMIDES, Kim. Lendo as ondas do "Movimento de Acesso à Justiça": epistemologia versus metodologia? PANDOLFI, Dulce... [et. al]. Cidadania, justiça e violência. Rio de Janeiro: Ed. Fundação Getulio Vargas, 1999, p. 61-76, p. 70.

97 ECONOMIDES, Kim. Lendo as ondas do "Movimento de Acesso à Justiça": epistemologia versus metodologia? PANDOLFI, Dulce... [et. al]. Cidadania, justiça e violência. Rio de Janeiro: Ed. Fundação Getulio Vargas, 1999, p. 61-76, p. 71-72. 
A observação de Kim Economides é pertinente, na medida em que revela o risco de, por meio dos meios alternativos de solução de conflitos, independentemente da percepção dos cidadãos, lhes ser oferecida uma solução de conflitos de qualidade inferior ou facilitar a violação de direitos assegurados pelo Estado, ou, ainda, impedir o progresso do reconhecimento de direitos pela via da justiça formal.

Semelhante objeção, talvez mais contundente, é feita por Owen Fiss:

Parties might settle while leaving justice undone. The settlement of a school suit might secure the peace, but not racial equality. Although the partier are prepared to live under the terms they bargained for, and although such peacefull coexistence may be a necessary precondition of justice, and itself a state of affairs to be valued, it is not justice itself. To settle for something means to accept less than some ideal ${ }^{98}$.

De fato, a discussão em torno da oposição entre meios alternativos e justiça formal emerge sempre quando há o risco de direitos serem negados ou terem seu desenvolvimento restringido por não serem submetidos ao sistema formal de justiça. Ou, ainda, quando objetivos de políticas públicas específicas possam ser frustrados.

Exemplo disso é a discussão em torno da utilização de mediação ou conciliação nos casos envolvendo violência doméstica. Com a edição da Lei n. 9.099/95, que objetivou desformalizar a justiça e fomentar a resolução consensual de conflitos, inclusive no âmbito penal, infrações penais de menor potencial ofensivo passaram a ser passíveis de composição civil de danos ou de transação penal.

Os segmentos da sociedade ligados à proteção dos direitos da mulher e coibição da violência doméstica viam nessa possibilidade uma forma de dificultar ou até impedir o reconhecimento pela justiça formal da realidade que muitas mulheres brasileiras enfrentavam no seu ambiente doméstico, até então invisíveis ou secundarizadas pelo sistema penal. A maior crítica que se pode fazer é que a Lei n. 9.099 surgiu em um momento em que se ignoravam os pequenos crimes contras as mulheres ocorridos no âmbito doméstico, tidos como questão privada do casal ou da família, na qual o Estado na deveria intervir. A possibilidade de resolução "pacífica" de tais questões impediria que o problema da violência doméstica fosse reconhecido e coibido pela justiça formal, independentemente da gravidade abstrata do crime em questão. A manutenção dessa

\footnotetext{
${ }^{98}$ FISS, Owen. Against the settlement, cit. p. 1085-1086. Tradução livre: “as partes podem entrar em acordo e ao mesmo tempo deixarem de fazer justiça. $\mathrm{O}$ acordo em uma ação contra uma escola pode assegurar a paz, mas não a igualdade racial. Mesmo que as partes estejam preparadas para viver sob os termos que negociaram, e mesmo que essa coexistência pacífica possa ser condição necessária da justiça, e ser em si mesma um estado das coisas a ser valorizado, não é justiça. Entrar em acordo significa aceitar menos que o ideal".
} 
realidade significaria a violação de direitos de uma minoria qualitativa, as mulheres que sofrem violência doméstica ${ }^{99}$.

Dessa forma, a política de coibição da violência doméstica teve que passar pela revisão da Lei n. 9.099/95. A Lei n. 11.340/2006 (popularmente conhecida como "Lei Maria da Penha") cria mecanismos para coibir a violência doméstica e familiar contra a mulher, entre eles a criação de Juizados de Violência Doméstica e Familiar contra a Mulher, e excetua expressamente os crimes envolvendo violência doméstica ou familiar do âmbito da Lei n. 9.099/95 (art. 41). A jurisprudência imediatamente passou a interpretar a exceção como a impossibilidade de aplicação dos mecanismos despenalizadores (incluindo a transação penal e a composição civil) aos crimes de violência doméstica, o que foi confirmado e expandido pelo Supremo Tribunal Federal, que afirmou a completa inaplicabilidade da Lei n. 9.009/95 a tais situações ${ }^{100}$.

Assim, não se via realização da justiça em acordos feitos em situações de violência doméstica, pelo contrário, motivo pelo qual tal possibilidade foi vetada.

Paulo Eduardo Alves da Silva entende que o argumento dos autores que se pronunciam contra ver nos meios consensuais uma forma de justiça faz sentido: em sistemas como o brasileiro, em que a existência de justiça está condicionada à lei, os mecanismos de ADR não teriam mesmo a capacidade de promover justiça ${ }^{101}$.

Esse debate poderia levar a caminhos mais filosóficos, sobre o que é a justiça em dado sistema, e como promovê-la. Mas, para os fins desse trabalho, é suficiente ter uma concepção mais modesta de acesso à justiça enquanto acesso a uma composição adequada de conflitos, com realização de interesses segundo algum critério de justiça, que pode ser definido pelas partes, e que não precisa corresponder ao "ideal" ou ao critério legal (ver a respeito no item 3.1 ).

Dentro dessa concepção, o problema, ao que parece, seria enxergar na justiça formal e na justiça consensual dois pólos de oposição.

\footnotetext{
${ }^{99}$ Cf. PORTO, Pedro Rui da Fontoura. Violência doméstica e familiar contra a mulher: Lei n. 11.340/06 análise crítica e sistêmica. Porto Alegre: Livraria do Advogado, 2007, p. 38-39.

${ }^{100}$ Cf. BRASIL. Supremo Tribunal Federal. Ação Direta de Constitucionalidade n. 19. Órgão Julgador: Tribunal Pleno. Relator: Min. Marco Aurélio. J. em: 09.02.2012; BRASIL. Supremo Tribunal Federal. Ação Direita de Inconstitucionalidade n. 4.424. Órgão Julgador: Tribunal Pleno. Relator: Min. Marco Aurélio. J. em: 09.02.2012)

${ }^{101}$ SILVA, Paulo Eduardo Alves da. Solução de controvérsias: métodos adequados para resultados possíveis e métodos possíveis para resultados adequados. SALLES, Carlos Alberto; LORENCINI, Marco Antônio Garcia. SILVA, Paulo Eduardo Alves da. Negociação, mediação e arbitragem: curso básico para programas de graduação em Direito. São Paulo: Método, 2012, p. 1-26, p. 7.
} 
Retomando as observações já expendidas na Pound Conference por Frank Sander, a justiça formal, ou os meios adjudicatórios, não são substituídos pela justiça informal ou os meios consensuais. Está correta a inserção de formas diversas da adjudicação na noção de acesso à justiça (e na compreensão atual da garantia). Contudo, da mesma forma que se reconhece a inadequação da justiça tradicional para resolução de certos conflitos, os meios consensuais também apresentam suas "faixas de insindicabilidade", em que sua utilização é inadequada e incapaz de conferir a melhor justiça possível. O caso de proteção de minorias que não têm seus direitos consolidados é típico.

Nossa conclusão, neste ponto, é a revelação de que o acesso à justiça, como acesso à ordem jurídica justa - conforme preconizado pelo $\mathrm{CNJ}$-, deve considerar o aumento da litigiosidade como aspecto que exige o crescimento das formas de solução das controvérsias - formas essas judiciais ou extrajudiciais. Os meios alternativos, ao mesmo tempo que contêm a proliferação dos processos judiciais diante de seu caráter informal de distribuição de justiça, precisam se engajar como formas disponíveis aos jurisdicionados, contanto que, mais uma vez, sejam adequadas e preservem a adjudicação estatal para aquilo que se notar necessário.

\subsubsection{Essa concepção de acesso à justiça demanda a reformulação do conceito}

\section{de jurisdição?}

Carlos Alberto Salles vislumbra a necessidade de se reformular também o conceito de jurisdição ante o advento de novas formas hetero e autocompositivas de conflitos ${ }^{102}$, nem sempre com a preferência da via adjudicatória estatal.

Visitando a literatura mais tradicional sobre o tema, vemos que o a jurisdição é considerada, ao lado da legislação, uma função do Estado, ao cargo da qual fica a pacificação através da resolução de conflitos entre os sujeitos, como fica claro no seguinte trecho de Grinover, Dinamarco e Cintra:

\footnotetext{
“Com a segunda ordem de atividades jurídicas, consistente na jurisdição, cuida o Estado de buscar a realização prática daquelas normas em caso de conflito entre as pessoas declarando, segundo o modelo contido nelas, qual é o preceito pertinente ao caso concreto (processo de conhecimento) e desenvolvendo medidas para que este preceito seja realmente efetivado (processo de execução). Nesse quadro, a jurisdição é
}

${ }^{102}$ SALLES, Carlos Alberto de. A arbitragem na solução de controvérsias contratuais da Administração Pública, cit., p. 129-130. 
considerada uma longa manus da legislação, no sentido de que ela tem, entre outras finalidades, a de assegurar a prevalência do direito positivo do país" ${ }^{\text {"103 }}$.

Ademais, sustentam também que a jurisdição é monopólio do Estado, conforme o seguinte trecho: “À atividade mediante a qual os juízes estatais examinam as pretensões e resolvem os conflitos dá-se o nome de jurisdição" ${ }^{104}$ (grifo nosso).

Apontam, ainda, que, além de função, jurisdição é poder e atividade: "Como poder, é manifestação do poder estatal, conceituado como capacidade de decidir imperativamente e impor decisões.(....) E como atividade, ela é o complexo de atos do juiz no processo, exercendo o poder e cumprindo a função que a lei lhe comete"105 (grifo nosso)".

Dialogando com essa doutrina, Salles propõe que, para as finalidades de abarcar novos ambientes de tomadas de decisões imperativas e novas instâncias de decisão, seria mais adequado limitar o conceito de jurisdição a "poder de decidir imperativamente, isto é, com capacidade de gerar cumprimento de suas decisões"106.

Preocupa-se o autor principalmente em albergar no conceito a arbitragem privada, pois a partir redação do artigo 31 da Lei n. 9.307/94 (Lei de Arbitragem), não é possível negar a jurisdicionalidade desse meio de composição de conflitos: "A sentença arbitral produz, entre as partes e seus sucessores, os mesmos efeitos da sentença proferida pelos órgãos do Poder Judiciário e, sendo condenatória, constitui título executivo".

Segundo o autor, conceber a jurisdição de forma mais ampla, considerando apenas o "poder", torna mais fácil o acolhimento de meios não estatais sob o conceito de jurisdição. Isso porque os elementos função e a atividade são mais facilmente observáveis no Poder Judiciário. "Função" porque solucionar conflitos é normalmente concebido em termos de monopólio. "Atividade" porque é mais facilmente concebida naquela desenvolvida pelos juízes em "moldes permanentes"107.

Por outro lado, concorda o autor com a doutrina mais tradicional ao conceber como núcleo da jurisdição "o poder de decidir imperativamente controvérsias”. Considerando

103 CINTRA, Antonio Carlos de Araújo; GRINOVER, Ada Pellegrini; DINAMARCO, Cândido Rangel. Teoria geral do Processo. 20. ed. São Paulo: Malheiros, 2004, p. 38.

104 CINTRA, Antonio Carlos de Araújo; GRINOVER, Ada Pellegrini; DINAMARCO, Cândido Rangel. Teoria geral do Processo, p. 23.

105 CINTRA, Antonio Carlos de Araújo; GRINOVER, Ada Pellegrini; DINAMARCO, Cândido Rangel. Teoria geral do Processo, p. 131.

${ }^{106}$ SALLES, Carlos Alberto de. A arbitragem na solução de controvérsias contratuais da Administração Pública, cit., p. 130.

${ }^{107}$ SALLES, Carlos Alberto de. A arbitragem na solução de controvérsias contratuais da Administração Pública, cit., p. 130-131. 
esse núcleo, é possível reconhecer jurisdicionalidade não só aos juízes estatais integrantes do Judiciário, mas também aos árbitros e órgãos administrativos que decidem de forma semelhante, como o CADE e os tribunais de contas, ainda que, nestes últimos casos, a decisão não seja tomada em caráter definitivo, sendo controversa a atribuição da qualidade de imperatividade ${ }^{108}$.

Já para Fernanda Tartuce, a nota característica da jurisdição, a fim de adequar seu conceito à nova realidade, é a atividade, pois esta pode ser realizada em diversos âmbitos, inclusive não estatais (como no caso da arbitragem) e seu objeto pode ser ampliado, para, além das crises jurídicas, abarcar o "correto encaminhamento de interesses relevantes", ou seja, o exercício da jurisdição voluntária ${ }^{109}$.

Para Mancuso, o ambiente que se pretende estimular pela Resolução n. 125/2010 do CNJ,que institui a Política Judiciária Nacional de tratamento de conflitos é de jurisdição compartilhada ${ }^{110}$. Para o autor, embora o termo esteja normalmente ligado à Justiça estatal, não apresente base homogênea, sendo palavra polissêmica e plurívoca, empregada em diferentes contextos com diversas finalidades ${ }^{111}$ :

é visível o crescimento de instâncias, órgãos e agentes parajurisdicionais, voltados à prevenção e/ou à resolução consensual dos conflitos, levando ao gradual reconhecimento de que a jurisdição não é apanágio exclusivo do Estado, mas, ao contrário, assiste a todo agente, órgão e instância capaz de prevenir ou resolver, em tempo hábil, uma crise iminente ou já instalada. É dizer, sem meias-palavras: cumpre reconhecer que dentre nós já se instalou um ambiente de jurisdição compartilhada" ${ }^{\text {112 }}$.

Contudo, deve ser esclarecido que a Política em questão não se volta ao tratamento adjudicatório dos conflitos, mas sim ao consensual. Pode-se argumentar que os meios consensuais não se enquadram no conceito de "jurisdição", haja vista que esta é "a manifestação de poder estatal, conceituado como capacidade de decidir imperativamente e impor decisões", em que "o Estado substitui, com uma atividade sua, as atividades daqueles que estão envolvidos no conflito trazido à apreciação"113. Os meios consensuais podem ser vistos como uma forma de justiça (justiça consensual), contudo, a solução do

\footnotetext{
108 SALLES, Carlos Alberto de. A arbitragem na solução de controvérsias contratuais da Administração Pública, p. 133.

109 TARTUCE, Fernanda. Mediação nos conflitos civis. São Paulo: Método, 2008, p. 84.

${ }^{110}$ MANCUSO, Rodolfo de Camargo. O direito à tutela jurisdicional, p. 151.

${ }^{111}$ MANCUSO, Rodolfo de Camargo. Acesso à justiça: condicionantes legítimas e ilegítimas. São Paulo: RT, 2011, p. 337.

${ }^{112}$ MANCUSO, Rodolfo de Camargo. Acesso à justiça: condicionantes legítimas e ilegítimas. São Paulo: RT, 2011, p. 336-337.

${ }^{113}$ CINTRA, Antonio Carlos de Araújo; GRINOVER, Ada Pellegrini; DINAMARCO, Cândido Rangel.

Teoria geral do Processo. 20. ed. São Paulo: Malheiros, 2004, p. 131-132.
} 
conflito não é imposta e nem advém do Estado, mas sim é construída a partir da condução dos próprios envolvidos a uma solução que se pretende rápida, eficaz e satisfatória ${ }^{114}$. Por isso, é inegável que se inserem num movimento de transformação das formas de distribuição de justiça. Não obstante, Salles entende que a ampla concepção de jurisdição, que melhor explica o momento atual de jurisdição compartilhada, abarcaria também a técnica de induzir as partes a uma solução de consenso ${ }^{115}$.

Sem pretender esgotar esse tema ou traçar um conceito definitivo e revisitado de jurisdição, é certo que o atual contexto tem impulsionado sua reformulação, esforço teórico que deverá ser sedimentado para melhor compreensão do ambiente de estímulo, fomento e gerenciamento de novas formas de composição de conflitos pelo Estado.

${ }^{114}$ Cf. TARTUCE, Fernanda. Mediação nos conflitos civis. São Paulo: Método, 2008, p. 208.

115 SALLES, Carlos Alberto de. A arbitragem na solução de controvérsias contratuais da Administração Pública, p. 133. 


\section{TRANSFORMAÇÕES NOS PARADIGMAS DO DIREITO ADMINISTRATIVO}

\subsection{Bases tradicionais do Direito Administrativo: supremacia e indisponibilidade do interesse público.}

Maria Sylvia Zanella Di Pietro nos explica que, na história do Direito Administrativo, este ramo de estudo é definido "conjunto de princípios que regem a Administração Pública”. Para a autora, não basta tal definição sem a compreensão do que de fato é a Administração Pública. Há, por outro lado, definições que contemplam o estudo da Administração Pública sob aspecto formal (manifestações do Poder Público decompostas em atos jurídico-administrativos dotados de autoexecutoriedade) ${ }^{116}$.

Para a autora, a definição baseada ainda é incompleta, pois a Administração Pública não é dotada apenas de atos autoexecutórios que impõem obrigações ao administrado, mas também de atos de reconhecimento de direitos, como a permissão, a licença, a autorização, às quais adicionamos os contratos firmados pela Administração em sentido amplo ${ }^{117}$.

Assim, a autora propõe uma definição de Direito Administrativo como

\footnotetext{
“o ramo do Direito Público que tem por objeto os órgãos, agentes e pessoas jurídicas administrativas que integram a Administração Pública, a atividade jurídica não contenciosa que exerce e os bens de que se utiliza para a consecução de seus fins, de natureza pública" ${ }^{\prime 18}$.
}

O Direito Administrativo, portanto, contempla os entes que compõe a Administração Pública e sua atividade. A autora ainda esclarece que "Administração Pública", para tais fins, é considerada em sua função administrativa, excluindo-se a função política (nela compreendida a atividade de direção, de traçado das grandes diretrizes e de comando nas várias áreas de atuação), que é dividida entre Poder Executivo e Legislativo. Assim, a Administração não se confunde com o Poder Executivo, que tem função mais $\operatorname{ampla}^{119}$.

\footnotetext{
${ }^{116}$ DI PIETRO, Maria Sylvia Zanella. Direito Administrativo. 20. ed. São Paulo: Atlas, 2007, p. 42-43.

${ }^{117}$ DI PIETRO, Maria Sylvia Zanella. Direito Administrativo. 20. ed. São Paulo: Atlas, 2007, p. 43.

${ }^{118}$ DI PIETRO, Maria Sylvia Zanella. Direito Administrativo. 20. ed. São Paulo: Atlas, 2007, p. 43.

${ }^{119}$ DI PIETRO, Maria Sylvia Zanella. Direito Administrativo. 20. ed. São Paulo: Atlas, 2007, p. 49-50.
} 
É considerada, desta forma, a Administração em sentido estrito, que compreende tanto seu aspecto objetivo quanto subjetivo.

Em sentido objetivo, são incluídos as funções de fomento ("atividade administrativa de incentivo à iniciativa privada"), a polícia administrativa ("toda atividade de executar limitações impostas pela lei aos direitos individuais em favor do interesse público"), o serviço público ("atividade que a Administração Pública executa, direta ou indiretamente, para satisfazer à necessidade coletiva, sob regime jurídico predominantemente público"), e a intervenção ("regulamentação e fiscalização da atividade econômica de natureza privada") ${ }^{120}$.

Em sentido subjetivo, compreende a administração direta e indireta do Estado, que, em nosso direito positivo, pode ser identificada com precisão no art. $4^{\circ}$ do Decreto-Lei $n$. 200/67:

Art. $4^{\circ}$ A Administração Federal compreende:

I - A Administração Direta, que se constitui dos serviços integrados na estrutura administrativa da Presidência da República e dos Ministérios.

II - A Administração Indireta, que compreende as seguintes categorias de entidades, dotadas de personalidade jurídica própria:
a) Autarquias;
b) Emprêsas Públicas;
c) Sociedades de Economia Mista.
d) fundações públicas.

Existem outras definições de Direito Administrativo que abrangem figuras nãoestatais no âmbito desse ramo de estudo. A exemplo, Marçal Justen Filho conceitua este ramo do Direito como "conjunto de normas jurídica de direito público que disciplinam as atividades administrativas necessárias à realização dos direitos fundamentais e a organização e funcionamento das estruturas estatais e não estatais encarregadas de seu desempenho"121. São outras opções para a abordagem da matéria, que se direcionam, no caso do referido autor, para a noção estruturante do Direito Administrativo como promovedor - ou, ao menos, organizador - de políticas públicas. Contudo, esta dissertação e, especialmente, esse tópico se ocupam da atuação de estruturas estatais e do que determina e influencia a sua atuação. Desta forma, o Direito Administrativo é, em primeiro lugar, um recorte didático do estudo do direito positivo. Em segundo lugar, ganha dimensão de um conjunto de conhecimentos que gera uma visão particular sobre as situações compreendidas em seu objeto.

\footnotetext{
${ }^{120}$ DI PIETRO, Maria Sylvia Zanella. Direito Administrativo. 20. ed. São Paulo: Atlas, 2007, p. 50-51.
}

${ }^{121}$ JUSTEN FILHO, Marçal. Curso de Direito Administrativo. 6. ed. Belo Horizonte: Fórum, 2010, p. 65. 
Por mais que a construção de soluções normativas e explicações dogmáticas calcadas primordialmente (e muitas vezes exclusivamente) em princípios venham sendo criticadas $^{122}$, fato é que o Direito Administrativo no Brasil foi desenvolvido com base em alguns princípios fundantes, que ecoam através dos doutrinadores de diferentes épocas e aos quais são atribuídos sentidos diversos. Por estarmos tratando da influência desses elementos na prática do Direito Administrativo, a noção de princípio é adotada, dentre as tantas discussões que existem sobre o assunto, na sua concepção mais corriqueira, bem traduzida por Odete Medauar a partir das lições de Karl Larenz como "fórmulas nas quais estão contidos os pensamentos diretores do ordenamento, de uma disciplina legal ou de um instituto jurídico" ${ }^{\prime 23}$.

Os princípios naturalmente influenciam tanto as construções normativas e posicionamentos adotados pelos operadores do direito na execução das suas atribuições (juízes, membros do Ministério Público, advogados públicos) quanto o próprio estudo do direito e a construção de proposições dogmáticas para compreensão dos fenômenos e orientação das soluções pelos doutrinadores.

Para avaliar a possibilidade e os limites da solução consensual de conflitos pelos entes da Administração Pública, muitos estudos levam em consideração esses princípios contidos na tradição do Direito Administrativo, especialmente a supremacia do interesse público e a legalidade. O presente tópico tratará desses princípios e da sua influência no tema dos meios consensuais. Em seguida, tratará da introdução do princípio da eficiência no Direito Administrativo. Na sequência, introduzirá um tema que se apresenta não como um princípio, mas de um fenômeno que vem ocorrendo no Direito Administrativo, que é o da utilização de instrumentos consensuais em complemento à atuação administrativa que se baseia exclusivamente na autoridade.

A releitura dos princípios da legalidade e da supremacia do interesse público, a introdução do princípio da eficiência e o desenvolvimento de formas consensuais de atuação administrativa são temas importantes para compreender o cenário que favorece o uso de meios consensuais pela Administração.

\footnotetext{
122 "Vive-se hoje um ambiente de 'geleia geral' no direito público brasileiro, em que princípios vagos podem justificar qualquer decisão. (...) O profissional do Direito, ao construir soluções para os casos, tem um dever analítico. Não bastam as boas intenções, não basta intuição, não basta invocar e elogiar princípios; é preciso respeitar o espaço de cada instituição, comparar normas e opções, estudar causas e consequências, ponderar as vantagens e as desvantagens. Do contrário, viveremos no mundo da arbitrariedade, não do Direito" (SUNDFELD, Carlos Ari. Princípio é preguiça? Direito Administrativo para céticos. São Paulo: Malheiros, 2012, p. 60-61)..

${ }^{123}$ LARENZ, Karl. Derecho Justo (trad. Luiz Díez-Picaso). Madrid: Civitas, 1985, p. 14 apud MEDAUAR, Odete. Direito Administrativo Moderno. 16. ed. São Paulo: RT, 2012, p. 133.
} 


\subsubsection{Legalidade}

A doutrina clássica do Direito Administrativo tem como corolário o princípio da legalidade estrita, segundo o qual à Administração Pública só é permitido fazer o que a lei autoriza. A legalidade, ao lado da impessoalidade, moralidade, publicidade e eficiência, é princípio regente da atuação da Administração Pública, segundo o art. 37 da Constituição Federal. O sentido mais comum da legalidade administrativa pode ser representado pelo seguinte trecho de Maria Sylvia Zanella Di Pietro ${ }^{124}$ :

Segundo o princípio da legalidade, a Administração Pública só pode fazer o que a lei permite. (...) Em decorrência disso, a Administração Pública não pode, por simples ato administrativo, conceder direitos de qualquer espécie, criar obrigações ou impor vedações aos administrados; para tanto, ela depende de lei ${ }^{125}$.

De forma mais específica, Odete Medauar explica que a legalidade administrativa comporta gradações em seus sentidos operacionais. Segundo a autora, nosso ordenamento não adota noções mais estritas da legalidade, as quais seriam as máximas de que "a Administração Pública só pode realizar atos ou medidas que a lei ordena" e "somente são permitidos atos cujo conteúdo seja conforme a uma hipótese abstrata fixada explicitamente por norma legislativa", ainda que esta última acepção se manifeste por vezes no exercício do poder vinculado. Essas noções, se predominantes, engessariam a Administração Pública, dificultando a perseguição do interesse público ${ }^{126}$.

Para esta autora, predomina o sentido da legalidade administrativa como "habilitação legal" para adoção de atos e medidas, sentido esse que também apresenta gradações internas: por vezes, pode ser um vínculo estrito do conteúdo ou do ato, mas, na maioria delas, é simples norma de competência, que habilita algum agente à prática de um ato de conteúdo que não é definido na $\mathrm{lei}^{127}$. Há que se ter em conta, todavia, que as Constituições nos três níveis de governo contêm disposições de reserva de lei, segundo as quais determinadas matérias exigem disciplina legal expressa, como no caso da criação de tributos (art. 150, I, da Constituição Federal).

${ }^{124}$ DI PIETRO, Maria Sylvia Zanella. Direito Administrativo. 20. ed. São Paulo: Atlas, 2007, p. 59.

${ }^{125}$ DI PIETRO, Maria Sylvia Zanella. Direito Administrativo. 20. ed. São Paulo: Atlas, 2007, p. 59.

${ }^{126}$ MEDAUAR, Odete. Direito Administrativo Moderno. 16. ed. São Paulo: RT, 2012, p. 136.

${ }^{127}$ MEDAUAR, Odete. Direito Administrativo Moderno. 16. ed. São Paulo: RT, 2012, p. 137. 
Seguindo a ideia de habilitação legal, para Carlos Alberto de Salles, a funcionalidade do conceito de legalidade é delimitar o espaço da discricionariedade ou da liberdade da atuação administrativa, ou seja, até onde a conduta da Administração está submetida à disciplina normativa de que somente seria lícito realizar o que prescrito em lei - a chamada regra de "clausura do ordenamento" -, enquanto ao particular está permitido tudo o que a Lei não proíbe (legalidade civil). Segundo o autor, "de fato, o espaço da liberdade de atuação administrativa é circunscrito à lei, na forma de discricionariedade, não se estendendo àquela zona de possibilidades não reguladas pelo ordenamento jurídico" ${ }^{\text {"28 }}$.

Em compreensão semelhante, Celso Antonio Bandeira de Mello entende que a legalidade não exclui que a Administração crie a utilidade pública em nível infralegal e de forma concreta, o que se dá pela sua atuação discricionária. Contudo, a lei, ao regular abstratamente as situações, impõe ao administrador uma finalidade legal e dá limites, mas ao mesmo tempo confere espaço para que ele eleja a solução mais adequada ${ }^{129}$.

Essa é, tradicionalmente, a compreensão da legalidade administrativa, em oposição à legalidade aplicada ao particular, a quem seria permitido fazer tudo o que a lei não proíba. Tem assento na ideia de que a vontade do ente público se expressa pela própria lei, e que não haveria espaço para os seus representantes agirem para além dela.

Contudo, há uma corrente que entende que, com a promulgação da Constituição Federal de 1988 e sua reconhecida centralidade como fonte do direito, atingindo todas as suas áreas, muitos axiomas do Direito Administrativo devem ser revistos, inclusive a leitura tradicional da legalidade administrativa. Nesse sentido, Gustavo Binenbojm defende que a Constituição é fonte direta de legalidade administrativa, atuante como norma fundante da atuação da Administração Pública tanto nos casos de ausência de lei infraconstitucional específica para a prática de determinado ato administrativo quanto até mesmo nos casos em que a lei inferior contrarie a finalidade da norma constitucional. Esta atuação se deve a uma noção de proporcionalidade de aplicação do interesse veiculado pela Constituição Federal, de maneira que, ao se utilizar determinado princípio da Carta da República em desfavor de regras inferiores, o conflito entre norma constitucional e regra infraconstitucional, a lei específica pode ser afastada, no caso concreto, por uma aplicação direta da norma constitucional otimizada ao caso. Nessa concepção, pode-se cogitar

${ }^{128}$ SALLES, Carlos Alberto de. A arbitragem na solução de controvérsias contratuais da Administração Pública. Tese (livre-docência), São Paulo, Faculdade de Direito da Universidade de São Paulo, 2010, pl 171172.

${ }^{129}$ MELlo, Celso Antônio Bandeira de. Curso de Direito Administrativo. 31 ed. São Paulo: Malheiros, 2014 , p. 80. 
também da adoção de condutas pela Administração que não estejam disciplinadas em lei, mas que extraem seu fundamento diretamente da Constituição ${ }^{130}$. Em síntese, o autor pondera que:

\begin{abstract}
a atividade administrativa continua a realizar-se, via de regra, segundo a lei, quando esta for constitucional (atividade secundum legem), (b) mas pode encontrar fundamento direto na Constituição independentemente da lei (atividade praeter legem), ou, eventualmente, (c) legitimar-se perante o direito, ainda que contra a lei, porém com fulcro numa ponderação de legalidade com outros princípios constitucionais (atividade contra legem, mas com fundamento numa otimizada aplicação da Constituição) ${ }^{131}$
\end{abstract}

Esta nova visão sobre a legalidade administrativa altera diretamente o sentido da norma constitucional, a qual se sobrepõe como norma superior, mas também se aplica diretamente ao caso concreto, pela autoexecutoriedade de seu mandamento e efetiva aplicabilidade direta dos princípios constitucionais.

A compreensão desses sentidos da legalidade administrativa é importante porque repercute na discussão sobre a possibilidade ou não de adoção de meios consensuais independentemente de previsão legal específica.

\title{
2.1.2. Reformulação do princípio da supremacia do interesse público
}

O princípio da supremacia do interesse público é trazido tradicionalmente como uma forma de solução de conflito de opções na atuação administrativa: ao se ponderarem os interesses em conflito em determinada situação concreta, deve prevalecer a solução que priorize o bem de toda a coletividade. Celso Antonio Bandeira de Mello une a supremacia do interesse público com a condição de indisponibilidade de tais interesses, que são chancelados pelo denominado "poder de polícia administrativa", o qual permite que o Estado, de forma unilateral, regulamente a própria autonomia da vontade para que os efeitos dela decorrentes estejam de acordo com o interesse do Estado, representativo do todo social ${ }^{132}$.

Odete Medauar se contrapõe à ideia de que a supremacia do interesse público justifica as posições, e qualquer uma delas, adotadas pela Administração Pública, ainda

130 BINENBOJM, Gustavo. Um novo direito administrativo para o século XXI. Temas de Direito Administrativo e Constitucional. Rio de Janeiro: Renovar, 2008, p. 84.

132 BANDEIRA DE MELO, Celso Antonio. O conteúdo do regime jurídico-administrativo e seu valor metodológico. Revista de Direito Público n. 2. São Paulo: RT, 1967, p. 13-14. 
que arbitrárias, devendo ser ponderado nos casos concretos a solução que implique no mínimo de sacrifício aos interesses envolvidos. A autora assim escreve:

\begin{abstract}
vem sendo matizado pela ideia de que à Administração cabe realizar a ponderação dos interesses presentes numa determinada circunstância, para que não ocorra o sacrifício $a$ priori de nenhum interesse; o objetivo dessa função está na busca de compatibilidade ou conciliação de interesses, com a minimização de sacrifícios. Até os autores que se aferram a este princípio reconhecem a necessidade de sua 'reconstrução', de sua adequação à dinâmica social, de sua adaptação visando à harmonização dos interesses. $\mathrm{O}$ princípio da proporcionalidade também matiza o sentido absoluto do preceito, pois implica, entre outras decorrências, a busca da providência menos gravosa, na obtenção de um resultado ${ }^{133}$.
\end{abstract}

Ou seja, a supremacia do interesse público não pode determinar que um interesse privado simplesmente sucumba ante sua aparente contradição com um interesse da coletividade. Marçal Justen Filho adota posição semelhante no tocante à ponderação de interesses, até por reconhecer que existem uma pluralidade de "interesses públicos" "134, mas é extremamente garantista em relação a direitos subjetivos. Para o autor, há uma diferença: o direito subjetivo privado existe quando a um sujeito é atribuída a possibilidade de se exigir uma conduta específica. Já o interesse não envolve essa atribuição de um dever determinado. O "interesse público" só prevaleceria sobre um direito subjetivo se assim o ordenamento expressamente previsse ${ }^{135}$. Havendo pluralidade de interesses envolvidos a serem tutelados, e não podendo o "interesse público" se sobrepor a direitos subjetivos, estaria esvaziada de utilidade. Mesmo em casos em que interesses privados (e não direitos subjetivos) se contrapusessem a interesses públicos, "não se pode impor uma escolha prévia em favor do interesse dito público - senão quando evidenciar ser a decisão a mais conforme e adequada em face do conjunto da ordem jurídica" ${ }^{136}$.

De fato, a doutrina administrativista mais moderna vem questionando se (i) tal princípio é de fato um princípio democrático e (ii) se é um princípio operável e, portanto, útil para a tomada de decisões, ou se é apenas recurso retórico.

\footnotetext{
${ }^{133}$ MEDAUAR, Odete. Direito Administrativo Moderno. 16. ed. São Paulo: RT, 2012, p. 142.

134 JUSTEN FILHO, Marçal. Curso de Direito Administrativo. 9. ed. São Paulo: RT, 2013, p. 145.

135 JUSTEN FILHO, Marçal. Curso de Direito Administrativo. 9. ed. São Paulo: RT, 2013, p. 146.

${ }^{136}$ JUSTEN FILHO, Marçal. Curso de Direito Administrativo. 9. ed. São Paulo: RT, 2013, p. 148.
} 
Vale trazer os argumentos expostos por Gustavo Binenbojm no contundente artigo "Da supremacia do interesse público ao dever de proporcionalidade: um novo paradigma para o Direito Administrativo" $" 137$.

Para iniciar seu argumento, o autor ataca a versão mais corrente entre os administrativistas da própria criação do Direito Administrativo, segundo a qual esse ramo do Direito teria viés liberal e teria sido criado na França como uma forma de limitação do Poder outrora absoluto em favor dos direitos individuais. Teria, portanto, cunho garantístico $^{138}$.

O autor se esforça em demonstrar que, ao contrário do que se prega, o histórico das instituições jurídicas na França confirma que a criação do Direito Administrativo foi uma forma da administração se subtrair do esquema geral de separação dos poderes e criar uma dogmática própria que possibilitasse a reprodução do poder vigente ${ }^{139}$.

O Direito Administrativo não teria surgido de uma submissão da administração à vontade do legislador (representante do povo). A criação do Conseil d'Etát, com jurisdição administrativa própria, possibilitou à administração subtrair-se tanto do controle do legislador quando do Judiciário. Foi o órgão da própria administração que criou toda a dogmática que favoreceu uma reprodução autoritária do poder da administração. Trata-se de paradoxo original do Direito Administrativo, que deveria conter a autoridade, mas torna-se autoritário por meio das instituições por ele próprio criadas ${ }^{140}$.

Desse "pecado original" surgem muitos conceitos, princípios e paradigmas de Direito Administrativo que hoje se encontram em crise, por não mais atenderem às expectativas da sociedade em relação à Administração e por terem se revelado ao longo da história como incapazes de acompanhar as evoluções na compreensão do Direito. Dentre os paradigmas que passar por uma crise está aquele que é objeto de discussão do texto: o da supremacia do interesse público ${ }^{141}$.

O vetor básico da crise desse paradigma é a constitucionalização do Direito, que desloca o eixo de atividade administrativa da lei infraconstitucional para a Constituição. Nesse contexto, o que se entendia "interesse público", antes supremo, depara-se com uma

${ }^{137}$ BINENBOJIN, Gustavo. Da supremacia do interesse público ao dever de proporcionalidade: Um novo paradigma para o Direito Administrativo. Revista de Direito da Procuradoria Geral, Rio de Janeiro, n. 59, 2005, p. 49-82.

${ }^{138}$ BINENBOJIN, Gustavo. Da supremacia do interesse público ao dever de proporcionalidade, p. 49-50.

${ }^{139}$ BINENBOJIN, Gustavo. Da supremacia do interesse público ao dever de proporcionalidade, p. 51.

${ }^{140}$ BINENBOJIN, Gustavo. Da supremacia do interesse público ao dever de proporcionalidade, p. 51-52.

${ }^{141}$ BINENBOJIN, Gustavo. Da supremacia do interesse público ao dever de proporcionalidade, p. 53-54. 
série de direitos fundamentais e outros valores e interesses metaindividuais que também passam a receber proteção jurídica ${ }^{142}$.

Assim, não mais se justificaria o princípio como regra de solução de conflitos: sempre que houver choque entre o público e o particular, resolve-se dando prevalência àquele ${ }^{143}$. Isso porque que as construções sobre a supremacia do interesse público são frágeis e contraditórias: tal ideia não se alinha à atual compreensão dos princípios, que pressupõe ponderação nos casos concretos em que houver colisão. Existe incompatibilidade entre a ideia de supremacia (absoluta) e de ponderação (relativização) ${ }^{144}$. Não há, portanto, uma definição apriorística para o interesse público como algo que deva prevalecer aprioristicamente: sua construção acontece caso a caso.

Por outro lado, o princípio da supremacia do interesse público tem, de fato, sua validade enquanto "pensamento diretor" do ordenamento jurídico e como recurso que reforça o caráter publicista do Direito Administrativo e a necessidade de dissociar a finalidade do Estado dos interesses dos próprios governantes e de outros entes privados. Contudo, em uma acepção mais concreta e moderna de princípio, uma parcela da doutrina administrativista vem apontando a dificuldade de operar com a noção de "supremacia", que se barraria na existência de direitos fundamentais e na própria indefinição apriorística de interesse público ${ }^{145}$.

Juliana Bonacorsi de Palma destaca a dificuldade teórica de sustentar o princípio da supremacia do interesse público, pois é difícil extrair de uma sociedade plural e fragmentada um único conceito de interesse público que deva prevalecer a priori em qualquer caso, de forma que "[t]odos os interesses constatados no caso concreto devem ser objeto de ponderação para que a Administração Pública determine, racionalmente e de forma motivada, o interesse que deve prevalecer em detrimento dos demais"146.

Há situações em que essa ponderação já foi feita previamente pelo ordenamento, em forma clara de regra, favorecendo, inclusive, o interesse coletivo, como é o caso da desapropriação, autorizada para destinação pública pelo texto constitucional, em contraposição ao interesse privado na propriedade. Por outro lado, o ordenamento por vezes limita o interesse coletivo, com se diz, por exemplo, das limitações às interceptações

\footnotetext{
${ }^{142}$ BINENBOJIN, Gustavo. Da supremacia do interesse público ao dever de proporcionalidade, p. 59-60.

${ }^{143}$ BINENBOJIN, Gustavo. Da supremacia do interesse público ao dever de proporcionalidade, p. 58-63.

${ }^{144}$ BINENBOJIN, Gustavo. Da supremacia do interesse público ao dever de proporcionalidade, p. 36-67.

145 JUSTEN FILHO, Marçal. Curso de Direito Administrativo. 7. ed. Belo Horizonte: Fórum, 2011, p. 114115.

${ }^{146}$ PALMA, Juliana Bonacorsi de. Atuação administrativa consensual, cit., p. 152.
} 
telefônicas na investigação de crimes, em favor do interesse privado e da proteção aos direitos individuais. Contudo, há situações indeterminadas, e linhas mais tênues entre o que é interesse coletivo e o que é privado, e qual deve prevalecer no caso - o que só pode ser feito com um juízo de ponderação in casu, sem posicionamento apriorístico.

Podemos acrescentar que, estando a Administração em conflito com um particular, o interesse público não se identifica necessariamente com a posição adotada pela Administração Pública, com o que seus representantes declaram ser seu interesse. $\mathrm{O}$ interesse público é construído a partir da ponderação dos interesses em jogo, e não a partir da declaração da Administração Pública.

Concluindo que a operação da ideia de supremacia apriorística do interesse público, enquanto princípio gerador de alternativas de decisão, é questionável devido à necessidade de ponderação de todos os interesses envolvidos, mas, por outro lado, há parcela da doutrina que entende seu valor como um reforço publicista, é necessário perguntar: a "supremacia do interesse público", ainda que reconhecido seu valor metodológico, é óbice à adoção de práticas consensuais?

\subsubsection{Supremacia do interesse público como óbice para adoção de meios} consensuais?

A visão que se adota sobre a supremacia do interesse público traz conseqüências diretas para a questão da possibilidade da Administração Pública adotar práticas consensuais de resolução de conflitos, vez que tais práticas costumeiramente importam alguma abertura da Administração no sentido de negociar aspectos do bem jurídico por ela perseguido. Por isso, é importante que se entenda a dualidade existente entre os posicionamentos no tema da supremacia: de um lado, a posição de que referido princípio representa uma solução apriorística e, de outro, a ideia de que o valor deste interesse apenas pode ser verificado caso a caso, de forma a permitir alternativas de decisão e ponderação de todos os interesses envolvidos. Paralelamente, o princípio representa, no mínimo um reforço publicista. A tentativa de conciliação de tais posições nos leva ao questionamento sobre a compatibilidade entre a supremacia do interesse público considerada em suas duas visões - e a adoção das práticas consensuais.

Juliana de Palma reconhece a importância da primazia do interesse público como construção legitimadora das prerrogativas da Administração Pública. Contudo, sob este 
viés, o princípio em nada impede a adoção de soluções consensuais para conflitos envolvendo o ente público, pois funciona apenas como legitimador e não como um critério viável de solução $^{147}$.

Destacamos trecho esclarecedor, em que a autora aponta que o interesse público pode muito bem ser atingido por meio da consensualidade:

\footnotetext{
"Ainda que se admita o princípio da supremacia, o ato consensual pode ser considerado o próprio interesse público, de forma que a atuação administrativa consensual não determina a prevalência do interesse privado em detrimento do interesse público, pelo contrário, segundo esse argumento a consensualidade corresponderia ao processo de satisfação do interesse público concretizado no acordo administrativo. O ponto está em considerar não apenas o ato administrativo como expressão do interesse público, mas também o acordo firmado entre Administração e administrado no âmbito do processo, no qual haja negociação da prerrogativa pública (imperativa). Tendo em vista os possíveis efeitos positivos da consensualidade - como a efetividade da decisão bilateral, a economia de tempo e de custos, bem como a maior adequação da solução negociada em relação às particularidades da situação concreta -, é importante que se reconheça o ato consensual como a própria expressão do interesse público" ${ }^{148}$.
}

O que se extrai do trecho é que o interesse público pode ser atendido por meio de meios consensuais, pois: (i) pelo viés material, o interesse público pode ser o próprio resultado da solução consensual; (ii) pelo viés processual, pode ser procedimento pelo qual outras manifestações do interesse público (como legitimidade estatal ou economia de recursos) podem ser atingidas.

Assim, a supremacia do interesse público não pode ser vista como um óbice à adoção de meios consensuais de solução de conflitos pela Administração Pública, seja porque é construção teórica que vem sendo fortemente questionada, seja por, mesmo dentro de sua função epistemológica aceita, não guardar vínculo com critério algum de escolha de meio de solução de conflito.

A adoção de uma solução consensual não significa privilegiar o particular em detrimento do público. O interesse público (aquele obtido após a ponderação dos diversos interesses existentes) pode ser veiculado também pelo ato consensual. Basta notar os Termos de Compromisso firmados no âmbito das Ações Civis Públicas, as quais, em tese, mesmo sendo frutos de consenso, procuram veicular a própria proteção do interesse público.

Além disso, as vantagens que podem decorrer de um método consensual, como a economia de tempo e recursos, o grau de legitimidade proporcionado pela participação do

\footnotetext{
${ }^{147}$ PALMA, Juliana Bonacorsi de. Atuação administrativa consensual, p. 151.
}

${ }^{148}$ PALMA, Juliana Bonacorsi de. Atuação administrativa consensual, p. 153. 
particular na construção da solução, podem atender a um outro aspecto do interesse público. São exemplos disso os programas de arrecadação de tributos em relação a contribuintes inadimplentes, que, segundo relatos levantados na pesquisa empírica, se usado com ponderação, permitem uma arrecadação maior em um tempo mais curto e com menores custos em comparação com o uso da execução físcal.

Se tomarmos ainda a dicotomia "via consensual vs. via adjudicatória", com a qual se trabalha na presente dissertação, não há garantia de que, ao menos em abstrato, a solução adjudicada vá apresentar uma maior proximidade ao interesse público e uma ponderação mais adequada nos casos concretos. Ou seja: a manutenção da via adjudicatória, nos casos em que a via consensual é possível, não é garantidamente um instrumento em defesa da supremacia do interesse público.

É certo que há casos em que a solução adjudicada claramente se mostra mais adequada ao reconhecimento e tutela do interesse público - questão da qual trataremos em item apropriado -, o que decorre de inúmeras variáveis como a diferença de poder entre as partes e a necessidade de impulso judicial a uma discussão (litígio estratégico). Contudo, deve-se concluir que a supremacia do interesse público, além de ser expressão de difícil concreção e de valor metodológico hoje em dia questionável para construção de soluções a casos concretos, não se relaciona diretamente com a escolha do meio de solução dos conflitos envolvendo a Administração Pública.

\subsection{Introdução do princípio da eficiência como guia da atuação administrativa}

O princípio da eficiência administrativa foi introduzido no art. 37 da Constituição Federal pela Emenda Constitucional n. 19/98. É naturalmente um conceito aberto, de desdobramentos que não foram dados pelo texto constitucional. Uma maior concreção do princípio é necessária para que se atribuam sentidos que orientem condutas do Administrador Público.

Percorrendo a literatura administrativita, encontramos explicações que se assemelham. Para Odete Medauar, a eficiência "determina que a Administração deve agir, de modo rápido e preciso, para produzir resultados que satisfaçam as necessidades da população" ${ }^{149}$. Já para Marçal Justen Filho, a eficiência se relaciona a um dever gerencial

${ }^{149}$ MEDAUAR, Odete. Direito Administrativo Moderno. São Paulo: RT, 2012, p. 141-142. 
do agente público, que deve produzir os melhores resultados econômicos, do ponto de vista quantitativo e qualitativo. São concepções do princípio que se aproximam de uma ideia de melhoria da atividade da Administração Pública. Contudo, é difícil que, a partir dessas definições, se extraiam orientações que vão além do plano retórico.

Humberto Ávila, por sua vez, fala não em um princípio, mas em um dever de eficiência da Administração Pública, que "estrutura o modo como deve atingir os seus fins e qual deve ser a intensidade da relação entre as medidas que ela adota e os fins que ela persegue" ${ }^{\prime 150}$. Para o autor, tendo em vista que a eficiência é sim um dever da Administração, resta descortinar qual o conteúdo desse dever. Inicialmente, trata-se de um dever que impõe a correlação entre meios e o fim que se quer atingir. No entanto, o autor busca responder a duas questões sobre essa relação: (1) existe uma obrigação de obter o melhor resultado possível (resultado ótimo) com os meios utilizados? e (2) o critério de escolha do meio a ser utilizado deve levar em conta primordialmente a economia financeira?

Em relação à segunda pergunta, o autor pondera que a questão financeira é apenas uma dentre as muitas que devem ser levadas em conta na tomada da decisão administrativa. Determinada medida pode ser mais barata, gerando menos custos aos administrados, mas, por outro lado, restringido mais intensamente sua liberdade. Nesse caso, não é possível assumir a priori que o menor custo é o critério de escolha da medida. Por outro lado, se o nível de restrição da liberdade for o mesmo, o critério do custo financeiro pode ser adotado. Para o autor "existe o dever de escolher o meio menos dispendioso somente no caso de ficarem inalteradas (ceteres paribus) a restrição dos direitos dos administrados e o grau de realização dos fins administrativos"151.

Quanto à primeira pergunta, o autor se vale do postulado da proporcionalidade para responder: a Administração deve escolher, entre os meios disponíveis para determinado fim, em primeiro lugar, uma medida adequada à consecução da finalidade. Para o autor, isso não significa que a Administração deva escolher o melhor meio em termos qualitativos, o mais abrangente em termos quantitativos ou o mais seguro em termos

150 ÁVILA, Humberto. Moralidade, razoabilidade e eficiência na atividade administrativa. Revista Eletrônica de Direito do Estado. Salvador, IBDP, n. 4, out./dez. 2005, p. 19. Disponível em: < http://www.direitodoestado.com.br/artigo/humberto-avila/moralidade-razoabilidade-e-eficiencia-naatividade-administrativa>. Acesso em: 07/08/2014.

151 ÁVILA, Humberto. Moralidade, razoabilidade e eficiência na atividade administrativa. Revista Eletrônica de Direito do Estado. Salvador, IBDP, n. 4, out./dez. 2005, p. 20-21. Disponível em: < http://www.direitodoestado.com.br/artigo/humberto-avila/moralidade-razoabilidade-e-eficiencia-naatividade-administrativa>. Acesso em: 07/08/2014. 
probabilísticos, mas simplesmente que ele deve empregar um meio que, de alguma forma, chegue à finalidade desejada. Contudo, não pode, ao mesmo tempo, descurar de atingir a finalidade em termos qualitativos, quantitativos e probabilísticos minimamente satisfatórios. Vejamos sua síntese:

Eficiente é a atuação administrativa que promove de forma satisfatória os fins em termos quantitativos, qualitativos e probabilísticos. Para que a administração esteja de acordo com o dever de eficiência, não basta escolher meios adequados para promover seus fins. A eficiência exige mais do que mera adequação. Ela exige satisfatoriedade na promoção dos fins atribuídos à administração. Escolher um meio adequado para promover um fim, mas que promove o fim de modo insignificante, com muitos efeitos negativos paralelos ou com pouca certeza, é violar o dever de eficiência administrativa. $\mathrm{O}$ dever de eficiência traduz-se, pois, na exigência de promoção satisfatória dos fins atribuídos à administração pública, considerando promoção satisfatória, para esse propósito, a promoção minimamente intensa e certa do fim ${ }^{152}$.

Para Juliana Bonacorsi de Palma, essa concepção do princípio da eficiência enquanto imposição de dever de escolha do meio adequado deixa claro o caráter instrumental do Direito Administrativo e de seus instrumentos jurídicos, que se prestam a atingir objetivos públicos específicos (proteção de determinado bioma, controle da qualidade ambiental, promoção da mobilidade urbana de uma região, etc.), mais do que perseguir um interesse público abstrato e etéreo ${ }^{153}$.

Parece, de fato, ser uma concepção mais concreta e operável considerar a eficiência como um dever de adotar medidas adequadas, que satisfaçam qualitativa, quantitativa e probabilisticamente determinado fim, atentando para os custos administrativos envolvidos, que devem ser minimizados salvo se sua redução provocar queda na adequação ou maior restrição de direitos do administrado.

\subsubsection{Eficiência na escolha do meio de atuação e de resolução de conflitos}

O dever de eficiência da administração é normalmente levantado para fundamentar a adoção de meios de solução de conflito alternativos ao Judiciário, tanto adjudicatórios quanto consensuais ${ }^{154}$.

152 ÁVILA, Humberto. Moralidade, razoabilidade e eficiência na atividade administrativa. Revista Eletrônica de Direito do Estado. Salvador, IBDP, n. 4, out./dez. 2005, p. 23-24. Disponível em: < http://www.direitodoestado.com.br/artigo/humberto-avila/moralidade-razoabilidade-e-eficiencia-naatividade-administrativa>. Acesso em: 07/08/2014.

${ }^{153}$ PALMA, Juliana Bonacorsi de. Atuação administrativa consensual, p. 94.

${ }^{154}$ Cf. LEMES, Selma. Arbitragem na Administração Pública. São Paulo: Quartier Latin, 2007, p. 99. 
Luciane Moessa de Souza aponta o princípio da eficiência como fundamento para a adoção de meios consensuais, entendendo-o, no caso, como princípio que orienta que os conflitos sejam resolvidos da forma que melhor apresente a relação custo-benefício, o que se mede segundo o menor custo, no menor tempo, menor desgaste para a relação das partes e melhores resultados para ambas. A autora chega a afirmar, inclusive, que é dever do Poder Público disponibilizar tais métodos de solução de conflitos, não sendo, contudo, os particulares obrigados a neles tomar parte, podendo optar pela via judicial se assim entenderem mais apropriado ${ }^{155}$.

A adoção de um meio consensual pode se revelar unitariamente mais barata do que o uso da via judicial, que demanda, a princípio, maior gasto de tempo e de recursos advindos do próprio Estado -, além da promoção de soluções extremadas que encontram dificuldades para serem realizadas na prática, normalmente pela via executiva, enquanto a solução consensual tem mais chances de ser efetivada voluntariamente.

No entanto, é necessário evitar o entendimento errôneo de que a eficiência deve ser levada ao cabo com sacrifício da legalidade ${ }^{156}$. Como dito, o princípio da legalidade dos atos da Administração Pública tem como objetivo fazer valer a finalidade pública, veiculado pela vontade estatal como representativa da sociedade. Sendo assim, a busca pela eficiência deve ser canalizada conforme as permissões legais dadas à atuação no caso, não podendo a Administração valer-se de expedientes que, apesar de atingir a finalidade de maneira eficiente, desconsideram as margens de sua atuação e violam a própria segurança do ato.

Por outro lado, dentro da definição de eficiência adotada, se o meio consensual mostrar-se apto a solucionar o conflito e, ao mesmo, atingir as finalidades públicas envolvidas, em um tempo e custo menor, e respeito os parâmetros de legalidade, sua adoção certamente é uma forma de otimizar o mandamento de eficiência.

\subsection{Introdução do consenso como forma de atuação administrativa}

${ }^{155}$ SOUZA, Luciane Moessa de. Resolução consensual de conflitos envolvendo o Poder Público: caminho possível e adequado, com o devido respeito às peculiaridades do regime jurídico-administrativo. Revista do Advogado. São Paulo, AASP, n. 123, ago.2014, p. 162-169, p. 163.

${ }^{156}$ Cf. MEDAUAR, Odete. Direito Administrativo Brasileiro. São Paulo: RT, 2012, p. 141-142. 
Juliana Bonacorsi de Palma relata que o Direito Administrativo brasileiro tem passado por mudanças sobretudo em sua metodologia: passa-se à admissão de uma postura instrumental do Direito Administrativo, em que importa cada vez mais a funcionalidade das normas e dos institutos à pesquisa e à gestão pública ${ }^{157}$.

Nessa nova postura metodológica, emergiu o tema da "consensualidade" entre os administrativistas brasileiros. Segundo a autora, os fatores que levaram à inserção do debate em torno do tema no Brasil, inspirado pelo debate outrora travado na Europa Continental, são a democracia substantiva, a contratualização da atuação da administração, e a eficiência como diretriz dessa atuação ${ }^{158}$.

Segundo Justino de Oliveira, a inserção da consensualidade na pauta de discussão dos administrativistas se fundamenta na modificação da visão da função do Estado ${ }^{159}$.

O autor explica que as bases do Direito Administrativo Brasileiro são encontradas na concepção liberal de Estado do século XIX, e foi a partir daí que institutos e conceitos vigentes até hoje foram moldados. Forjou-se a ação administrativa típica por meio de atos administrativos, carregados de imperatividade, e construídos a partir da dualidade autoridade-liberdade, visto como opostos. Segundo o autor, esse é o momento da administração autoritária, marcada pela desigualdade entre administração e indivíduos e pela atribuição de autoridade aos agentes administrativos. Era um modelo que tinha como objetivo assegurar o poder político por meio de instrumentos jurídicos, mas que não contemplava os interesses dos indivíduos ${ }^{160}$.

A função do Estado, contudo, altera-se de impositiva para garante dos direitos fundamentais e mediadora. O Estado mediador deve não apenas estabelecer canais de participação com indivíduos e grupos sociais, mas também de compor interesses públicos e privados em jogo, incluindo os cidadãos no processo de definição do conceito de interesse público. É um modelo que se sobrepõe ao modelo de Estado como mero titular do poder de império $^{161}$.

\footnotetext{
${ }^{157}$ PALMA, Juliana Bonacorsi de. Atuação administrativa consensual: Estudo dos acordos substitutivos no processo administrativo sancionador, Dissertação (mestrado) - Faculdade de Direito da Universidade de São Paulo (USP), São Paulo, 2009, p. 11.

${ }^{158}$ PALMA, Juliana Bonacorsi de. Atuação administrativa consensual, p. 82-83.

${ }^{159}$ OLIVEIRA, Gustavo Justino de. A Administração consensual como a nova face da Administração pública no século XXI: fundamentos dogmáticos, formas de expressão e instrumentos de ação. In: OLIVEIRA, Gustavo Justino de. Direito administrativo democrático. Belo Horizonte: Fórum, 2010, p. 211-231, p. 218.

${ }^{160}$ OLIVEIRA, Gustavo Justino de. A Administração consensual como a nova face da Administração pública no século XXI, p. 218.

${ }^{161}$ OLIVEIRA, Gustavo Justino de. A Administração consensual como a nova face da Administração pública no século XXI, p. 218-219.
} 
Nesse novo modelo de Estado, a suficiência da atuação por meio do ato administrativo é posta em xeque. Juliana Bonacorsi de Palma relata o ceticismo que existe atualmente no Direito Administrativo em relação à capacidade do modelo clássico responder aos deveres do Estado, sobretudo levando em conta a necessidade de eficiência da atuação administrativa ${ }^{162}$.

Assim, a consensualidade emerge como novo paradigma do Direito Administrativo, com a promessa de atender às demandas do Estado garante de direitos fundamentais, sobretudo em cenários de pluralidade de interesses. A ideia é não somente arbitrar interesses, mas também compô-los, sejam entre dois ou mais particulares, sejam entre particulares e o Poder Público ${ }^{163}$.

Segundo a autora, o debate travado no Brasil sobre consensualidade tem dito mais respeito ao seu conteúdo do que às formas de operação de seus instrumentos. Ainda há divergência, epistemologicamente, sobre o que seria a consensualidade para fins de seu estudo.

Há divergência sobre os tipos de instrumentos e sobre sua listagem. Juliana Palma identifica algumas correntes: (i) a mais ampla, toma a consensualidade como qualquer forma de ingerência privada na Administração Pública, ou seja, que viabilize o diálogo entre Administração Pública, ainda que a decisão final seja um ato imperativo e unilateral, incluindo-se aí as audiências e consultas públicas; (ii) em sentido menos amplo a consensualidade envolveria qualquer acordo de vontades entre a Administração Pública e o particular, incluindo contratos, acordos com particulares, acordos intergovernamentais e transações; (iii) essa concepção mais ampla pode se restringir a atos que ocorram exclusivamente no âmbito administrativo, de forma que ficariam excluídos acordos judiciais; (iv) há uma concepção ainda mais restrita, segundo a qual a consensualidade abrangeria apenas a "concertação administrativa", que é a "negociação da prerrogativa imperativa que a Administração Pública detém para impor unilateralmente suas decisões administrativas"

Interessa-nos, sobretudo, a concepção ampla (ii), em que fica claro o fenômeno da “contratualização", em que, conforme será melhor explicado, se inserem os instrumentos de interesse de estudo: a conciliação e a transação administrativas.

\footnotetext{
${ }^{162}$ PALMA, Juliana Bonacorsi de. Atuação administrativa consensual, p. 11.

${ }^{163}$ PALMA, Juliana Bonacorsi de. Atuação administrativa consensual, p. 132.

164 PALMA, Juliana Bonacorsi de. A consensualidade na Administração Pública e seu controle judicial. GABBAY, Daniela Monteiro; TAKAHASHI, Bruno (coor.). Justiça Federal: inovações nos mecanismos consensuais de solução de conflitos. Brasília: Gazeta Jurídica, 2014, p. 143-188, p. 148-153
} 
Segundo Justino de Oliveira, a contratulização "retrata a substituição das relações administrativas baseadas na unilateralidade, na imposição e na subordinação por relações fundadas no diálogo, na negociação e na troca"165. Tais atos se revelam instrumentos importantes no consensualismo da administração, que demonstram uma forma mais ampla de contratualização, não limitada ao contrato administrativo clássico.

A contratualização do Direito Administrativo é fenômeno que amplia as relações bilaterais entre Estado e particulares para além do contrato administrativo clássico. Neste, há claro desnível entre as partes, revelado inclusive nas prerrogativas da administração pública, como a de rescisão unilateral.

Segundo Juliana de Palma, a contratualização da Administração Pública se revela no aumento das previsões de figuras contratuais para exercício das funções públicas, bem como pela maior adoção desses meios pelo Estado. No Brasil, merecem destaque as parcerias público-privadas, que cresceram em importância na gestão pública nos últimos $\operatorname{anos}^{166}$.

$\mathrm{Na}$ tipologia traçada por Gustavo Justino de Oliveira, o fenômeno da contratualização abrange o acordo administrativo, que seria é gênero do qual o "contrato" é espécie, assim como a conciliação e a transação administrativa, objetos de interesse deste trabalho. Vale transcrever os conceitos delimitados pelo autor:

\begin{abstract}
A transação administrativa representa uma estratégia de negociação por meio da qual as partes envolvidas na relação jurídico-administrativa controvertida, mediante concessões recíprocas, previnem ou terminam o litígio. Assim, para ocorrer a transação é essencial a existência de uma relação jurídica controvertida, na qual a solução é estabelecida pelas próprias partes, devendo resultar, não da vontade unilateral, mas da vontade das partes litigantes de estabelecerem, de comum acordo, a solução para o conflito.

Por outro lado, se a solução do conflito é conferida por terceiro alheio ao litígio, o qual procura aproximar as partes e promover a busca do entendimento entre elas, estar-se-á diante da conciliação, e não da transação ${ }^{167}$.
\end{abstract}

Como visto, para o autor, a transação é o acordo a que se chega sobre uma relação jurídica controvertida entre as partes, mediante concessões recíprocas. Se o processo de construção da solução é facilitado por um terceiro, então ocorrerá uma conciliação.

A tipologia traçada pelo autor comporta algumas observações.

\footnotetext{
165 OLIVEIRA, Gustavo Justino de. A Administração consensual como a nova face da Administração pública no século XXI, cit., p. 224.

${ }^{166}$ PALMA, Juliana Bonacorsi de. Atuação administrativa consensual, cit., p. 85.

${ }^{167}$ OLIVEIRA, Gustavo Justino de. A Administração consensual como a nova face da Administração pública no século XXI, p. 227.
} 
O conceito de "transação administrativa" dado pelo autor é inspirado na redação do art. 840 do Código Civil, segundo o qual "[é] lícito aos interessados prevenirem ou terminarem o litígio mediante concessões mútuas”. O conceito de transação leva à ideia de disponibilidade do interesse, através de "concessões mútuas”, ou seja, os envolvidos abrem mão de parte de seu direito. Como já narrado, um dos entraves à adoção dos meios consensuais de solução de conflitos pela Administração Pública é justamente a visão limitada sobre o conceito de "indisponibilidade do interesse público".

Será melhor tratado em tópico próprio que o conceito de transação não abrange toda a potencialidade de bons resultados dos meios consensuais de solução de conflitos. Sendo possível compô-los sem realizar concessões, não seria adequado adotar a transação como subtipo do "acordo administrativo". Para designar acordos sobre relações jurídicas controvertidas, seria mais adequado falar simplesmente em "acordo em sentido estrito", do qual a transação é uma subespécie, caso o acordo resulte em concessões recíprocas.

A “conciliação" apontada pelo autor, enquanto instrumento em que o acordo é obtido mediante a intervenção de um terceiro imparcial, deve ser entendido em sentido amplo, a fim de abranger também a "mediação", que é instrumento que, conforme veremos em tópico próprio, possui algumas particularidades.

Assim, é necessário delimitar o conceito de consensualidade aqui adotado. A presente dissertação não trata especificamente da substituição da prerrogativa sancionadora pelo ato consensual, tampouco de instrumentos de participação popular na Administração. Trata, sim, da substituição da heterocomposição de conflitos pelo Poder Judiciário por uma composição consensual, que resulta em nada mais que um acordo de vontades, refletindo o fenômeno da contratualização.

Por isso, é adequado assumir um conceito mais amplo de consensualidade, que permita abarcar qualquer acordo de vontades entre a Administração Pública e o particular. 


\section{Parte II - Meios consensuais e Administração Pública}

\section{ESCLARECIMENTOS CONCEITUAIS}

Antes de tratar das particularidades do uso dos meios consensuais pela Administração Pública, serão esclarecidos alguns conceitos importantes para prosseguir na discussão com maior precisão.

\subsection{Conflito}

Ao se tratar do termo "conflito" com a intenção didática de delimitar o objeto sobre o qual operam os meios consensuais de solução, imediatamente vem à mente dos mais acostumados à linguagem jurídica a identificação com a "lide" nadefinição clássica de Carnelutti ${ }^{168}$, que designa um "conflito de interesses qualificado por uma pretensão resistida".

No âmbito do processo civil, Cândido Rangel Dinamarco critica a noção de lide, apontando ser "exageradamente ligada a relações de direito privado" e desconsiderar que "na vida social o que incomoda e aflige não é a teórica incidência de interesses sobre o

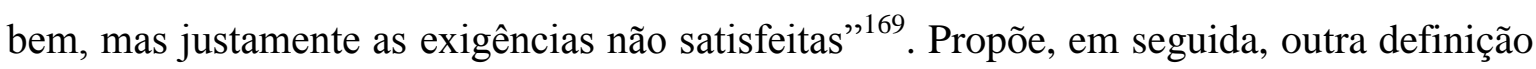
de conflito, atendo-se ainda àquele de interesse ao processo civil: "É a situação existente entre duas ou mais pessoas ou grupos, caracterizados pela pretensão a um bem ou situação da vida e impossibilitado de obtê-lo - seja porque negada por quem deveria dá-lo, seja porque a lei impõe que só possa ser obtido por via judicial" ${ }^{\text {"170 }}$. No entanto, a definição do autor ainda é ligada à qualificação jurídica dos fatos (ao fazer referência à pretensão e à violação de um dever) e à forma judicial de resolução.

Fernanda Tartuce, por outro lado, adverte que o conflito extrapola a noção de lide, muito vinculada ao conflito em seu recorte feito em juízo. Para a autora, as relações

168 Cf. DINAMARCO, Cândido Rangel. Instituições de direito processual civil. 6. ed. São Paulo: Malheiros, 2009, v. 1, p. 120.

${ }^{169}$ DINAMARCO, Cândido Rangel. Instituições de direito processual civil, cit., p. 120.

${ }^{170}$ DINAMARCO, Cândido Rangel. Instituições de direito processual civil, cit., p. 121. 
interpessoais são marcadas pela insatisfação, e é esta a nota dada ao conflito $^{171}$, independentemente de qualificação jurídica dessa insatisfação.

De fato, quando tratamos de meios consensuais, o conflito é levado em consideração em termos mais amplos do que o jurídico-processual, que está limitado à matéria levada em juízo pelas partes, que pode representar apenas uma parte de um conflito maior e que deve, na maior parte dos casos, ser decidida a partir de um recorte jurídico, ou seja, de aplicação do direito positivo. A via consensual, por sua vez, capta o conflito de forma diferente, sem as mesmas molduras e separações entre aspecto processual e substancial $^{172}$.

O conflito, tomado em sentido mais amplo que o jurídico-processual, pode se manifestar em diferentes formas jurídicas: é comum que um único conflito se desdobre (ou possa se desdobrar) em inúmeras demandas judiciais ou "crises de direito": tome-se como exemplo a separação de um casal, que gera uma demanda de divórcio, outra de alimentos para os filhos menores e outra de guarda, reservado ainda o espaço para futuras demandas modificativas (exoneração de alimentos, revisional de visitas, modificação de guarda, etc.), seja por alteração da situação fática ou seja porque o conflito não foi adequadamente tratado da primeira vez ${ }^{173}$.

Em sentido leigo, o conflito abrange outros significados, como oposição de interesses, de sentimentos, ideias. Ademais, envolve aspectos não apenas jurídicos, mas também econômicos, psicológicos, sociológicos, filosóficos. Por tal motivo, o tema do conflito vem sendo estudado por prismas multidisciplinares, inclusive os conflitos que envolvam transgressões jurídicas ${ }^{174}$. A lide, ou disputa processual, não corresponde necessariamente ao conflito, pois há filtragem dos elementos, ainda que o processo tenha sido concebido com a pretensão de um continente de conflitos ${ }^{175}$.

Meios consensuais de solução de conflitos podem ter como objeto o conflito em sentidos mais amplos que o recorte processual (dado pela adstrição ao pedido) e mesmo mais amplos que o sentido jurídico, levando em conta intenções atribuídas e expectativas

\footnotetext{
${ }^{171}$ TARTUCE, Fernanda. Mediação nos conflitos civis. São Paulo: Método, 2007, p. 24-25.

172 Cf. GABBAY, Daniela Monteiro. Mediação e Judiciário: Condições necessárias para a institucionalização dos meios autocompositivos de solução de conflitos. Tese (Doutorado) - Faculdade de Direito da Universidade de São Paulo. São Paulo, 2011, p. 30-31.

${ }^{173}$ FREITAS JR., Antonio Rodrigues. Sobre a relevância de uma noção precisa de conflito. Revista do Advogado. São Paulo, AASP, n. 123, p. 11-23, ago./2014, p. 12.

${ }^{174}$ Cf. TARTUCE, Fernanda. Mediação nos conflitos civis, cit., p. 25-28.

${ }^{175}$ FREITAS JR., Antonio Rodrigues. Sobre a relevância de uma noção precisa de conflito, cit., p. 12.
} 
não atendidas que nem sempre interessam ao direito. É o caso, por exemplo, da mediação familiar $7^{176}$.

No âmbito do conhecimento jurídico, os meios consensuais de solução de conflitos contribuem para trazer o ponto de observação sobre o conflito para fora dos limites do Judiciário e da linguagem processual ${ }^{177}$.

Tendo o conflito várias dimensões (jurídica, psicológica, social, etc.), os meios que atuarão sobre ele levam em consideração diferentes elementos; fazendo, assim, diferentes recortes. Como já vimos, o processo judicial dá seu próprio recorte ao conflito, limitado à crise jurídica e à matéria trazida ao Juízo.

Vale ainda mencionar a existência de abordagem específica da mediação conhecida como "mediação transformativa", bastante difundida na literatura norte-americana, advogada especialmente pelos autores Joseph P. Folger e Robert A. Baruch Bush. Segundo esse enfoque, a mediação é mais que um meio de se "resolver" conflitos, sendo o seu objetivo, na verdade, tomar o conflito como uma oportunidade para (i) exercício da autodeterminação e do autorreconhecimento das pessoas, revalorizando o indivíduo, e (ii) exercício do reconhecimento do outro de modo a oportunizar o exercício do respeito e consideração mútuos. Essa vertente da mediação se importa mais com a dimensão moral do conflito, e tem como objetivo a transformação do indivíduo mais do que a sua satisfação em relação ao seu aparente objeto de disputa, que aqui aparece apenas como a ponta de um iceberg que guarda submersos aspectos mais profundos ${ }^{178}$.

Essa vertente da mediação enfatiza o aspecto subjetivo e psicológico do conflito, com foco nas questões interpessoais, deslocando o eixo do problema objetivo para as nuances subjetivas do conflito.

Os teóricos dessa corrente desenvolveram-na e estimularam-na com o objetivo de superar a limitação que viam na corrente predominante da mediação, a corrente da mediação satisfativa. Segundo esta outra vertente, o processo de mediação é ferramenta eficiente para a satisfação das necessidades humanas. Assim, por não se entender atada às soluções legais prévias, a mediação permitiria que as partes envolvidas revelassem todos

\footnotetext{
${ }^{176}$ SAMPAIO, Lia Regina Castaldi; BRAGA NETO, Adolfo. O que é mediação de conflitos. São Paulo: Brasiliense, 2007, p. 96.

${ }^{177}$ FREITAS JR., Antonio Rodrigues. Sobre a relevância de uma noção precisa de conflito. cit., p. 12.

${ }^{178}$ Cf. BUSH, Baruch Robert A.; FOLGER, J. P. La promesa de mediación: Como Afrontar el Conflicto a Través del Fortalecimiento Propio y el Reconocimiento de los Otros. Buenos Aires: Granica, 1996, p. 46-49, 129-134.
} 
os aspectos do conflito para, tomando-o como problema comum, desenvolver colaborativamente soluções criativas que satisfaçam às necessidades de $\operatorname{todos}^{179}$.

Essa corrente tem como obra mais popular o famoso livro-manual de negociação "Getting to Yes", desenvolvido no âmbito do Negotiation Project da Escola de Direito da Universidade de Harvard, que traz um guia para soluções eficientes e eficazes de problemas segundo uma pauta de princípios de negociação: (a) separar as pessoas dos problemas; (b) focar em interesses e não posições; (c) inventar opções para ganhos mútuos; e (d) utilização de critérios objetivos ${ }^{180}$. Em comparação com a mediação transformativa, essa abordagem faz um recorte do conflito que considera mais intensamente a oposição (aparente ou real) e a convergência de interesses.

Os adeptos da mediação transformativa sustentam que a abordagem satisfativa limita o potencial da solução consensual de conflitos, ao priorizar apenas um de seus aspectos e relegar a segundo plano aspectos psicológicos e morais.

Essa digressão às escolas de mediação nos demonstra que, quando tratamos de solução consensual de conflitos, não há uma definição única e preponderante do que é o conflito. Assim, mais do que um esforço ontológico, é necessário buscar uma definição que seja útil para uma abordagem teórica específica.

Desse modo, nãoexiste um fenômeno único que possa ser denominado "conflito", pois este comporta muitas dimensões e designa situações diferentes: disputas de poder, conflitos intrapsíquicos, disputas esportivas. O que importa, então, para o estudo da solução de "conflitos" envolvendo a Administração Pública? Antonio Rodrigues de Freitas Jr. nos adverte que o fato de "conflito" ser fenômeno polissêmico não autoriza que em cada setor do conhecimento se empregue a palavra de modo impreciso e sem uma acepção delimitada; sua delimitação teórica é necessária para objetivos eminentemente práticos, ou seja, para saber em que exatamente a solução de conflitos atuará ${ }^{181}$. Já temos que o conflito não é limitado às lides processuais.

No caso da presente dissertação, devemos ter em mente as peculiaridades do ente público, que é necessariamente um dos sujeitos dos conflitos cujos meios para solução serão aqui estudados. Assim, é importante considerar alguns elementos: (i) a Administração Pública lida com recursos escassos, advindo de receitas públicas; (ii) a

\footnotetext{
${ }^{179}$ Conforme explicação sintética contida em: BUSH, Baruch Robert A.; FOLGER, J. P. La promesa de mediación, cit., p. 40-43.

${ }^{180}$ Cf. FISHER, Roger; URY, William; PATTON, Bruce. Getting to Yes: Negotiation agreement without giving in. 3. ed. New York: Penguin Books, 2011.

${ }^{181}$ FREITAS JR., Antonio Rodrigues. Sobre a relevância de uma noção precisa de conflito, cit., p. 13-14.
} 
finalidade da atividade administrativa, como se concluiu a partir do capítulo anterior, é nada mais que a promoção de interesses públicos que lhe foi atribuída; (iii) os instrumentos da atividade administrativa e, nesse caso, especificamente os de solução de conflitos, são meios para a promoção desses interesses; (iv) a atuação administrativa é pautada pela impessoalidade, o que significa não diferenciar sujeitos por critérios que não sejam objetivos; (v) tratamos, especificamente, da dicotomia entre solução consensual e solução adjudicada, inseridas na discussão sobre acesso à justiça.

O conceito apresentado por Antônio Rodrigues Freitas Jr. parece atender bem aos propósitos do trabalho. Os conflitos que interessam, especificamente, ao direito, às políticas públicas e às políticas de justiça, segundo o autor, são os “conflitos intersubjetivos de justiça”, que implicam em: “1) dois ou mais sujeitos; 2) duas ou mais possibilidades de decisão alocativa - ou seja, um problema alocativo; 3) dois ou mais comportamentos orientados em sentido contraposto", nos quais 4) se contrastam "necessariamente duas ou mais apropriações morais sobre a mais justa hipótese de decisão alocativa" ${ }^{\prime 182}$.

Em outra obra, o autor sintetiza o conceito do seguinte modo:

são as situações em que estejam presentes, simultaneamente, i. no plano objetivo: um problema alocativo incidente sobre bens tidos por escassos ou encargos tidos como necessários, sejam os bens e os encargos de natureza material ou imaterial; ii. no plano comportamental: consciente ou inconsciente, intencional ou não, contraposição no vetor de conduta entre dois sujeitos e; iii. No plano anímico ou motivacional: sujeitos portadores de percepções diferentes sobre como tratar o problema alocativo, como função de valores de justiça ${ }^{183}$.

Esmiuçando o conceito, o autor explica que nos conflitos de justiça os sujeitos (dois ou mais) se encontram diante de um problema alocativo, ou seja, um problema do qual "emerge o ônus de decidir a quem e o quanto destinar: um bem, material ou imaterial, que se supõe escasso, ou um encargo, material ou imaterial, que se reputa inevitável" ${ }^{184}$.

Em relação ao bem escasso, temos como exemplo típico a destinação de alimentos em um cenário de escassez: é preciso escolher aqueles a quem serão destinados e aqueles a quem não serão destinados os alimentos. A escassez, ainda, é deliberada ou

\footnotetext{
${ }^{182}$ FREITAS JR., Antonio Rodrigues. Sobre a relevância de uma noção precisa de conflito, cit., p. 15.

${ }^{183}$ FREITAS JR., Antonio Rodrigues de. Conflitos de Justiça e limites da mediação para a difusão da cultura de paz. SALLES, Carlos Alberto de. As grandes transformações do processo civil brasileiro: homenagem ao Professor Kazuo Watanabe. São Paulo: Quartier Latin, 2009, p. 518.

${ }^{184}$ FREITAS JR., Antonio Rodrigues. Sobre a relevância de uma noção precisa de conflito, cit., p. 15.
} 
conscientemente produzida ${ }^{185}$, por exemplo, quando o Poder Público limita os recursos para destinada área (como saúde ou compra de medicamentos) por meio de uma dotação orçamentária, ou, ainda, quando um pai decide destinar determinada parte de sua renda ao sustento do filho que não está sob sua guarda.

Contudo, apenas emerge a situação conflituosa se desse problema alocativo surgirem também comportamentos antagônicos, vetorialmente contrapostos, conscientes ou não da contraposição, intencionais ou não ${ }^{186}$.

Há, por fim, a divergência moral sobre a solução mais justa para o problema alocativo. $\mathrm{O}$ autor ressalva o aspecto moral porque, para que haja uma situação conflituosa de interesse, pode haver divergência em relação à interpretação jurídica a respeito, mas, mesmo havendo consenso quanto à solução jurídica, pode haver divergência em relação a aspectos que extrapolem o jurídico ${ }^{187}$.

As três primeiras características da definição sobre conflito trazida pelo autor aplicam-se perfeitamente ao interesse dessa dissertação. A quarta delas (divergência moral quanto à justiça da decisão), ainda que caracterize o conflito de interesse de resolução para a Administração Pública, merece uma discussão mais aprofundada quanto aos limites da resolução consensual de conflitos na esfera pública, que será tratada em item próprio. A pergunta é, basicamente, se a Administração Pública pode atentar para divergências morais quanto à justiça de suas decisões ou se deve estar adstrita à interpretação jurídica.

\subsubsection{Solução de conflitos}

Para Fernanda Tartuce, o conflito nem sempre pode ser "resolvido", no sentido de "extinto", por um ato isolado. Segundo a autora, o termo "composição" é mais adequado, pois em vez de designar uma pretensa extinção da controvérsia, a composição "indica reorganização e estruturação do conflito em uma nova disposição". É, no final, uma forma de resposta à situação conflitiva com a participação dos envolvidos ${ }^{188}$, que não necessariamente extingue o conflito em um único ato.

\footnotetext{
${ }^{185}$ FREITAS JR., Antonio Rodrigues. Sobre a relevância de uma noção precisa de conflito, cit., p. 15.

${ }^{186}$ FREITAS JR., Antonio Rodrigues. Sobre a relevância de uma noção precisa de conflito, cit., p. 15.

${ }^{187}$ FREITAS JR., Antonio Rodrigues. Sobre a relevância de uma noção precisa de conflito, cit., p. 15.

${ }^{188}$ TARTUCE, Fernanda. Mediação nos conflitos civis, cit., p. 35-36
} 
Segundo Cândido Rangel Dinamarco, a expressão “compor a lide” já recebeu, de Francesco Carnelutti, o sentido de criar a norma que a resolve. Para o autor, contudo,

\begin{abstract}
a composição que ele realiza (heterocomposição) ou que realizam os próprios litigantes (autocomposição), não consiste em estabelecer normas, mas em produzir resultados práticos socialmente úteis, representados pela concreta atribuição de bens ou definição de condutas permitidas ou vedadas - ou seja, a eliminação do conflito e a pacificação dos litigantes. Também as pessoas em conflito não criam normas para dirimir o conflito em que se encontram: simplesmente dirimem o conflito, põem-lhe fim, sem qualquer preocupação com norma alguma ${ }^{189}$.
\end{abstract}

O conceito de Dinamarco faz sentido no âmbito jurídico-processual. De fato, a composição, com atribuição de bens e definição de condutas, dirime, põe fim ao recorte do conflito submetido ao processo judicial.

Todavia, na definição de conflito que aqui adotamos, mais ampla do que o recorte jurídico-processual, falar em eliminação e pacificação do conflito como elementos definidores da composição é pretensioso. Pode-se falar em termos de objetivo, mas a composição em si não elimina o conflito. É viável, por outro lado, adotar tal definição de composição no sentido de "concreta atribuição de bens ou definição de condutas permitidas ou negadas", que parece adequada aos problemas alocativos que aqui discutimos.

Não obstante o termo "composição" seja mais adequado, "resolução" e "composição" são normalmente usados como sinônimos para designar o resultado prático positivo da atuação de um meio consensual ou adjudicatório.

Cumpre ainda anotar que a "resolução" ou "composição" de conflitos pode se dar em diferentes instâncias, formais ou informais. Roberto Ferrari Ulhôa Cintra concebe a "solução" de conflitos em uma estrutura piramidal composta de diversos degraus. Segundo o autor, as instâncias judiciais ocupariam o ápice da pirâmide em termos de adequação do instrumento, após as partes envolvidas no conflito terem passado por outras formas nãoadversariais e extrajudiciais de solução de conflitos:

${ }^{189}$ DINAMARCO, Cândido Rangel. Instituições de direito processual civil, cit., p. 125. 


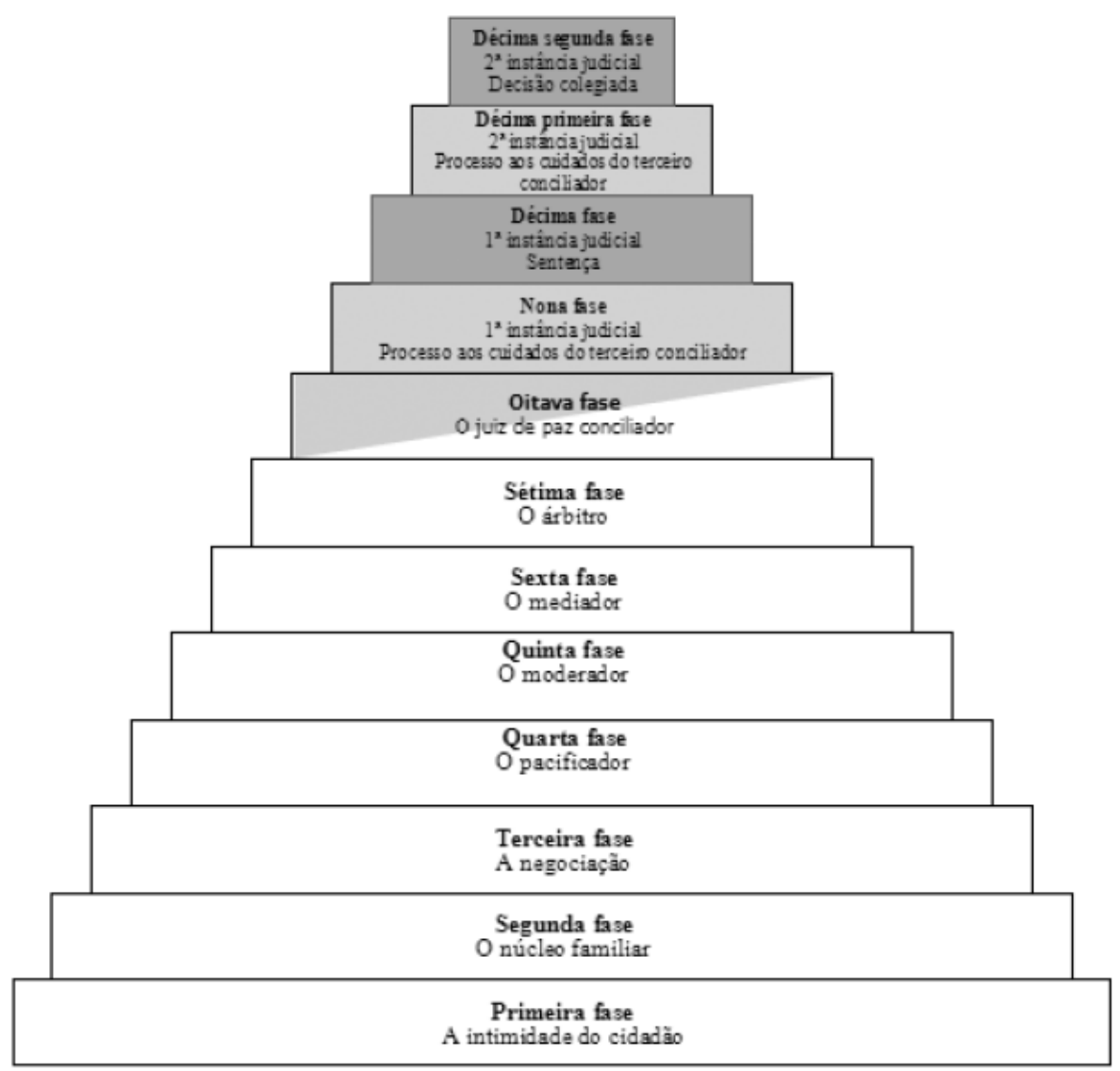

Figura 1: "A pirâmide de solução de conflitos". Fonte: CINTRA, Roberto Ferrari de Ulhôa. A pirâmide de solução de conflitos: uma contribuição de sociedade civil para a reforma do Judiciário. Brasília: Senado Federal, 2008, p. 74.

Dessa forma, antes de se tornarem "autor e réu", os envolvidos em um conflito passariam por outras instâncias amigáveis em que poderiam, inclusive, detectar melhor o conflito. Importante ressalvar, contudo, que o autor não defende a mediação compulsória, mas apenas a disponibilização de meios para que as pessoas possam se valer de outras formas de resolução de conflitos ${ }^{190}$.

É relevante notar que, não obstante o mérito da proposta em ter o processo judicial como instância residual de resolução de conflitos, o aproveitamento dessa estrutura passa, necessariamente, pela análise da adequação dos instrumentos que correspondem aos diversos degraus dos conflitos submetidos e aos objetivos da sua resolução, de forma que não é uma estrutura que pode ser utilizada indistintamente.

É necessário ter em vista, também, que nem todos os conflitos poderão escalar os degraus da pirâmide e desembocar no Judiciário, pois alguns são configurados por

${ }^{190}$ CINTRA, Roberto Ferrari de Ulhôa. A pirâmide de solução de conflitos: uma contribuição de sociedade civil para a reforma do Judiciário. Brasília: Senado Federal, 2008, p. 78. 
elementos não jurídicos, de caráter psicológico ou afetivo e não apreendidos jurídicoprocessualmente.

\subsubsection{Conflito e Administração Pública}

Especificamente no âmbito da Administração Pública e no estudo do Direito Administrativo, existe certa resistência em assumir a Administração Pública envolvida em “conflito" propriamente dito, conforme a acepção acima delineada.

Isso foi verificado na pesquisa empírica realizada nesta dissertação. Segundo o relato de alguns procuradores, a Administração Pública, em meios consensuais, não estaria propriamente compondo conflitos na qual está envolvida, mas sim aplicando a lei ou corrigindo um equívoco de aplicação da lei.

Alguns exemplos de iniciativas no âmbito da Administração acenam em sentido contrário, como a Câmara de Conciliação e Arbitragem da Administração Federal (CCAF), que adota, em sua cartilha, a definição de "controvérsia" como "conflito de interesses entre órgãos ou entidades da Administração Pública Federal, e entre esta e a Administração Pública dos Estados, do Distrito Federal e dos Municípios"191, assumindo que existe conflito até mesmo no âmbito interno da Administração.

Carlos Alberto de Salles explica a dita resistência considerando as próprias bases do Direito Administrativo. Segundo ele, a ideia de que a Administração Pública não se envolve em conflito é calcada na noção de que às relações de Direito Público normalmente se empresta um caráter vertical, ou seja, a Administração está em um patamar mais elevado que o particular, impondo sua autoridade em definir direitos e obrigações dos particulares. Trata-se de um desdobramento da supremacia do interesse público como princípio fundante do Direito Administrativo ${ }^{192}$.

Desse modo, a situação conflitiva não chega a se configurar, pois se há supremacia do interesse da Administração, este sempre prevalecerá em face do direito do administrado e a situação é resolvida, ainda que provisoriamente, pela autotutela, até que o jurisdicionado impugne o ato. Não por outro motivo, não se fala em solução de

${ }^{191}$ CÂMARA DE CONCILIAÇÃO E ARBITRAGEM DA ADMINISTRAÇÃO FEDERAL. Cartilha. 3. ed. Brasília: AGU, 2011, p. 12.

${ }^{192}$ SALLES, Carlos Alberto de. A arbitragem na solução de controvérsias contratuais da administração pública, cit., p. 171. 
controvérsias, mas em controle judicial da Administração, "como se tal função fosse exercida pelo Judiciário independentemente da provocação das partes e não fosse feita apenas no ensejo de uma contraposição de interesses a justificar a atuação judicial" ${ }^{193}$.

Para o autor, contudo, o "controle jurisdicional” da Administração nada mais é que um efeito da apreciação, pelo Judiciário, de ameaças e lesões a Direitos, em relação aos quais pendem um litígio decorrente de uma decisão imperativa. A visão do Judiciário como órgão de controle da Administração e da desconsideração da existência de conflito envolvendo a Administração Pública gera deletérias consequências para o trato das coisas públicas e encaminhamento dos negócios do Estado, retirando da Administração a função de solucionar conflitos de forma eficiente, impedindo a utilização de outros meios de solução de conflitos e tornando o relacionamento com particulares mais difícil e custoso ${ }^{194}$.

Além da concepção tradicional de supremacia do interesse público, a ideia de legalidade absorvida pela cultura administrativa também colabora para a resistência ao reconhecimento do envolvimento da Administração Pública em conflitos.

Os conceitos de legalidade e de interesse público (tais quais normalmente concebidos) propiciam a construção da "unilateralidade do contrato administrativo". Os três, em conjunto, inviabilizam as tentativas consensuais de solução de conflitos. No entanto, a "maneira formalista" de se considerar a legalidade leva a distintos significados: mais do que o dever de a Administração se submeter à lei, passa a significar a "presunção de legalidade" dos próprios atos administrativos, independentemente de seu conteúdo; o quê, segundo o autor, perde de vista que os ordenamentos atuais são conturbados pela perda de coerência interna e pela pluralidade de sentido das normas ${ }^{195}$.

Tal ponto é bastante importante para a compreensão de como os meios consensuais de composição de conflitos podem colaborar para a tomada de decisões administrativas. Há, em primeiro lugar, uma situação mais simples, representada pelas as hipóteses nas quais a Administração Pública pode reconhecer, mediante aprimoramento do diálogo e melhor análise da situação fática e jurídica, que determinado ato administrativo não atendeu à lei, valendo-se assim de sua prerrogativa de revisão.

\footnotetext{
${ }^{193}$ SALLES, Carlos Alberto de. A arbitragem na solução de controvérsias contratuais da administração pública, cit., p. 172-173.

${ }^{194}$ SALLES, Carlos Alberto de. A arbitragem na solução de controvérsias contratuais da administração pública, cit., p. 174-175.

${ }^{195}$ SALLES, Carlos Alberto de. Arbitragem em contratos administrativos, São Paulo: Método, 2011, p. 174-175.
} 
Conforme verificado na pesquisa empírica, tal situação é a mais costumeira (ainda que rara), , em que a Administração Pública transige em juízo em situações nas quais o caso se amolda a súmulas de entendimento administrativas ou a evidente ilegalidade, como na hipótese de cancelamentos de multas de trânsito.

Outros casos são aqueles nos quais não há uma situação normativa clara, e que a Administração Pública se vê obrigada a lidar com conceitos indeterminados (como “interesse público”) e imprecisão normativa. São casos em que é possível a construção de um conteúdo decisório mediante um processo legitimador, que pode ser adjudicatório (como no caso das Ações Civis Públicas) ou consensual (como nos casos dos Termos de Ajuste de Compromisso).

Segundo Salles, a absoluta presunção de legalidade dos atos da administração “[o]mite, assim, o conflito que se estabelece já no plano normativo, mesmo sem dissídio no âmbito fático, dizendo respeito à correta aplicação da norma e à própria escolha da norma aplicável ao caso concreto". Se a legalidade deixa de ser condicionante da ação administrativa para se tornar uma qualidade, tem-se que o conteúdo da legalidade em cada caso concreto é dado unilateralmente pela Administração, excluindo-se "a possibilidade de solução consensual do conflito normativo e, por via indireta, também aquele relativo a controvérsia de fato, pois essas últimas, igualmente, acabam equacionadas pelos critérios de legalidade estabelecidos pela autoridade pública"196.

Destacando essa percepção, Justino de Oliveira também acentua que a Administração deve reconhecer e tratar adequadamente seus conflitos para além da solução adjudicatória:

Além disso, há uma ideia generalizada de que os conflitos em que a Administração ocupa um dos pólos devem ser resolvidos exclusivamente pelo Judiciário, o que, além de infundado, constitui um desrespeito monumental aos direitos e garantias do cidadão dispostos na Constituição de 1988.

A Administração não está acima do conflito: ela é obrigada a envidar todos os esforços e recursos disponíveis para a sua solução, para superá-lo na própria esfera administrativa, e não deslocar a legitimidade da tarefa para o Poder Judiciário. Posturas administrativas com esse delineamento estão fadadas a provocar a responsabilização de seus autores, pois configuram má administração e maculam o ordenamento jurídico ${ }^{197}$.

\footnotetext{
${ }^{196}$ SALLES, Carlos Alberto de. Arbitragem em contratos administrativos, cit., p. 174-175.

197 OLIVEIRA, Gustavo Justino de. O setor público é obrigado a buscar soluções para os seus conflitos sem recorrer ao Judiciário: o papel da mediação, conciliação e arbitragem para a atual administração pública brasileira. Disponível em: <http://www.justinodeoliveira.com.br/wpcontent/uploads/2011/10/litigancia-no-setor-publico.pdf>. Acesso em: 10 set. 2014.
} 
Parece mesmo ser uma questão de ordem cultural, influenciada pela construção do Direito Administrativo calcado em uma concepção particular da "supremacia do interesse público". Contudo, o reconhecimento de que o Poder Público se envolve em conflitos é um passo importante para a busca de outras formas de resolução de controvérsia ${ }^{198}$.

\subsection{Interesse público}

"Interesse público" é termo que normalmente vem à tona em qualquer consideração sobre os objetivos da ação administrativa e a composição de conflitos com a Administração, como algo a ser perseguido e preservado. Contudo, o termo é de difícil definição, o que torna algumas considerações sobre o tema um pouco imprecisas.

A própria palavra interesse, como Rodolfo de Camargo Mancuso bem aponta, é plurívoca $^{199}$ e, no campo jurídico, designa questões cuidadas pelo direito com diferentes graus de concreção e abrangência. Tem-se, por exemplo, a diferenciação entre direito coletivo e individual - que é dada, a princípio, pela sua essência -, sendo individual aquele "cuja fruição se esgota no círculo de atuação do seu destinatário"200 e coletivo aquele com notas de indivisibilidade, em que um bem se destina à satisfação de uma necessidade coletiva ${ }^{201}$.

Quanto à concreção, vale retomar a diferenciação de Marçal Justen Filho, para quem o direito subjetivo existe quando o ordenamento jurídico atribui, a um ou mais sujeitos, a possibilidade de exigir uma conduta específica; enquanto o interesse apresenta outra configuração jurídica, pois não envolve a atribuição de um dever determinado, ainda que tutelado pelo direito ${ }^{202}$.

Para Mancuso, o “interesse público" se situaria no campo dos interesses metaindividuais (que transgridem a esfera individual), próximo àqueles interesses tidos como "sociais" ou "gerais" e com diferenças muitos sutis entre as categorias, sendo irrelevante dar-lhes autonomia ${ }^{203}$. O autor aproxima-se de uma ideia de indefinição apriorística do interesse público, ao pontuar que este invoca a presença do Estado-

\footnotetext{
${ }^{198}$ SALLES, Carlos Alberto de. Arbitragem em contratos administrativos, cit., p. 174-175.

${ }^{199}$ MANCUSO, Rodolfo de Camargo. Interesses difusos: conceito e legitimação para agir. 6. ed. São Paulo: RT, 2004, p. 25.

${ }^{200}$ MANCUSO, Rodolfo de Camargo. Interesses difusos, cit., p. 50.

201 Conceito adotado por Mancuso com base em ensinamento de Santoro Passarelli. Cf. MANCUSO, Rodolfo de Camargo. Interesses difusos, cit., p. 57.

202 JUSTEN FILHO, Marçal. Curso de Direito Administrativo. 9. ed. São Paulo: RT, 2013, p. 146-147.

${ }^{203}$ MANCUSO, Rodolfo de Camargo. Interesses difusos, cit., p. 36.
} 
legislador ou do Estado-administrador em ações concretas de arbitramento de diversos interesses presentes, coletivos ou individuais, cabendo à Lei ou à Constituição a definição da competência para tal arbitramento ${ }^{204}$. Acrescentaríamos a essa tentativa conceitual as ações do Estado-juiz, a quem muito é dado decidir sobre o conteúdo do interesse público.

A ideia de indefinição do conteúdo do "interesse público" é corrente na literatura sobre o tema. Para José Eduardo Faria, o interesse público é um princípio, e não uma regra. A regra é clara quanto ao comando normativo que pretende dar, até porque haveria maior consenso social sobre a aceitação de seu conteúdo. Os princípios, por sua vez, apresentam uma textura aberta e flexível: são mais ambíguos, difusos e têm como objetivo auferir lealdade e criar elasticidade ao sistema jurídico, permitindo que se molde em situações nas quais o consenso não é claro. Deste modo, faz-se com que o sistema jurídico seja aceito como funcional e, ao mesmo tempo, com capacidade de transformação no tempo.

O uso do princípio - e isto se revela especialmente verdadeiro no caso de "interesse público" - é, segundo o autor, proposital: em um contexto social instável, de dinamismo social, atá-lo por meio de normas (técnica dependente de contextos estáveis) pode não funcionar e, assim, o legislador se vê obrigado a fazer uso dos princípios para regular, retoricamente, as situações instáveis ${ }^{205}$.

Ainda assim, segundo Rodolfo de Camargo Mancuso,

\footnotetext{
"Não se deve, todavia, ceder ao argumento de que, por conta de os conceitos vagos ou indeterminados criarem zonas cinzentas no ordenamento positivo, ficaria o intérprete desonerado de tentar imprimir concreção conceitual a tais expressões, inclusive para viabilizar as decisões que tenham que ser prolatadas nos casos concretos em que tais expressões têm incidência.

O interesse público, um dos standards jurídicos mais refratários à redução conceitual, também acabou definido na Lei 9.784/99 ("regula o processo administrativo no âmbito da administração pública federal") restando positivado por um critério finalístico: "o atendimento a fins de interesse geral, vedada a renúncia total ou parcial de poderes ou competência, salvo autorização em lei" (art. 2. ${ }^{\circ}$, par. ún., II)"206.
}

Existe hoje uma equivocidade sobre o termo "interesse público", que é utilizado para designar os interesses indisponíveis dos particulares e da sociedade, interesses sociais,

\footnotetext{
${ }^{204}$ MANCUSO, Rodolfo de Camargo. Interesses difusos, cit., p. 31-33.

${ }^{205}$ FARIA, José Eduardo. A definição de interesse público. SALLES, Carlos Alberto de (org.). Processo civil e interesse público: o processo como instrumento de defesa social. São Paulo: RT, 2003, p. 79-90, p. 79-80.

206 MANCUSO, Rodolfo de Camargo. O plano piloto de conciliação em segundo grau de jurisdição, do Egrégio Tribunal de Justiça de São Paulo e sua possível aplicação aos feitos da Fazenda Pública. Revista dos Tribunais, n. 820, p. 11-49, fev./2004, p. 37.
} 
coletivos, difusos e, como se vê correntemente, os interesses ligados à gestão da coisa pública.

No entanto, por ser um termo tão recorrente na fundamentação de decisões administrativas, judiciais, na doutrina e, sobretudo, na discussão sobre a utilização dos meios consensuais pela Administração Pública (ao se falar em sua indisponibilidade), é importante buscar algumas delimitações ao tema e tentar atingir algum sentido para a sua operação.

Marçal Justen Filho apresenta uma primeira saída, que é a de conceituação negativa. $\mathrm{O}$ interesse público não se confunde (i) com o interesse do aparato administrativo, enquanto organização, como as prerrogativas para conveniência de seu funcionamento - o quê poderia ser enquadrado como interesse público "secundário" -, e (ii) com o interesse egoístico dos agentes públicos, que continuam sendo tidos como interesses privados, para que não ocorra, por exemplo, um injusto tratamento tributário diverso para agentes públicos ${ }^{207}$.

Outras rejeições colocadas pelo autor são: (i) não se confunde com o somatório dos interesses individuais, pois nesse caso não haveria qualquer diferença qualitativa, mas apenas quantitativa, entre interesse privado e interesse público; (ii) não se confunde com o interesse da maioria da população, pois essa concepção seria antidemocrática, opressora e avessa a direitos de minorias; (iii) também é insuficiente conceituá-lo como interesse da sociedade, pois esta conceituação ignoraria por completo a dimensão individual, além de causar problemas em relação a quem definiria o que é interesse da sociedade, de modo a representar uma concepção autoritária ${ }^{208}$.

Por fim, o autor completa afirmando que o erro da conceituação de interesse público está em buscar uma homogeneidade, um único interesse público. Em uma sociedade de fragmentação, em que muitas vezes se contrapõe interesses como o da proteção do meio ambiente e o da geração de empregos, o que se pode falar é, no plural, em "interesses públicos"209.

\footnotetext{
207 JUSTEN FILHO, Marçal. Curso de Direito Administrativo, cit., p. 149-150.

208 JUSTEN FILHO, Marçal. Curso de Direito Administrativo, cit., p. 150-152.

209 JUSTEN FILHO, Marçal. Curso de Direito Administrativo, cit., p. 154-155.
} 
Em interessante artigo, Carlos Alberto de Salles, reconhecendo a dificuldade de um conceito genérico de interesse público, traz a discussão ao seu módulo mais operacional: o interesse público na geração de decisões estatais ${ }^{210}$.

No processo civil que envolva discussões sobre "interesse público", o Judiciário decide, entre vários interesses antagônicos, qual será o prevalecente no caso concreto. A matéria em juízo está estritamente ligada às políticas públicas a ela relacionadas. Assim, a decisão deve ser avaliada a partir da sua capacidade de produzir resultados em relação aos objetivos a elas implicados.

A dificuldade da definição de interesse público, para o autor, está na circunstância de que ela deve ser genérica o suficiente para abarcar uma variedade muito grande de situações, e envolve "opções entre uma pluralidade de interesses dispersos pela sociedade e, na maior parte dos casos, excludente" 211.

Dito isso, Salles afirma que a definição do interesse público enquanto decisão estatal engloba uma dose de discricionariedade ${ }^{212}$. O Judiciário mesmo pratica tal discricionariedade quando decide sobre interesses difusos e coletivos. A dificuldade seria dar limites a essa discricionariedade, sob pena de o interesse público carecer de um núcleo mínimo, e que o critério de sua definição seja apenas a competência da autoridade decisória, qualquer que seja o seu conteúdo.

Acrescenta a seu ponto a afirmação de que as decisões sociais incorporam sempre um interesse entre os vários relevantes para a decisão, levando em conta qual das opções de alocação de recursos públicos melhor atende a uma finalidade específica daquela ação ${ }^{213}$. Isso ocorre frequentemente com o Executivo e também com o Legislativo, que ao ponderarem os diversos interesses em jogo, adotam uma política que será consubstanciada numa lei ou regulamento, definindo uma medida distributiva de alocação de recursos ${ }^{214}$.

Assim, para o autor, o interesse público não soluciona a questão de orientação de quais devem ser os comandos jurídicos, mas apresenta aspectos importantes para identificar quanto uma certa decisão é um posicionamento válido e legítimo. Pode-se falar,

${ }^{210}$ Cf. SALLES, Carlos Alberto. Processo Civil de interesse público: uma nova perspectiva metodológica. SUNDFELD, Carlos Ari; BUENO, Cassio Scarpinella. Direito Processual Público: A Fazenda Pública em Juízo. São Paulo: Malheiros, 2000, p. 45-65, p. 52.

211 SALLES, Carlos Alberto. Processo Civil de interesse público: uma nova perspectiva metodológica. SUNDFELD, Carlos Ari; BUENO, Cassio Scarpinella. Direito Processual Público, cit., p. 52.

212 SALLES, Carlos Alberto. Processo Civil de interesse público: uma nova perspectiva metodológica. SUNDFELD, Carlos Ari; BUENO, Cassio Scarpinella. Direito Processual Público, cit., p. 52.

213 SALLES, Carlos Alberto. Processo Civil de interesse público: uma nova perspectiva metodológica. SUNDFELD, Carlos Ari; BUENO, Cassio Scarpinella. Direito Processual Público, cit., p. 53.

214 SALLES, Carlos Alberto. Processo Civil de interesse público: uma nova perspectiva metodológica. SUNDFELD, Carlos Ari; BUENO, Cassio Scarpinella. Direito Processual Público, cit., p. 45-65, p. 53-54. 
nessa linha de pensamento, em uma noção de interesse público puramente processual, baseada no resultado da utilização de mecanismos procedimentais de decisão que são vistos como capazes de expressar a vontade coletiva, distanciando a definição do interesse público de seu conteúdo. A vantagem dessa abordagem processual é que ela põe em destaque a necessidade de se criarem mecanismos capazes de produzir decisões estatais válidas $^{215}$.

Contudo, ainda que seja uma definição que ajuda a dar maior precisão ao conceito, ela apresenta problemas, pois por mais legítimo que seja o procedimento, ele pode gerar decisões realmente equivocadas ou, ainda, que reflitam más preferências sociais. ${ }^{216}$.

$\mathrm{O}$ autor, portanto, propõe encontrar um mínimo denominador comum entre os interesses sociais presentes que permita distinguir o interesse privado daquele pertencente a toda a coletividade; tentando, dessa forma, localizar um parâmetro material, um bem comum. $^{217}$.

Segundo o autor, os bens indivisíveis, com nota de publicidade, e insuscetíveis de apreensão privada (como o meio ambiente), devem ter sua distribuição orientada pela conciliação de interesses de indivíduos e grupos com aqueles pertencentes a toda a coletividade, como solução de demandas conflitantes entre os cidadãos. A priori, não é possível estabelecer um critério para tanto, mas apenas indicar um critério de justiça distributiva que sirva de base à definição de interesse público.

Assim, esse princípio deve ser buscado na indivisibilidade dos bens públicos como tradutora de um critério de justiça distributiva, de forma que todos possam aproveitar igualmente o bem, não permitindo a utilização ou apropriação excludente por um deles. $\mathrm{O}$ restabelecimento da indivisibilidade é o que deve guiar uma decisão (judicial no caso do texto) sobre a definição do interesse público, desfazendo a apropriação individual do bem público $^{218}$.

No entanto, mesmo com parâmetros substanciais, a definição de interesse público ainda depende de um processo, e há a necessidade de se estabelecerem critérios para definir o mais adequado. Deste modo, a via jurisdicional não é a melhor para decidir o

${ }^{215}$ SALLES, Carlos Alberto. Processo Civil de interesse público: uma nova perspectiva metodológica. SUNDFELD, Carlos Ari; BUENO, Cassio Scarpinella. Direito Processual Público, cit., p. 45-65, p. 54-55.

${ }^{216}$ SALLES, Carlos Alberto. Processo Civil de interesse público: uma nova perspectiva metodológica. SUNDFELD, Carlos Ari; BUENO, Cassio Scarpinella. Direito Processual Público, cit., p. 45-65, p. 53-54.

${ }^{217}$ SALLES, Carlos Alberto. Processo Civil de interesse público: uma nova perspectiva metodológica. SUNDFELD, Carlos Ari; BUENO, Cassio Scarpinella. Direito Processual Público, cit., p. 45-65, p. 56-57.

${ }^{218}$ SALLES, Carlos Alberto. Processo Civil de interesse público: uma nova perspectiva metodológica. SUNDFELD, Carlos Ari; BUENO, Cassio Scarpinella. Direito Processual Público, cit., p. 45-65, p. 57-58. 
emprego de verbas públicas, mas se mostra como instituição mais apta para decidir sobre interesse público em situações em que, por falhas de outros processos decisórios, ocorra uma desconsideração de parâmetros básicos de sua formação ${ }^{219}$.

Em síntese, a concepção de Carlos Alberto Salles sobre interesse público é inserida no âmbito de um processo decisório que legitima a enunciação do que constitui o interesse público no caso concreto. Para além do conceito procedimental do interesse público, o autor tenta definir um núcleo material, que seria dado pelo bem comum extraído dos fundamentos do próprio sistema político, e na distribuição de bens indivisíveis segundo um critério de justiça, qual seja o de possibilitar a fruição do bem público igualmente por todos. Essa distribuição se dá por meio de um procedimento adequado ao objetivo social que se pretende e, portanto, é importante estar atento à qualidade de procedimento.

A ideia de arbitramento de diversos interesses, e a rejeição da concepção única e apriorística de interesse público tem tido adesão por parte da doutrina administrativista, como notamos em textos de Maria Sylvia Zanella Di Pietro ${ }^{220}$ e Floriano Azevedo Marques. Segundo este autor, não existe apenas um interesse público, mas interesses públicos, conforme a situação, e

assistimos ao colapso da noção monista de interesse público, da ideia de supremacia do interesse público, da indisponibilidade do interesse público que nos remetia a uma ideia do interesse público único. Cada ação concreta do Poder Público acaba envolvendo uma pluralidade de interesse públicos submetida à sua ação ${ }^{221}$.

Extraímos dessas lições, portanto, que o interesse público é fruto de arbitramento de diversos interesses relacionados a um caso concreto, feito através de bons procedimentos para a definição de seu conteúdo.

\subsection{Indisponibilidade}

\subsubsection{Indisponibilidade, interesse público e bens públicos}

\footnotetext{
219 SALLES, Carlos Alberto. Processo Civil de interesse público: uma nova perspectiva metodológica. SUNDFELD, Carlos Ari; BUENO, Cassio Scarpinella. Direito Processual Público, cit., p. 45-65, p. 59-60.

220 Cf. DI PIETRO, Maria Sylvia Zanella. Discricionariedade administrativa e controle judicial da administração. SALLES, Carlos Alberto de (org.). Processo civil e interesse público: o processo como instrumento de defesa social. São Paulo: RT, 2003, p. 181-190, p. 189.

${ }^{221}$ MARQUES, Floriano Azevedo. Discricionariedade administrativa e controle judicial da administração. SALLES, Carlos Alberto de (org.), cit., p. 191-198, p. 194.
} 
A indisponibilidade dos bens públicos frequentemente aparece como argumento contrário à utilização de meios consensuais, como a conciliação e a mediação, para resolução de conflitos com a Administração.

É corrente na doutrina a afirmação da indisponibilidade do interesse público como característica que decorre do descompasso entre a titularidade do interesse (que é do Estado, da coletividade) e a legitimidade de sua proteção e exercício (que é da Administração). Assim, o interesse do Estado não estaria à livre disposição dos administradores no exercício da função administrativa ${ }^{222}$.

Em primeiro lugar, é importante afastar uma objeção à adoção de meios consensuais pela Administração, mesmo considerando tal objeção: o fato de o interesse público estar frequentemente presente nos conflitos envolvendo a Administração Pública não significa que ela, por um critério subjetivo, não possa engajar em atos de consenso ou de disposição, mas podendo, eventualmente, encontrar óbice em um critério objetivo, ou seja, relativo ao objeto específico envolvido pelo conflito.

Essa diferenciação já foi melhor desenvolvida no âmbito da arbitragem: como a Lei de Arbitragem (Lei n. 9.307/96) permite sua utilização em "litígios relativos a direitos patrimoniais disponíveis" (art. $1^{\circ}$ ), entende-se que a lei estabelece uma arbitrabilidade objetiva, cuja análise do cabimento recai sobre a natureza do litígio. A arbitrabilidade subjetiva, por ser genérica, coincide, na verdade, com a capacidade de contratar (capacidade de direito, na linguagem tradicional), pelo próprio texto da lei, do que a Administração Pública evidentemente não está excluída ${ }^{223}$.

Em outras palavras, a arbitragem é aplicável para definição de direitos privados economicamente apreciáveis e dívidas ${ }^{224}$. Então, temos que um ente não é impedido de engajar em meios alternativos de solução de conflitos simplesmente por integrar a Administração Pública. A análise da possibilidade ou não de adoção de meios consensuais deve recair sobre o objeto da controvérsia.

Para Carlos Alberto de Salles, não existe uma indisponibilidade ampla e geral em relação aos bens e interesses públicos. Existem, sim, certos condicionamentos ${ }^{225}$. O autor

\footnotetext{
${ }^{222}$ Nesse sentido, cf.: MELLO, Celso Antônio Bandeira de. Curso de Direito Administrativo. 30. ed., São Paulo: Malheiros, 2013. p. 76-77.

${ }^{223}$ GLEBER, Eduardo. A solução de controvérsias em contratos de parceria público-privada. Revista de Arbitragem e Mediação, São Paulo, Revista dos Tribunais, n. 2, p. 60-73, mai./ago. 2004, p. 61.

${ }^{224}$ MORAES, Luiza Rangel de. Arbitragem e agências reguladoras. Revista de Arbitragem e Mediação, São Paulo, Revista dos Tribunais, n. 2, p. 74-89, mai./ago. 2004, p. 78.

${ }^{225}$ SALLES, Carlos Alberto de. A arbitragem na solução de controvérsias contratuais da administração pública, cit., p. 408.
} 
critica a expansão indiscriminada da indisponibilidade do interesse público para toda e qualquer relação jurídica que envolva a Administração Pública, o que ocasiona conclusões equivocadas quanto à impossibilidade de qualquer transação no âmbito administrativo. Salienta o autor, na mesma linha já exposta, que a indisponibilidade de qualquer bem ou interesse não decorre do simples fato de ele pertencer à Administração Pública. Não é o elemento subjetivo que determina a indisponibilidade do bem ${ }^{226}$.

Dessa forma, é importante distinguir sobre o quê, exatamente, recai a indisponibilidade. Sobre tal questão, Salles faz uma análise bastante proveitosa ao presente estudo, explicando que há diversas manifestações do termo "indisponibilidade" para caracterizar situações e efeitos diversos.

A indisponibilidade, segundo o autor, é uma relação entre bem e sujeito, em que é vedada a alteração de titularidade do bem. No âmbito dessas relações, a disponibilidade é a regra e a indisponibilidade é a exceção. Há, contudo, bens indisponíveis por sua própria natureza, como os direitos de personalidade (integridade física, por exemplo) ou direitos essencialmente coletivos. Trata-se de uma indisponibilidade material, que decorre da qualidade do próprio bem ${ }^{227}$.

A indisponibilidade tem ainda a vertente normativa: diz-se indisponível aquela norma que não pode ser afastada. A dicotomia, na verdade, é mais comumente tratada pelas expressões "norma cogente" em contraposição a "norma dispositiva". A “indisponibilidade" visa proteger a efetividade da norma. Quanto à Administração Pública, em muitas das situações em que se levanta a questão da indisponibilidade, se está a tratar, na verdade, da indisponibilidade normativa, ou seja, da impossibilidade de se afastarem determinadas normas ${ }^{228}$. Podemos mencionar, como exemplo, regras de competência interna à Administração, que não podem ser afastadas a não ser que exista outra regra de delegação.

A indisponibilidade material, segundo o autor, é exceção dentro da Administração Pública. Se assim não fosse, não poderia a Administração, a qualquer momento, alienar seus bens ou, ainda, efetuando gastos públicos sem qualquer contrapartida (como ocorre no caso de concessão de um benefício assistencial). A indisponibilidade recairia, por exemplo,

\footnotetext{
${ }^{226}$ SALLES, Carlos Alberto de. A arbitragem na solução de controvérsias contratuais da administração pública, cit., p. 410.

${ }^{227}$ SALLES, Carlos Alberto de. A arbitragem na solução de controvérsias contratuais da administração pública, cit., p. 411.

${ }^{228}$ SALLES, Carlos Alberto de. A arbitragem na solução de controvérsias contratuais da administração pública, cit., p. 413.
} 
em bens absolutamente coletivos, como um atributo ambiental ou um bem cultural. O que se cogita é a disponibilidade condicionada por normas ou, ainda, simples impossibilidade de afastamento de regras ${ }^{229}$.

Confunde-se, muitas vezes, o regramento de disponibilidade dos bens públicos com a sua "indisponibilidade" ou, ainda, com a indisponibilidade ampliada para quaisquer relações em que um ente que compõe a Administração Pública faça parte. Bens públicos não são indisponíveis, segundo o autor. Pelo contrário, são objeto de disposição a todo o momento. Os bens públicos sujeitam-se, em verdade, a um regime de disponibilidade condicionada, em que determinadas regras materiais e processuais devem ser respeitadas $^{230}$. Parecem se aproximar, portanto, da indisponibilidade normativa de que se tratou antes ${ }^{231}$.

Todavia, ainda resta compreender a expressão "indisponibilidade do interesse público". O autor aponta que esta "não representa mais que a vinculação das ações administrativas aos interesses maiores do Estado, significando a obrigatoriedade desses

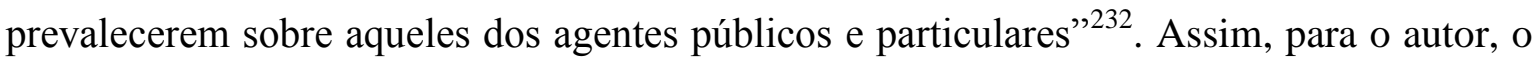
que se deve guardar é sempre o vínculo de interesse entre a ação administrativa e a finalidade pública. Portanto, sugere que em vez de se falar em "indisponibilidade", seja utilizado o termo "vinculação ao interesse público", sem deixar de lado a dificuldade de se compreender o que é "interesse público" em cada caso concreto.

Essa reconstrução do conceito, pelo seu aclaramento e também pela simples alteração nominal, apesar de ser uma visão nova e pouco sedimentada em nossa doutrina, parece adequada e útil, teórica e praticamente, por dois motivos: (i) desmonta a ideia falsa de que quaisquer bens e interesses públicos não podem ser objeto de disposição, ou negociação, ou transação; (ii) reforça a ideia de que qualquer atividade administrativa, ainda que envolvendo disposição, está vinculada necessariamente à finalidade pública.

\footnotetext{
${ }^{229}$ SALLES, Carlos Alberto de. A arbitragem na solução de controvérsias contratuais da administração pública, cit., p. 413.

${ }^{230}$ SALLES, Carlos Alberto de. A arbitragem na solução de controvérsias contratuais da administração pública, cit., p. 416.

${ }^{231}$ Até mesmo os particulares, no pleno gozo de sua capacidade civil, têm a disponibilidade de seus interesses, bens e direitos condicionada e limitada, não se podendo falar em "disponibilidade ampla". Notese, por exemplo, que o esposo não possa alienar ou onerar bens imóveis sem a autorização de sua esposa (art. 1.647 do Código Civil).

${ }^{232}$ SALLES, Carlos Alberto de. A arbitragem na solução de controvérsias contratuais da administração pública, cit., p. 414.
} 


\subsubsection{Interesse público primário e interesse público secundário?}

É corrente, na literatura pesquisada, a classificação do interesse público como primário ou secundário. Tal dicotomia encontra algumas variações, sendo dito que o “interesse público primário" seria aquele concernente aos fins do Estado, enquanto o "secundário" diria respeito a assuntos de Governo ${ }^{233}$. No entanto, também se entende o “interesse público primário" como o complexo de interesses prevalecentes na coletividade e o "interesse público secundário" como aquele da Administração como sujeito jurídico em si mesmo ${ }^{234}$. É mais utilizada, contudo, esta segunda concepção aqui apresentada.

Exemplo dado por Rodolfo de Camargo Mancuso demonstra como esses interesses podem vir a embate: quando o Administrador, sem uma razão plausível, constrói um metrô subterrâneo, quando o de superfície cumpriria a mesma finalidade com custo menor, a obra poderia ter atendido ao interesse do governo ou do ente político, mas distanciou-se do interesse público primário, que coincide com a opção de gestão mais eficiente do patrimônio público $^{235}$.

Essa distinção é frequentemente invocada para afirmar que o interesse público primário é indisponível e intransigível, enquanto o secundário pode ter autorizada a sua transação.

No âmbito da arbitrabilidade, é corrente a afirmação de que o interesse público primário, destinado a satisfazer os propósitos finalísticos do Estado, é sempre, por tal motivo, indisponível e impassível de arbitragem. Por outro lado, os interesses secundários ou instrumentais, destinados a "apenas" permitir a realização dos primários por meio da formação de relações patrimoniais, seriam passíveis de atos de negociação e de disposição, pois a Administração estaria a praticar atos de gestão e não atos de império, próprios e privativos do Estado (como exação tributária ou exercício do poder de polícia) ${ }^{236} 237$.

${ }^{233}$ VOLPI, Elon Kaleb Ribas. Conciliação na Justiça Federal: A indisponibilidade do interesse público e a questão da isonomia. Revista da PGFN. Brasília, PGFN, ano 1, n. 2, p. 139-164, 2011, p. 149.

${ }^{234}$ TALAMINI, Eduardo. A (in)disponibilidade do interesse público: consequências processuais. Revista de Processo, São Paulo, RT, n. 128, p. 59-77, out./2005, p. 61.

${ }^{235}$ MANCUSO, Rodolfo de Camargo. O plano piloto de conciliação em segundo grau de jurisdição, do Egrégio Tribunal de Justiça de São Paulo e sua possível aplicação aos feitos da Fazenda Pública. Revista dos Tribunais, n. 820, p. 11-49, fev./2004, p. 40.

${ }^{236}$ GLEBER, Eduardo. A solução de controvérsias em contratos de parceria público-privada. Revista de Arbitragem e Mediação, São Paulo, Revista dos Tribunais, n. 2, p. 60-73, mai./ago. 2004, p. 63.

${ }^{237}$ Confira-se, ainda, parecer de Eros Grau que adota tal critério: GRAU, Eros. Da arbitrabilidade de litígios envolvendo sociedades de economia mista e da interpretação de cláusula compromissória. Revista de Direito Bancário e Mercado de Capitais. São Paulo, RT, n. 18, p. 395-405, out./dez. 2002. 
Essa distinção tem origem em texto de Renato Alessi, publicista italiano que diferenciou o verdadeiro interesse público - de natureza coletiva e que deveria ser o objeto da ação administrativa - do interesse da administração em si mesma, o qual é apenas mais um interesse público secundário na sociedade, como agente racional que pretende minimizar seus custos e aumentar seu capital, por meio, por exemplo, do menor pagamento possível a seus funcionários e do aumento de impostos. Haveria, portanto, oposição entre o interesse da Administração e o interesse público coletivo - objetivando este colocar o máximo de pessoas na melhor condição possível e de ser submetida a uma carga tributária menor, no exemplo utilizado.

Em suas palavras:

interesse pubblico non è nient'altro che l'interesse collettivo primario, considerato come oggetto di diretta tutela dell'azione amministrativa, mentre l'interesse dell'amministrazione in quanto soggetto giuridico a sè stante, non rappresenta se non uno degli interessi secondari esistenti nel gruppo sociale.

(...)

l'interesse secondario dell'amministrazione porterebbe la stessa a pagare i propri impiegati il meno possibile, e ad aumentare al massimo possibile le imposte, al fine di aumentare al massimo le proprie disponibilità patrimoniali: per contro, l'interesse pubblico (collettivo) esige, rispettivamente, che gli impiegati siano pagati in modo sufficiente a metterli nelle migliori condizione acciochè le loro prestazioni siano efficaci, ed i citadini non siano gravati di imposte oltre una data misura ${ }^{238}$.

Depreende-se do texto que a distinção por ele originada guarda alguns problemas. O primeiro deles é que ela parte de uma ideia de que Administração se comporta como um agente econômico, destinado à acumulação de receitas, quando, na verdade, já vimos que a concepção moderna de Administração é instrumental e finalística, ou seja, as atividades administrativas só fazem sentido se servirem de instrumento para finalidades públicas e promoção de direitos fundamentais. Aparentemente, é distinção cunhada em época diversa, sob outras circunstâncias históricas e sob outro tipo de Administração.

Atualmente, em que se identifica o interesse público secundário com o interesse fazendário, a distinção é útil para evidenciar à própria Administração que suas atividades instrumentais (interesse público secundário, naquela concepção) não devem se distanciar

238 ALESSI, Renato. Sistema istituzionale del diritto amministrativo italiano. Milano: Giuffrè, 1953. p. 152-153, rodapés 2 e 3. Tradução livre: "interesse público não é nenhum outro senão o interesse coletivo primário, considerado como objeto de tutela direta da ação administrativa, enquanto o interesse da administração enquanto sujeito jurídico de direito próprio, não representa se não um interesse secundário existente no grupo social. (...) $\mathrm{O}$ interesse secundário da administração seria de pagar a seus empregados o menos possível, e de aumentar ao máximo possível o imposto, a fim de aumentar sua própria disponibilidade de patrimônio: pelo contrário, o interesse público (coletivo) exige, respectivamente, que os empregados sejam pagos em modo suficiente a colocá-los em melhores condições para que seu desempenho seja eficaz, e os cidadãos não sejam sobrecarregados por impostos sobre uma determinada medida". 
da realização do "bem comum", das finalidades públicas, da promoção dos direitos fundamentais (interesse público primário). É útil, ainda, para identificar, na atuação da administração, se ela se move por um interesse meramente fazendário ou se está tomando a melhor decisão para atendimento do "interesse público primário"239. A distinção entre os interesses primário e secundário também é útil para o controle dos atos do administrador público, como evidencia Mancuso:

não se pode afirmar que o interesse fazendário (público secundário) tenha outra natureza ou seja distinto do interesse público propriamente dito: a Administração Pública tem o poder-dever de realizar a boa gestão da coisa pública e isso implica fazer coincidir ou ao menos aproximar o mais possível as escolhas e a conduta administrativa do sentido básico do que se entende por interesse público.

Quando esse desiderato se frustra, por culpa ou dolo do Administrador, ele se sujeita a ser responsabilizado (.... $)^{240}$.

Contudo, a distinção não é suficiente para distinguir o que é ou não disponível, transacionável e o que pode ou não ser objeto de solução consensual. Há interesses que poderiam ser classificados como "secundários" por Alessi, mas que têm sua disponibilidade tão normativamente condicionada que se tornaria difícil afirmá-los como plenamente transacionáveis. É o caso dos tributos submetidos a condicionamentos do Código Tributário Nacional (Lei n. 5.172/66), como a necessidade de previsão legal expressa para transação (art. 171), e também à Lei de Responsabilidade Fiscal (Lei Complementar n. 101/2000), como condicionar a renúncia de receita (aí incluída a remissão do crédito tributário) à "demonstração pelo proponente de que a renúncia foi considerada na estimativa de receita da lei orçamentária" e a medidas de compensação (art. 14, I e II).

Por outro lado, há interesses classificados como "primários" que são pacificamente submetidos a meios consensuais, como o exemplo dos Termos de Compromisso firmados

\footnotetext{
${ }^{239}$ Nesse sentido, a distinção foi recentemente levantado pelo Superior Tribunal de Justiça para decidir sobre a necessidade ou não da intervenção do Ministério Público como custus legis em ações de reparação de dano causado ao erário, tendo aquela Corte, em julgado de relatoria do Ministro Benedito Gonçalves, concluído que a ação tratava de "interesse público secundário" e não demandava a intervenção ministerial: "A interpretação dessa norma à luz dos arts. 129, inciso I e IX, da Constituição da República, revela que o"interesse público" que justifica intervenção do Ministério Público não está relacionado à simples presença dente público na demanda nem ao seu interesse patrimonial (interesse público secundário ou interesse da Administração). Exige-se que o bem jurídico tutelado coresponda um interesse mais amplo, com espectro coletivo (interesse público primário)" (BRASIL. Superior Tribunal de Justiça. Embargos de divergência em recurso especial n. 1151639-GO. Órgão Julgador: Primeira Seção. Relator: Benedito Gonçalves. J. em: 10/09/2014. DJe em 15/09/2014).

${ }^{240}$ MANCUSO, Rodolfo de Camargo. O plano piloto de conciliação em segundo grau de jurisdição, do Egrégio Tribunal de Justiça de São Paulo e sua possível aplicação aos feitos da Fazenda Pública, cit., p. 40.
} 
no âmbito das Ações Civis Públicas. Assim, não parece ser critério útil para traçar a possibilidade ou não do uso de mecanismos consensuais.

A esse respeito, Juliana Bonacorsi de Palma levanta a seguinte objeção:

O cenário de fragmentação social que enseja uma pluralidade de interesses, que não permite reconhecer a natureza pública ou privada dos interesses levados à Administração para arbitramento ou composição. Assim, não é possível estabelecer o campo da consensualidade com base na dicotomia interesses públicos primários interesses públicos secundários $(\ldots)^{241}$.

Outra distinção que os textos normalmente utilizam para sustentar a possibilidade de utilização de meios privados (arbitragem) e meios consensuais é aquela entre (i) atos de império e (ii) atos de gestão ${ }^{242} 243$. Os primeiros seriam atos "em que a Administração praticava no gozo de prerrogativas de autoridade", como a interdição de um estabelecimento, e os segundos atos "que a Administração praticava sem o uso de poderes comandantes", como a gestão de um serviço público ${ }^{244}$.

Para Juliana Bonacorsi de Palma, o critério também não é adequado para distinguir o que pode e o que não pode ser objeto de solução consensual.

Segundo a autora, tal distinção se origina no Direito Francês com a finalidade de distinguir atos regidos pelo Direito Administrativo e atos regidos pelo Direito Privado para, assim, estabelecer a competência do Conselho de Estado. Transplantada tal noção

\footnotetext{
${ }^{241}$ PALMA, Juliana Bonacorsi de. Atuação administrativa consensual: Estudo dos acordos substitutivos no processo administrativo sancionador, Dissertação (mestrado) - Faculdade de Direito da Universidade de São Paulo (USP), São Paulo, 2009, p. 164.

242 GARCEZ, José Maria Rossani. O Estado, suas agências, as empresas públicas e as sociedades de que participa na arbitragem privada. Recentes progressos. Revista de Arbitragem e Mediação, São Paulo, Revista dos Tribunais, n. 8, p. 101-118, jan./mar. 2006, p. 103.

${ }^{243}$ É nesse sentido, apenas para exemplificação, era a antiga lei de arbitragem peruana: "lãs controvérsias determinadas o determinables sobre lãs cuales lãs partes tienene caultad de libre disposición, así como aquellas relativas a materia ambiental, pudiendo extinguirse respecto de ellas El proceso judicial existente o evitando El que podría promoverse; excepto: (...) 4. Las directamente concernientes a atribuciones o funciones de imperio del Estado, o de personas o entidades de derecho público". A nova Lei Peruana de Arbitragem (Decreto Legislativo n. 1071, de 2008), no entanto, traz redação mais específica, na linha de autorização legal para situações determinadas: Artículo $4^{\circ}$.- Arbitraje del Estado Peruano 1. Para los efectos de este Decreto Legislativo, la referencia a Estado Peruano comprende el Gobierno Nacional, los Gobiernos Regionales, los Gobiernos Locales y sus respectivas dependencias, así como las personas jurídicas de derecho público, las empresas estatales de derecho público, de derecho privado o de economía mixta y las personas jurídicas de derecho privado que ejerzan función estatal por ley, delegación, concesión o autorización del Estado. 2. Las controversias derivadas de los contratos y convenios celebrados entre estas entidades estatales pueden someterse también a arbitraje nacional. 3. El Estado puede someter a arbitraje nacional las controvérsias derivadas de los contratos que celebre con nacionales o extranjeros domiciliados en el país. 4. El Estado puede también someter a arbitraje internacional, dentro o fuera del país, las controversias derivadas de los contratos que celebre con nacionales o extranjeros no domiciliados en el país.5. En caso de actividades financieras, el arbitraje podrá desarrollarse dentro o fuera del país, inclusive con extranjeros domiciliados en el país.

${ }^{244}$ MELLO, Celso Antônio Bandeira de. Curso de Direito Administrativo, cit., p. 433.
} 
para o Direito Administrativo brasileiro, encontraram-se dificuldades, com o passar do tempo, em diferenciar atos de organização administrativa e atos de imperatividade, que repercutem na esfera de direitos dos administrados ${ }^{245}$.

Bandeira de Mello também desqualifica a distinção, entendendo que ela está em desuso por ser inexata e por ter perdido a sua principal função, que é a de estabelecer a responsabilidade do Estado apenas para atos de gestão, excluindo-a no caso de atos de império. $\mathrm{O}$ autor critica a doutrina que invoca a distinção para estabelecer que apenas atos de império são verdadeiramente atos administrativos. Para o autor, mais precisa é a distinção atual de atos regidos por Direito Público e atos regidos por Direito Privado, à qual não são atribuídas as mesmas consequências designadas à distinção entre atos de império e de gestão, como a questão da exclusão da responsabilidade estatal ${ }^{246}$.

Igualmente não é distinção válida para definir se conflitos concernentes aos atos administrativos podem ou não ser dirimidos pela via consensual, tendo em vista que muitas prerrogativas públicas sancionatórias, como aquelas existentes no âmbito de órgãos de controle como a Comissão de Valores Imobiliários e o Conselho Administrativo de Defesa Econômica, hoje podem ser substituídas pela construção de soluções consensuais, como termos de compromisso, ao que se dá o nome de "concertação administrativa", como já visto.

O mais correto seria não limitar a incidência dos meios consensuais de solução de conflitos por um critério dicotômico e, por outro lado, assumir o amplo espaço para composição de interesses pela via consensual, como forma de atendimento inclusive das finalidades públicas; além de verificar, na análise de cada caso, quais são as condicionantes e os limites específicos para a realização da solução consensual.

Dessas limitações trataremos no tópico seguinte e no Capítulo 4.

\subsubsection{A adoção dos meios consensuais de solução de conflitos implica em ato}

\section{de disposição?}

\footnotetext{
245 "Some-se a isso a unidade de jurisdição recepcionada pela Constituição de 1988, o que torna inócua no Brasil a dicotomia atos de gestão - atos de império, há muito já reconhecida pela doutrina administrativista. Tendo em vista essas considerações, é errôneo afirmar que a Administração pode transacionar nas situações que envolvam atos de gestão, enquanto a consensualidade estaria vedada nas hipóteses que ensejem a prática de atos de império pela Administração Pública" (PALMA, Juliana Bonacorsi de. Atuação administrativa consensual, cit., p. 164-165).

${ }^{246}$ MELLO, Celso Antônio Bandeira de. Curso de Direito Administrativo, cit., p. 433.
} 
A "indisponibilidade", ou disponibilidade condicionada, ou, ainda, nos termos da reformulação do item 3.2.1., a vinculação necessária ao interesse público não pode, por si só, representar óbice à adoção de meios consensuais de solução de conflitos.

Um argumento corrente na doutrina consultada para reforçar tal conclusão é o de que a "indisponibilidade" do interesse concernente à Administração Pública não se confunde com sua "intransigibilidade" ou "inegociabilidade". Estas somente existiriam, de fato, naqueles casos em que a Lei expressamente veda, como no caso de ação judicial de improbidade administrativa ${ }^{247}$ (art. $17, \S 1^{\circ}$, da Lei n. 8.429/92).

Os exemplos se proliferam. Rodolfo de Camargo Mancuso nos apresenta os seguintes: os alimentos, que apesar de serem irrenunciáveis, conforme o art. 1.707 do Código Civil, podem ter sua expressão pecuniária e outras características fixadas de forma consensual; os interesses defendidos via ação civil pública que são claramente indisponíveis, mas que podem ser objeto de termo de compromisso quanto à sua forma de proteção; o crédito fiscal que, apesar de aparentar indisponível a princípio, comporta parcelamento, transação e renúncia (ainda que se trate de disponibilidade condicionada); o erário público a princípio é indisponível, mas as desapropriações, pagas com dinheiro público, podem ser feitas de forma amigável ${ }^{248}$.

Para Luciana Moessa de Souza, a confusão entre transigibilidade e indisponibilidade advém de uma leitura incorreta do art. 841, que estabelece que "somente quanto a direitos patrimoniais de caráter privado se permite a transação", norma que apenas se aplicaria à Administração Pública no âmbito das atividades submetidas ao direito privado, nada impedindo que leis administrativas, de direito público, fundamentem a celebração de transações administrativas ${ }^{249}$.

\footnotetext{
${ }^{247}$ Susana Henriques da Costa nos explica porque a improbidade é uma exceção em relação a todas as demais formas de defesa de interesses metaindividuais. A resposta estaria no fato de que a ação de improbidade envolve o direito de punir do Estado, sendo hipótese de jurisdição necessária: "Na verdade, uma leitura mais atenta do art. 12 da LIA responde a essa pergunta. Lá estão previstas uma série de sanções restritivas de direito e pecuniárias ao agente ímprobo. Percebe-se, portanto, que a Lei de Improbidade Administrativa prevê não somente a tutela aos interesses por ela tratados, mas também a punição do réu, nos casos de procedência da demanda. Estão em jogo, portanto, nas ações de improbidade, não somente questões de direito metaindividuais do patrimônio público e da probidade administrativa, mas também o direito de punir do Estado. O direito de punir do Estado, por sua vez, segundo nosso ordenamento jurídico, somente se efetiva mediante decisão judicial, não havendo espaço para acordo entre as partes. Trata-se de hipótese de jurisdição voluntária (COSTA, Susana Henriques da. Comentário ao art. $5^{\circ}$ da Lei de Ação Civil Pública. (coor.). Comentários à Lei de Ação Civil Pública e à Lei de Ação Popular. São Paulo: Quartier Latin, 2006, p. 425).

${ }^{248}$ MANCUSO, Rodolfo de Camargo. O plano piloto de conciliação em segundo grau de jurisdição, do Egrégio Tribunal de Justiça de São Paulo e sua possível aplicação aos feitos da Fazenda Pública, cit., p. 38.

${ }^{249}$ SOUZA, Luciana Moessa de. Meios consensuais de solução de conflitos envolvendo entes públicos. Belo Horizonte: Fórum, 2012, p. 170.
} 
Além do art. 841, vários dispositivos no Código de Processo Civil estão imbuídos da ideia de que apenas direitos patrimoniais indisponíveis são passíveis de transação e, portanto, de composição consensual (em uma associação incorreta, como veremos). Notese o art. 447, que dispõe que "quando o litígio versar sobre direitos patrimoniais de caráter privado, o juiz, de ofício, determinará o comparecimento das partes ao início da audiência de instrução e julgamento" e "tentará conciliar as partes". A redação leva a crer que apenas em causas que versem sobre direito patrimonial privado é que o juiz determinará a realização de audiência de conciliação. O art. 331 do CPC, por sua vez, determina a realização da audiência preliminar em caso de "direitos que admitam transação".

A conjugação desses dispositivos deflagra um ambiente em que dificilmente se designam audiências de conciliação ou audiências preliminares quando uma das partes é ente público ${ }^{250}$, o que foi confirmado na pesquisa empírica realizada para esta dissertação. Este ambiente, por sua vez, decorre de uma interpretação absolutamente literal dos dispositivos que contraria todo o sistema já formado em torno do fomento aos meios consensuais de solução de $\operatorname{conflitos}^{251}$. Segundo Rodolfo de Camargo Mancuso, na leitura de tais dispositivos, “[a] oração 'direitos que admitem transação', não pode ser vinculada ou ficar subordinada à expressão 'direitos disponíveis', dado que uma circunstância não induz necessariamente a outra" ${ }^{252}$.

Além da discussão sobre a correção da ideia genérica de "indisponibilidade" do interesse público, mesmo se entendermos viável tal conceito se traduzirmos como "renúncia", ainda assim teremos que a utilização de meios consensuais de solução de conflitos não significa, de forma geral, abrir mão de parte de um interesse.

Por isso, muitos defendem a utilização de meios consensuais para a proteção integral de direitos tidos como absolutamente indisponíveis (ou irrenunciáveis, em uma linguagem mais clara).

Rodolfo de Camargo Mancuso afirma que, mesmo em se tratando desses direitos, a audiência preliminar deve ser agendada obrigatoriamente, pois eles ainda são passíveis de autocomposição. Para o autor, o que importa é a preservação do núcleo essencial do direito

\footnotetext{
${ }^{250}$ Cf. BRANDÃO, Marcella Araújo da Nova. A consensualidade e a administração pública em juízo. Dissertação (mestrado) - Escola de Direito da Fundação Getúlio Vargas, Rio de Janeiro, 2009, p. 54.

${ }^{251}$ MANCUSO, Rodolfo de Camargo. O plano piloto de conciliação em segundo grau de jurisdição, do Egrégio Tribunal de Justiça de São Paulo e sua possível aplicação aos feitos da Fazenda Pública, cit., p. 40.

${ }^{252}$ MANCUSO, Rodolfo de Camargo. O plano piloto de conciliação em segundo grau de jurisdição, do Egrégio Tribunal de Justiça de São Paulo e sua possível aplicação aos feitos da Fazenda Pública, cit., p. 41.
} 
irrenunciável; havendo, contudo, a possibilidade de se negociar quanto a aspectos instrumentais $^{253}$.

O conceito legal de transação, que envolve "concessões recíprocas", também é fator que atrapalha a correta compreensão de como se operam os meios consensuais, por pressupor que sempre envolveria uma renúncia.

Por isso, Susana Henriques da Costa destaca uma corrente que entende que o Termo de Compromisso firmado no âmbito de ação civil pública não pode ser considerado transação, sendo inadmissível qualquer concessão sobre um direito metaindividual. Contudo, em correta compreensão, a autora afirma que não importa se chamar de transação ou não: o que o Termo de Compromisso deve considerar é que não é possível ao legitimado extraordinário abrir mão do interesse metaindividual ou de parcela dele (eis uma condicionante), devendo, na verdade, utilizar o meio consensual como uma forma de proteção integral, na qual podem ser negociados as formas, prazos e detalhes de como se dará essa proteção ${ }^{254}$.

É preciso ficar claro que a submissão de um conflito a um mecanismo extrajudicial não implica renúncia ou disposição dos direitos em relação aos quais controvertem as partes. Ao contrário, esses mecanismos significam um recurso destinado à sua proteção ou efetivação ${ }^{255}$.

Além dos casos em que os meios consensuais podem ser utilizados para a proteção integral de determinado interesse, há ainda casos em que sua utilização não implica, de forma alguma, "disposição" ou "renúncia" de direitos, dos quais trataremos a seguir.

\subsubsection{A indisponibilidade não significa necessária submissão ao processo} judicial

Pela via dos meios consensuais de solução de conflitos, como a conciliação ou mesmo a negociação direta, é possível aclarar pontos sobre questões fáticas e jurídicas envolvidas no conflito. Nada impede que um meio consensual veicule uma revisão de uma

\footnotetext{
${ }^{253}$ MANCUSO, Rodolfo de Camargo. O plano piloto de conciliação em segundo grau de jurisdição, do Egrégio Tribunal de Justiça de São Paulo e sua possível aplicação aos feitos da Fazenda Pública, cit., p. 41.

${ }^{254}$ COSTA, Susana Henriques da. Comentário ao art. $5^{\circ}$ da Lei de Ação Civil Pública. (coor.). Comentários à Lei de Ação Civil Pública e à Lei de Ação Popular, cit., p. 424 ${ }^{255}$ SALLES, Carlos Alberto de. A arbitragem na solução de controvérsias contratuais da administração pública, cit., p. 419.
} 
decisão administrativa ou mesmo um reconhecimento de direitos em consonância com a legalidade, sem que isso implique disponibilidade ou renúncia.

Isso parte da ideia de que a disposição condicionada ou a irrenunciabilidade do interesse público não coincide necessariamente com a posição assumida inicialmente pela Administração Pública diante de uma controvérsia.

Em interessante digressão sobre o tema, Eduardo Talamini afirma que, em juízo, ou mesmo antes do ingresso de uma ação judicial, se a Administração Pública percebe que a outra parte tem razão em sua pretensão, não possui a obrigatoriedade de prosseguir litigando. $\mathrm{O}$ autor identifica o interesse público não com a posição assumida pela Administração que se lhe afigurar mais conveniente, mas com a própria submissão à lei e com o atendimento das pretensões dos cidadãos quando estas estiverem corretas. Pelo contrário, deve se submeter à pretensão de que, estando embasada em lei (em uma concepção sistêmica), é reconhecida pela Administração, por atenção aos próprios princípios da legalidade (uma vez que submeter-se à pretensão correta é, em última instância, atender à lei) e da moralidade administrativa.

Ainda segundo o autor, tais composições sequer necessitam ser submetidas ao Judiciário, o que pode ser realizado em fase pré-processual ou mesmo extraprocessualmente. Nesses casos, há a dispensa de autorização legal, pois ao reconhecer a pretensão correta, mesmo administrativamente, a Administração já está se submetendo à $1 \mathrm{ii}^{256}$.

Fazemos apenas uma reparação à afirmação do autor: não obstante não haja necessidade de autorização legal, o sujeito competente para o reconhecimento da pretensão do administrado deve estar devidamente identificado por atos normativos da pessoa jurídica de direito público, até mesmo para assegurar ao administrado a lisura do procedimento adotado. É tema que trataremos com mais profundidade adiante.

E também conforme as considerações do autor, são citados dois exemplos interessantes de questões que podem ser compostas ainda em via pré-processual: o reequilíbrio econômico-financeiro dos contratos travados com a Administração Pública e a indenização de danos causados com responsabilidade da Administração. Em ambas as

\footnotetext{
${ }^{256}$ TALAMINI, Eduardo. A (in)disponibilidade do interesse público: consequências processuais, cit., p. 59-
} 62. 
situações a Administração pode, administrativamente, resolver em consenso com o cidadão $^{257}$.

Para o autor, os atos de reconhecimento, pela Administração, de que ela não tem razão em um determinado conflito - seja transacionando em relação à sua posição inicial, seja submetendo-se inteiramente ao direito (frise-se: reconhecido pela Administração) do particular, encontram-se dentro dos parâmetros da legalidade.

Trata-se, na verdade, de conduta que se impõe por respeito à legalidade e à moralidade administrativa, ambas tomadas como princípios de atuação da Administração Pública com assento constitucional (art. 37, caput, CF). Insistir em se opor ao direito do particular por simples invocação do princípio da indisponibilidade gera, segundo o autor, “reprovação qualificada (justamente por constitucional) à postura desleal da Administração Pública. Se a Administração constata que a posição jurídica do particular é correta, não lhe é dado valer-se de artifícios ou subterfúgios para subtrair-se ao cumprimento do dever ali extraível" 258.

A revisão da posição inicial da Administração Pública em uma situação de controvérsia, para adequação à legalidade, conta com suporte normativo que a explicita. $\mathrm{O}$ art. 53 da Lei 8.974/99 (Lei do Processo Administrativo) dispõe que "[a] Administração deve anular seus próprios atos, quando eivados de vício de legalidade, e pode revogá-los por motivo de conveniência ou oportunidade, respeitados os direitos adquiridos". A possibilidade de revisão dos atos administrativos já era prevista nas antigas Súmulas $346^{259}$ e $473^{260}$ do STF.

Decorre, de tais assunções uma corrente doutrinária que afirma ter a Administração Pública o dever de avaliar a possibilidade de transigir em todas as questões controversas e, mais que isso, o dever de transigir em determinados casos.

Assim, para Luciana Moessa de Souza, o advogado público a frente de um processo judicial deve efetuar uma apuração criteriosa dos fatos relevantes, analisar a doutrina e a jurisprudência existentes sobre o assunto e ponderar os riscos envolvidos em eventual

\footnotetext{
${ }^{257}$ TALAMINI, Eduardo. A (in)disponibilidade do interesse público: consequências processuais, cit., p. 6061.

${ }^{258}$ TALAMINI, Eduardo. A (in)disponibilidade do interesse público: consequências processuais, cit., p. 6061.

${ }^{259}$ STF Súmula no 346 - 13/12/1963: Administração Pública - Declaração da Nulidade dos Seus Próprios Atos. A administração pública pode declarar a nulidade dos seus próprios atos.

${ }^{260}$ STF Súmula no 473 - 03/12/1969: Administração Pública - Anulação ou Revogação dos Seus Próprios Atos. A administração pode anular seus próprios atos, quando eivados de vícios que os tornam ilegais, porque deles não se originam direitos; ou revogá-los, por motivo de conveniência ou oportunidade, respeitados os direitos adquiridos, e ressalvada, em todos os casos, a apreciação judicial.
} 
transação. Se, a partir de tal análise, concluir-se de forma inarredável que a pretensão contra o Poder Público constitui efetivo direito, a Administração tem o dever de reconhecer, parcial ou totalmente o direito do autor. Para a autora, nesses casos, o reconhecimento é ato vinculado, visto que exigido pela ordem jurídica ${ }^{261}$.

É inviável, portanto, estabelecer previamente uma restrição ao ato de transacionar por parte da Administração Pública. O fato de que os direitos em jogo são indisponíveis gera à Administração um munus de atuação em favor do interesse público, no sentido de que não pode abrir mão de protegê-lo. Isso não corresponde, contudo, à ideia de que o direito indisponível não é transigível, não só pelos exemplos já citados acima - sobre direitos indisponíveis, especialmente em direito das famílias, porém transacionáveis e aparáveis -, como pela própria função estatal de proteção da legalidade e da moralidade públicas como imperativo constitucional.

De todas essas considerações também decorre que as relações de Direito Público, ainda que controvertidas, não precisam ser submetidas necessariamente à intervenção judicial $^{262}$. Para Rodolfo de Camargo Mancuso, a Administração tem o poder-dever de resolver os seus conflitos de per se, utilizando seu poder de polícia e seu autogoverno ${ }^{263}$.

A necessidade de submissão ao Poder Judiciário é exceção, ou seja, apenas se dá quando a composição do conflito não puder se dar sem a intervenção judicial, como os casos que envolvem estado da pessoa ou a persecução penal. Nesses casos, há indisponibilidade da solução jurisdicional. Eduardo Talamini bem ressalta que "os direitos eventualmente existentes podem e devem ser cumpridos independentemente de instauração de um processo judicial. Vale dizer: a ação judicial e a intervenção jurisdicional, em princípio, não são necessárias nas relações de direito público" ${ }^{264}$. Em âmbito não criminal, as exceções ficam por conta, a exemplo, do art. 95, I, da Constituição Federal e dos arts. 12, parágrafo único, 16, 18 e 20 da Lei n. 8.429/92.

Carlos Alberto de Salles ainda ressalta que, em nosso sistema, a obrigatoriedade da utilização da via judicial (a que o autor chama de "reserva de jurisdição") é exceção, existente apenas para as ditas "ações necessárias"; hipóteses nas quais "o processo judicial é necessário para produção de um efeito jurídico válido", “inviabilizando, dessa maneira, a

${ }^{261}$ SOUZA, Luciane Moessa de. Meios consensuais de solução de conflitos envolvendo entes públicos, cit., p. 175-179.

${ }^{262}$ TALAMINI, Eduardo. A (in)disponibilidade do interesse público: consequências processuais, cit., p. 6162.

${ }^{263}$ MANCUSO, Rodolfo de Camargo. O plano piloto de conciliação em segundo grau de jurisdição, do Egrégio Tribunal de Justiça de São Paulo e sua possível aplicação aos feitos da Fazenda Pública, cit., p. 45.

${ }^{264}$ TALAMINI, Eduardo. A (in)disponibilidade do interesse público: consequências processuais, cit., p. 62. 
utilização de mecanismos de consenso". São, dentre outras, principalmente ações ligadas à jurisdição voluntária, como a anulação de casamento, interdição de incapaz e extinção de poder familiar. ${ }^{265}$ É inconcebível, por exemplo, que por acordo extrajudicial uma pessoa se dê por interditada e constitua alguém como seu curador.

Ressalta o autor, ainda, que a "reserva de jurisdição" não se relaciona, necessariamente, com a indisponibilidade do bem jurídico objeto de disputa ${ }^{266}$, o que leva a concluir que, para que se decida uma situação controversa que pode resultar em deslocamento de patrimônio em desfavor da Administração, não é necessária uma ação judicial para que o declare.

Na mesma linha, não é possível falar em um “dever de litigar” da Administração quando reconhece o direito do administrado, mesmo já estando a questão judicializada. Em juízo, defende-se que tanto quanto o dever de se submeter à legalidade, a Administração tem o dever de mitigar os prejuízos que sofreria com uma derrota judicial. Quando, desde cedo, a Administração se propõe a compor o conflito, há vantagens que podem ser negociadas, como, por exemplo, um parcelamento, um prazo ou, ainda, a dispensa de honorários $^{267}$.

\subsection{Meios adjudicatórios de solução de conflitos}

Lon Fuller, um dos principais autores a identificar diferentes processos para a resolução de conflitos, explica a adjudicação como "a social process of decision which assures to the affected party a particular form of participation, that of presenting proof and arguments for a decision in his favor" ${ }^{268}$.

A definição de Fuller se baseia na forma como o processo é conduzido. A tal definição, Frank Sander acrescentou outras características, como a participação de um terceiro com força coercitiva (preferimos falar em "força impositiva"), o resultado "ganha

\footnotetext{
${ }^{265}$ SALLES, Carlos Alberto de. A arbitragem na solução de controvérsias contratuais da administração pública, cit., p. 136-137.

${ }^{266}$ SALLES, Carlos Alberto de. A arbitragem na solução de controvérsias contratuais da administração pública, cit., p. 138.

${ }^{267}$ TALAMINI, Eduardo. A (in)disponibilidade do interesse público: consequências processuais, cit., p. 65. ${ }^{268}$ FULLER, Lon Luvois. Collective bargaining and the arbitrator. Wisconsin Law Review, Wisconsin, $n$. 18, p. 3-47, 1963, p. 19. Tradução livre: "um processo decisório social que assegura à parte afetada uma forma particular de participação, qual seja a apresentação de provas e argumentos para uma decisão em seu favor".
} 
ou perde" e a tendência de a decisão focar apenas na questão imediatamente posta ao julgador em vez da relação subjacente entre as partes ${ }^{269}$.

Os meios adjudicatórios não se resumem ao processo judicial. Sander já incluía entre eles a arbitragem e o processo administrativo ${ }^{270}$. A tônica que hoje é dada aos meios adjudicatórios é a força impositiva da decisão dada por terceiro, a quem é conferido o poder de decidir. A definitividade e a coercitividade não são notas necessárias do meio adjudicatório: a arbitragem, por exemplo, resulta em decisões dotadas de definitividade, mas o árbitro não pode, por si só, impor a decisão, por carecer de coercitividade, devendo o interessado valer-se do Poder Judiciário para o seu cumprimento. O processo administrativo que se desenrola perante órgãos como as agências reguladoras, ainda que lhe seja atribuído o poder de decisão, terá seu resultado sujeito a ampla revisão judicial; carecendo, portanto, de definitividade ${ }^{271}$.

${ }^{269}$ SANDER, Frank E. A. Varieties of Dispute Processing. LEVIN, Leo A.; WHEELER, Russell R (edit.). The Pound Conference: Perspectives on Justice in the future. St. Paul, MN: West Publishing, 1979, p. 6687 , p. 69.

${ }^{270}$ O termo "processo administrativo" designa uma série de situações que não podem ser confundidas para a finalidade desse trabalho, pois nem todas configuram um meio adjudicatório de solução de controvérsias: 1) O termo pode designar o "contencioso administrativo" que se desenrola perante uma jurisdição administrativa separada da jurisdição comum. Segundo Odete Medauar, na França, originou-se a ideia de evitar a interferência do Judiciário em atos da administração, o que resultou na edição da Lei do 16 fructidor, ano III (1796), que vedava tais interferências, e, na sequência, culminou na criação do Conselho de Estado, então submetido ao Primeiro Cônsul, como sede para solução definitiva de litígios envolvendo a Administração Pública. Em 1872, reconheceu-se a independência funcional do Conselho de Estado, da qual o Judiciário comum já gozava, formando verdadeira jurisdição administrativa com as mesmas garantias do Judiciário. Hoje, entende-se por "contencioso administrativo" "um sistema em que existe uma jurisdição autônoma, independente da Administração e de jurisdição comum, para decidir os litígios referentes à Administração Pública em geral" (MEDAUAR, Odete. A processualidade no direito administrativo. São Paulo: RT, 1993, p. 44-45). Esse sistema, inexistente no Brasil, certamente se enquadra no conceito de meio adjudicatório de solução de conflitos, já que suas decisões são definitivas e dotadas de imperatividade; 2) Pode ainda designar a processualidade administrativa, que é uma forma específica de a Administração se relacionar com particulares ou intermediar relações entre eles. Segundo Odete Medauar, processo administrativo, nessa acepção, "caracteriza-se pela atuação dos interessados, em contraditório, seja ante a própria Administração, seja ante outro sujeito (administrado em geral, licitante, contribuinte, por exemplo), todos, neste caso, confrontando seus direitos ante a administração" (MEDAUAR, Odete. Direito administrativo moderno. 4. ed. São Paulo: RT, 2000, p. 195). Dessa forma, segundo a autora, abrange tanto situações em que particulares estejam em posição de controvérsia entre si e a decisão deve ser tomada pela Administração Pública (como licitações e concursos públicos) quanto aquelas em que se contraponham Administração e particular (como licenças em geral, recursos administrativos e reexame de lançamento). Nessa acepção do termo, o processo administrativo pode ser um meio de solução de controvérsias, e, inclusive, um meio adjudicatório, como no caso de conflito entre consumidor e prestador sujeito à regulação da atividade, em que a Administração atua como terceiro que decide. Contudo, a licitação, o concurso público e o licenciamento não são, a princípio, conflitos na acepção adotada no presente trabalho, por que, por mais que envolvam um problema alocativo de bem escasso, não apresentam, a princípio, contraposição de visões sobre como deve ser resolvido o problema. Assim, nem sempre é possível dizer que o processo administrativo é um meio de solução de controvérsias. Por outro lado, mesmo quando o é, faltam-lhe a definitividade e a imperatividade da decisão.

271 Cf. SALLES, Carlos Alberto de. A arbitragem na solução de controvérsias contratuais da Administração Pública, cit., p. 132-133. A questão também é destacada em MANCUSO, Rodolfo de Camargo. A resolução dos conflitos e a função judicial. São Paulo: Revista dos Tribunais, 2009, p. 300. 
Mesmo dentro das subcategorias de meios adjudicatórios, Frank Sander aponta que há diferentes desenhos para diferentes perfis de conflitos, bastando notar a diferença entre um conflito levado a uma "Small Claims Court" e outro submetido à Suprema Corte ${ }^{272}$.

Fernanda Tartuce identifica os meios adjudicatórios com a heterocomposição, o que também é uma linguagem válida. Segundo a autora, os meios heterocompositivos surgiram estimulados pela gradual redução da permissão da autotutela e, modernamente, são encorajados pelo fato de a autocomposição ser fenômeno eventual, devido à intensa litigiosidade ${ }^{273}$.

\subsubsection{Jurisdição estatal e processo judicial contencioso}

O processo judicial é o mecanismo estatal tradicional de solução de conflitos, conduzido e concluído por órgãos do Poder Judiciário previstos constitucionalmente (em atendimento ao princípio do juiz natural) que opera, sobretudo, pelo critério legal; somente sendo permitida a composição pelo critério da equidade nos casos previstos em lei (art. 127 do Código de Processo Civil), como nos procedimentos de jurisdição voluntária (art. 1.109 do Código de Processo Civil) e nos casos submetidos aos Juizados Especiais Cíveis (art. $6^{\circ}$ da Lei n. 9.099/95) $)^{274}$.

Tradicionalmente, é o único considerado como manifestação da jurisdição. Todavia, como já descrito no capítulo 1, esse conceito vem sendo reformulado para abranger também outras instâncias de solução de conflitos, estatais ou não, de imposição ou de indução de soluções.

É marcado por ser, dentre os meios de composição de conflitos aqui descritos, o único meio impositivo, que independem absolutamente da vontade de todas as partes: a arbitragem e os meios consensuais dependem da concordância de todos os envolvidos para que operem. Já o processo judicial estatal, ainda que inerte e dependente da provocação de um dos interessados (o que é garantia constitucionalmente prevista - art. $5^{\circ} \mathrm{XXXV}$ da $\mathrm{CF}$ ),

272 SANDER, Frank E. A. Varieties of Dispute Processing. LEVIN, Leo A.; WHEELER, Russell R (edit.). The Pound Conference, cit., p. 66-87, p. 69.

273 TARTUCE, Fernanda. Mediação nos conflitos civis, cit., p. 74.

274 “Dentro de um contexto axiológico e teleológico, decisão justa não é aquela que simplesmente subsume a norma jurídica ao caso concreto, resolvendo a lide jurídica dentro dos contornos articulados na peça inaugural. A justiça do julgamento transcende o plano objetivo do sistema nomoempírico prescritivo para adentrar o campo da pacificação social, visto que os conflitos intersubjetivos significam um sintoma patológico nas relações de direito material, pela lesão ou ameça de lesão ao direito subjetivado" (FIGUEIRA JÚNIOR, Juizados especiais estaduais cíveis e criminais. 4. ed. São Paulo: RT, 2005, p. 147). 
é inevitável, pois uma vez provocada a jurisdição estatal e verificadas as condicionantes, o autor terá direito a uma resposta do Judiciário, independentemente da vontade dos demais interessados ${ }^{275}$.

Sua forma de operação, mediante atuação dos juízes estatais, ainda que abarque qualquer "lesão ou ameaça a direito" (o que faz proliferar inúmeras especificidades e procedimentos), pode ser resumida da seguinte forma: sendo a autotutela coibida e excepcionalmente autorizada, a não observação do cumprimento das normas de direito material não pode ser coercitivamente imposta pelo próprio interessado; cabendo, portanto, ao Estado, dizer a norma aplicável e fazer atuá-la no caso concreto, em substituição à atividade primária dos destinatários da norma ${ }^{276}$.

Há duas formas de sua manifestação: a primeira delas, a jurisdição contenciosa, que atua propriamente na composição de conflitos, no sentido adotado nesse trabalho e, portanto, sendo a vertente de nosso maior interesse. Nesse caso, o Estado deve dizer a norma aplicável e fazê-la operar no caso porque houve, em tese, resistência por parte de um dos sujeitos envolvidos ou, ainda, porque o ordenamento exige que somente o Judiciário se pronuncie sobre a regra de direito material e a faça ser acatada ("processo necessário"), como no caso da ação penal.

Há, ainda, o processo judicial de jurisdição voluntária, que não atua propriamente na composição de conflitos, pois os interessados já manifestaram sua vontade anteriormente. A lei apenas confere a essas situações a necessidade de submeter essas manifestações ao Judiciário para que possam ter efeitos propriamente jurídicos. Por isso, diz-se que a jurisdição voluntária é apenas "administração pública de interesses privados" 277. Como já visto, é no campo da jurisdição voluntária que se situam muitas das "ações necessárias".

É inegável a importância do processo judicial no Estado Democrático de Direito, bem como todo o processo histórico que envolve o aprimoramento das garantias processuais e a ampliação das matérias que são submetidas e acolhidas pelo Judiciário.

275 BEDAQUE, José Roberto dos Santos. Breves notas sobre jurisdição e ação. ZUFELATO, Camilo; YARSHELL, Flávio Luiz (org.). 40 anos da teoria geral do processo no Brasil: passado, presente e futuro. São Paulo: Malheiros, 2013, p. 537-561, p. 538.

${ }^{276}$ Cf. BEDAQUE, José Roberto dos Santos. Breves notas sobre jurisdição e ação. ZUFELATO, Camilo; YARSHELL, Flávio Luiz (org.). 40 anos da teoria geral do processo no Brasil, cit., p. 537-561, p. 538 e 542.

${ }^{277}$ Cf. BEDAQUE, José Roberto dos Santos. Breves notas sobre jurisdição e ação. ZUFELATO, Camilo; YARSHELL, Flávio Luiz (org.). 40 anos da teoria geral do processo no Brasil, cit., p. 537-561, p. 538545. 
Também não se nega a importância do desenvolvimento de uma postura judicial ativa na afirmação de direitos sociais e pronunciamento sobre questões de interesse coletivo amplo.

Contudo, a pretensão do Poder Judiciário em abarcar toda e qualquer lesão e ameaça a direito, em um contexto de ampliação do rol de direitos sociais e coletivos e de uma crescente imprecisão normativa para sua composição, gerou uma série de críticas ao processo judicial, que vão desde a sua incapacidade em lidar com um volume crescente de demandas judiciais até a sua inadequação como foro de decisão sobre matérias que caberiam primariamente ao foro político, como a distribuição escassa de recursos, por falta de legitimidade ${ }^{278}$ ou conhecimento técnico para tanto ${ }^{279}$.

Para Rodolfo de Camargo Mancuso, um dos problemas gerados é que o Judiciário, ao ocupar vazios deixados pela ineficiência ou leniência dos demais Poderes, acaba por oferecer álibis às mais diversas omissões normativas e administrativas ${ }^{280}$.

\subsubsection{Processo judicial e administração pública em juízo}

A presença de um ente público em um dos polos do processo judicial ocasiona algumas particularidades, que trataremos aqui com o intuito de tornar o panorama claro na medida suficiente para que se compreendam as alternativas da Administração Pública diante de um conflito: compô-lo judicialmente ou extrajudicialmente.

Antes, contudo, é importante entender por quais motivos a Administração Pública vai a Juízo e como a sua presença molda o processo judicial.

O processo pode apresentar variações a depender da qualidade de seus sujeitos, pois a parte envolvida pode fazer inserir aspectos de direito material próprios. Especialmente nos processos envolvendo a Administração Pública, o direito material é muito distinto daquele discutido nas lides de direito privado, e se o processo civil for construído com base nele, é de se questionar se generalizadamente adequado às lides de Direito Público ${ }^{281}$.

Carlos Alberto de Salles sustenta a tese de que o processo civil precisa ser estudado a partir das suas diferentes áreas de aplicação, atentando às particularidades do direito material (e não apenas jurídicas, mas também do contexto social) para que,

${ }^{278}$ Cf. WANG, Daniel Wei Liang. Poder Judiciário e participação democrática nas políticas de saúde. Dissertação (mestrado), São Paulo, Faculdade de Direito da Universidade de São Paulo, 2009, p. 15.

${ }^{279}$ Cf., WANG, Daniel Wei Liang. Poder Judiciário e participação democrática nas políticas de saúde., cit., p. 11.

${ }^{280}$ MANCUSO, Rodolfo de Camargo. A resolução dos conflitos e a função judicial, cit., p. 89.

${ }^{281}$ SUNDFELD, Carlos Ari. O Direito Processual e o Direito Administrativo. SUNDFELD, Carlos Ari; BUENO, Cassio Scarpinella. Direito Processual Público, cit., p. 16. 
independentemente de previsão legal de ritos especiais e instrumentos processuais específicos, esteja o julgador do processo (que também é seu dirigente) apto a conduzi-lo da forma mais adequada ao direito material. Essa tese sustenta também uma mudança na metodologia do estudo do processo, em que os seus instrumentos fossem pensados a partir do direito material e das particularidades sociais envolvidas ${ }^{282}$.

Carlos Ari Sundfeld realça a necessidade de consciência da existência do ramo do Direito Processual Público, que é, no fundo, a parte "que regula os processos judiciais que tenham ou como objeto o Direito Público ou como parte a Administração Pública", bem como "em que o Direito Público é o direito material envolvido, donde a redução do campo temático pela aposição do termo 'Público', de modo a estabelecer uma distinção em relação ao Direito Processual propriamente Civil" ${ }^{283}$.

Enquanto ocupante de posição ativa no processo judicial, a Administração Pública dele se socorre quando não pode realizar o interesse público por atos administrativos autoexecutórios, dependendo do acesso ao Poder Judiciário, uma "busca complexa do interesse público, em que a Administração não pode invadir a esfera de direitos do administrado por ato próprio, o que se evidencia, normalmente, quando o direito à liberdade ou o direito à propriedade estão envolvidos, vide a ação penal e as ações de execução" 284

A Administração, em juízo, dispõe de ações especiais construídas para a realização de interesse público específico, como o são as execuções fiscais. Fora a necessidade prática em si, há nelas uma função simbólica. O autor aponta que o grau de ineficácia da execução fiscal é alto, mas a sua simples existência garante a eficácia global do sistema tributário ${ }^{285}$.

A ação de desapropriação é outro exemplo de como o processo se adaptou às necessidades da Administração Pública, pois surgida da negação que a Constituição dava à Administração Pública de privar o particular de sua propriedade por ato autoexecutório. Assim, como forma de equilíbrio e devido processo legal, foi conferido ao Judiciário o controle dessa expropriação. Cabe, então, ao Judiciário verificar a existência ou não do

${ }^{282}$ SALLES, Carlos Alberto de. A arbitragem na solução de controvérsias contratuais da Administração Pública, cit., p. 45-48.

${ }^{283}$ SUNDFELD, Carlos Ari. O Direito Processual e o Direito Administrativo. SUNDFELD, Carlos Ari; BUENO, Cassio Scarpinella. Direito Processual Público, cit., p. 18.

${ }^{284}$ SUNDFELD, Carlos Ari. O Direito Processual e o Direito Administrativo. SUNDFELD, Carlos Ari; BUENO, Cassio Scarpinella. Direito Processual Público, cit., p. 18.

${ }^{285}$ SUNDFELD, Carlos Ari. O Direito Processual e o Direito Administrativo. SUNDFELD, Carlos Ari; BUENO, Cassio Scarpinella. Direito Processual Público, cit., p. 19. 
interesse público, fixar a indenização e exigi-la como condição para que o bem se torne propriedade pública.

Contudo, a necessidade de atendimento imediato do interesse público fez surgir a solução da imissão provisória na posse, que comprometeu muito, na visão de Sundfeld, a eficácia do regime da ação expropriatória do ponto de vista da garantia do particular. A imissão provisória é uma inversão da ação de desapropriação, pois nesta o pagamento da indenização é condição da obtenção da propriedade. Na prática, não existem ações de desapropriação que terminem na forma inicialmente concebida, pois a imissão prévia na posse transformou-se em regra. Assim, o interesse no pagamento deixa de ser da autora, Administração Pública, e passa a ser inteira e exclusivamente do réu ${ }^{286}$.

O autor dá esse exemplo para demonstrar como o direito material (e acrescente-se, as dificuldades do contexto social em que ele se insere) molda o direito processual, pois a necessidade da Administração Pública em imitir-se rapidamente na posse inverteu a lógica da ação de desapropriação ${ }^{287}$.

Quando tomamos a Administração como ré, a discussão que aflora é da legitimidade da interferência judicial na ação administrativa, o modo em que ela vai se realizar e seus limites. Dois opostos orientam a discussão: se, por um lado, o Judiciário aparece como controlador da legalidade e pode inibir uma administração ilegal e ditatorial, por outro lado, o Judiciário não é um órgão democraticamente eleito e sua interferência deve ser limitada pela democracia, presente no Legislativo seguido pelo Executivo ${ }^{288}$.

A partir desse ponto emergem as questões sobre a profundidade e a abrangência dos instrumentos legais para controle judicial da Administração, de sua velocidade ou, ainda, para realizar juízos provisórios (como a concessão de liminares): “em que medida o juízo provisório de um magistrado totalmente alheio à solução de um dado problema social é mais legítimo do que o juízo provisório formulado por um órgão administrativo que, por dever de ofício, está envolvido com o assunto permanentemente?", 289

As limitações do processo judicial para lidar com a Administração Pública em juízo se evidenciam mais quando temos em vista que, no atual perfil do Estado Social de Direito,

\footnotetext{
286 SUNDFELD, Carlos Ari. O Direito Processual e o Direito Administrativo. SUNDFELD, Carlos Ari; BUENO, Cassio Scarpinella. Direito Processual Público, cit., p. 20-21.

${ }^{287}$ SUNDFELD, Carlos Ari. O Direito Processual e o Direito Administrativo. SUNDFELD, Carlos Ari; BUENO, Cassio Scarpinella. Direito Processual Público, cit., p. 20-21.

${ }^{288}$ SUNDFELD, Carlos Ari. O Direito Processual e o Direito Administrativo. SUNDFELD, Carlos Ari; BUENO, Cassio Scarpinella. Direito Processual Público, cit., p. 25-26.

${ }^{289}$ SUNDFELD, Carlos Ari. O Direito Processual e o Direito Administrativo. SUNDFELD, Carlos Ari; BUENO, Cassio Scarpinella. Direito Processual Público, cit., p. 26.
} 
em que surgem muitas demandas ligadas a liberdades positivas (direitos de prestação), ao Judiciário são colocadas questões que vão muito além do controle de legalidade e da subsunção do fato à norma (crises jurídicas), e que envolvem questões de ordem econômica, política e social, demandando escolhas valorativas, conflitos alocativos que não são dirimidos por critério legal claro.

Esse fenômeno é denominado, por Rodolfo de Camargo Mancuso, como “judicialização da política” ou "politização do Judiciário". Dentre essas demandas, encontram-se aquelas que envolvem opções de caráter político ou escolhas primárias, normalmente atribuídas à Administração, como, em um exemplo hipotético, a questão relativa à supressão de vegetação para formação de uma represa para fomento de uma hidrelétrica. Nesses casos, cabe ao Judiciário a ponderação entre princípios envolvidos, mediante a operação do binômio razoabilidade-proporcionalidade ${ }^{290}$.

$\mathrm{O}$ autor adverte que a ampliação dos horizontes para além de crises estritamente jurídicas traz pontos de tensão entre o Judiciário e os demais Poderes, especialmente a Administração, dos seguintes tipos:

(i) uma propensão ao não-enfrentamento do mérito, nos conflitos metaindividuais, mormente aqueles derivados de omissão ou ineficiência da Administração Pública, por conta da falta ou oferta insuficiente das prestações devidas à coletividade (...); (ii) resistência ao cumprimento de ordens judiciais socialmente impactantes ( $v . g$. protelação ou não-cumprimento dos mandados de reintegração de posse nos megaconflitos fundiários) ou onerosas ao erário (atraso no pagamento de precatórios (... $)^{291}$.

Outro tema suscitado para entender a relação entre processo judicial e Administração Pública é a interferência do primeiro nos atos discricionários da segunda. De fato, a evolução da interferência judicial na Administração Pública acompanha pari passu a evolução do entendimento sobre a discricionariedade administrativa, como fica claro em exposição sintética feita por Maria Sylvia Zanella de Pietro.

A autora nos relata algumas fases do fenômeno: na primeira delas, na égide do Estado de Polícia, a discricionariedade era compreendida como um poder político, sem qualquer limitação. Quanto ao controle judicial, era uma fase de imunidade jurisdicional que, segundo a autora, mantém alguns resquícios ainda hoje quando se afirma que "atos políticos não são passíveis de apreciação judicial"292.

\footnotetext{
${ }^{290}$ MANCUSO, Rodolfo de Camargo. A resolução dos conflitos e a função judicial, cit., p. 362-363.

${ }^{291}$ MANCUSO, Rodolfo de Camargo. A resolução dos conflitos e a função judicial, cit., p. 369-370.

292 DI PIETRO, Maria Sylvia Zanella. Discricionariedade administrativa e controle judicial da administração. SALLES, Carlos Alberto de (org.). Processo civil e interesse público, cit., p. 181-190, p. 194-195.
} 
Na segunda fase, correspondente ao Estado de Direito liberal, a discricionariedade passou a sofrer alguma limitação, com o princípio da legalidade incidindo, ainda que de forma restrita, de modo a abranger apenas aspectos de interferência em direitos individuais. Adotava-se o princípio da vinculação negativa ("é dado à Administração fazer tudo o que não é proibido pela lei”). O controle judicial nessa fase era muito simples, limitando-se a vícios de forma e competência ${ }^{293}$.

A evolução da discrionariedade passa, sob influência do positivismo jurídico, para um período em que a vinculação negativa é substituída pela vinculação positiva, sendo dado à Administração fazer apenas o que a lei permite. Um passo seguinte veio com o Estado Democrático de Direito, em que a vinculação da Administração à lei deixou de ser a mera vinculação formal e passa a compor uma vinculação axiológica, que reflete valores e princípios constantes no ordenamento jurídico ${ }^{294}$.

O avanço no controle da discricionariedade se deu com a elaboração das teorias do desvio de poder e dos motivos determinantes: a finalidade e o motivo passaram a ser considerados elementos do ato administrativo passíveis de controle pelo Judiciário. Essas teorias, segundo a autora, abriram espaço para a apreciação da materialidade fática que envolvia o Judiciário e, especialmente, da adequação dos fatos aos fins, de maneira a verificar, por exemplo, se a Administração escolheu o meio mais adequado, se agiu de forma excessiva, etc ${ }^{295}$.

Para a autora, atualmente também justifica a ampliação do controle da discricionariedade administrativa a teoria dos conceitos indeterminados, criticando a postura de juízes que se furtam da apreciação de atos discricionários sob o fundamento da impossibilidade de adentrar no "mérito administrativo". Defende, assim, que , se a lei usa um conceito jurídico indeterminado, escolhido pelo legislador eleito democraticamente, tem-se que aceitá-lo como um balizador da discricionariedade administrativa sujeito a controle pelo Judiciário.

Outro fundamento que a autora utiliza para justificar o controle judicial da discricionariedade é a pluralidade de "interesses públicos" na sociedade, cujo arbitramento não pode ser relegado apenas à Administração, visto que se reconhece a diversos grupos a

\footnotetext{
${ }^{293}$ DI PIETRO, Maria Sylvia Zanella. Discricionariedade administrativa e controle judicial da administração. SALLES, Carlos Alberto de (org.). Processo civil e interesse público, cit., p. 181-190, p. 194-195.

${ }^{294}$ DI PIETRO, Maria Sylvia Zanella. Discricionariedade administrativa e controle judicial da administração. SALLES, Carlos Alberto de (org.). Processo civil e interesse público, cit., p. 181-190, p. 194-195.

${ }^{295}$ DI PIETRO, Maria Sylvia Zanella. Discricionariedade administrativa e controle judicial da administração. SALLES, Carlos Alberto de (org.). Processo civil e interesse público, cit., p. 181-190, p. 194-195.
} 
sua titularidade. E se há conflito entre interesses públicos diversos, o Judiciário é que decide em última instância sobre os conflitos ${ }^{296}$.

Prosseguindo no raciocínio da autora, Floriano Marques Azevedo, também com base na pluralidade de "interesses públicos" e na necessidade de a Administração Pública arbitrá-los, propõe o alargamento do controle judicial da discricionariedade como forma, inclusive, de se evitar que, nesse movimento de arbitramento, interesses particularísticos prevaleçam sobre interesses da coletividade. Portanto, se cada vez menos a lei prevê os limites da ação administrativa, cada vez mais é necessário ampliar o controle jurisdicional sobre a discricionariedade.

Isso demandaria, ainda na visão do autor, que os atos discricionários fossem sempre acompanhados de profunda e comprida motivação e fundamentação pela autoridade, com as razões pelas quais adotou um juízo discricionário e não outro, e contemplando, em primeiro plano, alguns interesses e não outros ${ }^{297}$. O autor não hesita em afirmar que “também é imprescindível que esse controle seja feito pelo Judiciário, com físcalização de órgãos como o Ministério Público. Portanto, cresce a margem de controle judicial da discricionariedade" ${ }^{298}$.

Dessas linhas podemos inferir que, se por um lado a judicialização excessiva de demandas com a Administração Pública, no polo ativo ou passivo, causa problemas de legitimidade e de efetividade prática da ingerência em políticas públicas, por outro lado o aumento da discricionariedade da Administração, com a atribuição de função de arbitradora de interesses, demanda maior intervenção judicial para controle dos atos administrativos e garantia do cumprimento de finalidades ligadas à coletividade.

Sem pretender esgotar ou solucionar o aparente impasse, o fato é que esse panorama da relação entre Administração Pública e processo judicial posiciona muitas dificuldades e abre margem para a discussão de outros mecanismos de solução de conflitos que a promovam adequadamente.

\subsubsection{Arbitragem}

\footnotetext{
${ }^{296}$ DI PIETRO, Maria Sylvia Zanella. Discricionariedade administrativa e controle judicial da administração. SALLES, Carlos Alberto de (org.). Processo civil e interesse público, cit., p .181-190, p. 194-195.

${ }^{297}$ MARQUES, Floriano Azevedo. Discricionariedade administrativa e controle judicial da administração. SALLES, Carlos Alberto de (org.). Processo civil e interesse público, cit., p. 191-198, p. 194-195.

${ }^{298}$ MARQUES, Floriano Azevedo. Discricionariedade administrativa e controle judicial da administração. SALLES, Carlos Alberto de (org.). Processo civil e interesse público, cit., p. 191-198, p. 195.
} 
A arbitragem é "meio alternativo de solução de controvérsias através da intervenção de uma ou mais pessoas que recebem seus poderes de uma convenção privada, decidindo com base nela, sem intervenção estatal, e sendo a decisão destinada a assumir a mesma eficácia da sentença judicial" ${ }^{299}$.

É típico meio adjudicatório, pois o conflito é composto por terceiros de forma impositiva. É tido como um órgão dotado de jurisdição, no sentido atualizado já adotado no presente trabalho (vide item 1.3.3.1), pois além de compor justamente um conflito (o que é um critério adotado para o sentido mais abrangente possível de "jurisdição"), a decisão proveniente da arbitragem tem caráter definitivo (imperativo), e o árbitro possui o poder de decidir e executa atividade muito próxima a do juiz, ao contrário de outras instâncias de decisão "adjudicatória", como órgãos administrativos, cujas decisões estão sempre sujeitas a revisão judicial, e de meios consensuais, em que falta o elemento da imposição de decisões.

Falta-lhe, contudo, a coercitividade, pois uma vez proferida a decisão, esta ganha qualidade de título executivo judicial (art. 475-N, IV, do CPC) e deve ser executada perante a Justiça estatal. Carece o árbitro do poder de forçar a ocorrência dos efeitos do laudo arbitral que demandem ingerência em patrimônio e, também, do poder de tomar medidas coercitivas e cautelares (art. $22, \S^{\circ}$, da Lei n. 9.307/96).

Há variações dessa explicação com o objetivo de equacionar o dissenso em torno do conceito de "jurisdição" e da possibilidade de ele abranger ou não a arbitragem: Rodolfo de Camargo Mancuso coloca-a como uma "instância parajurisdicional, subjacente ou justaposta à função judicial do Estado, interagindo com esta, mas com ela não se confundindo nem imbricando" 300 .

Ademais, a arbitragem é efetivo equivalente jurisdicional e, mais que isso, um substitutivo ao processo judicial, pois se as partes escolhem submeter uma controvérsia a arbitragem, por meio de convenção de arbitragem ou de cláusula compromissória, exclui a possibilidade de submetê-la ao juízo estatal, como fica claro a partir da leitura do art. 267, VII, do CPC.

A arbitragem, por ser meio adjudicatório e não consensual, não é objeto do presente trabalho. No entanto, para o desenvolvimento do tema "meios consensuais $\mathrm{e}$ Administração Pública", a literatura desenvolvida sobre "arbitragem e Administração Pública" é extremamente útil ao tema, por ter gerado, ainda nos anos seguintes à edição da

${ }^{299}$ CARMONA, Carlos Alberto. Arbitragem e processo. 2. ed. São Paulo: Atlas, 2006, p . 51.

${ }^{300}$ MANCUSO, Rodolfo de Camargo. A resolução dos conflitos e a função judicial, cit., p. 265. 
Lei n. 9.307, duas discussões essenciais: (i) a necessidade ou não de autorização legal para a Administração Pública adotar outros meios de solução de conflitos que não o processo judicial; (ii) a delimitação do conceito de "indisponibilidade", posto que a arbitrabilidade objetiva cinge-se, segundo a Lei de Arbitragem, a "litígios relativos a direitos patrimoniais disponíveis" $\left(\operatorname{art} 1^{\circ}\right)$.

Por tal motivo, referências à arbitragem serão feitas no próximo capítulo a fim de estabelecer, por aproximação mais dos instrumentos de pesquisa do que conceitual, os limites da adoção de meios consensuais pela Administração Pública.

\subsection{Meios consensuais de solução de conflitos}

Os meios consensuais integram os meios autocompositivos, para utilizar linguagem mais tradicional, em que "os próprios sujeitos envolvidos no conflito, ou um deles unilateralmente, encontram caminho apto à pacificação" ${ }^{301}$. São meios autocompositivos bilaterais ou multilaterais, pois necessitam da participação e do encontro das vontades de todos os envolvidos, ao contrário dos unilaterais, que são métodos cuja solução do conflito se faz a partir da vontade de um só participante, independentemente da manifestação de vontade do outro.

Estritamente do ponto de vista do processo civil, costuma-se dizer que a autocomposição unilateral pode resultar em: (i) renúncia por quem vinha externando alguma pretensão, o que acarreta a extinção tanto do processo quanto do próprio direito supostamente existente, e pode ocorrer tanto na fase de conhecimento (art. 269, do CPC) quanto na fase de execução (art. 794, III, do CPC); (ii) alguém que vinha resistindo a uma pretensão se submete a ela, reconhecendo o pedido veiculado no processo, acarretando extinção do processo e reconhecimento do pedido (art. 269, V e art. 794, III, ambos do CPC $)^{302}$. Diz-se, ainda, que a autotutela, absoluta exceção em nosso ordenamento, é forma de autocomposição unilateral.

Já a autocomposição bilateral ou multilateral, ainda do ponto de vista dos efeitos no processo civil, é identificada com a figura da transação (art. 840 do Código Civil), e pode ser espontânea (diretamente entre as partes, por meio de negociação) ou induzida, onde as

301 DINAMARCO, Cândido Rangel. Instituições de direito processual civil. 7. ed. São Paulo: Malheiros, 2013, v. I, p. 122.

${ }^{302}$ DINAMARCO, Cândido Rangel. Instituições de direito processual civil, cit., p. 122. 
partes contam com a intercessão de uma terceira pessoa, o mediador ou o conciliador (mediação e conciliação) $^{303}$. São, de fato, as formas autocomposição bilateral ou multilateral que nos interessam no presente trabalho.

Ainda vendo sob a ótica do processo civil, os resultados da conciliação ou mediação poderiam ser resumidos da seguinte forma: se extraprocessual, podem levar à submissão, à renúncia ou à transação que, posteriormente, pode ser ou não homologada em juízo ou referendada pelo Ministério Público ou Defensoria Pública para que se torne título executivo judicial (art. 475-N, inciso III, do Código de Processo Civil); se endoprocessual, pode resultar, além dos resultados listados no âmbito extraprocessual, na desistência da ação $^{304}$.

O problema em analisar a autocomposição do ponto de vista de seus resultados no processo judicial contencioso é conceber a autocomposição a partir da posição que as partes adotam ou adotariam em um processo judicial, de forma que os resultados da autocomposição são sempre vistos como uma maneira de "abrir mão" de algo. Isso fica claro ainda em definições de autores recentes sobre autocomposição: “é a forma de solução do conflito pelo consentimento espontâneo de um dos contendores em sacrificar $o$ interesse próprio, no todo ou em parte, em favor do interesse alheio. É a solução altruísta do litígio", diz Fredie Didier Jr. ${ }^{305}$.

Essa visão revela uma lógica adversarial e posicional. A autocomposição pode, de fato, resultar num ato de renúncia (de um interesse, de todo o direito tutelado juridicamente, de parte dele, da posição adotada processualmente, da defesa, etc.), como acontece em grande parte das vezes. Contudo, essa suposição não comporta o integral potencial dos meios consensuais e, portanto, essa "renúncia" não pode fazer parte da definição. Tal concepção dificulta, de certa maneira, o reconhecimento pela Administração Pública da utilização de autênticas vias consensuais, por pressupor que se estará abrindo mão de parte do bem ou interesse público. Trataremos melhor dessa questão ao contrapor a transação com o potencial dos meios consensuais.

Por tais motivos, adotamos aqui um conceito de meios consensuais pela estrutura de construção da composição, em que as partes chegam ao resultado por elas mesmas, e que depende apenas do encontro de suas vontades, qualquer que seja o resultado. Em outra oportunidade, definimos "solução consensual" ou "solução negociada" como

\footnotetext{
${ }^{303}$ DINAMARCO, Cândido Rangel. Instituições de direito processual civil, cit., p. 124-125.

${ }^{304}$ DINAMARCO, Cândido Rangel. Instituições de direito processual civil, cit., p. 127.

${ }^{305}$ DIDIER JR., Fredie. Curso de direito processual civil. 14. ed., Salvador: JusPodivm, 2012, v. 1, p. 105.
} 
tanto a [solução] que é atingida pela negociação direta entre as partes quanto aquela facilitada por um terceiro imparcial valendo-se da conciliação (instituto mais ligado à obtenção de uma "solução") ou da mediação (instituto vinculado primariamente ao restabelecimento da comunicação eficiente entre os envolvidos, que pode incidentalmente culminar na "solução" do conflito por um acordo) $)^{306}$.

Costuma-se diferenciar os meios consensuais dos meios adjudicatórios pela sua capacidade de tratar questões que ficariam de fora de um recorte exclusivamente jurídicoprocessual. Estar-se-ia tratando da litigiosidade remanescente, que persistiria entre as partes após o tratamento adjudicatório, seja por envolver matéria que não é juridicamente tutelada, seja pelo escopo do processo adjudicatório não ter abrangido todas as questões jurídicas que circundam o conflito ${ }^{307}$.

Na sequência, trataremos os meios consensuais nas três espécies de interesse.

\subsubsection{Negociação direta}

A negociação pode ser entendida como a comunicação estabelecida diretamente entre as partes para buscar um acordo ${ }^{308}$. Em certo sentido, a negociação é o processo de comunicação em que duas ou mais pessoas decidem sobre a distribuição de valores escassos $^{309}$; em outras palavras, negocia-se para obter com o outro aquilo que sozinho não seria obtido. Pode-se acrescentar a essa definição que as partes pretendem, via comunicação, influenciar-se reciprocamente para atingirem determinado resultado.

A negociação é trivial, e manifesta-se nas situações mais comezinhas ${ }^{310}$. O que se percebe analisando o ato de negociar é que ele sempre visa o atingimento de um interesse (qualquer que seja sua natureza) que pode ser alcançado com a colaboração do outro ${ }^{311}$.

306 TARTUCE, Fernanda; BERGAMASCHI, André Luís. A solução negociada e a figura jurídica da transação: associação necessária? SIMÃO FILHO, Adalberto; MEDEIROS NETO, Elias Marques de; FIGUEIRA, Janahim Dias (coor.). Direito dos negócios aplicado, v. II - do direito processual (no prelo).

307 AZEVEDO, André Gomma de. Novos desafios do acesso à justiça: novas perspectivas decorrentes de novos processos de resolução de disputas. SILVA, Luciana Aboim Machado Gonçalves da (org.). Mediação de conflitos. São Paulo: Atlas, 2013, p. 9.

308 TARTUCE, Fernanda; FALECK, Diego; Gabbay, Daniela. Meios alternativos de solução de conflitos. Rio de Janeiro: FGV, 2014, p. 19.

${ }^{309}$ MOURÃO, Alessandra Nascimento S. F. et al. Resolução de conflitos: Fundamentos da Negociação para o ambiente jurídico. São Paulo: Saraiva (Série GVlaw), 2014, p. 24.

310 Já tivemos a oportunidade de melhor esclarecer as manifestações triviais da negociação: “A negociação é trivial e se expande para as mais diversas situações de escassez: colegas de trabalho, por exemplo, negociam sobre o horário de uma reunião ou a posição das escrivaninhas, assim como filhos negociam com os pais quando poderão utilizar o tablet para jogos de diversão. A negociação pode também ter contornos afetivos quando, por exemplo, namorados negociam sobre o uso do celular no tempo livre que passam juntos. Ela também pode focar o âmbito dos interesses econômicos: vendedor e comprador negociam porque um deseja 
Por outro lado, a negociação pode ser situada como um meio de solução de conflitos, que interessa às políticas de justiça, quando ela recai sobre uma situação de insatisfação $^{312}$ ou, ainda mais adequadamente ao conceito de conflito adotado neste trabalho, em situações em que haja contraposição de condutas e diferentes percepções sobre como resolver o problema alocativo.

A negociação é tida como o mais fluido, básico e elementar meio de se resolver controvérsias, sendo também o meio menos custoso porque os envolvidos, por si mesmos, resolvem a disputa sem a ajuda de terceiros (e sem, portanto, os gastos decorrentes da inclusão de outras pessoas) ${ }^{313}$.

Discussão importante que emerge no tema da negociação é a respeito das bases em que a negociação é travada.

A insistência em critérios objetivos para as negociações ${ }^{314}$ para ponderação das opções de composição criadas é uma das recomendações da "negociação baseada em princípios" (método de Harvard), em vez de negociar com base apenas na vontade, característica típica da barganha posicional, método ineficiente e que não atende a critérios justos. Por outro lado, é mais fácil negociar com alguém se baseando em critérios objetivos, discutindo sua validade e sua aplicação ao caso. Tal conduta cria resultados mais sensatos do que se basear unicamente na vontade.

A negociação em torno dos conflitos de justiça envolvendo a Administração Pública naturalmente deve se dar com base em critérios objetivos e, mais especificamente, em critérios legais. Contudo, como veremos mais à frente, o fato de a Administração estar

o objeto que pertence ao outro, enquanto o outro deseja obter dinheiro se desfazendo do mesmo objeto. No mesmo sentido, dois empresários negociam os termos de uma joint venture para a realização de um projeto que demanda a expertise de ambos. O que se percebe analisando o ato de negociar é que ele sempre visa o atingimento de um interesse (qualquer que seja sua natureza) que pode ser alcançado com a colaboração do outro. A negociação pode ocorrer em contextos litigiosos ou não - o que não quer dizer que não haja um ambiente em que percepções, posições e interesses estejam em conflito. Independentemente da percepção do outro como opositor ou adversário, há sempre questões a se responder e opções a fazer. Mesmo para a tomada de decisão sobre onde almoçar com a família no domingo, certamente haverá pontos a serem definidos - ainda que nenhum dos envolvidos assuma a postura de adversário dos demais. Existem até mesmo conflitos que têm como pretexto a distribuição de valores escassos, mas que, no fundo, são apenas impasses aparentes ocasionados por falhas de comunicação ou questões emocionais" (TARTUCE, Fernanda; BERGAMASCHI, André Luís. A solução negociada e a figura jurídica da transação: associação necessária? SIMÃO FILHO, Adalberto; MEDEIROS NETO, Elias Marques de; FIGUEIRA, Janahim Dias (coor.). Direito dos negócios aplicado, cit., no prelo).

311 TARTUCE, Fernanda; BERGAMASCHI, André Luís. A solução negociada e a figura jurídica da transação: associação necessária? SIMÃO FILHO, Adalberto; MEDEIROS NETO, Elias Marques de; FIGUEIRA, Janahim Dias (coor.). Direito dos negócios aplicado, cit. (no prelo).

${ }^{312}$ Cf. TARTUCE, Fernanda. Mediação nos conflitos civis, cit., p. 23-29.

313 TARTUCE, Fernanda; FALECK, Diego; Gabbay, Daniela. Meios alternativos de solução de conflitos, cit., p 19.

${ }^{314}$ FISHER, Roger; URY, William; PATTON, Bruce. Getting to Yes, cit., p. 82-95. 
adstrita à legalidade não significa a impossibilidade de, consensualmente, construir sentidos possíveis para as normas, sobretudo quando estão em jogo conceitos indeterminados e princípios.

Como algo que depende exclusivamente das partes pode ser fomentado em uma política de tratamento de conflitos? Uma possível resposta é que atores institucionais (como é o caso da Administração Pública direta nos diferentes níveis federativos, seus órgãos e entes da administração pública indireta) e grandes litigantes internos podem instituir e estimular canais internos de acesso dos indivíduos para que possam negociar suas controvérsias. Exemplos dessa prática existem, como ficará demonstrado na pesquisa empírica realizada, e devem ser fomentados, se adequados para os conflitos em questão.

\subsubsection{Conciliação e mediação}

A conciliação e a mediação se diferenciam da negociação direta pela intervenção de um terceiro facilitador da comunicação. São práticas muito próximas e de controversa diferenciação. Nos próximos tópicos, primeiro se tratará se é justificável uma diferenciação entre as duas figuras. Na sequência, trataremos de breves notas características de cada um deles e, por último, tentaremos esclarecer melhor a relação entre esses meios consensuais e a "transação", figura contratual prevista no art. 840 do Código Civil.

\subsubsection{Mediação e conciliação: diferenças?}

Importante mencionar que, até pouco tempo, não existia um conceito normativo de “mediação" ou "conciliação". O debate se travava entre os práticos dos meios consensuais de conflito muito mais do que no plano teórico-dogmático. Não obstante, a discussão tem potencial para repercutir na dogmática jurídica haja vista a iminência de um novo Código de Processo Civil (PLS 166/2010, aprovado em 17.12.2014), além do Projeto de Lei da Câmara n. 7169/2014, do qual trataremos mais adiante, ambos trazendo elementos de diferenciação.

No movimento norte-americano das ADRs (Alternative Dispute Resolutions), não existe essa distinção. O que aqui chamamos de "conciliação" também está sob a denominação de mediation, termo que designa práticas de intermediação de conflitos, 
independentemente da atuação mais propositiva e até avaliativa ou não do terceiro imparcial, já tendo sido destacado que há diferentes modalidades a serem utilizadas de acordo com o perfil concreto do conflito.

Muitos entendem a distinção como algo artificial, levando em consideração a ausência da distinção na literatura norte-americana e o fato de que as técnicas são utilizadas conforme as necessidades concretas do caso e não dadas a priori segundo um rótulo nominal. Para Luciane Moessa de Souza, por exemplo, o mais relevante é a abordagem, mais rasa ou mais aprofundada, do conflito e de suas razões: enquanto no que se denomina conciliação essa abordagem é mais superficial, a ideia na mediação é de aprofundar a análise, pois seu objetivo é preservar o relacionamento, valorizando o aspecto pedagógico ${ }^{315}$.

Na Itália, de onde herdamos a denominação conciliazione, foi aprovado o DecretoLegislativo n. 28, de 04.03.2010 ${ }^{316}$, que define os termos da seguinte forma:

Art. 1

1. Ai fini del presente decreto legislativo, si intende per:

a) mediazione: l'attività, comunque denominata, svolta da un terzo imparziale e finalizzata ad assistere due o più soggetti sia nella ricerca di un accordo amichevole per la composizione di una controversia, sia nella formulazione di una proposta per la risoluzione della stessa;

b) mediatore: la persona o le persone fisiche che, individualmente o collegialmente, svolgono la mediazione rimanendo prive, in ogni caso, del potere di rendere giudizi o decisioni vincolanti per i destinatari del servizio medesimo;

c) conciliazione: la composizione di una controversia a seguito dello svolgimento della mediazione;

Art. 2.

1. Chiunque può accedere alla mediazione per la conciliazione di uma controversia civile e commerciale vertente su diritto disponibili, seconde le disposizioni del presente decreto (grifos nossos).

Nota-se que, pela lei italiana, a conciliação se confunde com a composição do conflito, e é apenas o fruto do processo de mediação. Não há, portanto, uma dicotomia de procedimentos.

Contudo, a prática brasileira atual nos revela duas linhas bem distintas de atuação e de um consenso mais ou menos difundido: a uma, a conciliação, normalmente ligada ao Judiciário e que promove a solução de um ou mais problemas objetivos, em que o terceiro

315 SOUZA, Luciane Moessa de. Resolução consensual de conflitos envolvendo o Poder Público: caminho possível e adequado, com o devido respeito às peculiaridades do regime jurídico-administrativo. Revista do Advogado. São Paulo, AASP, n. 123, ago.2014, p. 162-169, p. 167-168, nota de rodapé n. 6.

${ }^{316}$ Disponível em: < http://www.camera.it/parlam/leggi/deleghe/10028dl.htm>. Acesso em: 01/08/2014. 
busca zonas de convergência para um possível acordo (ou ao menos deveria) e, a duas, a mediação, voltada especificamente mais ao restabelecimento da comunicação e o tratamento de conflitos intersubjetivos com uma carga maior de questões pessoais.

Isso se revela não apenas na linguagem corrente, mas também o ensino dos meios consensuais $^{317}$ vem assim sendo moldado, por seus aspectos práticos e, paralelamente, na forma como atores institucionais importantes - entre eles, o Judiciário - vêm apresentando o tema.

Por exemplo, na redação original da Resolução n. 125/2010 do CNJ, antes das alterações feitas pela Emenda n. 1, de 31.01.2013, subentendia-se a adoção de uma distinção entre conciliação e mediação. Isso porque no Anexo I (Cursos de Capacitação e Aperfeiçoamento), a formação de conciliadores e mediadores é feita de forma diversa. Exige-se de conciliadores e mediadores o curso do Módulo II ("Conciliação e suas técnicas"). Já dos mediadores, e apenas deles, era exigido cursar, além do módulo de conciliação, um módulo extra (Módulo III - "Mediação e suas técnicas"), em cujo programa se contemplam etapas próprias (planejamento da sessão, apresentação ou abertura, esclarecimentos ou investigação das propostas das partes, criação de opções, escolha da opção) e técnicas não contempladas no programa de conciliação (co-mediação). Havia uma pressuposição de que a mediação seria um processo mais complexo e cuidadoso do que a conciliação.

A Emenda n. 1 alterou a Redação do Anexo I, e remeteu o conteúdo dos cursos de capacitação às publicações no Portal da Conciliação do $\mathrm{CNJ}^{318}$. No entanto, tal Portal transparece o espírito da diferenciação. Consta no site que

A Conciliação tem como sua principal missão a realização do acordo, evitando, assim, a continuidade do conflito. E pode ser utilizada em quase todos os casos: pensão alimentícia, divórcio, desapropriação, inventário, partilha, guarda de menores, acidentes de trânsito, dívidas em bancos e financeiras e problemas de condomínios.

Já a mediação, no entendimento do CNJ, seria

uma forma de solução de conflitos por meio de uma terceira pessoa (facilitador) que não está envolvida com o problema. A proposta é que o facilitador favoreça o diálogo entre

\footnotetext{
317 Alessandra Mourão et al., ao relatar a presença das ADRs no ensino jurídico no Brasil, relatam a existência dessa diferença nas grades curriculares: MOURÃO, Alessandra Nascimento S. F. et al. Resolução de conflitos: Fundamentos da Negociação para o ambiente jurídico. São Paulo: Saraiva (Série GVlaw), 2014, p. 28.

${ }^{318}$ Disponível em: <http://www.cnj.jus.br/programas-de-a-a-z/acesso-a-justica/conciliacao>
} 
as partes, para que elas mesmas construam, com autonomia e solidariedade, a melhor solução para o problema.

A Mediação pode ser mais demorada e até não terminar em acordo, como sempre acontece na Conciliação. Mas, mesmo assim, as partes têm considerado a Mediação bastante positiva, pois, ao final dos debates, os envolvidos estão mais conscientes e fortalecidos.

Nota-se que, na visão do órgão de controle do Judiciário, oqual sem dúvida influencia a cultura judiciária, a conciliação realmente se presta a encerrar processos judiciais mediante a realização de um acordo, não parecendo ser escopo igualmente importante, tal como posto, o restabelecimento do diálogo ou tratamento da "litigância remanescente" ou, ainda, das questões normalmente não postas em juízo.

Essa visão da conciliação demasiada focada no acordo, desconsiderando outros objetivos da mediação, gera crítica por boa parte de práticos e teóricos dos meios de composição consensuais. Nesse, sentido, Fernanda Tartuce questiona:

A conciliação é muito atraente por liberar o magistrado de uma análise mais profunda do litígio, já que promove a "devolução da lide" às partes (que foram procurar o Poder Judiciário para uma definição e se vêem confrontadas a encontrar, por si próprias, uma saída de consenso).

O Poder Judiciário passa por intensa crise: com quase 80 milhões de processos em trâmite, tem sido muito difícil (em alguns casos, praticamente impossível!) cumprir a missão constitucional de distribuir justiça e afastar a incidência de lesões e ameaças de forma razoavelmente célere. Enquanto o tempo social revela-se cada vez mais acelerado, o tempo do processo se arrasta... eis mais um problema a ser cogitado e enfrentado pelas partes e por seus advogados quando da escolha do meio de composição de conflitos: a duração do processo.

Esses critérios, porém, são suficientes para a escolha da conciliação? É de se perguntar, portanto: para os jurisdicionados, a conciliação é a melhor saída? ${ }^{319,}$

Para a autora, conciliar vai muito além da obtenção do acordo, mas sim a obtenção de autêntico consenso, o que exige por parte do condutor da conciliação colaboração no sentido de identificar interesses e sugerir opções. Não seria conciliar (i) manter-se passivo em relação às propostas de acordo das partes; (ii) repetir discurso sobre as desvantagens da passagem judiciária (o que incita a desconfiança no Judiciário); (iii) insistir excessivamente na produção do acordo (o que gera baixo grau de legitimidade e adesão), resultando em uma pseudoautocomposição e, pior, sem as garantias de contraditório e ampla defesa do processo adjudicatório ${ }^{320}$.

319 TARTUCE, Fernanda. Conciliação e Poder Judiciário. Disponível em www.fernandatartuce.com.br. Acesso em: 05.10.2014.

320 TARTUCE, Fernanda. Conciliação e Poder Judiciário. Disponível em www.fernandatartuce.com.br. Acesso em:.05.10.2014. 
No PLS-SCD n. 166/2010, já aprovado no Congresso Nacional e aguardando sanção presidencial, o art. 165 diferencia os dois institutos da seguinte forma ${ }^{321}$ :

\begin{abstract}
$\S 2^{\circ} \mathrm{O}$ conciliador, que atuará preferencialmente nos casos em que não tiver havido vínculo anterior entre as partes, poderá sugerir soluções para o litígio, sendo vedada a utilização de qualquer tipo de constrangimento ou intimidação para que as partes conciliem;

$\S 3^{\circ} \mathrm{O}$ mediador, que atuará preferencialmente nos casos em que tiver havido vínculo anterior entre as partes, auxiliará aos interessados a compreender as questões e os interesses em conflito, de modo que eles possam, pelo restabelecimento da comunicação, identificar, por si próprios, soluções consensuais que gerem benefícios mútuos.
\end{abstract}

Nota-se que o projeto do novo CPC foca mais na diferença entre a condução do processo e no perfil de conflitos adequados a cada um dos tipos de meio consensual, o que é mais apropriado do que definir pelo resultado (acordo ou restabelecimento da comunicação), o que enfraquece a possível relação existente entre essas possíveis finalidades e a possibilidade de combinação de técnicas .

Portanto, é possível afirmar que, no Brasil, do ponto de vista cultural e, possivelmente, do ponto de vista normativo, essa diferenciação existe. Isso é adequado para o desenvolvimento de uma prática sólida de meios consensuais no Brasil?

$\mathrm{Na}$ literatura brasileira sobre meios consensuais, são diversas as posições. Para Paulo Eduardo Alves da Silva, a diferenciação deve ter relevância do ponto de vista prático, ou seja, diferenciar os institutos deve levar a um uso inteligente de cada um deles, saber as técnicas de cada um e aplicá-las segundo as necessidades do caso concreto ${ }^{322}$.

Entre os critérios para diferenciá-los estão:

(i) a mediação é indicada para conflitos envolvendo relações continuadas enquanto a conciliação é indicada para conflitos que só têm em comum entre si o próprio conflito;

(ii) a mediação serviria para conflitos não patrimoniais e a conciliação para conflitos patrimoniais;

(iii) a conciliação serviria para definição de um valor de acordo, enquanto a mediação faria uma composição mais completa do conflito;

(iv) a intervenção da conciliação é superficial e não trabalha as causas do conflito, enquanto a mediação busca a descoberta e o tratamento das causas do conflito.

\footnotetext{
${ }^{321}$ Conforme última versão consolidada disponível no site do Senado Federal, de 16/12/2014, que ainda não é a final, nem contempla todas as alterações ocorridas durante a sessão de votação. Disponível em: <http://www.senado.gov.br/atividade/materia/detalhes.asp?p_cod_mate=116731>. Acesso em: 31/12/2014.

322 SILVA, Paulo Eduardo Alves da. Mediação e conciliação, produtividade e qualidade. Revista do Advogado. São Paulo, AASP, n. 123, ago./2014, p. 40-47, p. 41.
} 
Segundo o autor, não há como falar em incorreção dos critérios de diferenciação de mediação e conciliação, mas sim em utilidade ou não para a articulação das técnicas de condução do procedimento consensual ${ }^{323}$.

Assim, a despeito das críticas envolvendo a diferenciação "à brasileira" entre conciliação e mediação, baseadas sobretudo na inexistência dessa diferenciação na literatura estrangeira, cremos que o Brasil possui cultura jurídica e de tratamento de conflitos suficientemente típica a embasar o desenvolvimento próprio e autônomo de suas categorias de intervenção consensual, bem como que a forma como os métodos consensuais vêm se desenvolvendo em nossa prática mostra que a distinção se afigura útil do ponto de vista das suas funcionalidades.

A princípio, demandas que envolvam relações pontuais e questões patrimoniais exigem intervenções mais focadas nos próprios resultados práticos do método de composição, na construção da própria solução, e menos foco na construção da relação entre as partes e resolução das questões subjacentes ao conflito. Muitas vezes, é o caso da administração pública, em que a necessidade de garantir a isonomia impõe o limite à consideração de elementos subjetivos que não sejam os mesmos estabelecidos para os demais indivíduos.

É importante, por outro lado, reconhecer também a existência de zonas cinzentas entre as intervenções, dadas pelos próprios conflitos, que podem surpreender o mediador/conciliador na condução da intervenção. Os conflitos tipicamente patrimoniais e que envolvam relações efêmeras podem revelar, por exemplo, um elemento de reconhecimento pessoal ou coletivo que justifique aprofundar no trato das razões do conflito e possa adicionar pautas que seriam, a princípio, estranhas a uma intervenção superficial.

De outra mão, o tratamento profundo de um conflito entre casal que está se divorciando pode chegar a um esgotamento tal que se torne impossível, pela mediação, alcançar o objetivo imediato pretendido (e muitas vezes necessitado) pelas partes, qual seja a dissolução do vínculo conjugal. A partir daí, pode se mostrar necessária uma intervenção mais objetiva que proponha soluções precisas aos pontos de divergência.

Nessa ideia de utilidade da diferenciação dos instrumentos, Paulo Alves Eduardo da Silva propõe, em um primeiro momento, identificar as características comuns aos dois

${ }^{323}$ SILVA, Paulo Eduardo Alves da. Mediação e conciliação, produtividade e qualidade, cit., p. 40-47, p. 41. 
instrumentos: ambos teriam a negociação como base e o acordo como finalidade ${ }^{324}$; ambos contariam com a intervenção de um terceiro, cujo objetivo não é descobrir a verdade para julgar, como na adjudicação, mas sim com a finalidade de identificar uma zona de convergência de interesses ${ }^{325}$.

Assim, ambos os métodos buscam a solução do conflito pelo consenso, e é na atividade do terceiro para a obtenção do consenso que se terá a diferença entre eles. $\mathrm{Na}$ conciliação, busca-se um consenso entre duas pessoas que não mantêm relação permanente, e o acordo que se busca é simples, geralmente patrimonial, e permite que ambas sigam em frente. A atuação do terceiro é voltada à busca de um arranjo que seja factível e de comum interesse.

Já na mediação, a questão patrimonial não é a única envolvida, e o acordo não mira apenas satisfação da questão objetiva, pois o relacionamento das partes continuará, o que exigirá do mediador uma imersão maior nas raízes do conflito. Deverá conhecer as partes e a dimensão do conflito, não bastando encontrar uma faixa de acordo de comum interesse ${ }^{326}$.

A partir daí, questões sobre a conduta do conciliador seriam ocasionais e definidas pelo caso na mesa, como as atividades das partes e do mediador/conciliador são dadas em forma de princípios (cooperação, boa-fé, criatividade) e, excepcionalmente, são dadas por regras de procedimento ${ }^{327}$.

Não obstante o autor entenda que a conduta propositiva seja contingencial, não variando de acordo com o método escolhido, a tendência, legislativa ${ }^{328}$ e doutrinária ${ }^{329}$ é de ter exatamente nesse ponto a distinção principal entre os procedimentos de conciliação e mediação.

Em conclusão, existe uma diferenciação cultural no Brasil hoje e um tratamento diferenciado pelos órgãos responsáveis pela solução de conflitos, mormente o Poder Judiciário. A divisão entre mediação e conciliação é, inclusive, insuficiente, pois existem diversas gradações e técnicas de condução da comunicação, com diferentes objetivos, que

\footnotetext{
${ }^{324}$ SILVA, Paulo Eduardo Alves da. Mediação e conciliação, produtividade e qualidade, cit., p. 40-47, p. 42.

${ }^{325}$ SILVA, Paulo Eduardo Alves da. Mediação e conciliação, produtividade e qualidade, cit., p. 40-47, p. 42.

${ }^{326}$ SILVA, Paulo Eduardo Alves da. Mediação e conciliação, produtividade e qualidade, cit., p. 40-47, p. 43. Esse é um critério proposto também por Juan Carlos Vezzulla (Cf. VEZZULLA, Juan Carlos. Mediação: Teoria e prática; Guia para utilizadores profissionais. Barcelos (Portugal): Agora Publicações, 2001, p. 83).

${ }^{327}$ SILVA, Paulo Eduardo Alves da. Mediação e conciliação, produtividade e qualidade, cit., p. 40-47, p. 44.

${ }^{328}$ Note que é essa a diferenciação adotada no foi adotado no PLS-SDC n. 166/2010, já aprovado.

${ }^{329}$ Cf. TARTUCE, Fernanda. Conciliação em juízo: o que (não) é conciliar? SALLES, Carlos Alberto; LORENCINI, Marco Antônio Garcia Lopes; SILVA, Paulo Eduardo Alves da. Negociação, mediação e arbitragem: curso básico para programas de graduação em Direito. São Paulo: Método, 2013, p. 149-177, p. $150-151$.
} 
não se resumem a (i) focar no acordo ou (ii) focar no relacionamento ou em qualquer outra colocação dicotômica. Todavia, essa mínima diferenciação é útil na medida em que se distinguem diferentes técnicas adequadas a diferentes profundidades de intervenção e a diferentes perfis de conflito.

A distinção a partir do tipo de relação entre as partes (se pré-existente ou ocasional) e o grau da atitude propositiva do terceiro parecem úteis do ponto de vista de construção e de adoção de técnicas. Na medida em que a mediação, como deve compreender com maior profundidade o conflito interpessoal, demandará técnicas mais adequadas para tanto, na conciliação, sendo válida a formulação de propostas, são necessárias técnicas apropriadas para a manutenção da imparcialidade nessa atividade.

Por outro lado, não parece correto tratar as duas figuras de forma estanque, porque o tratamento adequado de cada conflito pode revelar a necessidade de uso de técnicas mistas. Por isto, a pessoa habilitada a atuar como conciliador ou mediador deve ter esse arsenal de diferentes técnicas à sua disposição.

\subsubsection{Conciliação}

"Conciliação" é termo emprestado do Direito Italiano (conciliazione), enquanto "mediação" (mediation) é termo corrente nos países de língua inglesa da common law.

A conciliação pode ser (i) judicial/processual ou (ii) extrajudicial. No primeiro caso, está envolvida a autoridade judiciária, diretamente na realização da conciliação, na figura de seu próprio juiz ou de seus auxiliares ${ }^{330} \mathrm{ou}$, ao menos, na validação do resultado final. É a conciliação que ocorre no âmbito dos serviços oferecidos pelo Poder Judiciário.

Quanto à sua forma de atuação, a conciliação é bem explicada por Adolfo Braga Neto. Para o autor, esse procedimento, em primeiro lugar, não requer conhecimento aprofundado sobre a relação entre as partes, pois normalmente ela não é pré-existente. Em regra, como visto, é técnica que incide sobre conflitos em que as partes se relacionaram

\footnotetext{
${ }^{330}$ Interessante notar, nesse ponto, que o PLS-SCD n. 166 de 2010, recém-aprovado pelo Senado Federal e que substitui o Código de Processo Civil, lista os conciliadores e mediadores como auxiliares da Justiça, enquanto o atual CPC é omisso quanto a esses personagens: “Art. 149. São auxiliares da Justiça, além de outros cujas atribuições sejam determinadas pelas normas de organização judiciária, o escrivão, o chefe de secretaria, o oficial de justiça, o perito, o depositário, o administrador, o intérprete, o tradutor, o mediador, o conciliador judicial, o partidor, o distribuidor, o contabilista e o regulador de avarias" (grifos nossos). (Conforme última versão consolidada disponível no site do Senado Federal, de 16/12/2014, que ainda não é a final, nem contempla todas as alterações ocorridas durante a sessão de votação. Disponível em: <http://www.senado.gov.br/atividade/materia/detalhes.asp?p_cod_mate=116731>. Acesso em: 31/12/2014).
} 
ocasionalmente (acidentes de veículos, relações de consumo, etc.), em que o conflito em si é única razão de convívio entre as partes. Elas não se relacionaram nem se relacionarão após a composição do conflito.

Além disso, em segundo lugar, é dado ao conciliador fazer sugestões e estimular a reflexão e a avaliação sobre elas. Evidentemente, não são vinculativas e recomenda-se ao conciliador deixar as partes livres para fazer a sua própria reflexão. Essa técnica é favorecida pelo perfil dos conflitos tidos como adequados à conciliação.

Em terceiro lugar, ainda segundo Adolfo Braga Neto, o procedimento é simplificado, constituindo-se normalmente de uma única reunião e seu desenvolvimento deve se dar em momentos lógicos: apresentação; esclarecimentos sobre o conflito, momento de atuação do conciliador por meio especialmente de perguntas e estímulo da reflexão; criação de opções de composição; elaboração do acordo ${ }^{331}$.

Finalmente, para o autor, a necessidade que move a conciliação é a participação de um terceiro que ajude as partes a refletir sobre a melhor solução para a controvérsia e uma melhor avaliação sobre os riscos de buscar uma via heterocompositiva ${ }^{332}$.

O caráter mais simplificado e menos aprofundado da conciliação tem-na feito prevalecer no âmbito do Judiciário brasileiro. Em pesquisa empírica realizada por Daniela Monteiro Gabbay sobre programas de mediação e conciliação no Judiciário brasileiro, a autora notou que, quanto maior o volume de demandas submetidas ao programa, mais ele tende a ser um programa de conciliação e não de mediação, método que aprofunda o trabalho da relação entre as partes, exige mais de uma sessão e, portanto, mais tempo de dedicação ${ }^{333}$.

Não obstante seja verificado que, no âmbito de disputas repetitivas, o mecanismo mais utilizado seja a conciliação, focada no conflito objetivo e mais voltada à análise do prognóstico do possível desfecho de uma demanda judicial em comparação com a margem de negociação, Maria Cecília de Araújo Asperti enxerga espaço, nesse tipo de conflito,

331 BRAGA NETO, Adolfo. Reflexões sobre a conciliação e a mediação de conflitos. SALLES, Carlos Alberto de (coor.). As grandes transformações do processo civil brasileiro. São Paulo: Quartier Latin, 2009, p. 488-508, p. 491-494.

332 BRAGA NETO, Adolfo. Reflexões sobre a conciliação e a mediação de conflitos. SALLES, Carlos Alberto de (coor.). As grandes transformações do processo civil brasileiro, cit., p. 488-508, p. 491-492.

333 GABBAY, Daniela Monteiro. Mediação e Judiciário: Condições necessárias para a institucionalização dos meios autocompositivos de solução de conflitos. Tese de Doutorado, Faculdade de Direito da USP, 2011, p. 50 . 
para a utilização de técnicas próprias da mediação que possibilitem o aprofundamento nas suas causas mais subjetivas, que apareçam incidentalmente ${ }^{334}$.

\subsubsection{Mediação}

A mediação "consiste na atividade de facilitar a comunicação entre as partes para propiciar que estas próprias possam, visualizando melhor os meandros da situação controvertida, protagonizar uma solução consensual"335.

Esse meio consensual, na acepção em que adotamos nesse trabalho e que contém certo consenso entre aqueles que estudam e escrevem sobre meios consensuais, está ligado predominantemente à promoção do diálogo, compreensão e recuperação da relação entre as partes. Segundo Adolfo Braga Neto, é nada mais que "um processo em que o mediador coordena reuniões conjuntas ou individuais com as partes, com o fim de promover o diálogo na busca de soluções baseadas em seus respectivos interesses" ${ }^{336}$.

Essa concepção de mediação tem, no Brasil, forte influência do autor argentino Juan Carlos Vezzulla, que desenvolveu sua compreensão sobre mediação pautada (i) no integral reconhecimento da autonomia dos envolvidos, que devem conduzir o procedimento $^{337}$; (ii) no trabalho sobre as relações existentes entre os participantes e tratamento integral dos conflitos interpessoais; (iii) na satisfação de todos os participantes envolvidos $^{338}$.

A obtenção do acordo é apenas um dos objetivos. Caso os participantes não cheguem a ele, a mediação terá cumprido outros objetivos, que são os de esclarecimento do conflito e a aprendizagem do diálogo de forma respeitosa e produtiva ${ }^{339}$.

\footnotetext{
334 ASPERTI, Maria Cecília de Araújo. Meios consensuais de resolução de disputas repetitivas: a conciliação, a mediação e os grandes litigantes do Judiciário. Dissertação (Mestrado) - Faculdade de Direito da Universidade de São Paulo. São Paulo, 2014, p. 151.

335 TARTUCE, Fernanda. Mediação nos conflitos civis, cit., p. 208.

336 BRAGA NETO, Adolfo. Reflexões sobre a conciliação e a mediação de conflitos. SALLES, Carlos Alberto de (coor.). As grandes transformações do processo civil brasileiro, cit., p. 488-508, p. 497.

337 "A base da mediação é o tratamento dos mediados como seres humanos únicos que devem esclarecer as suas dificuldades melhorando as inter-relações que lhes permitem deter o controle absoluto de todas as etapas do processo, através de um diálogo esclarecedor que possibilite a negociação e pelo qual eles criam responsavelmente as soluções para não serem escravos de soluções impostas. A filosofia da mediação é que as pessoas envolvidas num conflito são as que melhor sabem como resolvê-los” (VEZZULLA, Juan Carlos. Mediação, cit., 2001, p. 87).

${ }^{338}$ VEZZULLA, Juan Carlos. Mediação, cit., p. 86-87.

${ }^{339}$ VEZZULLA, Juan Carlos. Mediação, cit., p. 87-88.
} 


\subsubsection{Transação vs. conciliação e mediação}

O termo transação normalmente sugere que o ato de transigir é um ato tolerante, que abre mão de algo pelo bem do acordo. A previsão do Código Civil reforça essa ideia: segundo o art. 840, "é lícito aos interessados prevenirem ou terminarem o litígio mediante concessões mútuas".

Como já visto, a transação é negócio jurídico normalmente relacionado com uma das formas possíveis de autocomposição em juízo e fora dele, ao lado das figuras do "reconhecimento jurídico do pedido" (art. 269, inciso II, do CPC) e da "renúncia ao direito em que se funda a ação" (art. 269, inciso V, do mesmo diploma legal).

$\mathrm{Na}$ transação, teríamos uma composição por concessão recíproca; no reconhecimento jurídico do pedido, a concessão é inteiramente feita pelo réu, e, na renúncia, ela é feita inteiramente pelo autor. Não há propriamente uma forma de extinção do processo por autocomposição que não implique, em sua definição normativa, concessão por alguma das partes ${ }^{340}$.

No entanto, já se sustentou que a solução consensual do conflito é possível sem concessões. É este, inclusive, o princípio que inspirou um dos mais conhecidos métodos de negociação, qual seja a negociação baseada em princípios (método de Harvard) ${ }^{341}$. Indagamos, em outra oportunidade, se não haveria, então, alguma imprecisão nas definições normativas dos possíveis resultados da autocomposição e, mais especificamente, no conceito de transação ${ }^{342}$.

Um dos questionamentos feitos é: se a transação é negócio pelo qual um litígio é prevenido ou resolvido mediante concessões recíprocas, qual seria o objeto das concessões?

Para afirmar seguramente, por exemplo, que as partes estivessem concedendo parte de seu direito, seria necessário que estes já estivessem reconhecidos com caráter de definitividade (através de um título judicial, por exemplo). E, como se sabe, a maior parte dos litígios não se encontra em tal grau de maturação da certeza do direito. Pelo contrário, os litígios justamente existem porque há uma crise de incerteza do direito, que necessita de

\footnotetext{
${ }^{340}$ Neste sentido, cf.: DINAMARCO, Cândido Rangel. Manual das pequenas causas. São Paulo: RT, 1986, p. 77.

${ }^{341}$ Cf. FISHER, Roger; URY, William; PATTON, Bruce. Getting to Yes, cit..

342 TARTUCE, Fernanda; BERGAMASCHI, André Luís. A solução negociada e a figura jurídica da transação: associação necessária? SIMÃO FILHO, Adalberto; MEDEIROS NETO, Elias Marques de; FIGUEIRA, Janahim Dias (coor.). Direito dos negócios aplicado, cit.(no prelo).
} 
sentença judicial para dirimi-la. A concessão de um direito, portanto, não pode ser elemento definidor da transação ${ }^{343}$.

É mais precisa a definição de Maria Helena Diniz nesse tocante:

\begin{abstract}
“A transação é um negócio jurídico bilateral, pelo qual as partes interessadas, fazendose concessões mútuas, previnem ou extinguem obrigações litigiosas ou duvidosas. (...) A transação seria uma composição amigável entre os interessados sobre seus direitos, em que cada qual abre mão de parte de suas pretensões, fazendo cessar as discórdias ${ }^{344}$.

A transação é um instituto jurídico sui generis, por consistir numa modalidade especial de negócio jurídico bilateral, que se aproxima do contrato (RT, 277:266; RT, 117:407), na sua constituição, e do pagamento, nos seus efeitos. É um negócio jurídico bilateral declaratório, uma vez que, tão-somente, reconhece ou declara direito, tornando certa uma situação jurídica controvertida e eliminando a incerteza que atinge um direito ${ }^{345}$.
\end{abstract}

A transação recairia, portanto, sobre as pretensões das partes e não sobre seus direitos ou interesses de fundo. Pelo contrário, ela é forma consensual de se reconhecer direitos, conferindo-os às partes e nem sempre abrindo mão deles. Assim, não é da essência da autocomposição e da solução consensual de conflitos a existência de "concessões mútuas" - nem de direitos, pois estes normalmente não estão definidos, nem de interesses, pois é possível construir arranjos negociais que atendam aos interesses de ambas as partes da mesma forma que suas pretensões poderiam (ou não) atender ${ }^{346}$.

Desse modo, em uma solução consensual de litígios, não há, necessariamente, “concessões recíprocas”, e, portanto, não há relação necessária entre tal solução e a transação em seu conceito legal. Em outra oportunidade, sugerimos dois caminhos a fim de desembaraçar a associação entre solução consensual e "concessão":

O primeiro implica simplesmente passar a utilizar o conceito de transação como "negócio jurídico que extingue ou previne litígios" suprimindo-se a menção a "concessões recíprocas" e reconhecendo que a transação mais se assemelha a um contrato como amplo espaço de liberdade das partes para construção e rearranjo de obrigações jurídicas.

O segundo caminho implica admitir que existam outras formas de solução consensual que não envolvam abrir mão de direitos e interesses, reservando a figura jurídica da transação para aqueles casos em que efetivamente verifica a transação - o que efetivamente ocorre, por exemplo, no acordo feito em sede de execução em que o

343 TARTUCE, Fernanda; BERGAMASCHI, André Luís. A solução negociada e a figura jurídica da transação: associação necessária? SIMÃO FILHO, Adalberto; MEDEIROS NETO, Elias Marques de; FIGUEIRA, Janahim Dias (coor.). Direito dos negócios aplicado, cit.(no prelo).

${ }^{344}$ DINIZ, Maria Helena. Curso de Direito Civil Brasileiro. 19. ed. São Paulo: Saraiva, 2004, v. 2, p. 324 325.

${ }^{345}$ DINIZ, Maria Helena. Curso de Direito Civil Brasileiro, cit., p. 331.

346 TARTUCE, Fernanda; BERGAMASCHI, André Luís. A solução negociada e a figura jurídica da transação: associação necessária? SIMÃO FILHO, Adalberto; MEDEIROS NETO, Elias Marques de; FIGUEIRA, Janahim Dias (coor.). Direito dos negócios aplicado, cit. (no prelo). 
exequente confere um desconto ao executado em troca do pagamento à vista da dívida $^{347}$.

Essa dissociação entre "concessão" e "solução consensual" pode ajudar, ao menos do ponto de vista teórico, a se pensar em mecanismos consensuais que possam atender a finalidades públicas sem necessariamente "transacionar" ou "abrir mão" de bens e valores da Administração Pública.

\subsection{Combinação de ferramentas de solução de conflitos: Case management ou} gerenciamento de processos.

No contexto de adequação da ferramenta ao conflito a ser resolvido, admite-se uma gradação entre meios puramente adjudicatórios e outros essencialmente consensuais, seja combinando diferentes técnicas, seja desenvolvendo ferramentas acessórias a um processo adjudicatório ou consensual.

Na condução dos processos judiciais, merece destaque a ideia de case management, ou gerenciamento de processo, que não configura exatamente um meio alternativo de solução de conflitos, pois envolve mais elementos. É, na verdade, um modelo de condução processual que se baseia em dois tipos de técnicas: (i) as de condução racional e organizada do processo judicial, com flexibilização e dinamização processual; e (ii) a utilização de meios alternativos, consensuais ou não, de solução, aproveitando os bons resultados daqueles para a boa condução deste, ainda que não se tenha resultado em $\operatorname{acordo}^{348}$.

Interessa-nos, no presente trabalho, sobretudo o segundo elemento, que é o uso de meios consensuais, fortemente estimulados no case management. Nesse modelo, segundo Paulo Eduardo Alves da Silva, tanto as partes quanto o juiz e seus auxiliares podem encaminhar o caso à resolução alternativa e indicar o meio adequado. Os modelos de case management, segundo o autor, por um lado estabelecem momentos processuais constantes

347 TARTUCE, Fernanda; BERGAMASCHI, André Luís. A solução negociada e a figura jurídica da transação: associação necessária? SIMÃO FILHO, Adalberto; MEDEIROS NETO, Elias Marques de; FIGUEIRA, Janahim Dias (coor.). Direito dos negócios aplicado, cit. (no prelo).

${ }^{348}$ SILVA, Paulo Eduardo Alves da. Condução planejada dos processos judiciais: a racionalidade do exercício jurisdicional entre o tempo e forma do processo. Tese de Doutorado, Faculdade de Direito da USP, 2005 , p. 59. No mesmo sentido: GAJARDONI, Fernando da Fonseca; ROMANO, Michel Betenjane; LUCHIARI, Valeria Ferioli Lagrasta. O gerenciamento do processo. GRINOVER, Ada Pellegrini; WATANABE, Kazuo; LAGRAStA NETO, Ceatano. Mediação e Gerenciamento do Processo. Rio de Janeiro: Atlas, 2007, p. 19-20. 
para a possibilidade de aplicação de ADRs (arbitragem judicial, conciliação, avaliação neutra de terceiros, etc.). Por outro, demandam planejamento e condução pelos agentes envolvidos, pois tanto a solução adjucatória tradicional quanto a alternativa dependem dessa atividade ${ }^{349}$.

Segundo Kazuo Watanabe, independentemente de o processo resultar ou não em composição, o fato de ele ser planejado já conduz para um julgamento com maior eficiência e menor custo. Esse é, na verdade, o fundamento do art. 331 do CPC e da previsão da audiência preliminar, que não teve a aplicação adequada pelos operadores do processo $^{350}$.

Justificando um modelo de gerenciamento de processos que envolva a inserção de métodos consensuais, Gajardoni et al. observam que o gerenciamento contribui para que o juiz conheça mais a fundo a questão controvertida, e possa buscar, de forma séria e consciente, a conciliação ou outras formas alternativas de solução do litígio, ou, quando frustrados seus intuitos de autocomposição, proferir uma sentença de boa qualidade ${ }^{351}$.

Em São Paulo, foram identificados projetos-piloto de gerenciamento prevendo a inclusão da mediação nas práticas gerenciais do processo ${ }^{352}$. Pesquisa empírica realizada por Paulo Eduardo Alves da Silva nos cartórios da justiça comum do estado de São Paulo revelou, em primeiro lugar, um modelo de condução de processos baseado em uma sessão prévia de conciliação, com fundamento legal no art. 125, inciso IV, do CPC.

Comparecendo o réu e não havendo acordo, inicia-se o prazo para defesa. Segundo um juiz entrevistado, nesse modelo, a maioria dos casos chegava a um acordo. Há casos em que o juiz conduz as conciliações. Há outros casos em que o a audiência prévia de conciliação é conduzida por um corpo de mediadores, especializados e treinados em técnicas dessa natureza, como é o caso do Setor de Conciliação do Foro Central Cível da Comarca de São Paulo. Segundo informações do próprio Setor, cerca de trinta por cento dos processos chega a acordo 353 .

Nas palavras do autor,

\footnotetext{
${ }^{349}$ SILVA, Paulo Eduardo Alves da. Condução planejada dos processos judiciais, cit., p. 59.

350 WATANABE, Kazuo. Cultura de sentença e Cultura de Pacificação. YARSHELL, Flávio Luiz (coor.). Estudos em homenagem à Professora Ada Pellegrini Grinover. São Paulo: DPj, 2005, p. 689.

351 GAJARDONI, Fernando da Fonseca; ROMANO, Michel Betenjane; LUCHIARI, Valeria Ferioli Lagrasta. O gerenciamento do processo. GRINOVER, Ada Pellegrini; WATANABE, Kazuo; LAGRASTA NETO, Ceatano. Mediação e Gerenciamento do Processo, cit., p. 19-20.

${ }^{352}$ GABBAY, Daniela Monteiro. Mediação e Judiciário, cit., p. 159.

${ }^{353}$ SILVA, Paulo Eduardo Alves da. Condução planejada dos processos judiciais, cit., p. 151.
} 
"A escolha por um modelo em que o juiz ou um profissional habilitado conduza a sessão é mais que uma escolha entre presença de autoridade estatal ou tempo disponível do juiz. É uma opção ditada especialmente pela habilidade necessária à condução dessa sessão e, infelizmente, pela estrutura disponível do juiz"354.

Outro exemplo foi o Projeto-Piloto desenvolvido junto ao Centro Brasileiro de Estudos e Pesquisas Judiciais (CEBEPEJ), implantado, entre outras, na $2^{\text {a }}$ Vara da Comarca de Serra Negra/SP e na Vara Única de Patrocínio Paulista/SP, com os objetivos de equacionamento das atividades do magistrado e da unidade jurisdicional pela inserção de técnicas de mediação dos processos em curso.

Nesse modelo, a condução do caso foi dividida nas fases pré-processual e processual. Os casos foram divididos em circuitos: $1^{\circ}$ circuito (família, infância e juventude) e $2^{\circ}$ circuito (questões cíveis de caráter disponível). Na fase pré-processual, o projeto previa o engajamento do Promotor de Justiça da Comarca, do Defensor Público e dos servidores do Judiciário que efetuavam o atendimento ao público, como o da assistente social, que informava a pessoa e realizava a triagem dos $\operatorname{casos}^{355}$.

$\mathrm{Na}$ fase processual, caberia ao juiz despachar a qualquer momento, mas especialmente na análise da petição inicial, ao perceber a possibilidade de autocomposição, a fim de encaminhar ao Setor de Conciliação/Mediação. Após dez meses de implementação do modelo, verificou-se uma redução de dez a quinze por cento na distribuição, graças aos feitos resolvidos na sessão de conciliação da fase pré-processual. No $2^{\circ}$ circuito, $66 \%$ das audiências não se realizaram especialmente por falta do reclamado. Nas que ocorreram, houve acordo em $89 \%$. No $1^{\circ}$ circuito, utilizou-se pouco a pré-processual, mas houve acordo em $80 \%$; e na fase processual (mais utilizada), 93\% das audiências foram realizadas e $73 \%$ resultaram em acordo ${ }^{356}$.

Assim, devido à ausência do reclamado, mudou-se a estratégia: a carta-convite, utilizada como forma de chamamento do requerido para participar da sessão de composição, foi substituída pela carta com timbre do Poder Judiciário, remetida via correio $^{357}$.

Seria possível aplicar algum modelo semelhante a conflitos envolvendo a Administração Pública? Alguns elementos coletados na pesquisa doutrinária e empírica permitem acenar uma resposta positiva.

\footnotetext{
${ }^{354}$ SILVA, Paulo Eduardo Alves da. Condução planejada dos processos judiciais, cit., p. 59.

355 SILVA, Paulo Eduardo Alves da. Condução planejada dos processos judiciais, cit., p. 151.

${ }^{356}$ SILVA, Paulo Eduardo Alves da. Condução planejada dos processos judiciais, cit., p. 151.

${ }^{357}$ SILVA, Paulo Eduardo Alves da. Condução planejada dos processos judiciais, cit., p. 151.
} 
Em parte da doutrina pesquisada, aventa-se a existência de um dever da Administração Pública em avaliar a possibilidade de transigir em todo o litígio em que é parte, mediante uma análise fática e jurídica da pretensão, a fim de concluir se há possibilidade de realizar acordo ou se seria caso, ainda, de efetivo reconhecimento do direito pela Administração. Justifica-se tal posição pelos princípios da eficiência e da proporcionalidade $^{358}$.

Na pesquisa realizada, constatou-se que a distância entre o advogado público que exerce a representação processual e o órgão da Administração Pública que esteve envolvido diretamente no conflito pode ser um óbice não apenas para o efetivo exercício da atividade consensual, como também para a própria instrução e boa condução contenciosa do processo judicial.

A necessidade de um parecer jurídico que suporte a atuação do advogado público e, muitas vezes, a autorização para transigir pela autoridade competente também são fatores de desestímulo à opção pela via consensual.

Outra questão é que, uma vez citada a Administração Pública, deflagra-se a busca incessante por elementos de defesa. Identificou-se também, na fala de alguns membros da Procuradoria entrevistados, que o procurador situado no front da atuação contenciosa é fortemente influenciado e pressionado pela lógica contenciosa, pela reatividade e pela necessidade de defesa; estando bastante zeloso, inclusive, de sua responsabilidade pessoal pelo prazo e pela defesa da "indisponibilidade do interesse público". O volume de trabalho também não contribui para uma análise mais profunda da possibilidade de uma atuação que não seja a de resistência.

No caso da Administração Pública, sem prejuízo da organização interna das Procuradorias (nota-se, ainda, que a pesquisa revelou que, para determinadas causas, há núcleos próprios de análise da possibilidade de composição), poder-se-ia estabelecer momentos processuais específicos e estratégicos, planejadamente, para que, suspendendo o curso dos atos processuais voltados à solução adjudicatória, possibilitassem aos advogados públicos a análise sobre a possibilidade de composição consensual.

358 Cf.: GAZDA, Emmerson. Administração Pública em juízo: poder-dever de transigir. Revista da Associação dos Juízes Federais do Brasil, v. 23, nº. 83, p.131-158, jan/mar 2006. Disponível em: < http://www.revistadoutrina.trf4.jus.br/index.htm?http://www.revistadoutrina.trf4.jus.br/artigos/edicao010/em merson_gazda.htm>. Acesso: 04.07.2014 ; VOLPI, Elon Kaleb Ribas. Conciliação na Justiça Federal: A indisponibilidade do interesse público e a questão da isonomia. Revista da PGFN. Brasília, PGFN, ano 1, n. 2, p. 139-164, 2011, p. 154-156; GAMA, Evandro. Conciliação e transação nas causas de natureza tributária nos Juizados Especiais Federais. GUEDES, Emmerson Carús (org.). Juizados Especiais Federais. Rio de Janeiro: Forense, 2005, p. 242; SOUZA, Luciane Moessa de. Meios consensuais de solução de conflitos envolvendo entes públicos, cit., p. 175-179. 
Igualmente pode ser aproveitada a característica de que, em alguns casos, como na Comarca de São Paulo, as causas contra a Administração Pública estão concentradas em varas especializadas - no caso, todas situadas no Fórum Hely Lopes Meirelles (Varas da Fazenda Pública e dos Acidentes de Trabalho) -, o que facilita o estabelecimento de uma tentativa de gerenciamento específico para a Administração Pública.

No mais, como visto, a ausência de iniciativas para estimular a autocomposição pela Administração Pública, pelo Poder Judiciário e pela própria Administração não se sustenta mais pelos postulados teóricos de indisponibilidade, restando óbices culturais e operacionais cuja superação pode ser estimulada. 


\section{LIMITES À UTILIZAÇÃO DOS MEIOS CONSENSUAIS PELA ADMINISTRAÇÃO PÚBLICA}

Até o presente momento, buscou-se superar os óbices teóricos à adoção dos meios consensuais pela Administração Pública levantados a partir de construções teóricas e dogmáticas próprias do Direito Administrativo, entre eles: (i) a legalidade estrita; (ii) a supremacia do interesse público; e (iii) indisponibilidade do interesse público.

Demonstrou-se também que os meios consensuais de solução de conflitos, fora as vantagens de celeridade e baixo custo já defendidas à exaustão na literatura, são capazes de construir soluções positivas para o atendimento ao interesse público e que são possíveis composições que não implicam renúncia de interesses.

Superados tais óbices, concluiu-se que não existe uma "indisponibilidade" ampla e irrestrita do "interesse público", até porque essa é uma cláusula geral de conteúdo dificilmente identificado. O que existe sim é uma finalidade pública específica a cada ato da Administração, como o atendimento a determinado interesse coletivo ou a algum direito fundamental, que não pode ser desviada. Assim, mantendo essa finalidade, eventual conflito pode ser composto desde que se a preserve.

Destacou-se, ainda, que apesar da Administração Pública não estar sujeita a uma proibição geral de engajar em meios consensuais de solução de conflitos e exercer a autocomposição de forma bilateral, ela está condicionada por algumas limitações, pois, de fato, não segue o mesmo regime de atuação que o particular, estando sujeita a determinadas normas que visam assegurar o atendimento das finalidades da função administrativa e a preservação da própria Administração contra a veiculação de interesses meramente privados dos governantes ou de terceiros sem qualquer vínculo com a promoção do bem comum ou de direitos fundamentais.

Em pesquisa empírica envolvendo a investigação da possibilidade de utilização de Dispute System Design (DSD) para conflitos de interesse público, conduzida pela Escola de Direito da FGV em parceria com a Secretaria de Assuntos Legislativos do Ministério da Justiça (SAL), foram levantadas algumas dificuldades decorrentes da presença de entes públicos, a partir da observação de situações conflituosas de grande abrangência, entre elas: pagamento de dívidas através de precatório; limites à negociação pela Administração; receio em relação à responsabilidade pessoal do gestor público (sob o efeito das leis de 
responsabilidade fiscal e de improbidade administrativa); indisponibilidade do interesse público e a incerteza sobre a sua extensão, que contribui para que órgãos de controle e fiscalização (como o Ministério Público e o Tribunal de Contas) variem de opinião de acordo com o casuísmo ou as impressões pessoais; inafastabilidade da jurisdição e estímulo ao uso da via judicial; mobilização da burocracia da Administração pública, que impede uma resposta rápida ao conflito, pois não há mecanismos ágeis para obter autorização para uma decisão; dificuldade em assegurar a isonomia ${ }^{359}$.

Referidas restrições não deixam de ser limitações fáticas à celebração de acordos, pois são desincentivos que, apesar de não desautorizarem expressamente a autocomposição, na prática geram um óbice operacional ao Poder Público em chegar a uma solução consensual.

As hipóteses são semelhantes às levantadas no início do trabalho e identificadas na literatura sobre o tema. Para além daquelas questões que já foram tratadas (como indisponibilidade do interesse público) o presente capítulo tem como objetivo esmiuçar essas limitações da perspectiva teórica, verificar se a dogmática jurídica realmente leva à conclusão de que se trata de limitações insuperáveis e, na medida do possível, verificar a existência de soluções que viabilizem a utilização dos meios consensuais.

Naturalmente, para cada área de atuação da Administração Pública (órgãos de proteção ao meio ambiente, contratos administrativos, servidores públicos, área físcal, arrecadação tributária, etc.) existem condicionantes próprias. Aqui, pretendemos listar as condicionantes com algum grau de generalidade, que possam se aplicar à Administração Pública em geral ou, pelo menos, a um grande número de situações.

\subsection{Necessidade de autorização legal?}

No presente trabalho, já foi desenvolvida a evolução da compreensão sobre a legalidade administrativa, que chegou a um ponto onde a ação administrativa pode, ainda que não prevista explicitamente em lei, ser extraída dos mandamentos constitucionais.

A partir do postulado da ponderação, há muitos que sustentam a aplicação dos meios alternativos de solução de conflitos independentemente de expressa autorização

${ }^{359}$ CUNHA, Luciana Gross; GABBAY, Daniela Monteiro (coor.). O desenho de sistemas de resolução alternativa de disputas para conflitos de interesse público. Brasília: Secretaria de Assuntos Legislativos do Ministério da Justiça, 2011, p. 14, 75-76. 
legal, em vista do princípio constitucional da eficiência que, ponderado com o princípio da legalidade em sentido estrito, melhor atenderiam à concretização do interesse público primário $^{360}$. Essa noção está melhor desenvolvida nos textos sobre arbitragem, mas poderia ser transposta para demais meios alternativos, como a negociação direta, a mediação e a conciliação.

Há posições mais extremadas, que chegam a falar em um dever do Estado de submeter controvérsias à arbitragem por imperativo da eficiência decorrente da ponderação de princípios $^{361}$. No âmbito da arbitragem, muitos autores defendem que a autorização genérica para utilização do instrumento por pessoas capazes já é suficiente para atender à legalidade administrativa ${ }^{362}$.

A pergunta que se coloca é: atendido o interesse público que se busca com determinado ato que está envolto em situação conflituosa, é legítimo um acordo firmado independentemente de autorização legal? A pergunta pode, na verdade, ser dividida em três: (i) o instrumento a ser utilizado deve ser autorizado legalmente de forma específica ao ente público? (ii) o conteúdo do acordo deve estar delimitado na Lei? e (iii) o sujeito competente deve estar identificado pela lei?

Quanto à primeira pergunta, a doutrina consultada permitiu distinguir que a escolha por satisfazer determinada finalidade pública por um meio consensual em vez da judicialização do conflito e, ainda, a iniciativa de promover veículos próprios para resolução consensual de conflitos prescindem de lei, estando balizada, na verdade, por outras limitações da Administração Pública ${ }^{363}$. Não seria necessário, portanto, uma lei autorizando a Administração Pública a adotar a conciliação, a mediação ou a negociação direta, ou, ainda, a engajar-se em um modelo processual de gerenciamento, ou a instituir veículos próprios para solução ou prevenção de conflitos. Assim, caso um Município resolva criar uma Câmara de Conciliação para determinadas matérias ou caso opte pelo término de um litígio por acordo, não é necessária autorização legal para valer-se do instrumento. Estaria, portanto, dentro do espectro de discricionariedade da Administração

\footnotetext{
360 MONTEIRO, Alexandre Luiz Moraes do Rego; CASTRO, Leonardo Freitas de Moraes e. Direito Tributário e Arbitragem: uma análise da possibilidade e dos óbices ao juízo arbitral em matéria tributária no Brasil. Revista de Mediação e Arbitragem. São Paulo, RT, n. 23, p. 60-88, out./dez. 2009, p. 66.

361 MONTEIRO, Alexandre Luiz Moraes do Rego; CASTRO, Leonardo Freitas de Moraes e. Direito Tributário e Arbitragem: uma análise da possibilidade e dos óbices ao juízo arbitral em matéria tributária no Brasil. Revista de Mediação e Arbitragem. São Paulo, RT, n. 23, p. 60-88, out./dez. 2009, p. 80.

${ }^{362}$ LEMES, Selma. Arbitragem na Administração Pública. São Paulo: Quartier Latin, 2007, p. 91.

${ }^{363}$ SOUZA, Luciane Moessa de. Meios consensuais de solução de conflitos envolvendo entes públicos: negociação, mediação e conciliação na esfera administrativa e judicial. Belo Horizonte: Fórum, 2012, p. 141.
} 
como eleição de meio válido para atingir uma finalidade, desde que praticado pela autoridade competente.

Note-se, por exemplo, que a Câmara de Conciliação e Arbitragem da AdvocaciaGeral da União não foi prevista em lei: decorreu da própria competência do AdvogadoGeral da União prevista no art. $8^{\circ}$-C da Lei n. 9.028/95 $5^{364}$. Da mesma forma, no âmbito da Procuradoria-Geral do Município de São Paulo, foi instituída por Decreto do Prefeito a Câmara de Conciliação de Precatórios, a ser gerida pelo Procurador-Geral em razão da competência que lhe é dada pela Lei para transigir e firmar compromissos (Lei $\mathrm{n}^{\circ}$ 10.182, de 30 de outubro de 1986).

Contudo, há entendimento de que há situações em que a realização de transação, em seu sentido técnico, ou seja, de acordos que envolvam disposição de direitos prédefinidos, deve contar com habilitação legal expressa, autorizando especificamente a sua realização.

Para Baptista Júnior, “[q]uando a Administração não conta com habilitação legal expressa, a transação é possível, desde que o administrador não tome deliberações de disposição. (...) A transação é lícita desde que a Administração nada 'conceda",365.

Luciane Moessa de Souza, comentando o trecho, afirma que "[q]uando o autor fala em 'deliberações de disposição' ele quer se referir a 'renúncia', que seria impossível no caso - o que já não ocorre com a simples 'troca",366. Para a autora, a renúncia não coincide com a transação, que contempla, sim, apenas "troca" e, normalmente, com vantagens para Administração. Jefferson Carús Guedes, por sua vez, parece entender que mesmo a transação é exceção, e só se justifica na presença de lei ${ }^{367}$.

Da síntese desses entendimentos, teríamos duas situações:

\footnotetext{
${ }^{364}$ Art. $8^{\circ}$-C. O Advogado-Geral da União, na defesa dos interesses desta e em hipóteses as quais possam trazer reflexos de natureza econômica, ainda que indiretos, ao erário federal, poderá avocar, ou integrar e coordenar, os trabalhos a cargo de órgão jurídico de empresa pública ou sociedade de economia mista, a se desenvolverem em sede judicial ou extrajudicial. (Incluído pela Medida Provisória n ${ }^{\circ} 2.180-35$, de 2001) Parágrafo único. Poderão ser cometidas, à Câmara competente da Advocacia-Geral da União, as funções de executar a integração e a coordenação previstas neste artigo. (Incluído pela Medida Provisória $\mathrm{n}^{\circ}$ 2.180-35, de 2001)

365 BAPTISTA JÚNIOR, Onofre Alves. Transações administrativas. São Paulo: Quartier Latin, 2007, p. 514 apud SOUZA, Luciane Moessa de. Meios consensuais de solução de conflitos envolvendo entes públicos, cit., p. 172.

${ }^{366}$ SOUZA, Luciane Moessa de. Meios consensuais de solução de conflitos envolvendo entes públicos, cit., p. 172.

${ }^{367}$ GUEDES, Jefferson Carús. Transigibilidade de interesses públicos: prevenção e abreviação de demandas da Fazenda Pública. GUEDES, Jefferson Carús; SOUZA, Luciane Moessa de. Advocacia de Estado: questões institucionais para a construção de um Estado de justiça. Belo Horizonte: Fórum, 2009, p. 252 ,
} 
(i) a autocomposição que envolvesse renúncia, ou seja, em que a Administração abre mão de um crédito legítimo, ou de um bem de sua propriedade a priori indisponível, a composição deveria envolver autorização legal para tanto, ao menos dentro de alguns parâmetros. É por isso, por exemplo, que a Administração não pode simplesmente renunciar a um crédito fiscal sem que a lei a habilite para tanto ou cancelar uma dívida ativa legítima por acordo. Ocorre aqui, de fato, a falta de identidade entre o titular do direito e o agente público, que não poderia portanto dele abrir mão;

(ii) (ii) Por outro lado, os autores consultados entendem possível a transação independentemente de previsão legal quando há troca com vantagem para a Administração Pública ou em situações em que a Administração "nada conceda".

Outra questão é se a lei deve prever expressamente as balizas do acordo a ser firmado. Veremos abaixo que algumas normas de competência vêm acompanhadas de critérios de realização de acordos, expressamente autorizando sua celebração.

Contudo, entende-se que a ausência desse balizamento legal não impede a realização do acordo. Apenas seria necessária autorização legal nesse sentido se houvesse efetiva renúncia a bens ou direitos da Administração. Note-se, por exemplo, que no âmbito dos Juizados Especiais Federais, é a Portaria AGU n. 109/2007, expedida pelo AdvogadoGeral, autoridade competente para transigir e firmar acordos, que disciplina os critérios utilizados para sua celebração.

Ainda que as balizas legais sejam dispensáveis na maioria dos casos, em grandes estruturas a sua previsão é de todo recomendável para conferir segurança aos diversos níveis hierárquicos dos advogados públicos.

Também seria desnecessária qualquer prever legalmente acordos que simplesmente cumpririam a lei. Nesse sentido, destacamos caso julgado pelo Supremo Tribunal Federal, de relatoria da Ministra Ellen Gracie Northfleet, assim ementado:

Poder Público. Transação. Validade. Em regra, os bens e o interesse público são indisponíveis, porque pertencem à coletividade. É, por isso, o Administrador, mero gestor da coisa pública, não tem disponibilidade sobre os interesses confiados à sua guarda e realização. Todavia, há casos em que o princípio da indisponibilidade do interesse público deve ser atenuado, mormente quando se tem em vista que a 
solução adotada pela Administração é a que melhor atenderá à ultimação deste interesse. Assim, tendo o acórdão recorrido concluído pela não onerosidade do acordo celebrado, decidir de forma diversa implicaria o reexame da matéria fático-probatória, o que é vedado nesta instância recursal (Súm. 279/STF). Recurso extraordinário não conhecido $^{368}$.

Inserido no julgado, manifestou-se in casu a Procuradoria Geral de Justiça:

\begin{abstract}
"o acordo celebrado não é oneroso e nem gera gravame ao município, sendo despicienda autorização legislativa para tanto. Não é o caso de comprometimento de bens, afetacão de verbas, criacão de cargo novo ou inusitado aumento de despesas. É mero ressarcimento decorrente de sua responsabilidade. É pagamento de salário, pois, com caráter alimentar, reconhecido como indevidamente retido (...) $\mathrm{O}$ acordo celebrado pelas partes, quase três anos depois do início da ação, nada mais fez que antecipar a justiça. Ao reconhecer a procedência da ação, o Município-requerido apenas tentou minimizar os desastrosos efeitos ocasionados às autoras, ora apeladas, pela perseguição política anterior" (grifo nosso).
\end{abstract}

Outro fundamento levantado pelo acórdão para a possibilidade de transação em juízo independentemente de autorização legal, neste caso, é a utilização da autotutela, que o poder da Administração anular os atos ilegais praticados e revogar os inconvenientes e inoportunos, poderes já previstos em lei e que dispensam nova autorização.

Finalmente, a celebração de acordo envolvendo interesses públicos efetivamente tidos como indisponíveis, ou metaindividuais, não demanda autorização legal do seu conteúdo, pois os instrumentos para tanto (Termos de Compromisso) já são destinados a garantir o cumprimento da Lei ou exigir o atendimento de um interesse público. A realização de acordo envolvendo "direitos indisponíveis” no âmbito da Ação Civil Pública por promotores de justiça sequer demanda autorização legal específica (uma vez criado o instrumento consensual por Lei, sua utilização é livre) ou, ainda, autorização de órgãos superiores. Ao menos no Ministério Público de São Paulo, vige a Súmula de Entendimento n. 25 do Conselho Superior do Ministério Público: "Não há intervenção do Conselho Superior do Ministério Público quando a transação for promovida pelo Promotor de Justiça no curso de ação civil pública ou coletiva". A baliza é dada pelo próprio interesse a ser protegido pelo Ministério Público: o seu núcleo deve ser preservado e não pode ser objeto de renúncia. Bem esclarece Mancuso que

“[n]o âmbito da ação civil pública, deve sempre prevalecer o interesse na efetiva tutela dos valores maiores da sociedade civil, a que esse instrumento processual está vocacionado, de sorte que, se o objetivo colimado - proteção ou reparação ao interesse metaindividual ameaçado ou lesado - puder ser alcançado pela via consensual, com

368 SUPREMO TRIBUNAL FEDERAL. Recurso Especial n. 253885-MG. Órgão Julgador: Primeira Turma. Relatora: Min. Ellen Gracie, J. em: 04/06/2002. DJ em: 21/06/2002. 
economia de tempo e de custos, não há motivo plausível para se negar legitimidade a essa solução consensual"369.

De mesma forma em que há dissociação entre o titular do interesse tutelado e os legitimados para celebração de Termo de Ajustamento de Condutas (TAC) no âmbito da ação civil pública e do inquérito civil público, a Administração Pública, enquanto tem como função a promoção de medidas de interesse público (aí incluídos os direitos fundamentais), bem como legitimidade para a proteção de interesses metaindividuais (art. $5^{\circ}$, incisos III e IV, da Lei n. 7.347/1985), também está sujeita a não abrir mão do núcleo essencial do interesse perseguido, de forma que o "espaço transacional não inclui a parte substantiva da obrigação cominada ao infrator ou aquela a que se obrigou o responsável pela lesão ao interesse metaindividual" ${ }^{370}$.

Registre-se a posição de Ricardo de Barros Leonel, no sentido de que o compromisso de ajustamento melhor se amolda à autocomposição por submissão do que a transação, tendo em vista que o legitimado não pode renunciar aos bens a serem protegidos $^{371}$. A prática nos mostra, contudo, que a proteção do interesse em questão não significa que a posição adotada pelo legitimado em face do suposto causador de dano se identifica necessariamente com a extensão ou com a forma adequada de sua proteção. Isso quer dizer que o fato de o legitimado se arrefecer na sua posição inicial sobre a questão, demandando integral submissão do suposto causador do dano, não se identifica necessariamente com a tutela adequada do interesse. O espaço negocial propiciado pelos termos de compromisso é dialógico e, ainda que a negociação se dê com base na legalidade, o legitimado pode estar equivocado quanto às suas exigências e deve ouvir a outra parte quanto à sua compreensão do tema, revendo sua posição inicial se for o caso ${ }^{372}$.

No mais, como já expusemos, os meios consensuais não têm como resultado necessariamente renúncia ou transação; boa parte das situações submetidas a meios consensuais pode não envolvê-las, como: (i) reconhecimento de legítimos direitos pela

\footnotetext{
${ }^{369}$ MANCUSO, Rodolfo de Camargo. Ação Civil Pública. 13. ed. São Paulo: RT, 2014, p. 278.

${ }^{370}$ MANCUSO, Rodolfo de Camargo. Ação Civil Pública, cit., p. 290.

${ }^{371}$ LEONEL, Ricardo de Barros. Manual do processo coletivo. 2. ed. São Paulo: RT, 2011 , p. 350.

${ }^{372}$ Um dos casos narrados por uma Procuradora do Município na pesquisa empírica realizada foi uma proposta de Termo de Compromisso feita pelo Ministério Público do Trabalho em que se exigia da Prefeitura medidas para acabar com o trabalho infantil de engraxates no Aeroporto de Congonhas, tais quais a instalação de um posto avançado permanente de monitoramento e acompanhamento social. A Secretaria responsável, contudo, pronunciou-se dizendo ser inviável tecnicamente a instalação de posto permanente, por falta de recursos humanos para tanto. Concordou, por outro lado, em tomar outras medidas compensatórias e esse ponto foi revisto pelo Ministério Público. O TAC, contudo, acabou não frutificando por conta de divergências em relação às penalidades que seriam aplicadas ao Município.
} 
Administração (como no caso de revisão atos administrativos legais ou indenizações); (ii) assunção de obrigações pelo particular, com prazos e formas de cumprimento flexibilizados; (iii) construção consensual do sentido de normas que se valem de conceitos indeterminados, como "proteção integral à criança". Esses casos não necessitariam de balizas normativas, sendo salutar, inclusive para a segurança dos agentes públicos envolvidos ${ }^{373}$.

Questão diversa é a terceira formulada: a necessidade de previsão legal dos sujeitos autorizados a realizar acordos, envolvam eles ou não transação e renúncia. Para melhor desenvolver essa discussão, é necessário resgatar brevemente os conceitos de "ato administrativo" e "competência para o ato".

Marçal Justen Filho define o ato administrativo como "uma manifestação de vontade funcional apta a gerar efeitos jurídicos, produzida no exercício de uma função administrativa" ${ }^{, 374}$. Sendo uma manifestação de vontade funcional, não é a mesma vontade autônoma do direito privado, significando que a vontade está "objetivamente vinculada à satisfação das necessidades coletivas", do que decorre que: (i) haverá controle jurídico exacerbado sobre a formação da vontade estatal; (ii) a vontade psicológica não é suficiente para a existência e validade do ato; e (ii) deve haver compatibilidade objetiva entre a manifestação externa de vontade e a satisfação de necessidades coletivas ${ }^{375}$. Na manifestação de vontade da Administração Pública, que se dá por ato de algum dos seus agentes, há procedimentos e regras formais com a finalidade de evitar abusos e manter essa vinculação objetiva ${ }^{376}$.

O ato administrativo, ainda que composto de dois elementos (forma e conteúdo), depende da análise de outros aspectos para que seja considerado válido: motivo, requisitos procedimentais, finalidade, causa, formalização e sujeito. Interessa-nos aqui o sujeito ou agente, que é quem produz o ato administrativo ${ }^{377}$. Nesse assunto, emerge como relevante o conceito de competência administrativa, que é "a atribuição normativa da legitimação para a prática de um ato administrativo", limitada por natureza (não há competência ilimitada) e criada por lei (obediência ao princípio da legalidade), o que não a impede de

\footnotetext{
373 Note-se, por exemplo, que a realização de TAC no âmbito da Prefeitura de São Paulo foi procedimentalizada por Decreto, que passou a exigir, antes da celebração do acordo, dois requisitos: a viabilidade técnica, pronunciada pela Secretaria envolvida, e a viabilidade jurídica, emitida pela Procuradoria (Cf. Decreto Municipal n. 52.163/2011).

${ }^{374}$ JUSTEN FILHO, Marçal. Curso de Direito Administrativo, cit., p. 389.

375 JUSTEN FILHO, Marçal. Curso de Direito Administrativo, cit., p. 390-391.

376 JUSTEN FILHO, Marçal. Curso de Direito Administrativo, cit., p. 393.

377 JUSTEN FILHO, Marçal. Curso de Direito Administrativo, cit., p. 404-405.
} 
ser regulamentada por ato administrativo. Ainda, a competência é atribuída a uma função ou cargo, jamais a uma pessoa física específica ${ }^{378}$.

Como ensina Maria Sylvia Zanella Di Pietro, não havendo lei, entende-se que o competente é o Chefe de Poder Executivo, por ser ele a autoridade máxima da organização administrativa, concentrando a totalidade de competências não delegadas ${ }^{379}$. Interessa-nos especialmente a delegação de competência em que o superior hierárquico confere a seu subordinado uma atribuição que originariamente lhe pertence.

A realização de acordo em juízo (seja qual for seu resultado) e a realização de acordo fora dele (termos de compromisso nas diversas matérias, e composição em relação a outras controvérsias) devem também atender à identificação da competência.

A competência para autocomposição extrajudicial parece ser de difícil identificação. Se não foi criada competência específica para algum órgão ou função, devese procurar no emaranhado de normas do ente público quem deteria a competência para negociar sobre aquela matéria.

Em juízo, as leis orgânicas que organizam a advocacia do ente público normalmente já atribuem a seu superior hierárquico a competência para transigir ou realizar acordo em juízo. Vejamos alguns exemplos.

A Lei Complementar n. 73/93 (Lei Orgânica da Advocacia-Geral da União) cria a competência do Advogado-Geral da União para autorizar acordos em ações judiciais de interesse da União, mas a submete aos termos de lei própria (Lei n. 9.469/97), que, por sua vez, limita-a pelo valor:

“Art. $4^{\circ}$ - São atribuições do Advogado-Geral da União:

VI - desistir, transigir, acordar e firmar compromisso nas ações de interesse da União, nos termos da legislação vigente;

Art. $1^{\circ} \mathrm{O}$ Advogado-Geral da União, diretamente ou mediante delegação, e os dirigentes máximos das empresas públicas federais poderão autorizar a realização de acordos ou transações, em juízo, para terminar o litígio, nas causas de valor até $\mathrm{R} \$$ 500.000,00 (quinhentos mil reais)."

Na Lei Complementar Estadual n. 478, de 18 de julho de 1986 (Lei Orgânica da Procuradoria Geral do Estado de São Paulo), é prevista a delegação da competência ao

378 JUSTEN FILHO, Marçal. Curso de Direito Administrativo, cit., p. 406.

${ }^{379}$ DI PIETRO, Maria Sylvia Zanella. Direito Administrativo, cit., p. 192-193. Vale ressaltar que, em Direito Administrativo, "delegação" é termo plurívoco, sendo usada para se falar em "delegação de serviço público", "delegação de capacidade tributária", etc. Aqui os interessa a "delegação de competência administrativa", ou seja, para realização de atos administrativos. 
Procurador Geral, mas a submete à autorização do Governador: "Artigo $6^{\circ}$ - Compete ao Procurador Geral, sem prejuízo de outras atribuições previstas em lei ou regulamento: VI desistir, transigir, firmar compromisso e confessar nas ações de interesse da Fazenda do Estado, autorizado pelo Governador”.

Já no Município de São Paulo, a Lei n. 10.182, de 30 de outubro de 1986, prevê em seu art. $4^{\circ}$, inciso VI, a competência do Procurador Geral para "[c]onfessar, desistir, transigir, firmar compromissos e reconhecer pedidos nas ações de interesse da Fazenda Municipal, podendo delegar estas atribuições". Nota-se a ausência de restrições semelhantes.

É adequado que a Advocacia-Geral do ente público, sendo a responsável por representá-lo em juízo, tenha competência para a realização de acordos. Contudo, nada impediria de que a norma municipal atribuísse referida competência, por exemplo, à Secretaria Municipal pertinente ao conflito.

No entanto, a concentração da competência para a realização de acordos no superior hierárquico da advocacia é normalmente apontada como um óbice a um sistema de gestão de conflitos que priorize a consensualidade. Nas entrevistas realizadas, um óbice levantado por parte dos Procuradores do Município é a falta de autorização para que o procurador individualmente celebre um acordo em juízo. De fato, como visto, é inválido o ato administrativo praticado por quem não detém competência para tanto, e o procurador, para a solução consensual, deveria apresentar a possibilidade de acordo aos seus superiores e aguardar uma autorização, o que é um desestímulo para a condução diferenciada do processo judicial.

Esse é um dos motivos, dentre outros, pelos quais dificilmente se realizam, na prática, audiências de conciliação em juízo envolvendo a Administração Pública Municipal, conforme levantado na pesquisa empírica.

Um modelo interessante que viabiliza a prática é o da delegação limitada de poderes para transigir ao procurador que atua no dia-a-dia forense, estabelecendo faixas de valor ou matérias específicas em que o procurador pode celebrar acordo sem necessidade de autorização, geralmente voltadas a demandas mais simples, com entendimento mais uniformizado e teses relativamente superadas no Judiciário e no entendimento da própria Procuradoria $^{380}$.

\footnotetext{
${ }^{380}$ Esse é o modelo que a Advocacia-Geral da União vem adotando, conforme será melhor explicitado no item seguinte.
} 
Outro modelo é aquele no qual as questões mais complexas poderiam ser delegadas a um Colegiado e, ainda, depender de consulta a um segundo Colegiado. Este é o modelo consensual para celebração de Termos de Compromisso no âmbito da Comissão de Valores Mobiliários (CVM) que, ainda que assinado pelo Presidente da CVM (art. $3^{\circ}, \S^{\circ}$ da Deliberação CVM n. 390/2001), é deliberado em decisão final pelo seu Colegiado (arts. $3^{\circ}$ e $9^{\circ}$ ), após passar por exame do Comitê do Termo de Compromisso (art. $8^{\circ}$, caput), órgão que elabora o parecer sobre o caso e que poderá negociar (literalmente) com o interessado as condições do Termo $\left(\operatorname{art.} 8^{\circ}, \S^{\circ}\right)^{381}$.

Em síntese, a questão autorização legal para utilização dos meios consensuais se dá em três aspectos diferentes: (i) a previsão da adoção do instrumento consensual em si, que a princípio é desnecessária (apesar de recomendada), salvo se envolver atos de disposição efetiva; (ii) a autorização do acordo em si em determinadas matérias e previsão de suas balizas, exigida quando se tratar de efetiva concessão pelo ente público, e desejável a fim de suportar a atuação do administrador e do advogado público e garantir-lhes segurança jurídica; (iii) criação da competência para realização de composição de conflitos judicial ou extrajudicialmente, obrigatória, caso não se queira concentrar a função no Chefe de Executivo.

O baixo grau de regulamentação das hipóteses e balizas de acordo e o isolamento do profissional que conduz o processo judicial, contudo, ainda são apontados como questões que geram insegurança e, consequentemente, impedem uma maior cultura de utilização dos meios consensuais ${ }^{382}$.

\subsubsection{Panorama legal autorizativo da adoção de meios extrajudiciais e meios} consensuais pela Administração Pública

Não obstante as considerações tecidas ao final do tópico acima, existem hoje, em nosso direito positivo, normas que regulam a adoção de meios extrajudiciais e consensuais pela Administração Pública nas três vertentes indicadas: (i) criando mecanismos consensuais, (ii) estabelecendo critérios para a realização de acordos, e (iii) atribuindo

\footnotetext{
${ }^{381}$ Confira-se art. $8^{\circ}$ da Deliberação CVM n. 390, de 08 de maio de 2001: "Após ouvida a Procuradoria Federal Especializada, o Superintendente-Geral submeterá a proposta de termo de compromisso ao Comitê de Termo de Compromisso, que deverá apresentar parecer sobre a oportunidade e a conveniência na celebração do compromisso, e a adequação da proposta formulada pelo acusado, propondo ao Colegiado sua aceitação ou rejeição, tendo em vista os critérios estabelecidos no art. $9^{\circ}$ ".

${ }^{382}$ GUEDES, Jefferson Carús. Transigibilidade de interesses públicos: prevenção e abreviação de demandas da Fazenda Pública, cit., p. 252.
} 
competência a ocupantes de cargos específicos para realização de acordos. Na sequência, são listados os instrumentos e normas localizados.

Para a finalidade desse trabalho, entendeu-se conveniente identificar também os meios extrajudiciais que não constituem meios consensuais no conceito aqui adotado, para melhor configurar como vem se desenvolvendo uma "parajurisdicionalidade" na resolução de conflitos envolvendo a Administração.

\subsubsection{Adoção de mecanismos extrajudiciais de solução de conflitos}

Neste tópico, identificamos não apenas os meios consensuais propriamente ditos, mas também as autorizações legais (ou os debates acerca delas) para utilização de meios extrajudiciais adjudicatórios (v.g. a arbitragem, instituto já conceituado no capítulo anterior) pela Administração Pública. Apesar de não compor o objetivo específico dessa dissertação, esse levantamento contribui para demonstrar um panorama de direito positivo que tem se aberto à solução extrajudicial de controvérsias que envolvem a Administração Pública, relativizando a exclusividade do processo judicial como forma de composição de conflitos que envolvem entes públicos.

a) Previsão antiga identificada é a arbitragem entre o Estado Brasileiro e os organismos de financiamento internacionais. O Decreto-Lei n. 1.312/74 prevê:

Art. 11. O Tesouro Nacional contratando diretamente ou por intermédio de agente financeiro poderá aceitar as cláusulas e condições usuais nas operações com organismos financiadores internacionais, sendo válido o compromisso geral e antecipado de dirimir por arbitramento todas as dúvidas e controvérsias derivadas dos respectivos contratos.

b) Lei de licitações:

Há na Lei de Licitações a previsão de que é competente para o foro da sede da Administração para dirimir questões contratuais (art. 55,\$2 $2^{\circ}$, da Lei $8.666 / 93$ ), o que poderia denotar uma exclusividade do Poder Judiciário estatal para tais conflitos ${ }^{383}$.

${ }^{383}$ Há, contudo, boa resposta a tal argumento contrário ao cabimento da arbitragem: tratando-se do caso das PPPs, em que é necessário, segundo a Lei n. 8.987/95, que conste o foro de eleição como cláusula essencial do contrato, Luiza Rangel de Moraes afirma: "Não há, de fato, nem mesmo incompatibilidade quanto à eleição de foro, também prevista como cláusula essencial dos contratos de concessão, porquanto, embora a 
Por outro lado, debate-se se a Lei n. 8.666/93 não teria trazido uma autorização implícita para a adoção de qualquer método de solução de conflitos privado ou não no âmbito de licitações internacionais. $\mathrm{O}$ art. $42, \S 5^{\circ}$, da referida lei dispõe que

Para a realização de obras, prestação de serviços ou aquisição de bens com recursos provenientes de financiamento ou doação oriundos de agência oficial de cooperação estrangeira ou organismo financeiro multilateral de que o Brasil seja parte, poderão ser admitidas, na respectiva licitação, as condições decorrentes de acordos, protocolos, convenções ou tratados internacionais aprovados pelo Congresso Nacional, bem como as normas e procedimentos daquelas entidades, inclusive quanto ao critério de seleção da proposta mais vantajosa para a administração, o qual poderá contemplar, além do preço, outros fatores de avaliação, desde que por elas exigidos para a obtenção do financiamento ou da doação, e que também não conflitem com o princípio do julgamento objetivo e sejam objeto de despacho motivado do órgão executor do contrato, despacho esse ratificado pela autoridade imediatamente superior.

Nesse sentido, José Maria Rossani Garcez nos dá nota de que entidades multilaterias de financiamento, como o Banco Mundial e o Banco Interamericano de Desenvolvimento (BID) preveem, nos editais-padrão das licitações de obras e aquisição de bens e serviços por eles financiados, a utilização da arbitragem, existindo, contudo, posição restritiva do Tribunal de Contas da União (TCU) no sentido da impossibilidade da adoção dessa cláusula dos editais ${ }^{384}$.

c) Lei Geral de Concessões (Lei n. 8.987/95)

decisão arbitral seja definitiva e vinculativa, o árbitro ou Tribunal arbitral não tem poder de império. À Justiça estatal caberá, pois, desempenhar um imprescindível papel de apoio para assegurar a efetividade das decisões arbitrais. Ademais, compete também ao Poder Público a função de controlar a observância dos limites traçados pela Lei n. 9.307/96 - Lei de Arbitragem - e a de homologar a sentença arbitral estrangeira. Isso sem contar as hipóteses em que a disputa não for arbitrável, quando, então, será competente unicamente o Judiciário" (MORAES, Luiza Rangel de. Arbitragem e agências reguladoras. Revista de Arbitragem e Mediação, São Paulo, Revista dos Tribunais, n. 2, p. 74-89, mai./ago. 2004, p. 79-80.

${ }^{384}$ GARCEZ, José Maria Rossani. O Estado, suas agências, as empresas públicas e as sociedades de que participa na arbitragem privada. Recentes progressos. Revista de Arbitragem e Mediação, São Paulo, Revista dos Tribunais, n. 8, p. 101-118, jan./mar. 2006, p. 103-105. Confira-se o acórdão n. 1.099/2006, mais recente localizado na pesquisa junto ao TCU sobre o tema: "Da cláusula referente à fundamentação legal do contrato, consta que as partes contratantes submetem-se, além dos dispositivos da Lei $n^{\circ}$ 8666/1993, às disposições constantes das Normas de Aquisição do BID. Trata-se de disposição contratual nula e, portanto, indevida, notadamente quanto aos procedimentos de arbitragem para solução de eventuais controvérsias, previstos nos itens 24 e 25 - Condições Contratuais Gerais do BID, uma vez que incompatíveis com o interesse público e contrários ao estabelecido no artigo $1^{\circ}$ da Lei $^{\circ}$ 9.307/1996. Tal matéria, inclusive, já foi abordada no âmbito do TC $\mathrm{n}^{\circ}$ 004.031/2003-0, culminando no Acórdão $\mathrm{n}^{\circ}$ 587/2003 - Plenário, por meio do qual ficou pacificado que o interesse tutelado na relação jurídica contratual é, inquestionavelmente, de natureza pública, sendo, portanto, indisponível. Daí, então, a nulidade de cláusulas editalícias e contratuais que estabeleçam procedimentos de arbitragem para solução de controvérsias relacionadas aos ajustes administrativos para a elaboração de projetos e/ou execução de obras e/ou serviços de engenharia rodoviária (BRASIL. Tribunal de Contas da União. Acórdão n. 1099/2006. Órgão Julgador: Plenário. Relator: Augusto Nardes. J. em: 05/07/2006). 
$\mathrm{Na}$ redação original da Lei Geral de Concessões (Lei n. 8.987/95), que trata especificamente da prestação de serviços públicos mediante concessão do Poder Público ao particular, havia a seguinte previsão:

Art. 23. São cláusulas essenciais do contrato de concessão as relativas:

(...) XV - ao foro e ao modo amigável de solução das divergências contratuais.

A redação foi inicialmente considerada insuficiente para o uso da arbitragem, pois este não seria exatamente um modo amigável de solução de conflitos ${ }^{385}$. Havia abertura, portanto, para uso de meios amigáveis, pelo que se podia entender que os conflitos poderiam ser objeto de conciliação ou mediação.

De qualquer forma, a imprecisão foi integralmente corrigida pela Lei n. 11.196/05, que incluiu na mesma Lei de Concessões o art. 23-A, que prevê expressamente a possibilidade de opção pela arbitragem:

Art. 23-A. O contrato de concessão poderá prever o emprego de mecanismos privados para resolução de disputas decorrentes ou relacionadas ao contrato, inclusive a arbitragem, a ser realizada no Brasil e em língua portuguesa, nos termos da Lei no 9.307, de 23 de setembro de 1996.

d) Lei geral de telecomunicações (Lei n. 9.472/97):

Também nesta lei há previsão para adoção de solução extrajudicial:

Art. 93. O contrato de concessão indicará:

(...) XV - o foro e o modo para solução extrajudicial das divergências contratuais.

Revelou, de início, melhor técnica que a Lei de Concessões, ao tratar de "solução extrajudicial", que pode envolver tanto meios adjudicatórios, como a arbitragem, quanto “amigáveis" ou, melhor dizendo, consensuais.

Também há previsão específica de que a rescisão do contrato pode se dar de forma amigável, oferecendo uma alternativa à via judicial, ainda que não indique um procedimento para tanto.

Art. 115. A concessionária terá direito à rescisão quando, por ação ou omissão do Poder Público, a execução do contrato se tornar excessivamente onerosa.

Parágrafo único. A rescisão poderá ser realizada amigável ou judicialmente.

385 GLEBER, Eduardo. A solução de controvérsias em contratos de parceria público-privada. Revista de Arbitragem e Mediação, São Paulo, Revista dos Tribunais, n. 2, p. 60-73, mai./ago. 2004, p. 66. 
e) Lei de Política Energética Nacional (Lei n. 9.478/97):

Mais específica, essa lei prevê a possibilidade de "conciliação" e "arbitragem" para tratamento dos conflitos decorrentes das concessões previstas em lei:

Art. 43. O contrato de concessão deverá refletir fielmente as condições do edital e da proposta vencedora e terá como cláusulas essenciais:

(...) X - as regras sobre solução de controvérsias, relacionadas com o contrato e sua execução, inclusive a conciliação e a arbitragem internacional;

Aqui, contudo, há certa discussão sobre os limites do uso de meios extrajudiciais, especialmente a arbitragem: a referida lei não trata da concessão de serviços públicos, mas sim a concessão que designa um contrato "pelo qual a União Federal delega a sociedades de economia mista e empresas privadas o direito de explorar e produzir petróleo e gás natural". A concessão de serviço público representaria a delegação do Estado para o particular prestar um serviço de interesse público ${ }^{386}$. Já o que ocorre com exploração e produção de petróleo e gás natural é a exploração de uma atividade de natureza econômica cujo monopólio é detido pela União ${ }^{387}$. É, portanto, típico ato de gestão, em que, valendose da dicotomia com as devidas ressalvas já feitas, o Estado não exerce poder de império, mas atua de maneira semelhante a um particular, ou equiparado a ele.

Então, todas as questões referentes aos contratos de concessão seriam arbitráveis?

Há corrente no sentido de que as cláusulas essenciais do contrato de concessão (art. 43 da Lei n. 9.478/97) não poderiam ser apreciadas por meio de arbitragem, que estariam dentro de sua porção "indisponível”. Existe, por outro lado, corrente defendendo a ampla utilização de arbitragem nesses contratos, dada a sua previsão legal ${ }^{388}$. Para Joaquim de Paiva Muniz, a segunda interpretação não está correta porque, mesmo que haja previsão específica para utilização de arbitragem em determinado âmbito de atuação da Administração, esta deve ser lida em conjunto com a própria Lei de Arbitragem, que prevê que o instrumento só será utilizado no caso de direitos patrimoniais indisponíveis.

\footnotetext{
386 MUNIZ, Joaquim de Paiva. Os limites da arbitragem nos contratos de concessão de exploração e produção de petróleo e gás natural. Revista de Arbitragem e Mediação, São Paulo, Revista dos Tribunais, n. 2, p. 90-101, mai./ago. 2004, p. 98.

387 MUNIZ, Joaquim de Paiva. Os limites da arbitragem nos contratos de concessão de exploração e produção de petróleo e gás natural, cit., p. 96.

388 MUNIZ, Joaquim de Paiva. Os limites da arbitragem nos contratos de concessão de exploração e produção de petróleo e gás natural, cit., p. 97.
} 
Portanto, o desafio é identificar o que é e o que não é disponível dentro de um contrato de concessão ${ }^{389}$. O cumprimento ou não de uma cláusula regulamentar é questão que advém do poder de império do Estado, ou seja, este está limitando a forma como determinada atividade pode ser exercida. Assim, não pode o árbitro determinar, por exemplo, qual a natureza de uma corrente elétrica, pois isto está definido em regulamentação própria. Por outro lado, termos e condições de natureza econômicofinanceira e controvérsias de fato, como o cumprimento ou não de determinadas obrigações, são questões arbitráveis por este critério ${ }^{390}$.

Independentemente da correção da observação feita pelo autor, a discussão em torno dos limites da arbitragem no campo das concessões de exploração de recursos naturais nos mostra que as dicotomias traçadas no Capítulo 2 (interesse público primário/interesse público secundário; atos de gestão/atos de império) não são adequadas para avaliar a possibilidade ou não do uso de meios extrajudiciais, sendo que cada área regida pelo Direito Público contém especificidades que definem os limites do uso da arbitragem (legalmente limitada aos "interesses patrimoniais disponíveis") e, no caso do uso de meios consensuais, os limites do que deve pode ser negociado e o que é ponto inafastável.

f) Lei dos Transportes Aquaviário e Terrestre (Lei n. 9.432/97)

Lei dos Transportes Aquaviário e Terrestre (Lei n. 9.432/97) prevê a possibilidade de "conciliação" e "arbitragem" para as duas figuras contratuais previstas na lei, o contrato de concessão e o de permissão.

Art. 35. O contrato de concessão deverá refletir fielmente as condições do edital e da proposta vencedora e terá como cláusulas essenciais, ressalvado o disposto em legislação específica, as relativas a:

(...) XVI - regras sobre solução de controvérsias relacionadas com o contrato e sua execução, inclusive a conciliação e a arbitragem;

Art. 39. O contrato de permissão deverá refletir fielmente as condições do edital e da proposta vencedora e terá como cláusulas essenciais as relativas a:

(...) XI - regras sobre solução de controvérsias relacionadas com o contrato e sua execução, incluindo conciliação e arbitragem;

389 MUNIZ, Joaquim de Paiva. Os limites da arbitragem nos contratos de concessão de exploração e produção de petróleo e gás natural, cit., p. 97.

390 MUNIZ, Joaquim de Paiva. Os limites da arbitragem nos contratos de concessão de exploração e produção de petróleo e gás natural, cit., p. 97-98. 
g) Lei de Comercialização de Energia Elétrica (Lei n. 10.848/04)

A Lei de Comercialização de Energia Elétrica (Lei n. 10.848/04) prevê a arbitragem como forma de resolver conflitos entre os agentes integrantes da Câmara de Comercialização de Energia Elétrica (CCEE), possibilitando, ainda, que empresas públicas e sociedades de economia mista que façam parte da Câmara possam aderi à convenção de arbitragem:

Art. $4^{\circ} .(\ldots)$

$\S 5^{\circ}$ As regras para a resolução das eventuais divergências entre os agentes integrantes da CCEE serão estabelecidas na convenção de comercialização e em seu estatuto social, que deverão tratar do mecanismo e da convenção de arbitragem, nos termos da Lei no 9.307, de 23 de setembro de 1996.

$\S 6^{\circ}$ As empresas públicas e as sociedades de economia mista, suas subsidiárias ou controladas, titulares de concessão, permissão e autorização, ficam autorizadas a integrar a CCEE e a aderir ao mecanismo e à convenção de arbitragem previstos no $\S 5^{\circ}$ deste artigo.

h) Parcerias público-privadas (PPPs)

A parceria público-privada, enquanto figura típica, foi criada pela Lei n. 11.079/2004. Ainda que existam outras formas de parcerias entre entes públicos e entes privados, o regulamento desta lei e a denominação foram reservados para as figuras previstas em seu art. $1^{\circ}$. Maria Sylvia Zanella Di Pietro elaborou conceito a partir da norma do referido artigo, segundo a qual

“parceria público-privada é o contrato administrativo de concessão que tem por objeto (a) a execução de serviço público, precedida ou não de obra pública, remunerada mediante tarifa paga pelo usuário e contraprestação pecuniária do parceiro público, ou (b) a prestação de serviço de que a Administração Pública seja usuária direta ou indireta, com ou sem execução de obra e fornecimento de instalação de bens, mediante contraprestação do parceiro público"391.

Gustavo Justino de Oliveira situa a parceria público-privada no âmbito da administração paritária, o que relativiza a verticalização da relação entre Administração e particular bem como a força das cláusulas exorbitantes, pois nesse contexto haveria reciprocidade de obrigações assumidas por ambas as partes do contrato. Assim, haveria pontos convergentes no contrato (o sucesso do empreendimento) e pontos de divergência

${ }^{391}$ DI PIETRO, Maria Sylvia. Direito Administrativo, cit., p. 290. 
(a forma de divisão de lucros e assunção de riscos) ${ }^{392}$. O autor adota conceito mais amplo de parceria público-privado, desenvolvido por Corinne Namblard, que a conceitua como "parcerias entre entidades públicas e empresas e investidores do setor privado, com o objetivo de conceber, planificar, financiar, construir e operar projetos de infra-estrutura habitualmente prestados através de mecanismos tradicionais como os contratos públicos" $" 393$.

Por ser forma contratual ligada especialmente à prestação de serviços públicos, há forte defesa do uso da arbitragem e de outros mecanismos extrajudiciais, porque, tratandose de instrumento de cooperação entre ente público e particular, o seu sucesso depende do cumprimento do contrato por ambos os lados, sem o que não haverá a segurança do capital investido em projetos de interesse do Poder Público, de forma que se teme que a solução das controvérsias sobre o contrato fique sujeita às vicissitudes próprias do Poder Judiciário, como que devem ser neutralizadas, como a possibilidade de recursos procrastinatórios, gerando imprevisibilidade decorrente do desconhecimento dos mecanismos financeiros envolvidos ${ }^{394}$.

Sobre a previsão legal em si, a Lei Estadual n. 14.868/03 do Estado de Minas Gerais foi a primeira a instituir expressamente a arbitragem no âmbito das PPPs, prevendo inclusive balizas mais claras quanto à escolha de árbitros, a adoção de arbitragem institucional e o foro da Capital do Estado:

Art. 13. Os instrumentos de parceria público-privada previstos no art. 11 desta Lei poderão estabelecer mecanismos amigáveis de solução de divergências contratuais, inclusive por meio de arbitragem.

$\S 1^{\circ} \mathrm{Na}$ hipótese de arbitragem, os árbitros serão escolhidos dentre pessoas naturais de reconhecida idoneidade e conhecimento da matéria, devendo o procedimento ser realizado de conformidade com regras de arbitragem do órgão arbitral institucional ou entidade especializada.

$\S 2^{\circ}$ A arbitragem terá lugar na Capital do Estado, em cujo foro serão ajuizadas, se for o caso, as ações necessárias para assegurar a sua realização e a execução da sentença arbitral.

No plano nacional, a Lei de PPPs (Lei n. 11.079/04) também prevê a utilização de arbitragem:

392 OLIVEIRA, Gustavo Henrique Justino de. A arbitragem e as parcerias público-privadas. Revista Eletrônica de Direito Administrativo Econômico. Salvador, IDPB, n. 2, mai./jul. 2005, p. 3-5.

${ }^{393}$ NAMBLARD, Corinne. Para um enfoque pragmático de parceria público-privada. apud OLIVEIRA, Gustavo Henrique Justino de. A arbitragem e as parcerias público-privadas. Revista Eletrônica de Direito Administrativo Econômico. Salvador, IDPB, n. 2, mai./jul. 2005, p. 3-5.

${ }^{394}$ GLEBER, Eduardo. A solução de controvérsias em contratos de parceria público-privada, cit., p. 68-69. 
Art. 11. O instrumento convocatório conterá minuta do contrato, indicará expressamente a submissão da licitação às normas desta Lei e observará, no que couber, os $\S \S 3$ o e 40 do art. 15, os arts. 18, 19 e 21 da Lei no 8.987, de 13 de fevereiro de 1995, podendo ainda prever:

III - o emprego dos mecanismos privados de resolução de disputas, inclusive a arbitragem, a ser realizada no Brasil e em língua portuguesa, nos termos da Lei no 9.307, de 23 de setembro de 1996, para dirimir conflitos decorrentes ou relacionados ao contrato.

Antes de sua aprovação pelo Congresso Nacional, o dispositivo foi criticado por não conferir a segurança jurídica necessária no caso de necessidade de implementação da arbitragem, pois poderia prever maiores detalhes, a exemplo da lei estadual mineira, que evitassem impasses no momento da instauração da arbitragem, pela possível resistência da parte à formalização do compromisso ${ }^{395}$. De qualquer forma, há autorização geral para a adoção de "mecanismos privados", onde podemos situar também a conciliação e a mediação, ou, ainda, a figura dos dispute boards já descrita.

\subsubsection{2. "Arbitragem" e conciliação no âmbito das Agências Reguladoras}

Além da arbitragem regulada pela Lei n. 9.307/96, que é o equivalente jurisdicional apto a formar título executivo judicial, e que se desenvolve mediante os princípios do contraditório e da ampla defesa e todos os seus desdobramentos, existem, no âmbito dos conflitos envolvendo a administração pública, outros instrumentos com certo grau de consensualidade a que o legislador atribui o nome de "arbitragem".

Esses instrumentos se desenvolvem por um processo administrativo e sua decisão se sujeita a recurso administrativo em um primeiro momento e ampla revisão judicial em um segundo ${ }^{396}$, não sendo dotados de definitividade. Normalmente, são mecanismos que se prestam à composição não de conflitos entre a Administração Pública e o particular, mas sim entre particulares e aqueles que exercem atividade regulada.

Assim, na Lei das Telecomunicações (Lei n. 9.472/97), temos a previsão do artigo 19, inciso XVII, que dá competência à Agência Nacional de Telecomunicações "compor administrativamente conflitos de interesses entre prestadoras de serviço de telecomunicações".

\footnotetext{
395 Nesse sentido: GARCEZ, José Maria Rossani. O Estado, suas agências, as empresas públicas e as sociedades de que participa na arbitragem privada, cit., p. 113.

${ }^{396}$ MORAES, Luiza Rangel de. Arbitragem e agências reguladoras, cit., p. 83.
} 
A “arbitragem" interna da Anatel surgiu com o "Regulamento de Interconexão"397 (Resolução Anatel n. 40, de 1998), revogado posteriormente pela Resolução Anatel n. 410, de 2005, cuja atual redação é:

Art. 16. A prestadora que recebe o pedido de Interconexão deve oferecer alternativa compatível, quando houver indisponibilidade de meios ou facilidades no Ponto de Interconexão pleiteado.

(...)

$\S 3^{\circ}$ Não havendo acordo, o assunto deve ser objeto de arbitragem pela Anatel.

(...)

Anexo III

Da Arbitragem

Art. $1^{\circ}$ A submissão de qualquer questão à arbitragem não exime as prestadoras da obrigação de dar integral cumprimento a contratos de interconexão vigentes, nem permite a interrupção das atividades vinculadas a tais contratos.

Art. $2^{\circ}$ A arbitragem das condições de Interconexão é feita pela Comissão de Arbitragem composta por três membros nomeados pelo Presidente da Anatel e que se reúne sempre que a Anatel for provocada.

Parágrafo único. Cabe à Comissão a homologação de acordos de Interconexão.

De fato, o Regimento Interno da Anatel (Resolução n. 612, de 2013) prevê, em seu art. 93, que "[a]s prestadoras de serviços de telecomunicações poderão requerer à Anatel a instauração do Procedimento de Mediação, visando a solução consensual de questões relativas ao reconhecimento ou atribuição de direitos".

Contudo, vale ressaltar que a mera previsão não basta para a efetiva operação do instrumento e, mais que isso, para seu adequado funcionamento. Estudo de caso realizado em pesquisa na Universidade Federal Fluminense acompanhou procedimento de mediação instalado no âmbito da Anatel, envolvendo um problema de interconexão entre duas grandes empresas, a Embratel e a TCS, no qual a Embratel reclamava de condições técnicas e comerciais a serem aplicadas no compartilhamento de um ponto de transmissão. A autora Celia Passos relata que, no caso, a mediação foi infrutífera, e atribuiu o insucesso, dentre outros fatores, ao fato de ter sido conduzida por um superintendente, com muitas atribuições e sem treinamento para mediar conflitos, que acabou por conduzir a mediação de forma adversarial, de forma que os participantes manifestaram o desejo de continuar a negociação fora do âmbito da Anatel, o que, contudo, não ocorreu. A autora da pesquisa acentua a inexistência, no âmbito da agência, de um curso de capacitação do pessoal para

397 Interconexão, segundo o Regulamento, é "ligação de Redes de Telecomunicações funcionalmente compatíveis, de modo que os Usuários de serviços de uma das redes possam comunicar-se com Usuários de serviços de outra ou acessar serviços nela disponíveis" (art. $\left.3^{\circ}, \mathrm{V}\right)$. 
condução de mediações ${ }^{398}$. Essa questão da capacitação e preparo de condutores dos meios consensuais aparenta ser de bastante importância para o sucesso de um modelo consensual de solução de conflitos, como veremos em tópico adequado

No âmbito da Agência Nacional de Energia Elétrica (Aneel), a Lei n. 9.427/96 conferiu competência para "dirimir, no âmbito administrativo, as divergências entre concessionárias, permissionárias, autorizadas, produtores independentes e autoprodutores, bem como entre esses agentes e seus consumidores" (art. $3^{\circ}$, inciso V).

A previsão legal foi regulamentada no âmbito da Aneel pela Portaria do Ministério de Minas e Energia n. 349, de 1997, que institui pelo artigo 23 a Superintendência de Mediação Administrativa Setorial, com competência para "executar as atividades relacionadas aos processos de consulta aos agentes econômicos, a consumidores de energia elétrica e à sociedade e de atendimento às suas reclamações".

$\mathrm{Na}$ prática, o que se verifica é a criação de uma Ouvidoria pela mencionada Superintendência que recebe reclamações eletrônicas ${ }^{399}$ e se propõe a solucionar os problemas apresentados e proporcionar melhorias no relacionamento entre as prestadoras e os consumidores, bem como "[q]uando identifica casos semelhantes, a SMA procura, além de solucionar a questão pontual, encaminhar a correção das práticas e procedimentos que motivaram a reincidência do problema, com atuação pró-ativa, em benefício da coletividade". Referida Agência, contudo, faz questão de ressaltar em seu canal de comunicação com o consumidor que o encaminhamento à Ouvidoria não exclui a possibilidade de abertura de processo administrativo no âmbito da própria agência ou, ainda, de processo judicial ${ }^{400}$.

No âmbito da Agência Nacional de Petróleo (ANP), é conferida ampla competência para composição de conflitos, conforme previsão do art. 19 do Decreto n. 2.455/98:

Art. 19. A atuação da ANP, para a finalidade prevista no art. 20 da Lei $n^{\circ}$ 9.478, de 1997, será exercida, mediante conciliação ou arbitramento, de forma a:

I - dirimir as divergências entre os agentes econômicos e entre estes e os consumidores e usuários de bens e serviços da indústria do petróleo;

398 PASSOS, Celia Maria Oliveira. Prática da Mediação na Agência Nacional de Telecomunicações. Dissertação (mestrado em Direito e Sociologia) - Universidade Federal Fluminense (UFF), Rio de Janeiro, 2008, p. 159-165.

399 Por meio de formulário disponível em: http://www.aneel.gov.br/aplicacoes/fale_conosco/conect_formCPF.cfm>.

400 ANEEL. Orientação sobre a ouvidoria setorial da ANEEL. Disponível em: < http://www.aneel.gov.br/arquivos/PDF/Orientacoes_Ouvidoria_Setorial_ANEEL.pdf>. Acesso em: 17.10.2014. 
II - resolver conflitos decorrentes da ação de regulação, contratação e fiscalização no âmbito da indústria do petróleo e da distribuição e revenda de derivados de petróleo e álcool combustível;

III - prevenir a ocorrência de divergências;

IV - proferir a decisão final no campo administrativo, com força determinativa, em caso de não entendimento entre as partes envolvidas;

V - utilizar os casos mediados como subsídios para a regulamentação.

Parágrafo único. O Regimento Interno da ANP definirá os procedimentos administrativos para os processos de conciliação e de arbitramento.

Por fim, vale relatar a existência da Resolução Conjunta n. 1, das três agências reguladoras (Anatel, Aneel e ANP) prevendo resolução de conflitos de interesse entre os agentes, nas ações de compartilhamento de infraestrutura entre os três setores, serão resolvidos pelas agências na forma de Regulamento Conjunto n. 2, que prevê a instituição de uma Comissão de Resolução de Conflitos, de caráter permanente, constituída por dois membros de cada Agencia, com competência para mediar e arbitrar os conflitos surgidos em matéria de interpretação e aplicação dos regulamentos, no desenvolvimento das negociações de contratos de compartilhamento.

\subsubsection{Termos de compromisso (administrativos ou judiciais)}

As expressões "termo de compromisso" (TC) ou "termo de ajustamento de conduta" (TAC) são previstas em diversos diplomas legais e designam diferentes instrumentos com diferentes propósitos específicos. Em linhas gerais, o que há de comum entre as várias figuras é que: (i) são instrumentos consensuais de solução de conflitos; (ii) têm como objetivo a tutela de um interesse público ou metaindividual específico mediante adequação da conduta do interessado à lei ou assunção de obrigações; (iii) substituem ou a imposição administrativa de uma sanção (acordos substitutivos) ou a tutela do interesse por ação judicial.

Há uma grande quantidade de normas que criam meios consensuais de solução de conflitos entre a Administração e particulares, com autorização para sua utilização, ao menos em abstrato. Ao estudar cada previsão de forma mais detida, notamos que existem graus de generalidade diferentes, que conferem diferentes graus de detalhamento e podem, por hipótese, acabar influenciando a decisão pela adoção ou não do meio consensual, conferindo maior ou menor percepção de segurança jurídica ao Administrador.

A Lei de Ação Civil Pública (Lei n. 7.347/85) prevê em seu art. $5^{\circ}, \S 6^{\circ}$, a celebração de ajuste de conduta nos temas que podem ser objeto da ação pelos entes 
públicos legitimados à sua propositura. A lei disciplina a tutela de um grande espectro de interesses de natureza coletiva ou difusa, de forma que a abrangência do possível termo de ajuste de conduta é igualmente ampla. Segundo o art. $1^{\circ}$, os legitimados podem proteger, por meio da Ação Civil Pública, o meio ambiente, os direitos do consumidor, bens e direitos de valor artístico, histórico, turístico e paisagístico, interesses concernentes à ordem econômica, à ordem urbanística, à honra e dignidade de grupos raciais, étnicos ou religiosos, e ao patrimônio público e social (esses dois últimos incluídos recentemente, em 2014), além de "qualquer outro interesse difuso ou coletivo".

Registre-se a posição de Susana Henriques da Costa de que a moralidade administrativa e o patrimônio público não poderiam, a princípio, ser objeto de ação civil pública e, consequentemente, do termo de ajuste de conduta, pois são "interesses gerais", sendo o primeiro um princípio administrativo e o segundo um dos meios pelos quais o Estado atinge suas finalidades. Para a autora, a Constituição Federal abriu uma única exceção, qual seja a tutela do patrimônio público via ação civil pública pelo Ministério Público (art. 129, inciso III, da CF), mantendo-se de fora, contudo, a moralidade administrativa, que não contém previsão constitucional ${ }^{401}$.

Parte da questão, contudo, parece ter sido superada pela superveniência da Lei n. 13.004, de 24 de julho de 2014, que passou a prever expressamente a tutela do "patrimônio público e social" pela Ação Civil Pública, de forma que não há mais a limitação quanto ao objeto nem quanto aos legitimados para tutelar tais interesses por tal instrumento e, consequentemente, pelo termo de ajuste de conduta.

Note-se que, entre os entes públicos legitimados estão o Ministério Público, a Defensoria Pública, a União, os Estados e os Municípios (art. $5^{\circ}$ ), de forma que a Administração Pública pode participar do TAC tanto como ente que está tutelando o interesse público envolvido quanto ente que o está supostamente lesando, o que não é incomum.

Discute-se, por outro lado, se é possível que entes da administração pública indireta tomarem termo de compromisso de interessados. Segundo Susana Henriques da Costa, os entes da administração pública indireta poderiam tomar termo de compromisso somente se estivessem perseguindo o interesse público, assim entendido o interesse público "primário" (como, por exemplo, uma empresa pública prestadora de serviços públicos), e não

401 COSTA, Susana Henriques. O processo coletivo na tutela do patrimônio público e da moralidade administrativa. São Paulo: Quartier Latin, 2009, p. 157-158. 
enquanto exploradores de atividade econômica (como, por exemplo, uma empresa estatal de exploração de recursos naturais $)^{402}$.

Outro ponto importante é que não existe limitação quanto ao conteúdo a ser assumido pelo termo de compromisso, não obstante a literalidade da lei se refira ao "ajustamento de sua conduta às exigências legais, mediante cominações", aparentemente restringindo-o; entende-se que a obrigação assumida pode ser de qualquer natureza, de fazer ou não fazer, entregar coisa certa ou pagamento de quantia, dependendo o que o interesse metaindividual demanda para sua proteção ${ }^{403}$.

Além da ampla previsão da Lei n. 7.347/85, outras leis subsequentes que tratam de interesses difusos ou coletivos preveem a possibilidade de termo de ajuste de conduta, como é o caso do Estatuto da Criança e do Adolescente (Lei n. 8.069/90) que prevê, no art. 211, a possibilidade dos órgãos públicos legitimados tomarem compromisso do ajuste de conduta no âmbito da tutela de interesses coletivos ou difusos ligados à proteção da criança e do adolescente, mormente os listados no art. 208 do Estatuto.

Outro exemplo é a Lei n. 9.605/98, que trata da aplicação de sanções administrativas e criminais por condutas e atividades lesivas ao meio ambiente, e foi acrescida art. 79-A, que passou a prever a possibilidade de os órgãos do Sistema Nacional do Meio Ambiente celebrarem termo de compromisso com as pessoas físicas ou jurídicas responsáveis pelos estabelecimentos e atividades potencialmente poluidoras ${ }^{404}$.

$\mathrm{O}$ interessante é de notar que o $\S 1^{\circ}$ do artigo já delimitou $o$ que o órgão público poderá negociar, restringindo a "permitir que as pessoas físicas e jurídicas mencionadas no caput possam promover as necessárias correções de suas atividades, para o atendimento das exigências impostas pelas autoridades ambientais competentes", vedando qualquer medida que relativize a lei ambiental ou a proteção do meio ambiente em si.

A Lei n. 6.385/76, que criou a Comissão de Valores Mobiliários, foi alterada pela Lei n. 9.457/97, que incluiu os parágrafos $5^{\circ}$ a 12 ao art. 11, para prever a possibilidade de suspensão do processo administrativo sancionador mediante celebração de termo de compromisso. Os dispositivos foram regulamentados pela Deliberação CVM n. 390 de

402 COSTA, Susana Henriques da. Comentário ao art. $5^{\circ}$ da Lei de Ação Civil Pública. (coor.). Comentários à Lei de Ação Civil Pública e à Lei de Ação Popular. São Paulo: Quartier Latin, 2006, p. 427.

${ }^{403}$ COSTA, Susana Henriques da. Comentário ao art. $5^{\circ}$ da Lei de Ação Civil Pública, cit., p. 423.

${ }^{404}$ Em matéria ambiental, também há a previsão de termo de compromisso nos seguintes diplomas: Decreto n. 99.274/90 (art. 42) e Decreto n. 6.514/2008 (arts. 138 a 148). 
2001. Há nota de que, na prática, o instrumento só passou a ser utilizado após a regulamentação e a criação do Comitê do Termo de Compromisso ${ }^{405}$.

Os termos de compromisso celebrados com a CVM são tidos como "acordos substitutivos", por substituírem, através do ato consensual, o ato imperativo e unilateral da administração pública, qual seja a imposição de sanções administrativas. Note-se que a prerrogativa sancionadora é uma das mais importantes da Administração Pública e, não obstante, pode ser substituída por ato consensual (a já mencionada "concertação administrativa").

Segundo Juliana Bonacorsi de Palma, os acordos substitutivos têm como funcionalidade:

“(i) substituir a sanção administrativa ao final do processo administrativo, (ii) suspender o trâmite do processo administrativo sancionador com a celebração do acordo administrativo e, após cumprimento de seus termos, determinar a extinção do processo ou (iii) impedir a instauração de processo administrativo sancionador" 406 .

A CVM registra em seu sítio eletrônico 464 acordos firmados entre 1998 e 2014, com um aumento exponencial a partir de $2005^{407}$, quando editada a Deliberação n. 489. Os acordos devem prever (i) a cessação da prática de atividades ou atos considerados ilícitos, se for o caso; e (ii) a correção as irregularidades apontadas, inclusive indenizando os prejuízos causados ao mercado ou à $\mathrm{CVM}\left(\right.$ art. $\left.9^{\circ}\right)$. Ou seja, é uma forma de se atingir o mesmo interesse público que se atingiria com a imposição de sanção. A vantagem que é apontada na celebração consensual é que está tem uma maior adesão por parte do particular, por ter sido assumida voluntariamente, além de ser compromisso irreversível, não passível de ampla revisão judicial ${ }^{408}$.

No âmbito do Conselho Administrativo de Defesa Econômica (CADE), que tem como missão legal a prevenção de atos lesivos à livre concorrência no país e a fiscalização e punição de práticas ofensivas ao mercado, a Lei de Defesa da Concorrência (Lei n. 12.529/11) prevê, no art. $9^{\circ}$, inciso $\mathrm{V}$, e art. 85 a possibilidade de adoção de compromisso

\footnotetext{
${ }^{405}$ SOUZA, Luciane Moessa de. Resolução consensual de conflitos envolvendo o Poder Público, cit., p. $162-$ 169 , p. 163.

${ }^{406}$ PALMA, Juliana Bonacorsi de. Atuação administrativa consensual, cit., p. 192.

407 COMISSÃO DE VALORES IMOBILIÁRIOS. Termos de compromisso celebrados com a CVM Índice geral. Disponível em: < http://www.cvm.gov.br/port/inqueritos/Termos/TermosCompr.asp>. Acesso em: $14 / 12 / 2014$.

408 FADANELLI, Vinícius Krüger Chalub. Termo do compromisso em processo administrativo sancionador da Comissão de Valores Mobiliários. Dissertação (mestrado) - Faculdade de Direito da Universidade de São Paulo (USP), São Paulo, 2013, p. 76-77.
} 
de cessação de conduta lesiva à concorrência, em substituição à imposição de sanção e correção coercitiva de práticas.

A Lei n. 9.469/97, que permite a intervenção da Advocacia-Geral da União e dos dirigentes das empresas públicas federais para a realização de acordos e transações em juízo (art. $1^{\circ}$ ), com alteração dada pela Lei n. 12.249/2010, prevê, no art. $4^{\circ}$-A, a possibilidade de termo de ajustamento de conduta firmado pela Advocacia-Geral da União, no caso de prevenção ou extinção de litígios envolvendo interesse da União ou de suas autarquias e fundações, prevendo, ainda, o seu conteúdo mínimo:

Art. 4ํ-A. O termo de ajustamento de conduta, para prevenir ou terminar litígios, nas hipóteses que envolvam interesse público da União, suas autarquias e fundações, firmado pela Advocacia-Geral da União, deverá conter:

I - a descrição das obrigações assumidas;

II - o prazo e o modo para o cumprimento das obrigações;

III - a forma de fiscalização da sua observância;

IV - os fundamentos de fato e de direito; e

V - a previsão de multa ou de sanção administrativa, no caso de seu descumprimento.

Parágrafo único. A Advocacia-Geral da União poderá solicitar aos órgãos e entidades públicas federais manifestação sobre a viabilidade técnica, operacional e financeira das obrigações a serem assumidas em termo de ajustamento de conduta, cabendo ao Advogado-Geral da União a decisão final quanto à sua celebração.

A Lei de Diretrizes e Bases da Educação Nacional (Lei n. 9.394/96) permite ajuste de conduta na atividade de fiscalização das instituições de ensino superior, conforme o art. $46, \S 1^{\circ}$, e arts. 47 a 50 do Decreto n. 5.773/2006.

Relativamente à Consolidação das Leis do Trabalho (Decreto-Lei n. 5.452/43), alterada em 2001, foi acrescido o art. 627-A e alterado o art. 876 para prever a possibilidade de termo de compromisso ou ajuste de conduta em matéria de segurança do trabalho, cuja fiscalização compete ao Ministério do Trabalho, Indústria e Comércio (art. 626), o que foi regulamentado pelo Decreto n. 4.552/2002.

Também no âmbito das diversas agências reguladoras criadas a partir da segunda metade da década de 90, como forma de regulamentar atividades e serviços básicos para a infraestrutura e garantia de direitos básicos do cidadão, foi prevista a competência para, além dos mecanismos de "arbitragem" e mediação já descritos, a celebração de termos de ajustamento e algumas com expressa referência à conciliação e à arbitragem:

a) ANP - art. 20 da Lei n. 9.478/97 e Portaria ANP n. 69/2011, art. 54;

b) Agência Nacional de Transportes Terrestres (ANTT) - Resolução n. 442/2004, art. 11, inciso IV, e art. 18, inciso X; 
c) Agência Nacional de Transportes Aquaviários (Antaq) - Resolução n. 987/2008, art. 16;

d) Agência Nacional de Saúde (ANS) - Lei n. 9.656/98, art. 29, §1 e Lei n. 9.961/2000, art. $4^{\circ}$, inciso XXXIX;

e) Superintendência Nacional de Previdência Complementar (Previc) - Lei n. 12.154/2009, art. $2^{\circ}$, inciso VIII, e Instruções Previc n. 3 e 7/2010.

Na impossibilidade de verificar a efetiva implantação de cada um dos instrumentos consensuais acima apontados, o que demandaria pesquisa empírica que extrapolaria os limites deste trabalho, recorremos a fonte secundária, que nos relata que

"nem sempre a previsão normativa tem sido acompanhada da devida implementação de programas pelos entes públicos competentes. A pesquisa de campo que realizei no Brasil revela que são ótimos programas, que já produziram excelentes resultados, os do Cade, o da CVM e o da Aneel. Muitas dessas normas, infelizmente, ainda não "saíram do papel" $" 409$.

\subsubsection{Previsão de mecanismos consensuais e extrajudiciais de solução de} conflitos entre entes da Administração Pública

No âmbito da Advocacia-Geral da União, a conciliação em sede administrativa pode se dar entre entes da Administração Federal quando em conflito entre si, conforme a previsão da Portaria n. 1.281/2007 da Advocacia-Geral da União, que instituiu a Câmara de Conciliação e Arbitragem da Administração Federal (CCAF):

Art. $2^{\circ}$ Estabelecida controvérsia de natureza jurídica entre órgãos e entidades da Administração Federal, poderá ser solicitado seu deslinde por meio de conciliação a ser realizada:

I - pela Câmara de Conciliação e Arbitragem da Administração Federal - CCAF;

II - pelos Núcleos de Assessoramento Jurídico quando determinado pelo ConsultorGeral da União;

III - por outros órgãos da Advocacia-Geral da União quando determinado pelo Advogado-Geral da União.

Interessante notar que a Portaria fala em "atividades conciliatórias" e não em reunião ou sessão conciliatória (art. $7^{\circ}$, parágrafo único), sugerindo um efetivo procedimento consensual composto de vários atos em contraposição à visão estanque de uma única sessão. A cartilha divulgada pela Advocacia-Geral da União relata como pode

${ }^{409}$ SOUZA, Luciane Moessa de. Resolução consensual de conflitos envolvendo o Poder Público, cit., p. $162-$ 169, p. 165, nota de rodapé 4. 
ocorrer o procedimento: há a apresentação por parte do conciliador, que esclarecerá o procedimento conciliatório e a controvérsia. Em seguida, é dada a palavra às partes. Pode ser deliberado na reunião a assunção de tarefas, suas formas e prazos para cumprimento, bem como o agendamento de nova reunião, se for o caso ${ }^{410}$.

Ademais, a Portaria impõe a obrigação de a Escola da Advocacia-Geral da União promover cursos de capacitação para os conciliadores da Câmara. A competência da Câmara foi progressivamente ampliada para contemplar conciliação quando houver controvérsias entre: (i) a Administração Pública Federal e a Administração Pública dos Estados ou do Distrito Federal (Portaria AGU nº 1.099, de 28 de julho de 2008); (ii) entre a Administração Pública Federal e Municípios que fossem Capital de Estado ou que possuam mais de duzentos mil habitantes (Portaria AGU no 481, de 6 de abril de 2009); (iii) a Administração Pública Federal e qualquer município, sem limitação (Decreto $\mathrm{n}^{\circ}$ 7.392, de 13 de dezembro de 2010).

Antes da Portaria n. 1.281, de 2007, as conciliações entre a os órgãos da Administração Federal ocorriam ad hoc no âmbito da Consultoria-Geral da União, ou seja, este órgão determinava a criação de uma câmara de conciliação específica para cada caso.

Entre 2005 e 2007, o ementário de conciliação registra 14 conciliações, que atuaram sobre conflitos com os mais diversos objetos, desde execuções físcais da Procuradoria-Geral da Fazenda Nacional contra autarquias (como IBAMA e FUNAI) até reintegração de posse movida pelo Instituto Brasileiro do Meio Ambiente e dos Recursos Naturais contra população indígena, onde poderia haver interesse da Funai ${ }^{411}$.

A CCAF serviu de modelo, como veremos, para previsões contidas tanto no Código de Processo Civil recém-aprovado (PLS-SDC n. 166/2010) quanto no Projeto de Lei n. $7.169 / 2014$.

\subsubsection{Previsões legais para uso de meios consensuais no curso de processos} judiciais

${ }^{410}$ CÂMARA DE CONCILIAÇÃO E ARBITRAGEM DA ADMINISTRAÇÃO FEDERAL. Cartilha. 3. ed. Brasília: AGU, 2011, p. 17-18.

${ }^{411}$ ADVOCACIA-GERAL DA UNIÃO. Ementário da Conciliação na AGU/CGU - Câmaras ad hoc. Brasília: AGU, 2009. Disponível em: < http://www.agu.gov.br/page/content/detail/id_conteudo/170561>. Acesso em: 07.08.2014. 
$\mathrm{Na}$ seara judicial, encontramos diversas previsões genéricas aplicáveis aos entes públicos que estabelecem uma prática consensual genérica nos processos judiciais ou momentos processuais específicos para a tentativa de autocomposição.

No âmbito dos Juizados Especiais, encontramos tais previsões nas Leis $\mathrm{n}$. 10.259/2001 (Lei dos Juizados Especiais Federais) e 12.153/2009 (Lei dos Juizados Especiais da Fazenda Pública), em seus arts. 10, parágrafo único e $8^{\circ}$, respectivamente:

Art. 10. As partes poderão designar, por escrito, representantes para a causa, advogado ou não.

Parágrafo único. Os representantes judiciais da União, autarquias, fundações e empresas públicas federais, bem como os indicados na forma do caput, ficam autorizados a conciliar, transigir ou desistir, nos processos da competência dos Juizados Especiais Federais (grifo nosso).

Art. $8^{\circ}$. Os representantes judiciais dos réus presentes à audiência poderão conciliar, transigir ou desistir nos processos da competência dos Juizados Especiais, nos termos e nas hipóteses previstas na lei do respectivo ente da Federação (grifo nosso).

Ambas as previsões trazem uma falta de técnica denunciada por Luciane Moessa de Souza: como podem os representantes dos entes públicos ficarem autorizados a desistir nos juizados especiais se, nesse âmbito, apenas podem responder como réus? Uma possível solução seria entender a menção à desistência como autorização ao reconhecimento do direito, ou desistência da defesa ${ }^{412}$.

Por outro lado, notamos que a redação dos dispositivos não é suficiente para conferir autorização e competência ao advogado público isolado, efetivamente atuante no processo: na norma da Lei do Juizado Especial Federal, não fica claro se o advogado público atuante está autorizado a autonomamente decidir pela realização do acordo, sem autorização nos moldes da hierarquia do seu órgão. Na norma do Juizado Especial da Fazenda Pública, por outro lado, a autorização é dirigida especificamente ao "representante do réu presente à audiência". Contudo, essa possibilidade é condicionada às hipóteses indicadas em lei do ente federativo, o que faz sentido tendo em vista que uma lei federal não poderia regular especificamente a atuação em juízo dos advogados públicos de outro ente da federação. A efetiva utilização desses mecanismos consensuais em juízo depende de atribuição de competência ao advogado público ou, então, do vencimento das estruturas hierárquicas para obtenção da autorização do acordo.

${ }^{412}$ SOUZA, Luciane Moessa de. Meios consensuais de solução de conflitos envolvendo entes públicos, cit., p. 138. 
No procedimento comum, há previsão no Código de Processo Civil de momentos processuais específicos para realização de audiência de conciliação tanto no rito sumário (art. 277) quanto no ordinário (arts. 331 e 448), sem prejuízo da tentativa de conciliação a qualquer momento (art. 125, inciso IV).

O art. 331 não faz referência expressa aos entes públicos, e, ainda, traz a problemática restrição do uso da conciliação para "direitos que admitem transação", que já foi debatida no presente trabalho e, ainda que a devida interpretação não afaste a possibilidade de participação dos entes públicos, gera conclusões equivocadas sobre a questão.

$\mathrm{O}$ art. 277, por outro lado, deixa claro que a conciliação poderá contar com a participação da Fazenda Pública, ao prever que ela deverá ser citada para comparecimento à audiência de conciliação com o dobro da antecedência prevista no dispositivo ${ }^{413}$.

As normas em questão, ainda que não sejam capazes de conferir ao advogado público individual a segurança jurídica necessária para a utilização dos meios consensuais no processo em que atua, escancaram a possibilidade de seu uso naquele âmbito e abrem de forma mais clara a possibilidade de os entes públicos poderem acordar em juízo (afastando objeções antigas), além de estimular os entes federativos de nível estadual e municipal à edição de lei ou regulamento a respeito do tema.

Nesse tocante, ainda são limitações ao pleno desenvolvimento da prática consensual a ausência de autonomia funcional dos advogados públicos ${ }^{414}$, o baixo grau de regulação interna e o isolamento do profissional encarregado da representação em juízo ${ }^{415}$.

No mais, a previsão genérica, tal como posta nos dispositivos apontados, não apresenta balizas para o conteúdo do acordo a ser realizado em juízo. Se por um lado, como já visto, não é necessário que a lei estabeleça tais balizas, a previsão genérica não pode ser entendida como tabula rasa para a construção de qualquer acordo, uma autorização ampla e irrestrita. Ele deve, naturalmente, seguir outros condicionamentos, de que trataremos nos itens seguintes.

413 Art. 277. O juiz designará a audiência de conciliação a ser realizada no prazo de trinta dias, citando-se o réu com a antecedência mínima de dez dias e sob advertência prevista no $\S 2^{\circ}$ deste artigo, determinando o comparecimento das partes. Sendo ré a Fazenda Pública, os prazos contar-se-ão em dobro. (Redação dada pela Lei $\mathrm{n}^{\circ}$ 9.245, de 26.12.1995)

${ }^{414}$ SOUZA, Luciane Moessa de. Meios consensuais de solução de conflitos envolvendo entes públicos, cit., p. 138.

${ }^{415}$ GUEDES, Jefferson Carús. Transigibilidade de interesses públicos: prevenção e abreviação de demandas da Fazenda Pública, cit., p. 252. 
No âmbito federal, felizmente, a norma contida no art. 10, § único, da Lei n. 10.259/01 foi regulada pela Portaria AGU n. 109/2007 que, além de explicitar a competência dos advogados públicos "em exercício" no Juizado Especial Federal, traz balizas claras para a realização de acordos, havendo sua possibilidade quando houver erro administrativo, reconhecido pela autoridade competente ou pelo próprio advogado mediante motivação adequada e, ainda, quando não houver controvérsia fática ou jurídica, mediante parecer do órgão consultivo competente quanto à questão jurídica ${ }^{416}$.

Ainda a nível federal, há certa regulamentação da realização de acordos em juízo em casos que não os do Juizado Especial Federal. A Lei Complementar n. 73/93 (Lei Orgânica da Advocacia-Geral da União) prevê, em seu art. $4^{\circ}$, inciso VI, que é competência do Advogado-Geral da União transigir, acordar e firmar compromisso nas ações de interesse da União, podendo, ainda, delegar tal competência ao Procurador-Geral da União.

A Portaria AGU n. 7, de 2011, traz critérios para realização de acordos em ações regressivas acidentárias promovidas pela Procuradoria-Geral Federal contra empregadores quando o INSS arca com benefícios previdenciários decorrentes de acidentes de trabalho com culpa do empregador.

A possibilidade de delegação da competência para autorizar acordos ou transações em juízos aberta pela alteração à Lei n. 9.469/97 pela Lei n. 11.941 é vista como bastante salutar, sobretudo no âmbito federal, por facilitar a realização de acordos em uma estrutura que está espalhada por todo território nacional.

\footnotetext{
${ }^{416}$ Art. $3^{\circ} \mathrm{A}$ transação ou a não interposição ou desistência de recurso poderá ocorrer quando:

I - houver erro administrativo reconhecido pela autoridade competente ou, quando verificável pela simples análise das provas e dos documentos que instruem a ação, pelo advogado ou procurador que atua no feito, mediante motivação adequada; e

II - inexistir controvérsia quanto ao fato e ao direito aplicado.

$\S 1^{\circ} \mathrm{A}$ inexistência de controvérsia quanto ao fato deve ser verificável pelo advogado ou procurador que atua no feito pela simples análise das provas e dos documentos que instruem a ação, e a inexistência de controvérsia quanto ao direito aplicado deve ser reconhecida pelo órgão consultivo competente, mediante motivação adequada em qualquer das situações.

$\S 2^{\circ}$ Os valores envolvidos nas conciliações e transações não poderão exceder ao teto previsto no art. $3^{\circ}, \S 2^{\circ}$, da Lei n ${ }^{\circ} 10.259$, de 12 de julho de 2001, observado o disposto no art. 260 do Código de Processo Civil.

$\S 3^{\circ}$ Não serão objeto de acordo:

I - as hipóteses em que se discute penalidade aplicada a servidor;

II - os casos de dano moral, salvo se o agente causador do dano for entidade credenciada, contratada ou delegada de órgão de Administração Pública Federal e assuma, em juízo, a responsabilidade pelo pagamento acordado; e

III - o litígio que estiver fundado exclusivamente em matéria de direito e houver a respeito enunciado da Súmula da AGU, parecer aprovado na forma do art. 40 da Lei Complementar 73, de 1993 ou orientação interna adotada pelo Advogado-Geral da União contrários à pretensão.
} 
A delegação de fato foi operada para alguns órgãos, e interessa-nos sobretudo a delegação feita à Procuradoria-Geral da União, braço da AGU, responsável pela representação judicial da União, e à Procuradoria-Geral Federal, através da Portaria 990 de 16 de julho de 2009, que, delegou a competência para "autorizar a celebração de acordos ou transações" (art. $2^{\circ}$, caput) e previu, ainda, a possibilidade de subdelegação dessa competência $\left(\operatorname{art} .2^{\circ}, \S 2^{\circ}\right)$.

A Ordem de Serviço da PGU n. 13 de 2009, por sua vez, operando essa subdelegação em organização bastante interessante, dividiu os acordos em faixas de valor, permitindo que os advogados da união que atuem singularmente nos casos possam realizar transações e acordos em casos de até sessenta salários mínimos. Para valores superiores, autorizações de hierárquicos superiores são necessárias ${ }^{417}$.

No âmbito da PGF, também a Portaria n. 915, de 16 de setembro de 2009 opera a subdelegação da realização de acordo ou transação de acordo com a faixa de valores envolvidos:

\footnotetext{
Art. $1^{\circ}$ Os órgãos de execução da Procuradoria-Geral Federal ficam autorizados a realizar acordos ou transações, em juízo, para terminar o litígio, nas causas de valor até $\mathrm{R} \$ 1.000 .000,00$ (um milhão de reais), observados os seguintes limites de alçada: I - até 60 (sessenta) salários mínimos, pelos Procuradores Federais que atuam diretamente na causa;

II - até $\mathrm{R} \$ 100.000,00$ (cem mil reais), mediante prévia e expressa autorização dos Procuradores Seccionais e dos Chefes de Escritório de Representação;

III - até $\mathrm{R} \$ 500.000,00$ (quinhentos mil reais), mediante prévia e expressa autorização dos Procuradores-Chefes das Procuradorias Federais nos Estados;

IV - até $\mathrm{R} \$ 1.000 .000,00$ (um milhão de reais), mediante prévia e expressa autorização dos Procuradores Regionais Federais.
}

\subsubsection{Perspectivas normativas: Projeto de Lei sobre mediação e Poder Público (PLC n. 7.169/2014) ${ }^{418}$ e Novo Código de Processo Civil (PLS-PCD n.}

${ }^{417}$ Conforme notícia divulgada no site da AGU: "As conciliações podem ser realizadas em ações de até $\mathrm{R} \$$ 500 mil que tratam de créditos e débitos da União, mas devem ser observados limites impostos aos advogados da União. Aqueles advogados que atuam diretamente no processo podem fechar acordo de até 60 salários. Quando o valor chegar até R \$ 100 mil é necessária autorização dos Procuradores Seccionais ou dos Chefes dos Escritórios de Representação da PGU. Já quando for de até 500 mil, a permissão deve ser dada pelos Procuradores Regionais ou pelos Chefes das Procuradorias da União nos estados. Nos casos em que o valor do acordo ultrapassar R\$ 500 mil, ele deverá ser liberado exclusivamente pelo Procurador-Geral da União, Ministro de Estado, ou pelo titular da Secretaria da Presidência da República, da área pertinente ao assunto" (Disponível em: < http://www.agu.gov.br/page/content/detail/id_conteudo/102053 >. Acesso em 10.10.2014.

${ }^{418}$ O Projeto de Lei no Senado n. 517/2011 teve seu texto final aprovado na Comissão de Constituição e Justiça do Senado em fevereiro de 2014 e encaminhado para a Câmara no mesmo mês. O presente tópico é desenvolvido com base no segundo parecer emitido pela Comissão de Constituição e Justiça da Câmara em 
O Projeto de Lei da Câmara dos Deputados n. 7.169/2014, originalmente Projeto de Lei do Senado n. 517/2011, apresentado pelo Senador Ricardo Ferraço, é hoje tido como o principal projeto que objetiva estabelecer um marco legal para a mediação entre particulares e composição consensual de conflitos no âmbito da Administração Pública. A versão do projeto aprovada na Comissão de Constituição e Justiça (CCJ) foi, na verdade, um substitutivo derivado de três diferentes projetos de Lei: 517/2011, 405/2013 e 434/2013, e continha, nesta versão, seis artigos versando sobre composição de conflitos envolvendo entes de Administração Pública em geral (arts. 30 e 31) e mais seis dispositivos versando sobre a composição de conflitos envolvendo a administração federal especificamente (arts. 32 a 37).

Na versão aprovada pela Comissão de Constituição e Justiça da Câmara dos Deputados, a abrangência da disciplina da matéria foi basicamente mantida, tanto em relação à Administração Pública em geral (arts. 33 a 35) quanto em relação à administração federal (arts. 36 a 41).

O Projeto de Lei merece ser comentado, inclusive para fins desse trabalho, não apenas pelo seu avanço na matéria, por se relacionar com alguns conceitos desenvolvidos e algumas limitações aos meios consensuais, constituindo material que suscita interessantes raciocínios sobre o tema.

O primeiro instrumento mencionado pelo Projeto é o da "câmara de prevenção e resolução administrativa de conflitos", nos seguintes termos:

Art. 33. A União, os Estados, o Distrito Federal e os Municípios poderão criar câmaras de prevenção e resolução administrativa de conflitos, no âmbito dos respectivos órgãos da Advocacia Pública, onde houver, com competência para:

I - dirimir conflitos entre órgãos e entidades da Administração Pública;

II - avaliar a admissibilidade dos pedidos de resolução de conflitos, por meio de composição, no caso de controvérsia entre particular e pessoa jurídica de direito público;

III - promover, quando couber a celebração de termo de ajustamento de conduta.

O dispositivo contido no Projeto é refletido integralmente no artigo 175 recémaprovado Código de Processo Civil (PLS-SDC n. 166/2010), com a diferença de que o

junho de 2014 e no respectivo substitutivo apresentados em 17.12.2014. O Projeto, na Câmara, ganhou o número 7169/2014. AA última consulta foi realizada em 21.12.2014, nos site da Câmara dos Deputados: 〈http://www.camara.gov.br/proposicoesWeb/fichadetramitacao?idProposicao=606627> Acesso em: 21.12 .2014$. 
verbo "criar" é conjugado no imperativo ("A União, os Estados, o Distrito Federal e os Municípios criarão...”). Ou seja, havendo sanção presidencial sem veto do dispositivo, ele já estará pronto para entrar em vigência. O diploma, contudo, não traz outras previsões significativas sobre o tema.

As previsões em questão propõem uma centralização da composição extrajudicial de conflitos que envolvem a Administração Pública, abrigando, em sua competência, (i) a composição de conflitos entre os entes da própria administração, a exemplo da Câmara de Conciliação e Arbitragem da Administração Federal; (ii) o "pedido de resolução de conflitos" e (iii) a celebração de TACs. Essa centralização pode ser positiva, pois permite uma maior homogeneidade no tratamento consensual de conflitos, uma equipe que pode ser treinada e capacitada especificamente para tais práticas, com um domínio maior dos conceitos envolvidos e mais clareza sobre os limites da composição consensual, além de um alívio aos advogados público que atuam individualmente nas causas judiciais ou a quem foi submetida a questão ainda não judicializada que, além de não precisar decidir individualmente, teria um órgão específico a quem submeter tais questões e não um superior hierárquica com numerosas outras atribuições.

Apesar de avançar pouco em termos de implementação de tais práticas consensuais, que já poderiam ser adotadas independente dessa previsão legal como já visto nesse item, além de depender de regulamento próprio de cada ente federado e, portanto, de sua respectiva vontade política $\left(\S 1^{\circ}\right.$, art. 33$)$, o dispositivo tem o mérito de propor um modelo que pode orientar estados e municípios na implementação de meios consensuais.

Quanto às hipóteses de utilização em si, uma novidade pode ser vislumbrada na competência para analisar a admissibilidade de "pedido de resolução de conflitos, por meio de composição". Algumas observações podem ser feitas sobre a previsão: para sua maior efetividade, o inciso II deveria ser explícito em permitir também o encaminhamento de pedidos de resolução de conflitos por “composição" pela própria Administração à Câmara. A falta de clareza, contudo, não impede que a regulamentação inclua como competência da Câmara tal atribuição.

Outro ponto é a referência a "resolução de conflitos por composição", o que soa redundante; afinal, resolução e composição têm praticamente o mesmo significado quando tratamos de conflito, havendo apenas uma diferença valorativa do ato, como já esclarecido no item 3.1.1 deste trabalho. Se o projeto queria se referir à autocomposição, poderia ter sido mais técnico neste ponto. Por outro lado, se quisesse abranger a admissibilidade de todas as formas de composição, poderia prever a "autocomposição" e "hetercomposição 
extrajudicial", o que permitiria que a câmara tivesse também a competência para, além de avaliar a possibilidade de dirimir o conflito por acordo, a possibilidade de submetê-lo a arbitragem.

Outras especificidades tratadas pelo dispositivo são: (i) a facultatividade da submissão do conflito às câmaras e a limitação aos casos previstos por cada ente federado $\left(\S 2^{\circ}\right)$; (ii) a possibilidade de tornar o acordo firmado na Câmara título executivo extrajudicial $\left(\$ 3^{\circ}\right)$; (iii) a exclusão da competência das Câmaras nas controvérsias que somente possam ser resolvidas por atos ou concessão de direitos sujeitos a autorização do Poder Legislativo $\left(\S^{\circ}\right)$; (iv) o esclarecimento de que é possível submeter, a despeito do previsto no $\$ 4^{\circ}$, as controvérsias decorrentes das discussões sobre equilíbrio econômicofinanceiro dos contratos celebrados pela Administração Pública com particulares $\left(\S 5^{\circ}\right)$.

$\mathrm{O}$ art. 34 do projeto prevê que, enquanto não são criadas as Câmaras de Mediação especificamente determinadas, os conflitos serão trabalhados na forma da mediação judicial, cabendo ainda aos órgãos públicos (Advocacia Pública da União, Estados, Distrito Federal e Municípios) instaurarem a mediação coletiva que tenha como objeto de conflito a prestação de serviços públicos.

No art. 35, o projeto trata melhor da instauração de um "procedimento administrativo para a resolução consensual do conflito”, que parece ser possível tanto no âmbito da câmara mencionada no artigo anterior quanto fora dele:

\footnotetext{
Art. 35. A instauração de procedimento administrativo para a resolução consensual de conflito no âmbito da Administração Pública suspende a prescrição.

$\S 1^{\circ}$ Considera-se instaurado o procedimento quando o órgão ou entidade pública emitir juízo de admissibilidade, retroagindo a suspensão da prescrição à data de formalização do pedido de resolução consensual do conflito.

$\S 2^{\circ}$ Em se tratando de matéria tributária, a suspensão da prescrição deverá observar o disposto na Lei n ${ }^{\circ}$ 5.172, de 25 de outubro de 1996 (Código Tributário Nacional).
}

A segunda parte do projeto de lei no tocante à resolução de conflitos envolvendo a Administração Pública trata especificamente da Administração Pública Federal. A primeira previsão diz respeito à "transação por adesão", que designa uma forma de resolução de conflitos repetitivos, que têm por base a mesma discussão jurídica e, de um dos lados, o mesmo ente público.

Art. 36. A solução de controvérsias jurídicas que envolvam a Administração Pública Federal direta, suas autarquias e fundações poderão ser objeto de transação por adesão, com fundamento em:

I - autorização do Advogado-Geral da União, com base na jurisprudência pacífica do Supremo Tribunal Federal ou de tribunais superiores; ou

II - parecer do Advogado-Geral da União, aprovado pelo Presidente da República. 
$\S 1^{\circ}$ Os requisitos e as condições da transação por adesão serão definidos em resolução administrativa própria.

$\S 2^{\circ}$ Ao fazer o pedido de adesão, o interessado deverá juntar prova de atendimento aos requisitos e às condições estabelecidos na resolução administrativa.

$\S 3^{\circ}$ A resolução administrativa terá efeitos gerais e será aplicada aos casos idênticos, tempestivamente habilitados mediante pedido de adesão, ainda que solucione apenas parte da controvérsia.

$\S 4^{\circ} \mathrm{A}$ adesão implicará renúncia do interessado ao direito sobre o qual se fundamenta a ação ou o recurso, eventualmente pendentes, de natureza administrativa ou judicial, no que tange aos pontos compreendidos pelo objeto da resolução administrativa.

$\S 5^{\circ} \mathrm{Se}$ o interessado for parte em processo judicial inaugurado por ação coletiva, a renúncia ao direito sobre o qual se fundamenta a ação deverá ser expressa, mediante petição dirigida ao juiz da causa.

$\S 6^{\circ}$ A formalização de resolução administrativa destinada à transação por adesão não implica na renúncia tácita à prescrição, nem sua interrupção ou suspensão.

Algo semelhante foi praticado pela Caixa Econômica Federal, inclusive, para prevenir e extinguir demandas relativas aos planos econômicos implantados entre 1987 e 1992, que acarretaram correção diferenciada aos ativos financeiros de poupadores, demandas essas que inundaram o Poder Judiciário nas duas últimas décadas. No caso, os termos da transação foram disciplinados pela Lei Complementar n. 110/2001 especificamente para as defasagens ocorridas nas contas vinculadas ao FGTS. Os termos de transação previam expressamente a concessão de um percentual de desconto por parte do titular da conta (art. $6^{\circ}$ da LC n. 110/2001), que era progressivo de acordo com o valor que resultasse da aplicação da correção.

A experiência dos termos de transação da Caixa Econômica Federal acarretou uma rejudicialização da questão: muitos desses termos foram questionados judicialmente, tanto em razão da constitucionalidade da prática em si, quanto da falta de acompanhamento de $\operatorname{advogado}^{419}$, quanto em relação a situações específicas em que os poupadores diziam não terem sido devidamente informados das consequências da assinatura dos termos, quando existente sentença transitada em julgado ${ }^{420}$.

A questão acabou sendo levada ao Supremo Tribunal Federal e gerou a Súmula Vinculante n. 1, que validou a constitucionalidade da prática, asseverando que "ofende a garantia constitucional do ato jurídico perfeito a decisão que, sem ponderar as circunstancias do caso concreto, desconsidera a validez e a eficácia de acordo constante de termo de adesão instituído pela Lei Complementar n. 110/2001".

${ }^{419}$ Cf. BRASIL. Superior Tribunal de Justiça. Agravo Regimental no Recurso Especial n. 888763. Órgão Julgador: Primeira Turma. Relator: Ministros Francisco Falcão. J. em: 27/03/2007. DJ em: 260/04/2007.

${ }^{420}$ Cf. BRASIL Superior Tribunal de Justiça. Agravo Regimental no Recurso Especial n. 1123817-BA. Órgão Julgador: Segunda Turma. Relator: Min. Humberto Martins. J. em: 03/12/2009. DJe em: 16/12/2009. 
Contudo, a experiência da CEF demonstra a necessidade de cautelas no uso desse instrumento, incluindo uma atenção especial ao particular vulnerável informacional ${ }^{421}$, bem como a amplo conhecimento da consequência do ato de transação e o cuidado com a existência ou não de sentenças transitadas em julgado.

Outra questão que se coloca em relação à prática: seria verdadeiramente um meio consensual de solução de conflitos, na acepção adotada pelo presente trabalho? Ou apenas uma forma de gerenciamento extrajudicial de controvérsias?

A composição do resultado é, de fato, bilateral, e depende da coincidência da vontade do particular em aceitar ou "aderir" à proposta formulada pela Administração Pública. Por outro lado, o particular, isoladamente considerado, não influi em nada na formulação ou convencimento da proposta, limitando-se à comprovação do preenchimento dos requisitos previstos na resolução administrativa.

Como dito por um procurador do Município, em uma das entrevistas realizadas no bojo desta pesquisa, "quando há regulamento geral, deixa de ser conciliação e se torna direito reconhecido pela Administração". Contudo, o fato de ser um ato de reconhecimento de direitos não afasta o caráter consensual, pois ainda fica dependente do encontro de vontades.

$\mathrm{Na}$ verdade, a prática não se distancia muito de uma proposta de acordo feita pela Administração Pública em casos individuais cuja matéria envolve forte vinculação em lei (como benefícios previdenciários), de forma que há pouca discricionariedade do administrador, como veremos a seguir. Contudo, o fato de haver composição bilateral, pois não vincula o particular àquela solução sem a participação da sua vontade, permite enquadrar a "transação por adesão".

No mais, o uso da palavra "transação" aponta para o fato de que essa prática envolve a composição em que há "concessões recíprocas", havendo aí a ideia de que, mediante tal prática, a Administração poderia abrir mão de algum crédito, assim como o particular poderia optar por receber menos do que sua interpretação leva a concluir que tem direito.

Ademais, o instrumento parece ser adequado a questões que envolvam um alto grau de homogeneidade e de identidade, o que nem sempre é fácil de ser identificado.

\footnotetext{
${ }^{421}$ Fernanda Tartuce aponta a desinformação pessoal como um dos fatores indicadores de vulnerabilidade, que, na condução do processo judicial, legitimam a condução diferenciada, com medidas para a compensação dessa falta de informação (Cf. TARTUCE, Fernanda. Igualdade e vulnerabilidade no processo civil. Rio de Janeiro, Forense: 2012, p. 197).
} 
Por fim, o art. 37 do projeto em discussão prevê a competência da Advocacia-Geral da União para mediar conflitos entre entes da Administração Pública Federal e do Advogado-Geral da União para arbitrá-las, “observados os procedimentos previstos em ato do Advogado-Geral da União". O art. 38, por sua vez, faculta "aos Estados, ao Distrito Federal e aos Municípios, suas autarquias e fundações públicas, bem como às empresas públicas e sociedades de economia mista federais, submeter seus litígios com órgãos ou entidades da Administração Pública Federal à Advocacia-Geral da União, para fins de composição extrajudicial do conflito".

Os dispositivos trazem, na verdade, a experiência da Câmara de Conciliação e Arbitragem da Administração Federal (CCAF) para o nível legal ${ }^{422}$, explicitando competências da Advocacia-Geral da União e do Advogado-Geral da União já exercidas e delegadas no Ato Regimental n. 5/2007, mas que antes tinham eram lidas implicitamente em competências mais genéricas (quais sejam as previstas nos arts. $4^{\circ}$, incisos I e XIV, e 45 da Lei Complementar $n^{\circ} 73$, de 10/ 1993).

O projeto ainda toca em alguns pontos sensíveis quando o assunto é a solução consensual no âmbito da Administração Pública: prevê o art. $\$ 4^{\circ}$ do art. 37, que "se a matéria objeto do litígio esteja sendo discutida em ação de improbidade administrativa ou sobre ela haja decisão do Tribunal de Contas da União, a conciliação de que trata o caput dependerá da anuência expressa do juiz da causa ou do Ministro relator”.

Pode-se cogitar, no caso de aprovação deste projeto, de eventual conflito entre esta previsão e a previsão do art. $17, \S 1^{\circ}$, da Lei de Improbidade Administrativa (Lei n. 8.429/92), que veda o acordo nas ações nela baseadas. Contudo, é importante lembrar que as sanções previstas na Lei de Improbidade direcionam-se às pessoas físicas que ocupam cargos e funções, enquanto a composição no âmbito da Advocacia-Geral da União se dá entre "entidades de direito público", de forma que se poderia sustentar que a composição poderia ser feita na forma do dispositivo entre as pessoas jurídicas, sem prejuízo da aplicação de sanção às pessoas físicas envolvidas.

Por fim, na última versão que foi consolidada após o segundo relatório da Comissão de Constituição e Justiça, foram incluídas previsões nas disposições finais (art. 45 do Projeto) com propostas de modificações à Lei 9.469/97, com o objetivo de conferir maior

422 Cf. OLIVEIRA, Gustavo Justino de; SCHWARTSMANN, Guilherme Batista. Mediação e Administração Pública no Brasil: análise do Projeto de Lei n. 517/2011, p. 6. Disponível em: <http://www.justinodeoliveira.com.br/wp-content/uploads/2014/05/MEDIAÇÃO-E-ADMINISTRAÇÃOPÚBLICA-NO-BRASIL_2014.05.pdf>. Acesso em: 10.09.2014. 
dinamicidade à atuação consensual da Advocacia-Geral da União e da Procuradoria-Geral da União e das empresas públicas federais, através de normas da criação de novos instrumentos (como câmaras para análise e formulação de propostas de acordo ${ }^{423}$ ) e novas regras de competência (como a competência colegiada para firmar acordos no âmbito das empresas públicas federais ${ }^{424}$ ).

De toda forma, a expressa inserção de previsões sobre Administração Pública e resolução de conflitos vem sendo vista como um avanço no campo, ainda que insuficiente de, por si só, implementar as práticas consensuais, mas que, como anotado por Gustavo Justino de Oliveira e Guilherme Batista Schwartsmann tem o potencial para "numa perspectiva de prazo maior, condicionar a prática administrativa à composição amigável e à busca de consenso", reduzindo-se o tempo gasto pelas procuradorias com a gestão de processos judiciais e diminuindo-se os gastos administrativos ${ }^{425}$.

\subsection{Vinculação às prescrições legais}

Em mediação de conflitos, costuma-se apontar como uma das vantagens em relação à solução adjudicatória estatal a liberdade de escolha das partes quanto ao método, além do poder de decisão em relação ao conteúdo que querem ou não dar à composição de seu conflito. A liberdade individual é princípio da mediação que impede interferências de qualquer natureza $^{426}$.

Isso não significa que um processo de mediação poderá alcançar resultados ilícitos. Na prática corrente da mediação, diz-se que o controle de legalidade, ou melhor, o controle de eventuais ilegalidades, é realizado após o término do processo, como condição de validação da conduta dos sujeitos. Porém, não é a legalidade que direciona os valores a serem perseguidos durante a mediação, mas sim a pauta valorativa e os critérios

\footnotetext{
423 Art. 45. Os artigos $1^{\circ}$ e $2^{\circ}$ da Lei $n^{\circ} 9.469$, de 10 de julho de 1997 , passam a vigorar com a seguinte redação:

$\S 1^{\circ}$ Poderão ser criadas câmaras especializadas, compostas por servidores públicos ou empregados públicos efetivos, com o objetivo de analisar e formular propostas de acordos ou transações.

${ }^{424}$ Art. $2^{\circ}$ O Procurador-Geral da União, o Procurador-Geral Federal, o Procurador-Geral do Banco Central do Brasil e os dirigentes das empresas públicas federais mencionadas no caput do art. $1^{\circ}$, poderão autorizar, diretamente ou mediante delegação, a realização de acordos para prevenir ou terminar, judicial ou extrajudicialmente, litígio que envolver valores inferiores aos fixados em regulamento.

$\S 1^{\mathrm{o}}$ No caso das empresas públicas federais, a delegação é restrita a órgão colegiado formalmente constituído, composto por pelo menos 1 (um) dirigente estatutário.

425 Cf. OLIVEIRA, Gustavo Justino de; SCHWARTSMANN, Guilherme Batista. Mediação e Administração Pública no Brasil, cit.

${ }^{426}$ TARTUCE, Fernanda. Mediação nos conflitos civis, cit., p. 211-212.
} 
estabelecidos pelas próprias partes, residindo aí uma diferença relevante entre a mediação e a jurisdição estatal $^{427}$.

Contudo, essas observações bem servem ao particular, dotado de liberdade e que está vinculado negativamente à lei, ou seja, está apto a fazer tudo o que ela não proíba.

Em relação à Administração, prevalece a ideia de que ela está vinculada positivamente à lei, de forma que só pode fazer aquilo que a lei permitir. Por outro lado, já demonstramos no Capítulo 2 que uma compreensão revisitada da legalidade nos leva a concluir pela vinculação da Administração a termos mais amplos do que a simples legalidade estrita. Mas como isso interfere na composição consensual?

Primeiramente, deve ser estabelecido que, para qualquer negociação envolvendo a Administração Pública, o critério de composição deve ser a lei. A Administração não pode se furtar à legalidade e escolher outras bases sobre as quais irá negociar e compor conflitos.

Tomando a arbitragem por aproximação: o art. $2^{\circ}$ da Lei n. 9.307/96 permite que as partes escolham se os árbitros decidirão de acordo com o direito ou de acordo com o critério da equidade. $\mathrm{O} \S 1^{\circ}$ do referido artigo deixa ao livre arbítrio das partes a escolha de quais regras de direito serão aplicadas, podendo optar, inclusive, por uma lei estrangeira. O $\S 2^{\circ}$, por sua vez, permite a adoção dos critérios de princípios gerais de direito, usos e costumes e regras internacionais de comércio (lex mercatoria) ${ }^{428}$.

No entanto, defende-se, mesmo entre os autores mais afeitos à consensualidade, que na arbitragem envolvendo a Administração Pública jamais poderá ser admitido um pacto que preveja preferência ou opção por critérios alternativos ao critério do direito. Como afirma Justino de Oliveira, "os contratos administrativos regem-se pela legislação especial que os disciplina, não podendo haver decisões tomadas com base na equidade, por exemplo, ou quaisquer outros critérios previstos no art. $2^{\circ}$ da LA (além do critério do direito), o que afrontaria o art. 37 da CF" ${ }^{\prime 29}$.

No âmbito dos meios consensuais, muitas previsões de instrumentos de consenso preveem expressamente o critério da legalidade como base para celebração dos acordos. $\mathrm{O}$ próprio termo de ajuste de compromisso é firmado com a finalidade de "ajustamento de sua conduta às exigências legais, mediante cominações, que terá eficácia de título executivo extrajudicial" (art. $5^{\circ}, \S 6^{\circ}$ )". Também no âmbito da CVM, como mais um

427 FREITAS JR., Antonio Rodrigues. Sobre a relevância de uma noção precisa de conflito. Revista do Advogado. São Paulo, AASP, n. 123, p. 11-23, ago./2014, p. 17.

${ }^{428}$ Cf. CARMONA, Carlos Alberto. Arbitragem e processo. 2. ed. São Paulo: Atlas, 2006, p. 75-76.

${ }^{429}$ OLIVEIRA, Gustavo Henrique Justino de. A arbitragem e as parcerias público-privadas, cit., p. 24. 
exemplo, o termo deve ser firmado para "cessar a prática de atividades ou atos considerados ilícitos" e "corrigir as irregularidades apontadas, inclusive indenizando os prejuízos causados ao mercado ou à CVM" (art. $7^{\circ}$, da Deliberação CVM n. 390/2001), ou seja, dispõe, da mesma forma, sobre a adequação da conduta à lei.

Registram-se posições no sentido de que o respeito aos parâmetros legais existentes na matéria envolta na negociação é, inevitavelmente, um dos critérios a balizar a celebração de qualquer acordo ${ }^{430}$.

Isso estatuído, resta a pergunta do alcance de tal consideração: em que grau está a Administração Pública adstrita à legalidade, ao celebrar um acordo? Podemos falar, logo de início, em uma vinculação positiva, ou seja, a Administração somente poderia acordar aquilo que a lei expressamente a autoriza?

Nesse aspecto, são pertinentes as observações de Luciana Moessa de Souza, para quem a vinculação à legalidade não obsta o uso dos meios consensuais, porque há múltiplas interpretações para cada norma, além de nossa lei ostentar lacunas e contradições na ordem jurídica, nem todas solucionáveis pelos critérios clássicos ${ }^{431}$. Isso quer dizer que as normas jurídicas normalmente comportam mais de uma possível interpretação, e o fato de a Administração ostentar, inicialmente, uma posição a respeito de determinado assunto, não impede a reformulação de seu entendimento para fins de acordo.

A seguir, trataremos algumas situações em que a Administração Pública pode realizar acordos sem prejuízo da legalidade.

\subsubsection{O acatamento da orientação jurisprudencial}

O fato de a lei comportar, muitas vezes, mais de uma interpretação justifica, por exemplo, a defesa de que a Administração Pública realize acordos baseados na jurisprudência dominante, que pode divergir da interpretação inicialmente dada pela Administração Pública, ou da interpretação que lhe pareça mais confortável, ou, ainda, da interpretação que ela deduz em defesa. $\mathrm{O}$ acordo que acata a interpretação dada pelos Tribunais a determinada matéria está respeitando as balizas legais e, portanto, atendendo ao princípio da legalidade administrativa.

\footnotetext{
${ }^{430}$ SOUZA, Luciane Moessa de. Meios consensuais de solução de conflitos envolvendo entes públicos, cit., p. 172-173.

${ }^{431}$ SOUZA, Luciane Moessa de. Resolução consensual de conflitos envolvendo o Poder Público, cit., p. 162169, p. 166; VOLPI, Elon Kaleb Ribas. Conciliação na Justiça Federal: A indisponibilidade do interesse público e a questão da isonomia. Revista da PGFN. Brasília, PGFN, ano 1, n. 2, p. 139-164, 2011, p. 160.
} 
Para Elon Kaleb Ribas, a insistência na litigância ou defesa de uma posição em juízo que já tenha sido superada nos Tribunais militaria inclusive contra a legalidade:

\begin{abstract}
"Essa questão acerca do princípio da legalidade é bastante delicada. Veja-se, de um lado, que o fato de a matéria já ter sido pacificada no Judiciário, por exemplo, não implica uma relativização de tal princípio, mas, antes, está relacionado à necessária submissão de um dos poderes do Estado (Executivo) ao que foi decidido por outro poder, no caso, o Judiciário" ${ }^{432}$.
\end{abstract}

Anota o autor que, em muitos casos, a Administração pode adotar uma postura mais restritiva com a finalidade de atender a um interesse da própria Administração (secundário), como, por exemplo, uma contenção de gastos, postergando indenizações ou vedando benefícios a que a pessoa tem direito. Adicione-se a vantagem de que, tratando-se de questão que envolva o pagamento de quantia pela Administração, o efetivo desembolso será postergado, pois os valores deverão ser pagos via precatório. São estímulos para que a Administração sustente em juízo teses já superadas, o que acaba por movimentar desnecessariamente a máquina judiciária ${ }^{433}$.

Nesse ponto, é pertinente destacar a tendência de uniformização do entendimento jurisprudencial promovida por reformas nas leis processuais, ocorridas a partir da primeira metade da década de 2000. Foram criados instrumentos processuais que, em graus variáveis, fixam a orientação de decisões judiciais que envolvam a mesma matéria de direito.

O instrumento aparentemente dotado de maior abrangência é a súmula vinculante, introduzida pela Emenda Constitucional n. 45/2004, prevista no art. 103-A da Constituição, que é enunciado emitido pelo Supremo Tribunal Federal, incidente sobre validade, interpretação ou eficácia de norma de conteúdo constitucional, sobre a qual haja controvérsia entre órgãos judiciais ou entre estes e a Administração Pública, que possa causar grave insegurança jurídica ${ }^{434}$. Rodolfo de Camargo Mancuso assinala a eficácia expandida panprocessual da súmula, pois ela se estende a todos os órgãos judiciais ou à Administração Pública direta ou indireta, e seu descumprimento gera a cassação da decisão judicial ou a anulação do ato administrativo ${ }^{435}$.

Outro instrumento é a repercussão geral da questão constitucional, como requisito de admissibilidade do recurso extraordinário, também introduzido pela Emenda

\footnotetext{
${ }^{432}$ VOLPI, Elon Kaleb Ribas. Conciliação na Justiça Federal, cit., p. 139-164, 2011, p. 157.

${ }^{433}$ VOLPI, Elon Kaleb Ribas. Conciliação na Justiça Federal, cit., p. 139-164, 2011, p. 158.

${ }^{434}$ MANCUSO, Rodolfo de Camargo. Divergência jurisprudencial e súmula vinculante. 5. ed. São Paulo: RT, 2013, p. 363-364.

${ }^{435}$ MANCUSO, Rodolfo de Camargo. Divergência jurisprudencial e súmula vinculante, cit., p. 364.
} 
Constitucional n. 45/2004, que passou a ser previsto no art. 102 , $\S 3^{\circ}$, da Constituição Federal, possuindo dupla finalidade. Por um lado, é "fator de alívio" que busca evitar que o STF precise se ocupar de questões de interesse restrito à esfera jurídica dos litigantes do processo "em ordem a poder reservar sua atenção e seu tempo para matérias de mais vasta dimensão, para grandes problemas cuja solução deva influir com maior intensidade na vida econômica, social, política do país"436. Por outro lado, também tem função de uniformização jurisprudencial e de "julgamento de recurso extraordinário por amostragem", pois a regulamentação dada pela Lei n. 11.418/2006, alterando o CPC, incluiu o art. 543-B, que prevê procedimento para o caso de haver recursos extraordinários fundados na mesma controvérsia. Segundo tal artigo, o órgão colegiado de origem encaminhará recursos representativos da controvérsia, encaminhando-os ao STF e sobrestando os demais. Se a repercussão geral for negada nos recursos paradigma, os demais automaticamente não serão conhecidos na origem; se o mérito do recurso for julgado com repercussão geral reconhecida, haverá a possibilidade de retratação pelo órgão colegiado de origem, aplicando o entendimento do STF ou julgando o recurso prejudicado. Caso a decisão seja mantida pelo órgão de origem, caberá ao STF adequá-la à orientação firmada no julgamento paradigma. O procedimento pode ser utilizado de ofício ou a requerimento da parte interessada, conforme o art. 328 do Regimento Interno do STF.

Por fim, destaca-se o julgamento em bloco de recursos especiais repetitivos, previsto no art. 543-C, do CPC, incluído pela Lei n. 11.672/2008. Em sistemática parecida, quando houver multiplicidade de recursos especiais com fundamento em mesma questão de direito, o tribunal de origem escolherá admitirá um ou mais representativos, e os demais ficarão sobrestados. Também no Superior Tribunal de Justiça, poderá o relator sobrestar os recursos existentes na segunda instância que versem sobre a mesma controvérsia. Quando for publicado o acórdão do Superior Tribunal de Justiça, os recursos especiais sobrestados na origem: (i) "terão seguimento denegado na hipótese de o acórdão recorrido coincidir com a orientação do Superior Tribunal de Justiça” ou (ii) “ serão novamente examinados pelo tribunal de origem na hipótese de o acórdão recorrido divergir da orientação do Superior Tribunal de Justiça".

Há, contudo, o alerta de que a utilização dos recursos repetitivos deveria servir mais para gerenciar processos em situações já pacificadas pela jurisprudência, e não para desafiar a jurisprudência já pacificada, modificando-a ou, ainda, para dirimir as

\footnotetext{
${ }^{436}$ MOREIRA, José Carlos Barbosa. Reforma do Judiciário: a Emenda Constitucional no 45 e o Processo. Revista Magister de Direito Civil e Processual Civil, n. 11, mar/abr 2006.
} 
divergências constantes nos tribunais em matérias não pacificadas sobre as quais o debate não tenha maturado o suficiente. Recomenda-se essa ponderação no uso dessas técnicas, não obstante se observe no STJ um forte uso do julgamento de recursos especiais por amostragem $^{437}$.

Essa tendência de instrumentos que propiciem resolução em blocos de demandas judiciais e que aspiram à uniformização jurisprudencial vem acentuada na nova redação do Código de Processo Civil, aprovada em 17.12.2014 no Senado Federal, onde a sistemática de tratamento de recursos especiais e extraordinários repetitivos é unificada, tendo sido dedicada toda uma seção ao tema (arts. 1.033 a 1.038).

Ademais, prevê novo instrumento processual ao qual deu o nome de "incidente de resolução de demandas repetitivas”, que permite às partes, ao juiz, ao Ministério Público ou à Defensoria Pública, ainda em primeiro grau, identificando "demandas repetitivas", remeter a questão ao Tribunal para que se pronuncie sobre a tese jurídica adequada ao caso (art. 988 e $\S \S)$, que será aplicada a todos os processos individuais ou coletivos sob a jurisdição do tribunal e aos casos futuros que venham a ser ajuizados (art. 982). É instrumento que, ademais, "poderia contribuir para a resolução do problema da multiplicidade de ações individuais relativas a interesses que também se configuram, na jurisdição coletiva, como individuais homogêneos" ${ }^{\star 38}$. É possível vislumbrar, ainda no dispositivo, um veículo para o próprio litigante repetitivo obter na jurisdição daquele Tribunal uma uniformização da jurisprudência em casos de seu interesse, pois lhe é conferida legitimidade para suscitar o incidente, envolvendo-o assim na responsabilidade pela racionalização da litigância repetitiva, ainda que seu dever, sobretudo tratando-se de ente público, não se limita à atuação processual.

Apesar disso, subsistem algumas críticas. Por exemplo, haveria, nos recursos repetitivos, incerteza sobre o momento adequado e o nível de pacificação da discussão jurídica necessário para utilização de técnicas como o julgamento por amostragem no STJ

\footnotetext{
${ }^{437}$ Cf. SOUZA, Michel Roberto. Recurso especial repetitivo: análise crítica do julgamento por amostragem. Dissertação (Mestrado) - Faculdade de Direito da Universidade de São Paulo. São Paulo, 2014, p. 113-115.

438 FALLEIROS, Carolina Teodoro. Alcance subjetivo das decisões judiciais sobre interesses metaindividuais. Dissertação (Mestrado) - Faculdade de Direito da Universidade de São Paulo. São Paulo, 2014, p. 144.
} 
do recurso especial repetitivo ${ }^{439}$. Além disso, haveria também dificuldades em estabelecer critérios objetivos e não arbitrários para o reconhecimento da repercussão geral ${ }^{440}$.

Ainda assim, fato é que esses instrumentos fornecem subsídios para a prática de acordos no âmbito da justiça, reduzindo a tramitação processual.

Vale retomar que, no âmbito federal, há normas que levam em consideração a jurisprudência dos tribunais superiores como critérios para racionalizar e reduzir a litigância dos entes públicos.

A Lei n. 12.844/2013 alterou a Lei n. 10.522/2002 para prever, no artigo 19, que a Procuradoria-Geral da Fazenda Nacional está autorizada a não contestar, a não interpor recurso ou a desistir do que tenha sido interposto, desde que inexista outro fundamento relevante, na hipótese de a decisão versar sobre matérias decididas pelo STF ou pelo STJ de forma "desfavorável” à Fazenda Nacional nas formas do art. 543-B e 543-C do CPC, exceto no caso de decisão pelo art. 543-C que ainda possa ser revista pelo STF. Referida lei dispõe ainda que, nesses casos, a PGF deve, ainda, expressamente, reconhecer a procedência do pedido e a não interpor recurso quando for intimada da decisão.

Também a Lei n. 9.469/97, que dispõe sobre a atuação do Advogado-Geral da União, prevê em seu art. $4^{\circ}$ que ele "poderá dispensar a propositura de ações ou a interposição de recursos judiciais quando a controvérsia jurídica estiver sendo iterativamente decidida pelo Supremo Tribunal Federal ou pelos Tribunais Superiores". Sendo sua redação de 1997, uma atualização de sua leitura leva à conclusão de que a não propositura de ações e recursos estaria autorizada também no caso de julgamentos na sistemática dos arts. 543-B e 543-C do CPC.

Note-se que a Lei n. 12.884/2013 e a Lei n. 9.469/97 não incluem a realização de "acordo ou transação" com base na jurisprudência pacificada dos Tribunais superiores. A Lei n. 12.884/2013 vai mais longe, impondo o reconhecimento do pedido e a não interposição de recurso, inclusive em previsão mais benéfica ao indivíduo que litiga contra o Poder Público. Ambas as leis dão indicativos claros de que a Administração Pública Federal deve acatar a jurisprudência pacificada nos Tribunais, o que pode se dar não apenas por meio de composição unilateral pela Administração (desistência, renúncia, reconhecimento do pedido, não interposição) mas também de forma consensual (acordos

\footnotetext{
${ }^{439}$ Cf. SOUZA, Michel Roberto. Recurso especial repetitivo, cit., p. 159

${ }^{440}$ Cf. TARTUCE, Fernanda; BERGAMASCHI, André Luís. Repercussão Geral da Questão Constitucional em Demandas Familiares. FUX, Luiz; FREIRE, Alexandre; DANTAS, Bruno (Org.). Repercussão Geral da Questão Constitucional. Rio de Janeiro: Forense, 2014, p. 53-70, v. 1, p. 53-70, p. 61.
} 
firmados administrativa ou judicialmente, quando a Lei não imponha solução mais favorável ao reconhecimento de direitos).

Há, portanto, destaque para a função de contenção da judicialização excessiva por estes instrumentos nomofiláticos, especialmente em relação a litigantes repetitivos.

Tais dispositivos autorizativos deverão sofrer atualização, ou ter sua interpretação acomodada ao Novo Código de Processo Civil aprovado em 17.12.2014 $4^{441}$, para que se estendam aos institutos do Novo CPC correspondentes àqueles previstos no CPC (arts. 1.033 a 1.038). A interpretação sistêmica permitiria conter envolver também nas autorizações do art. 19 da Lei n. 10.522/2002 as questões decididas nos incidentes de resolução de demandas repetitivas previstos no art. 988 do novel diploma.

Trazem-se essas autorizações expressas que fazem referência às previsões de uniformização de jurisprudência como forma de demonstrar que o acatamento da posição dos tribunais é algo lícito à Administração e não fere a legalidade. Portanto, sob esse prisma, referida utilização da posição consolidada da jurisprudência pode ser feita independentemente da autorização expressa e para além das hipóteses dos arts. 543-B e 543-C, do CPC, ou da súmula vinculante. Sendo a Administração responsável pela aplicação da lei, e considerando que essa aplicação também depende de interpretação, nada impede que tal interpretação seja revista de acordo com o trabalho dos tribunais. Evidentemente, a interpretação deve ser feita por aquele a quem a compete legalmente, o que dependeria da regulamentação interna da Administração.

Elon Kaleb Ribas Volpi entende que, em juízo, o sistema de atuação consensual da Administração Pública carece de uma melhor fixação de critérios legais ${ }^{442}$, o que, de fato, cria um ambiente de menor segurança para a Administração atuar de forma consensual e evitar uma responsabilização pelos seus órgãos de controle. $\mathrm{O}$ autor defende, assim, que a lei deve criar tais critérios, sob pena de arbítrio e violação da isonomia ${ }^{443}$. Contudo, reconhece que "isso não justifica a atuação irrazoável dos advogados públicos, cuja aplicação do citado princípio não leva em conta uma interpretação sistemática" e que o “ordenamento jurídico é um sistema e, como tal, comporta interpretações que conduzam a Administração Pública à conciliação" ${ }^{\text {,44 }}$. 
Contudo, já foi registrada posição de que a atuação consensual e o acordo não dependem, em qualquer situação, de previsão legal do seu conteúdo, pois pode decorrer da interpretação da própria lei.

\subsubsection{Situações em que a lei não traz a resposta completa}

Outra situação registrada pela literatura pesquisada diz respeito às questões em que a lei não traz uma solução certa, recorrendo a critérios abertos à maior interpretação pelo Administrador.

Como acentua Luciane Moessa de Souza, a legislação nem sempre traz balizas claras para imediata identificação da solução a ser dada a um problema concreto, de forma que dentro do que a lei minimamente prevê podem ser vislumbrados muitos caminhos. Um exemplo citado pela autora é "a complexidade colocada pela colisão entre direitos fundamentais, problema para o qual a melhor solução que a doutrina constitucional conseguiu elaborar até o momento é a técnica de ponderação caso a caso, buscando preservar o núcleo essencial de cada direito" $" 445$.

Por exemplo: a preservação da biodiversidade e a integridade do patrimônio genético do país é dever do Poder Público, na condição de direito difuso previsto constitucionalmente (art. 225, II, da CF). A Política Nacional de Biodiversidade (Decreto n. 4.339/2002) estrutura-se, contudo, em previsões de diretrizes e objetivos, sem uma atribuição específica de obrigações e condutas certas a entes públicos e privados. A tutela da biodiversidade, de forma mais específica, vem prevista em leis esparsas, como a que protege especificamente a Mata Atlântica e prevê obrigações e vedações (Lei n. $11.428 / 2006)^{446}$. Contudo, a falta de regulação legal específica não é motivo para deixar de atender esse direito difuso, de forma que cabe ao Administrador competente, segundo as diretrizes legais mais amplas, a estruturação das soluções de proteção desse direito.

O potencial de conflitos é imenso, e o recurso à legalidade pura e simples nem sempre soluciona as questões. É necessário encontrar outras técnicas de compatibilização dos direitos fundamentais. Nesses casos, “a verificação das normas jurídicas aplicáveis ao caso é apenas o ponto de partida da negociação, a moldura que lhe traça os motivos". Assim, defende a autora que os acordos realizados pelo Poder Público são atos

${ }^{445}$ SOUZA, Luciane Moessa de. Meios consensuais de solução de conflitos envolvendo entes públicos, cit., p. 172-173.

${ }^{446}$ Cf. MILARÉ, Édis. Direito do ambiente. 7. ed. São Paulo: RT, 2011, p. 702 e ss. 
administrativos como os demais e, portanto, devem ser devidamente fundamentados, até porque se submetem ao controle interno e externo de juridicidade, fundamentação que deve ser fática e jurídica, para justificar porque a saída consensual é mais adequada para resolver o conflito sob os pontos de vista da legalidade ${ }^{447}$.

Nesses casos, estaria relativizada uma concepção estrita da vinculação positiva da Administração à lei, pois a Administração deveria agir, dentro de um objetivo de proteger um interesse difuso, sem uma conduta especificamente prescrita.

Juliana Bonacorsi de Palma entende que a consensualidade põe em xeque a concepção de legalidade como vinculação positiva. Tratando especificamente da negociação da prerrogativa pública sancionatória no âmbito das agências reguladoras, a autora traça considerações que podem ser aproveitadas para outros casos em que a Administração está orientada para uma finalidade:

\footnotetext{
"Ocorre que a consensualidade na prática do Direito Administrativo assume evidente viés pragmático, voltado à resolução de casos concretos com negociação de prerrogativas públicas para alcançar a resposta mais eficiente. Em um cenário marcadamente complexo, em especial no âmbito das Agências Reguladoras, em que os problemas levados à deliberação pela Administração Pública são cada vez mais particularizados, a celebração de acordos administrativos demanda elevado grau de discricionariedade para se adotar soluções efetivamente próximas ao caso concreto.

A atuação administrativa por meio de acordos suscita, assim, reflexões acerca da existência de margem de autonomia da vontade no âmbito do aparato público na medida em que os atos consensuais formalizam-se por meio da aquiescência bilateral, pública e privada, acerca dos termos do pacto (autonomia da vontade $\mathrm{x}$ vontade legal).

Seu caráter negocial e pragmático, focado na situação problema que a consensualidade se apresenta como possível instrumento, enseja a feição negativa da legalidade e mesmo a atipicidade dos termos dos acordos administrativos (vinculação negativa e atipicidade $\mathrm{x}$ vinculação positiva e tipicidade) ${ }^{, 448}$.
}

Podemos concluir que a Administração, atuando consensualmente, não poderá se afastar do critério legal de decisão, o que não significa a tradicional vinculação positiva à lei para qualquer acordo, mas sim que a Administração respeitará os limites legais naquilo que a lei regule. Por exemplo, a isenção tributária apenas pode ser criada por lei específica

${ }^{447}$ SOUZA, Luciane Moessa de. Resolução consensual de conflitos envolvendo o Poder Público, cit., p. 162 169, p. 166. Prossegue a autora, em outra obra: "Admitida a transação, deve-se garantir a máxima proteção, na medida do possível, a todos os interesses, públicos e privados, envolvidos, com primazia natural dos primeiros sobre estes últimos em caso de conflito insuperável. Todavia, os parâmetros legais, se, sem dúvida, servem como diretrizes mínimas de qualquer transação a ser celebrada nesta área, muitas vezes, serão insuficientes par abalizar um acordo sustentável, dificuldade que se acentua quanto maior for o número de interessados, bem como da utilização de um terceiro mediador ou facilitador do diálogo (...). É sempre bom lembrar, ainda, que referir-se à legalidade como parâmetro, mesmo no quadro do sistema tradicional de resolução de conflitos pela via litigiosa, ao mesmo tempo que aponta para uma referência de maior relevância, não tem o condão de proporcionar uma solução tão clara para o conflito quanto os fetichistas da legalidade parecem crer".

${ }^{448}$ PALMA, Juliana Bonacorsi de. Atuação administrativa consensual, cit., p. 277. 
(art. 150, §6, $\mathrm{CF}$ ). É reserva legal que deve ser respeitada e, portanto, um acordo não pode conceder uma isenção não prevista em lei, por mais que em sua interpretação esteja com isso alcançando alguma finalidade pública.

No mais, os graus de vinculação estrita à lei são variáveis, apesar de que, mesmo nas matérias amplamente abertas, haverá um mínimo de balizamento legal a ser seguido. No conflito em que estiver envolvida, deve-se ter em conta o nível de regulação legal da matéria colocada. Procedem as afirmações de Juliana Bonacorsi de Palma que "[a] ampliação do objeto de vinculação e a convivência de diferentes graus de vinculação à lei formal - ora positiva, ora negativa -, viabilizam a atuação administrativa consensual" ${ }^{, 49} \mathrm{e}$ que "[n]o tema da consensualidade, reconhece-se a vinculação negativa à lei formal. Como consequência, é discricionária a decisão do Poder Público de disciplinar em norma a atuação administrativa concertada para que possa satisfazer as finalidades públicas por meio de acordos 450 ,

\subsection{Dever de assegurar a isonomia}

A isonomia é previsto de forma geral no art. $5^{\circ}$, caput, da Constituição Federal, sob denominação de "igualdade", situada na literatura como princípio, direito fundamental ou garantia constitucional. No primeiro caso, seria a isonomia um postulado geral destinado ao legislador e ao Administrador no sentido de impedimento de criação de normas arbitrárias ou reconhecedoras de privilégio ${ }^{451}$. Para José Afonso da Silva, pode ser ainda situada como direito fundamental porque, para além do postulado geral que informa a ideologia do ordenamento jurídico, também designa prerrogativas concretizadas em garantias de uma convivência digna, livre e igual de todas as pessoas, mas configura também garantia constitucional geral, pois integra o conjunto de prerrogativas do cidadão oponíveis ao Estado ${ }^{452}$.

Fernanda Tartuce posiciona-se no sentido de que é possível cogitá-la nas três perspectivas sem qualquer prejuízo ou contradição, pois ela apresenta um aspecto político e o comprometimento dos agentes públicos para sua efetiva concretização, sabendo-se,

\footnotetext{
${ }^{449}$ PALMA, Juliana Bonacorsi de. Atuação administrativa consensual, cit., p. 280.

${ }^{450}$ PALMA, Juliana Bonacorsi de. Atuação administrativa consensual, cit., p. 282.

${ }^{451}$ Cf. BASTOS, Celso Ribeiro. Dicionários de Direito Constitucional. São Paulo: Saraiva, 1994, p. 161.

${ }^{452}$ SILVA, José Afonso da. Curso de Direito Constitucional Positivo. 26. ed. São Paulo, 2004, p. 178; 188 189.
} 
ainda, estar superada uma concepção estritamente liberal de igualdade formal, e presente, na concepção contemporânea, a ideia de igualdade material ${ }^{453}$, que se traduz, além do compromisso estatal de efetivamente atingi-la, na imposição ao Poder Público de “igualação dos iguais e o tratamento diversificado daqueles que se diversificam segundo critérios de Justiça racionalmente postos e suficientemente motivados"454.

Interessa ao presente trabalho, entre os diversos desdobramentos do tema, o aspecto funcional da isonomia enquanto oriente da conduta do administrador público, expressa, de forma sintética, na ideia de vedação ao discrímen injustificado. Dizer sobre "tratamento diversificado" implica, portanto, reconhecer que existem discrímens que não violam a garantia da isonomia e que, na verdade, a promovem na medida dos objetivos do ordenamento. Seriam, dessa forma, discriminações positivas legítimas aquelas que observassem, segundo Celso Antonio Bandeira de Mello, três fatores: a) o elemento tomado como fator de desigualação (fator de discrímen); b) a correlação lógica abstrata existente entre o fator erigido em critério de discrímen e a disparidade estabelecida no tratamento jurídico diversificado; c) a "consonância desta correlação lógica com os interesses absorvidos no sistema constitucional e destarte juridicizados" ${ }^{\$ 55}$.

Destaca-se o último fator: a discriminação deve estar voltada a atingir um interesse previsto constitucionalmente e juridicamente legítimo.

No Direito Administrativo, a isonomia vem por vezes refletida na impessoalidade, princípio previsto expressamente no art. 37, como fica claro em trecho de Celso Antonio Bandeira de Mello, para quem o princípio traduz "a ideia de que a Administração tem que tratar a todos os administrados sem discriminações, benéficas ou detrimentosas. (...) $\mathrm{O}$ princípio em causa não é, senão, o próprio princípio da igualdade ou isonomia"456.

Odete Medauar identifica o princípio da impessoalidade da mesma forma que a isonomia, no sentido de orientar a atuação administrativa não por questões pessoais, mas pelas finalidades das atividades administrativas:

"intuito essencial de impedir que fatores pessoais, subjetivos sejam os verdadeiros
móveis e fins das atividades administrativas. Com o princípio da impessoalidade a
Constituição visa obstacularizar atuações geradas por antipatias, simpatias, objetivos de
vingança, represálias, nepotismos, favorecimentos diversos, muito comuns em
licitações, concursos públicos, exercício do poder de polícia. Busca, desse modo, que

${ }^{453}$ TARTUCE, Fernanda. Igualdade e vulnerabilidade no processo civil, cit., p. 60, 62 .

${ }^{454}$ ROCHA, Cármen Lúcia Antunes. O princípio constitucional da igualdade. Belo Horizonte: Lê, 1990, p. 39

${ }^{455}$ MELLO, Celso Antonio Bandeira de. Conteúdo jurídico do principio da igualdade. 3. ed. São Paulo: Malheiros, 2009, , p. 21.

${ }^{456}$ MELLO, Celso Antônio Bandeira de. Curso de Direito Administrativo, cit., p. 117. 
predomine o sentido da função, isto é, a ideia de que os poderes atribuídos finalizam-se ao interesse de toda a coletividade, portanto a resultados desconectados de razões pessoais" $"$ "

Não obstante a autora liste uma série de fatores subjetivos que não podem interferir na atuação administrativa (simpatia, antipatia, etc.), é certo que isonomia deve ser aferida também por um critério estritamente objetivo, que é a finalidade da atuação administrativa em cada caso.

Transportando-se tais considerações para o âmbito da construção das soluções consensuais para conflitos envolvendo a Administração Pública, registram-se posições no sentido de que a isonomia constitui uma limitação à discricionariedade na realização de acordos e é nesse âmbito de liberdade de atuação que deve ser apurada a sua observância. A discussão resume-se à pergunta de, se uma vez realizado um acordo com o particular, outro em situação idêntica teria direito ao mesmo acordo, ou seja, se a isonomia tornaria o oferecimento do acordo um ato vinculado.

Para Luciana Moessa de Souza, devem-se ter claras duas situações, que expressam diferentes graus de identidade do conflito. Segundo a autora, se o primeiro acordo resulta de uma atividade discricionária, em que a solução consensual foi apenas uma das possibilidades de atendimento aos interesses públicos surgidos no caso concreto, entendese que daí não resulta um direito dos demais administrados ao mesmo acordo ${ }^{458}$.

Por outro lado, se há situação jurídica absolutamente idêntica, a Administração deve adotar a mesma solução para todos os casos, pois, se as situações são similares, a isonomia se impõe $\mathrm{e}^{459}$. Tome-se, por exemplo, questões em que a quantidade de variáveis objetivas é menor, como a apuração do direito a um benefício previdenciário, em que é mais fácil identificar a similitude dos casos.

Segundo Elon Kaleb Ribas Volpi, a Administração Pública não pode praticar acordos ou transações com administrados em situações idênticas que prevejam condições diferentes, a não ser que haja um motivo razoável para o discrímen. Nessas situações, haveria uma atividade vinculada do administrador público, não havendo espaço para discricionariedade, sujeitando a violação da isonomia, inclusive, ao controle judicial de validade. Para o autor, seria necessário que a lei norteasse a Administração Pública,

\footnotetext{
${ }^{457}$ MEDAUAR, Odete. Direito administrativo moderno, cit., p. 148.

${ }^{458}$ SOUZA, Luciane Moessa de. Meios consensuais de solução de conflitos envolvendo entes públicos, cit., p. 174.

${ }^{459}$ SOUZA, Luciane Moessa de. Meios consensuais de solução de conflitos envolvendo entes públicos, cit., p. 174-175.
} 
fixando critérios para o entabulamento dos acordos e, caso não fosse possível realizar o acordo nos mesmos termos, caberia ao ente público declinar os motivos da sua nãorealização, em respeito à motivação das decisões administrativas ${ }^{460}$.

É adequado o entendimento do autor quanto à vinculação dos acordos para outros casos semelhantes. Contudo, como já expostos nos itens anteriores, não parece adequado condicionar a realização de acordos à previsão dos critérios em lei, porque (i) o acordo pode decorrer da interpretação da própria lei já existente e (ii) a legalidade não é suficiente em boa parte dos casos, e (iii) a própria administração tem competência para realizar acordos e transigir, podendo, assim, fixar seus próprios critérios.

Há ponderação no sentido de que, tendo em vista que o ente público ao realizar determinada composição acaba estabelecendo um "acordo precedente", é natural que ele leve em conta se aquela situação é única ou se existem milhares de casos similares e se há viabilidade técnica de cumprimento de todos os acordos naquele sentido ${ }^{461}$.

Nesse sentido, e demonstrando a competência da própria Administração para fixar seus critérios de resolução de conflitos, é o Decreto n. 4.250/2002, que trata da representação judicial da União e de demais entes da administração federal no âmbito dos Juizados Especiais Federais, e que prevê que

\footnotetext{
Art. $5^{\circ}$.

(...)

Parágrafo único. O órgão da Administração Pública Federal que receber pedido de subsídios para a defesa da União, de suas autarquias ou fundações, nos termos do art. $4^{\circ}$ da Lei $n^{\circ} 9.028$, de 1995, além de atendê-lo no prazo assinalado:

I - verificando a plausibilidade da pretensão deduzida em juízo e a possibilidade de solução administrativa, converterá o pedido em processo administrativo, nos termos do art. $5^{\circ}$ da Lei ${ }^{\circ}$ 9.784, de 29 de janeiro de 1999, para exame no prazo improrrogável de trinta dias;

II - comunicará ao órgão solicitante a providência adotada no inciso I; e

III - providenciará a verificacão da existência de requerimentos administrativos semelhantes, com a finalidade de dar tratamento isonômico (grifo nosso).
}

Nota-se que o decreto em questão estabeleceu a possibilidade de a Administração examinar administrativamente a pretensão do autor deduzida no Juizado Especial Federal, podendo reconhecê-la administrativamente, além impor-lhe a obrigação de verificar a existência de requerimentos administrativos semelhantes para que dê a mesma solução.

Podemos exemplificar o descrímen motivado com um dos casos pesquisados no âmbito do Município de São Paulo. Foi instituído pela Lei Municipal n. 14.129/2006 o

\footnotetext{
${ }^{460}$ VOLPI, Elon Kaleb Ribas. Conciliação na Justiça Federal, cit., p. 139-164, 2011, p. 162.

${ }^{461}$ SOUZA, Luciane Moessa de. Resolução consensual de conflitos envolvendo o Poder Público, cit., p. 162169, p. 166-167.
} 
Programa de Parcelamento Incentivado, mediante o qual se pretendia "a regularização de créditos do Município, decorrentes de débitos tributários, constituídos ou não, inclusive os inscritos em Dívida Ativa, ajuizados ou a ajuizar, em razão de fatos geradores ocorridos até 31 de dezembro de 2004" (art. $1^{\circ}$ ). Segundo o artigo $4^{\circ}$, os devedores poderiam pagar tais débitos à vista, com um desconto de $75 \%$ da multa, ou parcelado, com um desconto de $50 \%$ da multa.

Poderiam os sujeitos devedores com fatos geradores ocorridos depois de 31 de dezembro de 2004 avocar o direito à mesma forma de pagamento, por questão de isonomia? A motivação da limitação do período em que ocorridos os fatos geradores dos créditos foi clara: como a própria lei declara, o Município pretendia, com o programa, aumentar a arrecadação efetiva com dívidas fiscais não regularizadas e com fato gerador até o final do exercício de 2004, reduzindo o inadimplemento já existente, sendo essa sua finalidade. A justificativa para a limitação no tempo foi a seguinte: se o programa de parcelamento com perdão de multa fosse permanente ou muito frequente, o contribuinte seria estimulado a seguir o programa em vez do recolhimento regular do tributo, prejudicando a previsibilidade mínima da arrecadação e enfraquecendo-a nos moldes normais. Por isso, haveria um descrímen justificado entre indivíduos com dívidas fiscais de diferentes "idades", que estaria diretamente ligado ao objetivo da medida e, portanto, não feriria a isonomia.

\subsection{Sistema de precatórios}

Sabe-se que a Administração Pública não sofre execução no processo civil tal qual os particulares. Há previsão constitucional no sentido de que

\footnotetext{
“[o] s pagamentos devidos pelas Fazendas Públicas Federal, Estaduais, Distrital e Municipais, em virtude de sentença judiciária, far-se-ão exclusivamente na ordem cronológica de apresentação dos precatórios e à conta dos créditos respectivos, proibida a designação de casos ou de pessoas nas dotações orçamentárias e nos créditos adicionais abertos para este fim" (art. 100 - grifo nosso).
}

O uso de "Fazenda Pública" nada mais designa que a personificação do Estado. A expressão é utilizada, de forma geral, para designar os entes da Administração Pública direta ou indireta que figurem em ações judiciais. Apesar do termo "Fazenda", em um sentido mais restrito estar relacionada com a área da Administração que cuida da gestão das finanças do Estado, o termo "Fazenda Pública" não se limita aos processos judiciais 
que envolvam matéria fiscal ou financeira ${ }^{462}$. Assim, o dispositivo constitucional tem alcance a todas as causas envolvendo a Administração Pública direta ou indireta, em todas as esferas federativas.

O sistema de cumprimento das sentenças das quais decorram obrigação de pagar decorre da ideia de que os bens públicos são impenhoráveis, de forma que seria ineficaz promover-se a execução civil nos moldes previstos para os demais sujeitos, baseada na expropriação de bens ${ }^{463}$.

Assim, a execução contra a "Fazenda Pública" é promovida nos moldes do art. 730 do Código de Processo Civil, em que o ente público é citado para apresentar embargos, e não o fazendo, ou sendo eles julgados improcedentes, o juízo da execução solicita ao presidente do Tribunal competente a expedição do precatório com ordem para a autoridade pública incluí-lo no orçamento geral, e efetuar o pagamento no exercício financeiro seguinte $^{464}$. A partir daí, o pagamento respeitará a ordem de apresentação do precatório, tendo preferência os “débitos de natureza alimentícia”, assim definidos no art. $100, \S 1^{\circ}$, da $\mathrm{CF}$, e sobre estes ainda terão preferência os "débitos de natureza alimentícia cujos titulares tenham 60 (sessenta) anos de idade ou mais na data de expedição do precatório ${ }^{465}$, ou sejam portadores de doença grave, definidos na forma da lei”, com a limitação do valor preferencial prevista no $\S 2^{\circ}$ do mesmo artigo.

Naturalmente, a previsão constitucional de pagamento dos valores decorrentes de sentença judicial e de seu pagamento até o final do exercício seguinte ao da inclusão (art. $100, \S 5^{\circ}$, da $\mathrm{CF}$ ) não foi suficiente para que a Administração Pública de fato cumprisse essas determinações, o que dependeria de dinheiro público suficiente disponível.

Some-se a isso o aumento das competências e de direitos sociais e difusos a serem tutelados pelo Estado de acordo com a Constituição Federal de 1988, o que também representou um crescimento da judicialização e das condenações da Administração. Assim,

\footnotetext{
${ }^{462}$ CUNHA, Leonardo Carneiro da. A fazenda pública em juízo. 12. ed. São Paulo: Dialética, 2014, p. 15. ${ }^{463}$ CUNHA, Leonardo Carneiro da. A fazenda pública em juízo. 12. ed. São Paulo: Dialética, 2014, p. 322. ${ }^{464}$ CUNHA, Leonardo Carneiro da. A fazenda pública em juízo. 12. ed. São Paulo: Dialética, 2014, p. 327. ${ }^{465}$ Note-se, contudo, que a expressão "na data da expedição do precatório" foi reputada inconstitucional pelo STF, sob o seguinte fundamento: "A expressão "na data de expedição do precatório", contida no art. 100, $\S 2^{\circ}$, da $\mathrm{CF}$, com redação dada pela $\mathrm{EC} \mathrm{n}^{\circ} 62 / 09$, enquanto baliza temporal para a aplicação da preferência no pagamento de idosos, ultraja a isonomia ( $\mathrm{CF}$, art. $5^{\circ}$, caput) entre os cidadãos credores da Fazenda Pública, na medida em que discrimina, sem qualquer fundamento, aqueles que venham a alcançar a idade de sessenta anos não na data da expedição do precatório, mas sim posteriormente, enquanto pendente este e ainda não ocorrido o pagamento". Assim, a interpretação dada pelo Tribunal é que crédito do idoso se tornaria preferencial tão logo ele completasse 60 (sessenta) anos no curso da espera pelo pagamento (BRASIL. Supremo Tribunal Federal. Ação Direta de Inconstitucionalidade n. 4425-DF. Órgão Julgador: Tribunal Pleno. Relator: Ministro Ayres Britto. Relator p/o acórdão: Ministro Luiz Fux. J. em: 14/03/2013. DJe em: 18/12/2013).
} 
é notório que a maioria dos entes públicos não conseguiu cumprir as prescrições constitucionais.

O Município de São Paulo registra, segundo dados do Tribunal de Justiça atualizados em 28/11/2014, 11.167 precatórios pendentes de pagamento, com ordens orçamentária expedidas desde 1982, enquanto o Estado de São Paulo registra 6.069 precatórios com ordens expedidas desde $1984^{466}$. Dados do Conselho Nacional de Justiça apurados entre 5 e 9 de março de 2012 demonstram que o Estado de São Paulo tinha acumulado, em 2012, um total de $\mathrm{R} \$ 24.476 .531 .606,66$ (vinte e quatro bilhões, quatrocentos e setenta e seis milhões, quinhentos e trinta e um mil, seiscentos e seis reais e sessenta e seis centavos) em precatórios ${ }^{467}$.

Ante tal situação, a Emenda Constitucional n. 20/98 criou uma exceção ao regime de precatórios constante no art. $100, \S 3^{\circ}$, qual seja a obrigação definida em lei como “pequeno valor". Depois, sobreveio a Emenda Constitucional n. 30/2000, permitindo, conforme o $\S 4^{\circ}$, que cada entidade de direito público defina esse valor conforme sua capacidade econômica. Com o advento da Emenda n. 62/2009, a definição desse valor deve respeitar piso do valor igual ao maior benefício do regime geral da previdência social $^{468}$.

Em nova solução buscada pelo legislador, foi promulgada a Emenda Constitucional n. 62/2009, que instituiu um "regime especial de pagamento de precatórios" ( $§ 15$ do art. 100), que concedia aos entes públicos em mora com o pagamento de seus precatórios duas possibilidades de quitá-los: (i) mediante um mínimo de destinação de percentuais da receita líquida, percentuais estes estabelecidos no art. 97, $2^{\circ}$, do Ato das Disposições Constitucionais Transitórias (ADCT), sendo o mínimo depositado em conta especial; ou, ainda, (ii) pela adoção do regime especial pelo prazo de até 15 (quinze) anos.

${ }^{466}$ Disponível em: <http://www.tjsp.jus.br/cac/scp/webRelPublicLstPagPrecatPendentes.aspx>. Acesso em: 31.11.2014.

467 CONSELHO NACIONAL DE JUSTIÇA. Relatório precatórios. Brasília: CNJ, 2012, p. 95-97. Disponível

<http://www.cnj.jus.br/images/imprensa/precatorios/realtorio_precatorios_CNJ_FINAL1.pdf>. Acesso em: 31.11.2014.

${ }^{468}$ Prevê o art. 87 do Ato das Disposições Constitucionais Transitórias (ADCT) que, [p]ara efeito do que dispõem o $\S 3^{\circ}$ do art. 100 da Constituição Federal e o art. 78 deste Ato das Disposições Constitucionais Transitórias serão considerados de pequeno valor, até que se dê a publicação oficial das respectivas leis definidoras pelos entes da Federação, observado o disposto no $\S 4^{\circ}$ do art. 100 da Constituição Federal, os débitos ou obrigações consignados em precatório judiciário, que tenham valor igual ou inferior a: I - quarenta salários-mínimos, perante a Fazenda dos Estados e do Distrito Federal; II - trinta salários-mínimos, perante a Fazenda dos Municípios". 
Foi prevista ainda a possibilidade de $50 \%$ dos valores depositados na mencionada conta especial serem destinados a pagamento de precatórios por meio de leilão ou por acordo direto entre o ente público e o credor, "na forma estabelecida por lei própria da entidade devedora, que poderá prever criação e forma de funcionamento de câmara de conciliação" ( $§ 8^{\circ}$ do art. 97 do ADCT).

No entanto, o art. 100, §15, da CF e o art. 97 do ADCT foram julgados inconstitucionais pelo Supremo Tribunal Federal, segundo fundamentação expendida pelo Relator Ministro Ayres Brito,

\footnotetext{
"[p]enso adequada a referência à Emenda Constitucional no 62/2009 como a "emenda do calote". Calote que termina por ferir o princípio da moralidade administrativa, que se lê no caput do art. 37 da Constituição Federal, na medida em que se reconheça - como pessoalmente reconheço - o adimplemento das próprias dívidas como um dos necessários conteúdos do princípio da moralidade administrativa. Noutros termos, o Estado reconhece que não cumpriu, durante anos, as ordens judiciais de pagamento em desfavor do Erário; propõe-se a adimpli-las, mas limitado o valor a um pequeno percentual de sua receita. Com o que efetivamente força os titulares de créditos assim inscritos a levá-los a leilão. Certame em que o objeto a ser "arrematado" é o direito à execução de sentença judicial transitada em julgado! E que tem por "moeda", exatamente, perdão de parte desse direito! Pelo que se verifica, de pronto, a inconstitucionalidade do inciso I do $\S 8^{\circ}$ e de todo o $\S 9^{\circ}$, ambos do art. 97 do ADCT. E o que dizer do "acordo direto" constante do inciso III do $\S 8^{\circ}$ do art. 97 do ADCT? Certamente não rima com os princípios da impessoalidade e da moralidade, por tornar fortemente subjetivo o critério de escolha para pagamento de precatórios."
}

O resultado, por outro lado, não surtiu efeitos imediatos para os regramentos já estabelecidos pelos entes públicos em relação ao art. 97 do ADCT, estando pendente, até esta data, questão de ordem relativa à modulação dos efeitos da declaração de inconstitucionalidade, conforme sessão realizada em 19/03/2014. Além disso, há medida cautelar com liminar deferida autorizando a continuidade pelos Tribunais dos pagamentos de precatório conforme o sistema que viesse sendo aplicado na data do julgamento.

\subsubsection{Pagamento por precatório: óbice à realização de acordo?}

Situado o atual estágio de disciplina dos precatórios, resta analisar como os precatórios e a atuação consensual da Administração Pública se relacionam. São óbices à adoção de resolução de conflitos por acordo nas vias administrativa e judicial? Caso não sejam, o pagamento de um acordo deve se sujeitar à ordem de precatórios?

Desde logo, devemos excluir da discussão os acordos que envolvam as assim chamadas "obrigações de pequeno valor", que são pagas em prazos fixos, conforme 
estipulado pela lei do ente federativo ${ }^{469}$. Igualmente, devemos nos ater às sentenças judiciais que se sujeitariam a precatório, ou seja, apenas aqueles que implicam pagamento pecuniário, excluindo-se daí todos os provimentos que não envolvem pagamento, como os mandamentais, declaratórios, constitutivos e, ainda, as obrigações de fazer, não fazer ou entregar coisas, modalidades que submetem a Administração Pública às mesmas formas de cumprimento a que se submete um particular ${ }^{470}$.

Outra consideração a ser feita é que apenas se cogita falar em precatório nos casos em que os valores a serem pagos derivem de acordos firmados em juízo, com sentença homologatória. Se o acordo ou transação for feita administrativamente, seu pagamento não se submete ao regime diferenciado.

Logo, a princípio, o sistema de cumprimento de sentenças que impliquem pagamento de valores não é óbice para realização de acordos, ao menos nos casos em que tal regime não se aplica.

Resta saber se acordos pecuniários podem ser feitos e se submeteriam ao regime dos precatórios. Na doutrina, há uma variedade de entendimentos.

Para Luciane Moessa de Souza, a essência do sistema de pagamentos por precatório é a isonomia. Portanto, se há uma condição diferenciada daquele que praticou o acordo, ou seja, se ele abriu mão de parte de seu crédito, não há problemas em abreviar o tempo de recebimento dos valores. O litigante que deixou de abrir mão de uma quantia se submete, portanto, à espera do pagamento do precatório. O problema, para autora, estaria na mesma isonomia de que tratamos no tópico anterior: se é dada a possibilidade de troca do "desconto" no valor do crédito pela antecipação do pagamento, a mesma oportunidade deve ser dada a todos os credores, o que dependeria, segundo a autora, de um ato normativo específico. É o critério da "vantagem" que determinaria se um acordo seria pago ou não via precatório.

Para Rodolfo de Camargo Mancuso, a vedação estaria em não comprometer verba orçamentária já especificamente afetada ao pagamento de precatórios que aguardam na fila da ordem cronológica, o que poderia configurar desvio de finalidade passível de ação

469 No âmbito federal, o art. 17 da Lei n. 10.259/2001 prevê que nos Juizados Especiais Federais, o pagamento, com limite de sessenta salários mínimos, será feito em sessenta dias contados da entrega da ordem à autoridade. No Estado de São Paulo, o limite foi estipulado pela Lei Estadual n. 11.377/2003 em 1.135,2885 Unidades Fiscais do Estado de São Paulo - UFESPs (art. $1^{\circ}$ ), hoje aproximadamente R\$ 22.864,71, e o pagamento se dará em noventa dias (art. $1^{\circ}, \S 2^{\circ}$ ).

${ }^{470}$ MANCUSO, Rodolfo de Camargo. O plano Piloto de conciliação em segundo grau de jurisdição, do E. Tribunal de Justiça de São Paulo, e sua possível aplicação aos feitos de interesse da Fazenda Pública, cit., p. 44-45. 
popular (art. $2^{\circ}$, da Lei n. 4.717/65), bem como ato de improbidade (art. 10, inciso XI, da Lei n. $8.429 / 92)^{471}$.

Já para Carlos Ari Sundfeld e Jacintho Arruda Câmara, o crédito decorrente de acordo judicial, com vantagem (não necessariamente pecuniária, ao menos no que denota o texto), não se submeteria ao regime de precatório e seu pagamento não constituiria burla ao sistema desenhado constitucionalmente. Isso porque teria origem em decisão de índole administrativa e não judicial, pois a Administração, ao celebrar um acordo, está reconhecendo, integral ou parcialmente, o direito pleiteado pelo particular. No caso do precatório, este constituiria uma ordem que parte do Poder Judiciário e não da própria manifestação da Administração ${ }^{472}$.

Os autores vão mais longe, ao afirmar a possibilidade de celebração desse acordo mesmo já em fase de execução, mas antes da expedição do precatório, porque a ordem estabelecida no art. 100 da CF é exigível apenas de pagamentos por precatório já expedido. Assim, não faria sentido submeter o reconhecimento de direitos pela via administrativa (à qual se equipararia o acordo judicial) à ordem de precatórios, o que não acontece com outros pagamentos de débitos reconhecidos administrativamente (como adimplementos de contratos vigentes, por exemplo) ${ }^{473}$.

Tampouco a superveniência da Emenda Constitucional n. 62/2009 altera o entendimento dos autores. Isso porque o diploma criou, além do parcelamento, um mecanismo de vinculação das receitas públicas à quitação dos créditos decorrentes de precatório, que apenas aos seus titulares beneficia. Portanto, a celebração de acordos para resolver disputas judiciais que não foram objeto de precatório expedido não violaria essa $\operatorname{garantia}^{474}$.

O STF vem se manifestando no sentido de que a transação, acordo ou conciliação feita pelo Poder Público, mesmo que resultem em vantagem financeira para a Administração, não devem implicar inversão da ordem cronológica de precatórios, de onde de poderia inferir que os créditos derivados de acordos judiciais deveriam ser cumpridos mediante expedição de precatório.

\footnotetext{
${ }^{471}$ MANCUSO, Rodolfo de Camargo. O plano Piloto de conciliação em segundo grau de jurisdição, do E. Tribunal de Justiça de São Paulo, e sua possível aplicação aos feitos de interesse da Fazenda Pública, cit., p. 46-47.

${ }^{472}$ SUNDFELD, Carlos Ari; CÂMARA, Jacintho Arruda. Acordos na execução contra a Fazenda Pública. Revista Eletrônica de Direito Administrativo Econômico. Salvador, IBDP, n. 23, ago./out. 2010, p. 7. ${ }^{473}$ SUNDFELD, Carlos Ari; CÂMARA, Jacintho Arruda. Acordos na execução contra a Fazenda Pública. Revista Eletrônica de Direito Administrativo Econômico. Salvador, IBDP, n. 23, ago./out. 2010, p. 8. ${ }^{474}$ SUNDFELD, Carlos Ari; CÂMARA, Jacintho Arruda. Acordos na execução contra a Fazenda Pública. Revista Eletrônica de Direito Administrativo Econômico. Salvador, IBDP, n. 23, ago./out. 2010, p. 9.
} 
No julgado mais recente localizado, o Ministro Marco Aurélio manifestou-se no seguinte sentido:

\begin{abstract}
Nem mesmo a celebração de transação com o Poder Público, ainda que em bases vantajosas para o erário, teria, na época em que ocorridos os fatos expostos na denúncia, o condão de autorizar a inobservância da ordem de precedência cronológica dos precatórios, pois semelhante comportamento - por envolver efetivação de despesa não autorizada por lei e por implicar frustração do direito de credores mais antigos, com evidente prejuízo para eles - enquadra-se no preceito incriminador constante do inciso $\mathrm{V}$ do art. $1^{\circ}$ do Decreto-Lei n ${ }^{\circ} 201 / 67$. Doutrina. Precedentes".
\end{abstract}

Na realidade, transações favoráveis à entidade estatal celebradas com credores menos antigos, como Luiz Gastão de Alencar Franco de Carvalho, desrespeitam a ordem de precedência dos precatórios, ainda que exonerem o erário de encargos financeiros mais gravosos.

Trata-se de argumento que viola a própria essência e razão de ser da norma inscrita no art. 100 da Constituição, cujo propósito teleológico consiste em inibir tratamentos discriminatórios ou em impedir abusos administrativos que eventualmente possam vir a ocorrer nas relações obrigacionais postas, em tema de execução contra a Fazenda Pública, sob regime constitucional de direito público - existentes entre credores particulares (exequentes) e a Fazenda Pública (executada). ${ }^{475}$

Melhor compulsando o caso narrado, consistente em ação penal por crimes de responsabilidade de prefeito, previstos no art. $1^{\circ}$, incisos IV e V, do Decreto-Lei n. 201 de 1967, verifica-se que o problema, na verdade, foi a falta de dotação orçamentária própria para realização do acordo e o emprego de empréstimo obtido junto ao BID para projeto de transporte público específico para quitação do precatório. Contudo, na fundamentação, e a título de obiter dictum, o Relator deixou claro no trecho acima seu entendimento sobre a matéria, realçando, inclusive, que não apenas a observância da ordem de precatórios, mas também a sua própria expedição são exigências constitucionais.

Em outro caso, o Ministro Celso de Mello consignou que

"[o] pagamento antecipado de credor mais recente, em detrimento daquele que dispõe de precedência cronológica, não se legitima em face da Constituição, pois representa comportamento estatal infringente da ordem de prioridade temporal, assegurada, de maneira objetiva e impessoal, pela Carta Política, em favor de todos os credores do Estado.

O pagamento antecipado que daí resulte - exatamente por caracterizar escolha ilegítima de credor - transgride o postulado constitucional que tutela a prioridade cronológica na satisfação dos débitos estatais, autorizando, em conseqüência - sem prejuízo de outros efeitos de natureza jurídica e de caráter político-administrativo -, a efetivação do ato de

475 BRASIL. Supremo Tribunal Federal. Ação Penal n. 503-PR. Órgão julgador: Tribunal Pleno. Relator: Min. Marco Aurélio. J. em: 20/05/2010. DJe em: 31/01/2013. Prossegue o relator: "Não se pode perder de perspectiva que a exigência constitucional de expedição do precatório, com a consequente obrigação imposta ao Estado de estrita observância da ordem cronológica de apresentação daquele instrumento de requisição judicial de pagamento, tinha (e tem, ainda, na maioria dos casos) por finalidade impedir favorecimentos pessoais indevidos e frustrar injustas perseguições ditadas por razões de caráter político-administrativo". 
seqüestro (RTJ 159/943-945), não obstante o caráter excepcional de que se reveste essa medida de constrição patrimonial ${ }^{476}$.

O STF já se pronunciou no mesmo sentido em outras oportunidades: Agravo de Instrumento n. 519.969/ES, por decisão monocrática do Ministro Cézar Peluso ${ }^{477}$; Reclamação n. 2848/CE, de relatoria do Ministro Joaquim Barbosa ${ }^{478}$; Reclamação n. 1979/RN, de relatoria do Ministro Maurício Correa ${ }^{479}$.

Os casos, contudo, contemplam situações em que o acordo foi realizado após a expedição do precatório, e que houve a negociação de um precatório mais recente para adiantar o seu pagamento. Não tratam de acordos realizados ainda durante a fase de conhecimento ou antes da expedição do precatório, ainda que revelem, incidentalmente, que a própria expedição do precatório já uma medida necessária para a isonomia. Os julgados não dão uma diretriz clara para afirmar se a Administração, ao realizar acordo na pendência da ação, deve pagá-los por expedição de precatório.

Para caso de acordos realizados antes do trânsito em julgado da sentença em ação de conhecimento, parece lógico entender que tal composição que reconheça, total ou parcialmente, o direito do particular, não seja submetida ao sistema de precatórios, tenha ou não vantagem econômica. Isso porque, de fato, não seria um crédito reconhecido em sentença, após clara resistência da Administração Pública, mas sim por decisão da própria Administração, o que se aproxima do reconhecimento administrativo.

Se tal crédito fosse submetido ao sistema de precatórios, poder-se cogitar a violação da isonomia entre o administrado que teve seu direito reconhecido espontaneamente na via administrativa, e receberá imediatamente os valores devidos, e aquele que, por algum erro ou equívoco de interpretação da Administração, estava em semelhantes condições, mas teve que acessar o Poder Judiciário para ter seu direito declarado.

Em casos em que a Administração formula acordos para reconhecimento de direitos, também o critério do "desconto" esbarraria na questão da isonomia: por que o indivíduo que tem seu direito reconhecido administrativamente há de receber os valores correspondentes integral e imediatamente e aquele que tem o direito reconhecido em um

476 BRASIL. Supremo Tribunal Federal. Embargos declaratórios na Reclamação n. 3220-CE. Órgão julgador: Tribunal Pleno. Relator: Ministro Celso de Mello. J. em: 24/04/2008. DJe em: 13/02/2013.

${ }^{477}$ BRASIL. Supremo Tribunal Federal. Agravo de instrumento n. 519969-ES. Relator: Min. Cézar Peluso. J. em: 07/04/2006. DJ em: 27/04/2006.

${ }^{478}$ BRASIL. Supremo Tribunal Federal. Reclamação n. 2848-CE. Órgão julgador: Tribunal Pleno. Relator: Min. Joaquim Barbosa. J. em: 27/10/2005. DJ em: 24/02/2006.

${ }^{479}$ BRASIL. Supremo Tribunal Federal. Reclamação n. 1979-RN. Órgão julgador: Tribunal Pleno. Relator: Min. Maurício Correa. J. em: 16/05/2002. DJ em: 02/08/2002. 
acordo, mas na pendência de uma ação judicial, deve aguardar o precatório ou conceder um desconto à Administração?

De fato, os atos de reconhecimento de direitos são muito aproximados a tais acordos. Jefferson Carús Guedes aponta que o reconhecimento de direitos pela Administração não é incomum e se dá a todo o momento, seja por meio de atos administrativos ou por meio de normas gerais, como a Medida Provisória n. 201/2004 (posteriormente convertida na Lei n. 10.999/2004) ${ }^{480}$, que reconheceu o direito à correção monetária pelo Índice de Reajuste do Salário Mínimo (IRSM) aos beneficiários da previdência social.

Acrescente-se, já em vias de conclusão sobre o tema, a advertência feita por Mancuso de que o pagamento de acordos judiciais não deve ser feito com recursos do previamente afetados ao pagamento de precatórios, conforme acima destacado.

Por outro lado, de fato, a isonomia tem de ser respeitada, não podendo a Administração Pública, sem uma justificativa razoável, discriminar casos semelhantes e praticar o acordo em alguns, revendo a sua posição, e em outros não, relegando estes à execução contra a Fazenda Pública e, consequentemente, à espera do pagamento por precatório.

Além disso, como bem reconhecido por Carlos Ari Sundfeld e Jacintho Arruda Câmara, na interpretação mais liberal possível do tema, a ordem de precatórios em si é garantia constitucional, ao menos após expedido o precatório, de forma que não se pode reputar válido um acordo que burle essa lista. A exceção ficaria por conta de desequiparações devidamente justificadas e autorizadas pela própria Constituição, como é o caso do art. $97, \S 8^{\circ}$, do ADCT que, embora tenha tido sua inconstitucionalidade declarada pelo STF, em um "pacote" que levou consigo todos os parágrafos do mesmo dispositivo, baseou por muito tempo a criação de mecanismos de redução do estoque de precatórios.

É exemplo disso o Decreto Municipal n. 52.011/2010 (Município de São Paulo), que previu a vinculação de verba orçamentária própria para quitação de precatórios no mesmo exercício com cinquenta por cento de desconto, oportunidade que foi oferecida a

${ }^{480}$ GUEDES, Jefferson Carús. Transigibilidade de interesses públicos: prevenção e abreviação de demandas da Fazenda Pública. ; SOUZA, Luciane Moessa de. Advocacia de Estado: questões institucionais para a construção de um estado de justiça - Estudos em homenagem a Diogo de Figueiredo Moreira Neto e José Antonio Dias Toffoli. Belo Horizonte: Fórum, 2009, p. 243-273, p. 246. 
todos e não violou nem a isonomia entre os optantes do desconto, nem a isonomia entre estes e os demais que estavam na fila.

\subsection{Publicidade dos atos administrativos}

A confidencialidade é normalmente apontada como uma das grandes vantagens da utilização dos meios alternativos de solução de conflitos. Na mediação, diz-se normalmente que há a garantia de que toda a informação obtida pelo mediador ou pelas partes se manterá dentro do programa, a não ser que haja autorização por todas as partes envolvidas $^{481}$.

A Resolução n. 125/CNJ, ao estabelecer o Código de Ética de Conciliadores e Mediadores Judiciais, prevê dentre os princípios e garantias que regem a sua atuação a confidencialidade, definida como "dever de manter sigilo sobre todas as informações obtidas na sessão, salvo autorização expressa das partes, violação à ordem pública ou às leis vigentes, não podendo ser testemunha do caso, nem atuar como advogado dos envolvidos, em qualquer hipótese" (art. $1^{\circ}$, inc. I). Daí se depreende que, naturalmente, as sessões de mediação ou conciliação serão sigilosas.

Da mesma forma, o recém-aprovado Código de Processo Civil prevê no art. 166 que a confidencialidade é um dos princípios da conciliação e da mediação e prevê que ela "[se] estende a todas as informações produzidas no curso do procedimento, cujo teor não poderá ser utilizado para fim diverso daquele previsto por expressa deliberação das partes".

Figura também como princípio no art. $2^{\circ}$, inciso VII, do Projeto de Lei $n$. 7169/2014, da Câmara dos Deputados. O art. 31 do Projeto traz as exceções, logo no caput, prevendo que a confidencialidade se aplica "salvo se as partes expressamente decidirem de forma diversa ou quando sua divulgação for exigida por lei ou necessária para cumprimento de acordo obtido pela mediação" (art. 31). Também exclui a informação relativa a ocorrência de crime de ação penal pública $\left(\xi^{\circ}\right)$ e a prestação de informações à Administração Tributária $\left(\S 4^{\circ}\right)$.

$\mathrm{Na}$ outra mão, temos o princípio constitucional da publicidade, que rege a Administração Pública (art. 37 da CF), e que "impõe que todos os atos do procedimento sejam previamente levados a conhecimento público, que a prática de tais atos se faça na presença de qualquer interessado e que o conteúdo do procedimento possa ser conhecido

${ }^{481}$ CALMON, Petronio. Fundamentos da mediação e da conciliação. 2. ed. Brasília: Gazeta Jurídica, 2013, p. 116. 
por qualquer um" ${ }^{482}$. Tem dupla funcionalidade: (i) assegura a todos a obtenção de informações e (ii) contribui para a transparência da administração, desincentivando práticas reprováveis ${ }^{483}$..

A publicidade, contudo, não é absolutamente irrestrita, comportando exceções que derivam da ponderação entre tal princípio e outros de estatura constitucional. A Lei de Acesso à Informação (Lei n. 12.527/2011) prevê, por exemplo, em seu art. 23, categorias de informações consideradas "imprescindíveis à segurança do Estado ou da sociedade" e que, portanto, podem ter seu acesso obstado e tornado sigiloso.

A Constituição também prevê restrições à publicidade dos atos processuais (que se aplica, naturalmente, aos processos administrativos), como os casos em defesa da intimidade ou interesse social (art. $5^{\circ}$, inciso LX) e, ainda, casos de segurança da sociedade ou do Estado (art. $5^{\circ}$, inciso XXXIIII).

Resta, porém, questionar se as sessões de mediação ou conciliação estariam sujeitas à publicidade ou se a Resolução do CNJ e, agora, o recém-aprovado Código de Processo Civil configurariam exceção legal legítima ao princípio.

Evidentemente, a publicidade não seria um óbice absoluto à adoção de meios consensuais de solução de conflitos pela Administração Pública. Contudo, sendo princípio regente da Administração Pública, justamente porque existe a necessidade de controle interno e externo, é uma peculiaridade que, a princípio, deve ser levada em conta na modelação da utilização dos meios consensuais. Assim, o sigilo que normalmente é atribuído como uma vantagem das ADRs deve ser limitado, sendo a questão principal saber em que grau isso deve ser feito.

Em primeiro lugar, nem toda utilização de meios não judiciais e consensuais de solução de conflitos contém a realização de um "evento", uma "sessão" em que as partes estejam presentes física ou remotamente. Em muitos casos, a composição consensual pode se dar por um processo administrativo completamente escrito, nos quais, segundo o art. $2^{\circ}$ da Lei do Processo Administrativo (Lei n. 9.784/99), a publicidade apenas é mitigada nos casos de sigilo previstos na Constituição. A discussão se mostra relevante naqueles casos em que são realizadas reuniões ou audiências como etapas da construção da solução consensual, como é comum acontecer nos casos de conciliação e mediação.

A resposta pode ser buscada nos próprios motivos da confidencialidade normalmente atribuída à mediação e à conciliação.

\footnotetext{
482 JUSTEN FILHO, Marçal. Curso de Direito Administrativo, cit., p. 353.

483 JUSTEN FILHO, Marçal. Curso de Direito Administrativo, cit., p. 353-354.
} 
Para Luciane Moessa de Souza, o objetivo da confidencialidade é permitir que as partes fiquem mais à vontade para negociar, além de se justificar pela necessidade de que as partes confiem no conciliador ou mediador ${ }^{484}$.

Nesse ponto, devemos ter em conta que a mediação ou a conciliação nem sempre se dão em um único ato e não necessariamente envolvem sessões conjuntas a todo o momento. Uma das ferramentas existentes para melhor extrair resultados da mediação é o caucus, ou sessão privada, em que apenas uma das partes participa com o mediador, como uma forma intencional de restringir a comunicação entre as partes. Os objetivos de tais reuniões são facilitar a definição de interesses, esclarecer posições, identificar novas ofertas ou considerar propostas das outras partes, pontos que podem ser dificultados dependendo da dinâmica da reunião conjunta. Outras vezes, o caucus é usado para revelar informações confidenciais ao conciliador ou mediador, que não podem ser reveladas na sessão conjunta ${ }^{485}$.

A solução da questão da confidencialidade dada por Luciane Moessa de Souza pondera a existência de diferentes técnicas, no curso do processo em que esteja envolvida a Administração Pública. Pode ser necessário que sejam realizadas sessões privadas com apenas uma das partes, nas quais os entes públicos ou os particulares revelem informações que não desejam que cheguem ao conhecimento da outra parte por diversos motivos, entre eles a possibilidade de enfraquecimento na negociação. Para o bem do próprio método, é necessário que o conciliador ou mediador mantenha sigilo sobre as informações dadas no momento do caucus, a não ser que elas se enquadrem nas exceções da confidencialidade. Por outro lado, não se poderia admitir a confidencialidade das sessões conjuntas e nem da documentação produzida durante o processo, nem de seu resultado. A publicidade é a regra e a confidencialidade é exceção, devendo ser juridicamente justificada, demonstrando-se que há suporte jurídico para o sigilo, como nos casos já narrados ${ }^{486}$

O objetivo de controle é claro. Na seara internacional, fala-se em without prejudice principle, que prescreve as regras de admissibilidade de provas e prevê que, a partir de um processo de mediação que não tenha gerado acordo, tudo o que for revelado ao longo da mediação não pode ser utilizado em processos que se seguirem, como arbitragem ou

\footnotetext{
${ }^{484}$ SOUZA, Luciane Moessa de. Resolução consensual de conflitos envolvendo o Poder Público: caminho possível e adequado, com o devido respeito às peculiaridades do regime jurídico-administrativo. Revista do Advogado. São Paulo, AASP, n. 123, ago.2014, p. 162-169, p. 167.

${ }^{485}$ SAMPAIO, Lia Regina Castaldi; BRAGA NETO, Adolfo. O que é mediação de conflitos. Sp. 64-65.

${ }^{486}$ SOUZA, Luciane Moessa de. Resolução consensual de conflitos envolvendo o Poder Público: caminho possível e adequado, com o devido respeito às peculiaridades do regime jurídico-administrativo. Revista do Advogado. São Paulo, AASP, n. 123, ago.2014, p. 162-169, p. 167.
} 
processo judicial. Contudo, essa regra é mitigada, sendo uma das exceções a análise sobre o cumprimento ou não de um acordo. Outra exceção para o uso dessas informações é na análise da validade do acordo, ou se este foi produzido com problemas de representação, fraude ou sob alguma influência indevida (como coação) ${ }^{487}$.

O que pode se extrair dessas lições é que, para que o meio consensual bem funcione e seja capaz de gerar soluções qualitativamente justas e válidas juridicamente, é necessário que ela não esteja imune a sistemas de controle. A confidencialidade absoluta pode ser um entrave a esse controle. No caso de meios consensuais e Administração Pública, o controle deve ser mais intenso, pois é possível que qualquer cidadão esteja apto a fazê-lo, bem como os órgãos institucionalizados de controle (Ministério Público, Tribunais de Contas, etc.).

No âmbito da arbitragem, em autorizada aproximação, também se defende a mitigação do sigilo normalmente atribuído a ela, quando uma das partes for um ente da Administração Pública. Nesse sentido:

\begin{abstract}
Em verdade, a questão do sigilo da arbitragem em questões de que participam o Estado, que, em princípio, seria contrária aos princípios jurídico-administrativos da publicidade e da transparência, dos mais caros à administração pública, tem sido objeto de estudos e reflexão, surgindo o conceito de que tal sigilo não é um dogma a ser seguido em toda $\mathrm{e}$ qualquer arbitragem e que as conveniências do Estado em submeter seus contratos à arbitragem não deve ser repelida em função desse tratamento sigiloso, que pode ser dispensado ou abrandado pelas partes, na convenção arbitral, pois esta, em realidade, não raro se fazem adaptações nas regras institucionais de entidades administradoras de arbitragens em temas não vitais ao instituto, como este parece ser. Ou pode estabelecer regras e fazer ajustes onde a lei não disciplina de forma cogente alguma fórmula procedimental $^{488}$.
\end{abstract}

Também Justino de Oliveira entende que não é admitido segredo no trato dos assuntos públicos, tampouco na arbitragem contratual $^{489}$.

487 UDAYAKUMAR, Anand Ayyapan. Is 'mediation privilege' necessary to uphold confidentiality in mediation? Revista de Arbitragem e Mediação. São Paulo, RT, v. 36, p. 287-291, jan./mar. 2013, p. 288289.

${ }^{488}$ GARCEZ, José Maria Rossani. O Estado, suas agências, as empresas públicas e as sociedades de que participa na arbitragem privada. Recentes progressos. Revista de Arbitragem e Mediação, São Paulo, Revista dos Tribunais, n. 8, p. 101-118, jan./mar. 2006, p. 112.

489 OLIVEIRA, Gustavo Henrique Justino de. A arbitragem e as parcerias público-privadas. Revista

Eletrônica de Direito Administrativo Econômico. Salvador, IDPB, n. 2, mai./jul. 2005, p. 24-25. 


\section{CRÍTICAS AOS MEIOS CONSENSUAIS}

O presente capítulo foca objeções levantadas contra a utilização de meios alternativos de solução de conflitos, especialmente os consensuais.

Mesmo nos Estados Unidos, o movimento das ADRs não avançou sem objeções contundentes que, mesmo que não tenham barrado seu desenvolvimento, levantaram importantes hipóteses sobre efeitos negativos da utilização de meios alternativos de solução de conflitos, o que contribuiu para seu aprimoramento bem como para o esclarecimento sobre a adequação ou não de tais alternativas em determinadas situações.

Em oposição ao ambiente de estímulo e elogio às ADRs da Harvard Law School, o Yale Law Journal, ligado à Universidade de Yale, publicou, em 1984, um artigo do Professor Owen Fiss, processualista, que é considerado um dos mais importantes escritos sobre $\mathrm{ADRs}^{490}$.

Owen Fiss vê com ceticismo as promessas do movimento das ADRs em promover a redução da litigância, pois o interesse nesses mecanismos não estaria limitado à mediação e negociação prévia ao litígio, mas se estenderia à própria ação judicial. Assim, segundo o autor, os partidários da ADRs estariam procurando novas formas de facilitar e até de pressionar as partes em resolver um processo judicial em andamento por acordo ${ }^{491}$.

Em movimento que repercutiu inclusive no Brasil, a Rule 16 do Federal Rules of Civil Procedure tornou a facilitação do acordo um propósito explícito dos encontros prélitígio, onde os participantes são "convidados" (expressão usada ironicamente pelo autor) a considerar a solução do caso consensualmente. A Rule 68 já previa o pagamento das custas incorridas após o oferecimento de um acordo rejeitado, caso o julgamento fosse menos favorável do que o acordo. Segundo Fiss, os incentivos aos acordos estavam sendo intensificados por uma proposta de emenda em que a parte que não aceitasse o acordo deveria pagar os honorários do advogado da outra, caso o julgamento fosse menos favorável $^{492}$. A proposta excepciona da regra as class actions ou derivadas ${ }^{493}$.

Segundo Fiss, há uma visão valorativa do Judiciário que baseia o entusiasmo com as ADRs e com a solução pelo acordo: a adjudicação seria "apenas" uma forma de solução

\footnotetext{
${ }^{490}$ FISS, Owen. Against Settlement. The Yale Law Journal, New Haven, v. 93, n. 6, mai./1984, p. 1073 1090.

${ }^{491}$ FISS, Owen. Against Settlement, cit., p. 1073-1090, p. 1073.

${ }^{492}$ Ao que consta, a proposta não frutificou, não tendo ocorrido tal alteração no momento previsto por Fiss (Cf. http://www.law.cornell.edu/rules/frcp/rule_68). Quis o autor demonstrar com esse apontamento a tendência de obtenção do acordo em substituição ao julgamento e a qualquer custo.

${ }^{493}$ FISS, Owen. Against Settlement, cit., p. 1073-1090, p. 1074.
} 
de conflitos, ou seja, consistiria simplesmente em um terceiro estranho que, por meio do exercício de poder, compõe o conflito ${ }^{494}$. Essa visão, Fiss nos conta mais tarde, difere da sua, que exalta o Poder Judiciário como instituição de promoção de justiça e condutor dos valores que inspiram a lei e a constituição norte-americanas.

Os entusiastas das ADRs, então, reconhecem que quando duas partes delegam ao Judiciário a solução de um conflito, há um rompimento prévio das relações sociais, mas esperam que as partes sejam capazes de compor por si mesmas o conflito, o que é preferível, pois constitui solução baseada no consenso. Para o autor, tal consenso é o acordo, representativo de "mais uma trégua do que verdadeira reconciliação" 495 , o que não seria preferível à adjudicação, ao menos não como uma prática genérica e indiscriminada.

$\mathrm{Na}$ área cível, seria o equivalente ao plea bargaining na área criminal, onde (i) o consentimento é frequentemente coagido, (ii) não há clareza sobre quem é o sujeito mais adequado para decidir sobre o acordo, (iii) a ausência de um julgamento justo perante a Corte gerará problemas de envolvimento judicial posterior, e (iv) ainda que um acordo seja obtido, a justiça pode não ser feita. Para ele, o acordo é mais uma "capitulação às condições da sociedade de massa, e não deve ser encorajada ou elogiada"496.

$\mathrm{O}$ elogio aos meios consensuais e o incentivo à sua implantação existem no Brasil há algum tempo. O relato da preferência dos meios consensuais no lugar da adjudicação aparece, por exemplo, no texto "Cultura de sentença e cultura de pacificação" de Kazuo Watanabe, em que são exultados os resultados do Plano Piloto em Segundo Grau de Jurisdição no Tribunal de Justiça de São Paulo, em que o índice de acordo em 2003 foi de $35 \%$ para as conciliações realizadas; o que significa que, "se na primeira instância tivesse havido uma tentativa mais empenhada de conciliação, provavelmente cerca de $30 \%$ a $40 \%$ dessas causas teriam sido encerradas mediante solução amigável, sem necessidade de recurso" 497 . Indica o autor, ao final de seu texto, que "a atual cultura de sentença será, com certeza, paulatinamente substituída pela cultura de pacificação" 498 .

De fato, de lá para cá, como já visto, o movimento resultou na implantação de variadas experiências, com alguns focos de resistência, como é o caso de conflitos envolvendo o Poder Público. Contudo, alguns problemas também se fizeram notar. Com base no texto de Fiss, nos próximos tópicos traremos as quatro críticas por ele formuladas,

\footnotetext{
${ }^{494}$ FISS, Owen. Against Settlement, cit., p. 1073-1090, p. 1075.

${ }^{495}$ FISS, Owen. Against Settlement, cit., p. 1073-1090, p. 1075.

${ }^{496}$ FISS, Owen. Against Settlement, cit., p. 1073-1090, p. 1075.

${ }^{497}$ WATANABE, Kazuo. Cultura da sentença e cultura da pacificação, cit., p. 689.

${ }^{498}$ WATANABE, Kazuo. Cultura da sentença e cultura da pacificação, cit., p. 690.
} 
e mais algumas identificadas na literatura nacional sobre o tema; relacionando-as, ainda aos riscos envolvidos na adoção de práticas consensuais em casos que envolvem o Poder Público.

\subsection{Inbalance of power: a desigualdade de forças na negociação pode promover desigualdade}

A primeira objeção levantada é o desequilíbrio de forças (inbalance of power). Segundo Fiss, a visão dos defensores das ADRs pressupõe que todas as partes envolvidas têm uma estrita igualdade de forças e tratam o acordo como a antecipação do julgamento, como se fosse simples decorrência da previsão desse resultado.

Todavia, o autor pontua que o acordo também se resulta em função do poder financeiro das partes e de quanto elas dispõem para financiar a litigância, e esses recursos quase sempre não são distribuídos igualmente. Aponta o autor que os conflitos podem não envolver apenas dois vizinhos em pé de igualdade, mas também envolvem uma minoria racial contra a polícia municipal em uma alegação de abuso, ou um singelo trabalhador contra uma grande corporação. A habilidade em ignorar os custos do processo vai invariavelmente afetar o processo da barganha, e o acordo vai contrariar um conceito de justiça que busca tornar a riqueza das partes irrelevante ${ }^{499}$.

As três formas pelas quais a riqueza das partes afeta o acordo são: (i) a parte mais pobre pode ser prejudicada na análise da informação necessária para prever o resultado da litigância, o que é uma desvantagem no processo negocial; (ii) uma das partes pode necessitar imediatamente dos recursos e pode ser compelida a fazer o acordo como uma forma de antecipar o pagamento, mesmo sabendo que assim conseguirá menos. Assim, um autor pobre pode ser explorado por um réu rico que pode forçá-lo a aceitar menos do que ele tem direito; (iii) a parte mais pobre pode ser forçada ao acordo porque ela não tem condições de arcar com os custos da litigância. Segundo Fiss, pode parecer que o acordo favorece o autor na medida em que o permite evitar os custos da demanda, mas, na verdade, o réu pode prever os custos em que o autor incorreria se demandasse até o final e deduzi-los da proposta de acordo. Assim, o autor pobre é vítima dos custos da litigância mesmo se ele fizer um acordo.

${ }^{499}$ FISS, Owen. Against Settlement, cit., p. 1073-1090, p. 1076. 
O autor ainda não acredita que arranjos como remuneração contingencial (cobrada pelo advogado apenas ao final) ou assistência jurídica possam ajudar a equalizar a relação. A primeira apenas faz o litigante pobre vulnerável ao advogado que investe em sua causa. A exploração do autor pobre, nesse caso, é transferida do réu rico para advogados que exigem uma grande fatia do resultado. E essa remuneração pelo êxito sequer é oferecida quando a parte em desvantagem é ré. Sobre a segunda, o autor aponta a escassez de subsídios governamentais para tais serviços na área cível ${ }^{500}$.

Por outro lado, reconhece que o desequilíbrio de forças pode afetar também o resultado do julgamento, pois interfere na qualidade da apresentação de provas e argumentos. Contudo, esse desequilíbrio é compensado pela presença do juiz, que pode empregar inúmeras medidas para diminuir esse impacto, como compensar a qualidade da apresentação fazendo perguntas, determinar a oitiva de testemunhas e chamar instituições e pessoas para participar como amici curiae.

A despeito dessas medidas terem um efeito tênue, nem mesmo elas são possíveis no processo de acordo. Em suas palavras, "existe uma diferença crítica entre um processo como o acordo, que é baseado na barganha e aceita diferenças de riqueza como componente integral e legítimo do processo, e um processo judicial, que sabidamente luta contra essas diferenças"

A objeção também é levantada, de forma mais sintética, por Michele Taruffo, para quem a mediação não está em condições de resolver problemas de desigualdade existentes entre as partes, o que torna possível que o procedimento gere decisões injustas, não apenas porque a dimensão jurídica do conflito não é integralmente levada em conta como também porque a parte mais forte está sempre em capacidade de impor à mais fraca a solução mais vantajosa para si. Em comparação, o processo judicial tradicional possui mecanismos de equilibrar as forças dos litigantes em juízo, ao menos no que toca ao procedimento, como tornar indisponíveis determinados direitos, deixar de aplicar-lhes regras de preclusão, etc. Por outro lado, o meio consensual pressupõe justamente o contrário, ou seja, a disposição do direito ${ }^{502}$.

Transportando as considerações para o campo dos conflitos que envolvem o Poder Público, temos o agravante de que a Administração Pública, em muitos casos, encontra-se

\footnotetext{
${ }^{500}$ FISS, Owen. Against Settlement cit., p. 1073-1090, p. 1077.

${ }^{501}$ FISS, Owen. Against Settlement, cit., p. 1073-1090, p. 1078.

502 TARUFFO, Michele. Páginas sobre justicia civil (Trad. Maximiliano Aramburo Calle). Madrid: Marcial Pons, 2009, p. 117-118.
} 
em uma situação de litigância repetitiva, em que acessa frequentemente o Poder Judiciário, o que lhe gera vantagens negociais observadas por Maria Cecília de Araújo Asperti: (i) possuir mais poder de barganha do que o litigante eventual; (ii) ter mais recursos (financeiros) para contratação de advogados; (iii) possuir mais informações sobre os procedimentos e sobre os conflitos em si; (iv) beneficiar-se da confidencialidade dos meios alternativos, inclusive dos consensuais (o que, no caso do Poder Público, é mitigado); (v) conseguir escolher o procedimento que lhes será mais vantajoso; (vi) por manterem contato com os terceiros com frequência, firmam um relacionamento (convivência) com estes e possuem mais elementos para escolher mediadores e conciliadores com os quais estejam familiarizados ${ }^{503}$.

As críticas formuladas procedem e devem ser levadas em consideração sempre que houver a opção pelo uso do meio consensual: se há desnível de poder entre as partes e, ainda, se uma das partes é litigante repetitivo, isso deve refletir tanto no desenho institucional de um programa de solução consensual que envolva os entes públicos quanto na atuação individual de cada conciliador e mediador.

Para muitos dos que defendem a adoção dos meios consensuais pelo Poder Público, a diferença de poder é evidente, mas não é um obstáculo intransponível, havendo medidas que podem ser tomadas para minimizar essa diferença: (i) a negociação direta deve ser substituída por um sistema em que haja um terceiro imparcial; (ii) esse terceiro deve indicar a necessidade de se buscar um advogado ou perito técnico para aconselhá-lo, além de assegurar se a parte entendeu as questões técnicas e jurídicas em jogo; (iii) mediador ou conciliador deve assegurar o compartilhamento de informações relevantes; (iv) deve, ainda, assegurar os interesses legítimos daqueles que não se encontram à mesa de negociação ${ }^{504}$.

Para Luciane Moessa de Souza, um bom parâmetro para identificar se a mediação é adequada ou não para determinado caso é buscar compará-la com processo adversarial tradicional, de natureza administrativa ou judicial. Em suas palavras:

Será que processo contencioso, com seu formalismo e rigoroso sistema de preclusões, oferece maiores condições de igualdade? Será que o processo judicial, em que tantas e tantas vezes a questão de direito material é esquecida em prol de discussões processuais, e em que é comum que o "vencedor" seja quem melhor manipula o procedimento, por ter o melhor advogado, é um processo baseado em maior equilíbrio de poder? É

${ }^{503}$ ASPERTI, Maria Cecília de Araújo. Meios consensuais de resolução de disputas repetitivas, cit., p. 87.

504 SOUZA, Luciane Moessa de. Resolução consensual de conflitos envolvendo o Poder Público: caminho possível e adequado, com o devido respeito às peculiaridades do regime jurídico-administrativo, cit., p. 162169 , p. 168 
evidente que não. As possibilidades de enfrentar o desequilíbrio de poder, em realidade, são mais profícuas na mediação ${ }^{505}$.

A observação comporta temperamentos. Há diretrizes no processo civil moderno que levam o juiz a conduzir o processo de forma a minimizar os efeitos deletérios da diferença de poder e condições de litigância existentes entre as partes. Nesse sentido, emerge como relevante o conceito de vulnerabilidade processual que, segundo Fernanda Tartuce, é a "suscetibilidade do litigante que o impede de praticar os atos processuais em razão de uma limitação pessoal involuntária ensejada por fatores de saúde e/ou ordem econômica, informacional, técnica ou organizacional de caráter permanente ou provisório" ${ }^{506}$. Para a autora, o conceito sustenta uma série de previsões legais que permitem o tratamento diferenciado de litigantes em juízo para facilitar sua atuação ${ }^{507}$ (algumas bastante conhecidas, como a assistência judiciária gratuita e a inversão do ônus da prova em favor do consumidor) e, ainda, permite ao juiz na condução do processo, independentemente de previsão legal, identificando a condição de vulnerável do litigante, reler as previsões de regras processuais e superar a posição de desvantagem causada pela vulnerabilidade $^{508}$. Dessa forma, o juiz, na adjudicação, dispõe de mecanismos para superar a diferença de poder entre as partes.

Por outro lado, esse conceito de vulnerabilidade se aplica também à conciliação e à mediação, e de forma mais ampla, pois a diferença de poder entre as partes pode não advir do poderio econômico, mas de características pessoais, como a autoconfiança e a habilidade de se comunicar bem, ou de posições fortes, como a determinação em não ceder, situações nas quais também seria lícito ao conciliador intervir ${ }^{509}$.

As formas de atuação do mediador/conciliador para reequilíbrio já foram tratadas no item 4.6. retro, valendo ressaltar que, nesses casos, havendo intervenções sob o fundamento do reequilíbrio, não haverá rompimento da imparcialidade ${ }^{510}$.

${ }^{505}$ SOUZA, Luciane Moessa de. Resolução consensual de conflitos envolvendo o Poder Público: caminho possível e adequado, com o devido respeito às peculiaridades do regime jurídico-administrativo, cit., p. 162169 , p. 168.

506 TARTUCE, Fernanda. Igualdade e vulnerabilidade no processo civil, cit., p. 184.

${ }^{507}$ TARTUCE, Fernanda. Igualdade e vulnerabilidade no processo civil, cit., p. 225-226.

${ }^{508}$ TARTUCE, Fernanda. Igualdade e vulnerabilidade no processo civil, cit., p. 285-287.

${ }^{509}$ TARTUCE, Fernanda. Igualdade e vulnerabilidade no processo civil, cit., p. 310.

${ }^{510}$ Outra forma peculiar de superar o desnível de poder é apontada por Frank Sander: Ao tratar do Fact Finding e mencionar sua potencialidade como forte indutor de acordos, e, se o fact-finder agir com respeito às partes e prolatar considerações efetivamente imparciais, as partes dificilmente reúnem argumentos para rejeitá-las. Em uma negociação que envolve disparidade de poder (como na relação Estado-cidadão, citada nominalmente pelo autor), a parte mais fraca pode obter vantagem no uso dessa ferramenta, ainda que o terceiro não possa proferir uma decisão vinculante (SANDER, Frank E. A. Varieties of Dispute Processing. 
Quanto à característica do Poder Público como litigante repetitivo, considerando que ele reúne mais informações sobre o caso e sobre as vantagens e desvantagens das opções de fazer um acordo ou levar a questão a julgamento, uma forma que se destaca para minimizar os efeitos é a assessoria jurídica adequada do litigante individual, como destaca Asperti:

Se os litigantes repetitivos conseguem angariar mais informações sobre o procedimento e sobre os impactos da litigância repetitiva, é de se esperar que consigam exercer mais plenamente a sua auto-determinação no âmbito da mediação e da conciliação. É neste ponto que reside a importância da assessoria jurídica em disputas repetitivas, como forma de munir os últimos das informações necessárias para exercer livremente seu direito de transigir ou de levar sua demanda a julgamento ${ }^{511}$.

De fato, na Resolução no 125/2010 do CNJ é previsto que os Centros Judiciais de Solução de Conflitos e Cidadania deverão oferecer, além da mediação e da conciliação, serviços de atendimento e orientações aos cidadãos (art. $8^{\circ}$ ), apesar de não prever um mecanismo para que, no curso da mediação ou conciliação, o interessado obtenha assessoria jurídica.

O PL n. 7.169/2014 preocupa-se com a questão, ao prever, no art. 10, que “comparecendo quaisquer das partes acompanhada de advogado ou defensor público, o mediador suspenderá o procedimento, até que todas estejam devidamente assistidas" $\left(\S 1^{\circ}\right)$, e que "aos que comprovarem insuficiência de recursos será assegurada assistência pela Defensoria Pública" $\left(\S 2^{\circ}\right)$.

No mais, estando envolvidos litigantes repetitivos, não apenas no nível da atuação individual do conciliador ou mediador, mas também na do arranjo institucional voltado à oferta de meios consensuais, deve ser pensada tal situação, com consideração das condições de acesso e de orientação jurídica, bem como às formas de atuação das partes no âmbito da conciliação e mediação judiciais ${ }^{512}$.

No próximo tópico, abordaremos uma situação em que a disparidade de poder é clara: os conflitos entre particulares e o INSS. A partir dele, pretende-se melhor esclarecer como, na realidade brasileira, a disparidade de poder pode afetar de forma sistêmica e nem sempre desejável a prática dos meios consensuais.

LEVIN, Leo A.; WHEELER, Russell R (edit.). The Pound Conference: Perspectives on Justice in the future. St. Paul, MN: West Publishing, 1979, p. 66-87, p. 70).

511 ASPERTI, Maria Cecília de Araújo. Meios consensuais de resolução de disputas repetitivas, cit., p. 142.

512 ASPERTI, Maria Cecília de Araújo. Meios consensuais de resolução de disputas repetitivas, cit., p. 139. 


\subsubsection{O caso previdenciário}

A conciliação feita no âmbito previdenciário suscita questionamentos ligados ao desnível de poder entre as partes e como isso pode reverter em situações desvantajosas à parte mais fraca. $\mathrm{O}$ presente trabalho não comportou uma pesquisa empírica específica sobre a questão, portanto, foram utilizadas apenas fontes secundárias.

Marco Aurélio Serau Júnior narra que as ações previdenciárias já são pautadas por uma grande assimetria de poder, pois, em de seus polos está um dos maiores repeated players do nosso Judiciário (o INSS) e, de outro, os segurados one-shooters, assimetria esta acentuada pelo fato de que o segurado disputa um benefício importantíssimo, que fará diferença em sua vida, enquanto para o INSS a demanda é apenas mais uma entre centenas de milhares. O segurado se encontra em um ambiente em que, além de necessitar do objeto da demanda (de forma que se torna mais suscetível ao tempo do processo), encontra-se em vulnerabilidade econômica e técnica em relação ao INSS, pois a percepção geral de magistrados, procuradores e serventuários é de que são desinformados e mal representados no âmbito judicial ${ }^{513}$.

O autor, baseado em sua própria percepção e envolvimento com o tema, explica que esse quadro leva o INSS a formular acordos apenas quando sabe de antemão que terá uma derrota judicial. Até aí, não haveria grandes problemas nessa prática. Contudo, os acordos formulados resumem-se a um abatimento do valor devido ao segurado em troca do reconhecimento imediato do benefício e pagamento dos valores em atraso ${ }^{514}$.

Para o autor, o que ocorre não é o acordo. O acordo se daria se houvesse uma zona cinzenta, imprecisa, que poderia gerar controvérsia a respeito do valor do benefício ou de seu termo inicial. A percepção dos magistrados que atuam nas conciliações é de que há um "mercado de desconto de direitos" e, segundo o autor, o "acordo" nada mais é que um "calote chancelado pelo Judiciário" 515 .

As propostas são feitas em termos fechados e são normalmente alheias a critérios objetivos legítimos. O que ocorre nos acordos é que “o risco marginal (prejuízo) recai

513 SERAU JÚNIOR, Marco Aurélio. Conciliação nas ações previdenciárias. Revista do Advogado. São Paulo, AASP, n. 123, ago./2014, p. 129-133, p. 130.

${ }^{514}$ SERAU JÚNIOR, Marco Aurélio. Conciliação nas ações previdenciárias, cit., p. 129-133, p. 131.

${ }^{515}$ SERAU JÚNIOR, Marco Aurélio. Conciliação nas ações previdenciárias, cit., p. 129-133, p. 131. 
unilateralmente sobre um dos lados do conflito, tornando-se financeiramente mais vantajosa a solução adjudicada" 516 .

De fato, estamos diante de um caso em que o sistema processual, próprio da solução adjudicada, pode oferecer mais justiça que a solução consensual (se praticada nas bases narradas) através do aprimoramento de instrumentos processuais, como, por exemplo: (i) a sedimentação da possibilidade de concessão de tutela antecipada nessas ações $^{517}$, de forma a possibilitar que o segurado frua, desde o início da ação, o benefício pleiteado; (ii) a consolidação da jurisprudência de que os valores recebidos de boa-fé pelo segurado beneficiado pela tutela antecipada não são repetíveis; (iii) a criação da "Requisição de Pagamento de Pequeno Valor", que permite que valores até sessenta salários mínimos sejam pagos imediatamente, independentemente da expedição de precatório $^{518}$.

Além disso, a prática sistematizada de celebrar acordos que impliquem em ônus financeiro para a parte vulnerável, depois de ter negado o direito na via administrativa, gerando o já mencionado "mercado de desconto de direitos", não é condizente com a legalidade, a moralidade administrativa e a boa-fé. Ao se notar a prática relatada pelo autor, ecoa imediatamente a crítica de Owen Fiss ao modelo consensual de solução de conflitos e a existência de grandes disparidades de poder.

Para Serau Júnior,

\footnotetext{
${ }^{516}$ SERAU JÚNIOR, Marco Aurélio. Conciliação nas ações previdenciárias, cit., p. 129-133, p. 131.

517 Já houve discussões sobre o cabimento da tutela antecipada em ações condenatórias contra o Poder Público, em razão, em um primeiro momento, pela previsão do art. 2-B da Lei n. 9.494/97, segundo a redação da Medida Provisória n. 2.180-19, que previa que "a sentença proferida em ação cautelar só poderá ter caráter satisfativo quando transitada em julgado a sentença proferida na ação principal", de forma genérica, e, na sequência, na redação dada ao mesmo dispositivo pela Medida Provisória n. 2.180-35/2000, que passou a prever a restrição do transito em julgado apenas para a execução de sentença "que tenha por objeto a liberação de recurso, inclusão em folha de pagamento, reclassificação, equiparação, concessão de aumento ou extensão de vantagens a servidores da União, dos Estados, do Distrito Federal e dos Municípios, inclusive de suas autarquias e fundações". Para Cássio Scarpinella Bueno, a norma, apesar de falar em "sentenças", claramente limita a efetividade das decisões que concedem a tutela antecipada, infelizmente, ao menos para as matérias elencadas (BUENO, Cássio Scarpinella. O Poder Público em juízo. 2. ed. São Paulo: Saraiva, 2003, p. 186-188). No mais, também se discutiu se seria cabível a tutela antecipada contra a Fazenda Pública por suposta incompatibilidade com o sistema do reexame necessário a que também se submeteriam as decisões concessivas de tutela antecipada. Nesse ponto, contudo, a tese restou superada e o consenso se estabeleceu no sentido de que não se sujeita ao reexame necessário a decisão que concede tutela antecipada (Cf. CUNHA, Leonardo Carneiro da. A Fazenda Pública em juízo. 12. ed. São Paulo: Dialética, 2014, p. 293-294). Hoje, ainda que com as ressalvas do art. $2^{\circ}$-B da Lei n. 9.494/97 entendidas como válidas, nas ações previdenciárias não se aplica óbice e tem-se tranquila a possibilidade de tutela antecipada para implementação do benefício, inclusive cogitando-se a possibilidade de tutela antecipada de ofício no caso de segurado vulnerável (Cf. TARTUCE, Fernanda. Igualdade e vulnerabilidade no processo civil, cit., p. 326).

${ }^{518}$ Cf. art. $17, \S 1^{\circ}$, da Lei n. $10.259 / 2001$.
} 
um modelo de conciliação previdenciária, na via judicial, é legítimo mesmo que tenha como finalidade a proposta de redução de acervo de processos. Mas, para tanto, é necessário que tome em consideração algumas cautelas e resguardos em virtude de essa pauta lidar com direitos fundamentais e as partes em conflito serem caracterizadas por notáveis assimetrias $^{519}$.

Contudo, mesmo no caso em tela, a prática não seria um óbice para a adoção de um modelo consensual se a conciliação ou mediação fosse realizada de forma cuidadosa com a parte vulnerável.

As propostas do autor são seguir o princípio da decisão informada e o empoderamento da parte, através da atuação do conciliador, provendo-lhe todas as informações necessárias sobre lei e jurisprudência para que possa decidir livremente qual a melhor forma de solucionar seu conflito ${ }^{520}$.

No caso das conciliações em causas previdenciárias, a condução normalmente é feita por um serventuário da justiça, não contando com a participação do magistrado. É importante, segundo o autor, que o mediador ou conciliador esteja pronto para orientar o segurado (diretriz que deve ser seguida em todos os casos em que há profundo desnível de poder) sobre a sua situação, os requisitos para concessão dos benefícios, a orientação da jurisprudência majoritária, para que, assim, tome uma decisão devidamente informada e a conciliação ou mediação alcance efetivamente a proteção do direito previdenciário em jogo. Sem esses cuidados, o autor acredita que de fato a via consensual não é a mais efetiva na solução e controle dos conflitos previdenciários ${ }^{521}$.

A pesquisa empírica realizada por Maria Cecília Asperti junto ao Centro de Conciliação da Justiça Federal em São Paulo, notou a existência de proposta com "desconto" dos valores devidos quando o INSS vê que perderá o processo judicial. Conforme sua pesquisa, nos casos que demandam perícia médica e, caso ela seja favorável à concessão do benefício, os autos são enviados para o contador para cálculo do valor a ser pago. Com os cálculos em mãos, o INSS costuma oferecer um desconto de $20 \%$ nas prestações vencidas e implementar imediatamente o benefício. Em razão desse desconto, alguns juízes resistem a encaminhar casos envolvendo esses benefícios previdenciários para conciliação, entendendo que é mais vantajoso ao segurado aguardar a sentença de

\footnotetext{
${ }^{519}$ SERAU JÚNIOR, Marco Aurélio. Conciliação nas ações previdenciárias, cit., p. 129-133, p. 131.

${ }^{520}$ SERAU JÚNIOR, Marco Aurélio. Conciliação nas ações previdenciárias, cit., p. 129-133, p. 131-132.

${ }^{521}$ SERAU JÚNIOR, Marco Aurélio. Conciliação nas ações previdenciárias, cit., p. 129-133, p. 132.
} 
mérito e receber os valores em atraso integralmente. A pesquisa revelou também que, no caso de laudo negativo, não há proposta alguma ${ }^{522}$.

Por outro lado, a pesquisa revelou também que, por causa do mesmo desequilíbrio entre o litigante ocasional e o litigante repetitivo, algumas medidas são desejadas no Cecon: (i) necessidade da presença dos juízes coordenadores dia-a-dia do setor de conciliação, acompanhando a atuação dos conciliadores e dos representantes das partes; (ii) a postura mais ativa do conciliador, afim de suprir o litigante ocasional com informações sobre o caso e sobre o procedimento; (iii) cuidado no relacionamento em razão da convivência com os prepostos dos entes públicos ${ }^{523}$.

\subsection{Falta de identificação do consenso autorizado}

A segunda objeção levantada por Owen Fiss é a frequente ausência de autorização para consentir de quem está presente à mesa.

Segundo o autor, o acordo pressupõe que as partes sejam indivíduos que falam por si mesmos. Contudo, muitas partes que frequentemente vão a juízo defender interesses não são indivíduos, mas organizações e grupos, nas quais não se sabe quem é legitimado para falar por essas entidades e para dar o consentimento do qual muitos acordos dependem. Muitas organizações, como sindicatos e empresas, dispõem de procedimentos formais para identificar as pessoas autorizadas, mas esses processos são imperfeitos, pois são construídos para facilitar as transações entre as organizações e pessoas de fora, mais do que para assegurar que seus membros de fato concordem com as decisões tomadas, além de não eliminarem conflitos de interesses internos. Por exemplo, o presidente de uma companhia pode fazer um acordo para prevenir a abertura de certas práticas gerenciais, mas, por outro lado, a mesma informação pode ser de interesse dos acionistas ${ }^{524}$.

Outro ponto levantado nessa problemática - e aqui é de especial interesse deste trabalho - é que muitos litigantes são órgãos estatais, e os procedimentos existentes nessas

\footnotetext{
${ }^{522}$ ASPERTI, Maria Cecília de Araújo. Meios consensuais de resolução de disputas repetitivas, cit., p. 94 e nota de rodapé n. 263.

${ }^{523}$ ASPERTI, Maria Cecília de Araújo. Meios consensuais de resolução de disputas repetitivas, cit., p. 95 e nota de rodapé n. 264.

${ }^{524}$ FISS, Owen. Against Settlement, cit., p. 1073-1090, p. 1079.
} 
organizações para gerar consentimento autorizado são muito mais incipientes do que nas $\operatorname{organizações~privadas~}^{525}$.

O problema se torna mais pronunciado quando temos em conta que grande parte da litigância atual envolve "entidades sociais nebulosas", grupos como "minorias raciais" ou "residentes de instituições psiquiátricas", que não têm uma estrutura formal e, assim, não dispõem de procedimentos para gerar autoridade para consentir. No caso dos Estados Unidos, as normas de processo civil requerem que o grupo tenha um representante que agirá em seu favor, mas ele recebe tais poderes por meio de um procedimento muito questionável, que é a autonomeação no caso de autor e nomeação pelo adversário no caso de réu ${ }^{526}$.

No Brasil, o problema de identificação do agente autorizado para praticar o ato de consenso dentro dos órgãos públicos é resolvido pelo esquema de competências e de sua delegação já descrito no item 4.1. Apesar de possíveis imprecisões ou conflitos gerados internamente, o sistema existe e garante um mínimo de segurança e higidez do acordo celebrado. Vale retomar a crítica do autor no sentido de que, de fato, muitas vezes o sistema é incipiente e, no caso brasileiro, demanda maior regulação para que o sistema consensual se operacionalize. No mais, como já abordado no item 3.2.1., o fato de o Administrador não se identificar com os titulares dos interesses que ele promove não impede o uso da consensualidade, nem o impede de ser seu representante, desde que tenha a finalidade pública como meta e guia da atuação consensual.

Já no tocante às "entidades sociais nebulosas", a questão parece um pouco mais complexa. O direito brasileiro criou um "microssistema de processo coletivo", em que diversas leis em conjunto (Lei de Ação Civil Pública, da Ação Popular, a Lei do Mandado de Segurança Coletivo, do Código de Defesa do Consumidor e dos Estatutos da Criança e do Adolescente e do Idoso) se subsidiam, criando diferentes instrumentos processuais para a tutela de direitos metaindividuais, atribuindo legitimidade a diferentes entidades para seu uso e, ainda, criando mecanismos consensuais. É no bojo desse sistema que verificamos quem está autorizado a dar consenso sobre um conflito que abranja algum dos interesses sem titular definido (interesses difusos) ou com titulares não identificados, porém identificáveis (interesses coletivos stricto sensu).

Assim, em primeiro lugar, há a necessidade de previsão legal expressa para o legitimado, o que ocorre, por exemplo, no art. $5^{\circ}$ da Lei n. 7.347 (Lei da Ação Civil

${ }^{525}$ FISS, Owen. Against Settlement, cit., p. 1073-1090, p. 1080.
${ }^{526}$ FISS, Owen. Against Settlement, cit., p. 1073-1090, p. 1080. 
Pública). A representatividade adequada, que nos Estados Unidos é aferida pelo juiz, já que a legitimidade é conferida também ao indivíduo, no Brasil é dita como aferível ope legis, pois é a lei que presume a conexão entre o legitimado e o interesse tutelado em alguns casos (como no caso da União, Estados, Municípios, Distrito Federal, Ministério Público e Defensoria Pública) e, em outros, exige comprovação dessa conexão (associações e outros órgãos públicos) ${ }^{527}$.

Como explica Susana Henriques da Costa, não há uma forma expressa de controle pelo juiz de que, no caso concreto, o interesse metaindividual esteja sendo defendido satisfatoriamente. $\mathrm{Na}$ ausência desse controle, o legislador optou por outras saídas para preservar o direito dos interessados nos direitos difusos e coletivos, como a limitação da coisa julgada secundum eventum litis e secundum probationem ${ }^{528}$, em vez de uma coisa julgada de alcance irrestrito. Para a autora, o raciocínio do legislador é no sentido de que não há garantia de que o legitimado seja efetivamente um representante adequado dos interesses que pretende tutelar ${ }^{529}$.

Por outro lado, a autora propõe o controle judicial da representatividade adequada, o que tem sido feito sob a denominação de controle da pertinência temática, que deve existir entre as finalidades institucionais ou estatutárias da entidade legitimada e o interesse que se pretende tutelar, o que serve, inclusive, para o Ministério Público. Por outro lado, a autora vai mais longe ao propor ainda o controle da qualidade da petição inicial, enquanto instrumento apto a deflagrar uma tutela judicial ideal para a crise de direito material envolvida $^{530}$.

De fato, mesmo sendo a representatividade adequada cercada de cautelas, com discussões que buscam aprimorar a correspondência entre o ente legitimado e o interesse

527 COSTA, Susana Henriques da. O controle judicial da representatividade adequada: uma análise dos sistemas norte-americano e brasileiro. SALLES, Carlos Alberto de. As grandes transformações do processo civil brasileiro: homenagem ao Professor Kazuo Watanabe. São Paulo: Quartier Latin, p. 953-978, 2009 , p. 965.

528 "Nesses casos, a coisa julgada ocorrerá se a demanda for julgada (i) procedente ou (ii) improcedente porque ficou comprovado que o fato constitutivo do direito sustentado pelo autor não ocorreu, ou, ainda (iii) improcedente porque foi comprovada a existência de fato impeditivo, extintivo ou modificativo do direito defendido pelo autor. Se a improcedência decorrer de falta de provas, não haverá coisa julgada. É o que prevê o artigo 103, do Código de Defesa do Consumidor" (COSTA, Susana Henriques da. O controle judicial da representatividade adequada: uma análise dos sistemas norte-americano e brasileiro, cit., p. 953-978, 2009, p. 967).

${ }^{529}$ COSTA, Susana Henriques da. O controle judicial da representatividade adequada: uma análise dos sistemas norte-americano e brasileiro, cit., p. 953-978, 2009, p. 968.

${ }^{530}$ COSTA, Susana Henriques da. O controle judicial da representatividade adequada: uma análise dos sistemas norte-americano e brasileiro, cit., p. 953-978, 2009, p. 975. 
em jogo, com o objetivo de maximizar a sua efetiva proteção, ainda assim assim, o instituto não tem o condão de eliminar o risco de uma distorção na representação.

Retornado à crítica de Owen Fiss, o autor reconhece que a litigância não elimina tal risco, pois o caso apresentado pelo representante vai acabar influenciando o julgamento, que vinculará todos os membros da classe da mesma forma que um acordo os vincularia. Por outro lado, o julgamento não exige tanto do representante, pois há uma distância conceitual e normativa entre o que o representante fala e faz e o que a corte decide, porque o juiz testa as afirmações e ações do representante por meio de standards procedimentais e substanciais independentes. A autoridade da decisão vem da lei, não das afirmações do representante, o que permite a vinculação de pessoas não envolvidas no processo ${ }^{531}$.

Ou seja, segundo o autor, a representatividade dessas "entidades nebulosas" estaria mais bem assegurada na adjudicação, já que a decisão viria, no final das contas, da lei, e não das afirmações do representante.

Na solução consensual, o pronunciamento do juiz (que, segundo Fiss, é quem faria atuar a lei) é substituído por um pronunciamento do legitimado em acordo com o causador do dano. Muda-se aquele que emite a solução.

Uma solução proposta por Luciane Moessa de Souza para superar um possível déficit de legitimidade (no sentido não técnico) nesses casos seria a criação de um procedimento de mediação nas ações coletivas que repercutisse na formação do consenso, que possa ser utilizado também no âmbito extrajudicial, com a participação de um terceiro imparcial que domine as técnicas de negociação e possa cumprir a função de identificar pontos comuns e divergências, além de auxiliar na construção de alternativas e na escolha de uma opção viável ${ }^{532}$.

Esse procedimento, a fim de alcançar a legitimidade desejada, poderia contemplar uma forma de participação colaborativa, em que grupos mais fracos, interessados na composição do conflito, pudessem ser incluídos e assistidos para participar dos debates. Nas palavras da autora, "não basta assegurar a participação social, é preciso assegurar a utilização de métodos pelos quais a manifestação das diferentes visões de grupo possa ser canalizada de forma construtiva, a fim de produzir, com clareza de visão, decisões que

\footnotetext{
${ }^{531}$ FISS, Owen. Against Settlement, cit., p. 1073-1090, p. 1080-1081.

${ }^{532}$ SOUZA, Luciane Moessa de. Meios consensuais de solução de conflitos envolvendo entes públicos e a mediação de conflitos coletivos. Tese (doutorado). Centro de Ciências Jurídicas da Universidade Federal de Santa Catarina (UFSC), Florianópolis, 2010, p. 357.
} 
realmente caminhem no sentido de proteger todos os interesses envolvidos"533. Além disso, a mediação envolvendo esse tipo de conflito deve garantir a ampla representatividade dos interesses, de forma que o mediador assegure que cada participante esteja informando devidamente o grupo, órgão ou ente que representa, trazendo inclusive as ponderações feitas por seus representados ${ }^{534}$.

Não é demais ressaltar o instrumento da audiência pública, que é "uma reunião aberta em que a autoridade responsável colhe da comunidade envolvida suas impressões e demandas a respeito de um tema que será objeto de uma decisão administrativa" ${ }^{535}$, já tendo previsão legislativa em inúmeras leis que tratam de decisões administrativas ${ }^{536}$.

No entanto, alerta a supracitada autora que a simples realização de audiências públicas não é suficiente para suprir a legitimidade, se não houver mecanismos de participação efetiva dos grupos sociais afetados na formação da solução final, para que ela não seja um ato meramente formal ${ }^{537}$. Apesar da objeção, a audiência pública pode configurar um instrumento a ser utilizado pelo ente legitimado à tutela coletiva como forma de colher as impressões de grupos sociais afetados pelo conflito e, assim, conferir maior participatividade e legitimidade à solução consensual construída.

\footnotetext{
${ }^{533}$ SOUZA, Luciane Moessa de. Meios consensuais de solução de conflitos envolvendo entes públicos e a mediação de conflitos coletivos, cit., p. 357.

${ }^{534}$ SOUZA, Luciane Moessa de. Meios consensuais de solução de conflitos envolvendo entes públicos e a mediação de conflitos coletivos, cit., p. 411.

535 CABRAL, Antonio. Os efeitos processuais da audiência pública. Revista Eletrônica de Direito Administrativo Econômico. Salvador, IBDP, n. 13, fev./abr. 2008, p. 3.

${ }^{536}$ As audiências públicas vêm previstas, a título exemplificativo, nas seguintes leis: Lei de Licitações (art. 39 da Lei n. 8.666/93), quando o valor da licitação superar em mais de cem vezes o limite previsto pela própria lei, hipótese em que o processo licitatório deverá ser iniciado pela audiência pública; Lei da Anatel (arts. 19, inciso III, da Lei 9.472/97), que disciplina a consulta pública previamente à adoção de medidas sobre serviços públicos de telecomunicação; Lei de Política Energética (art. 19 da Lei n. 9.478/97), que determina a realização de audiência pública sempre que projetos de lei ou alteração administrativa afete direito de agentes econômicos, consumidores ou usuários de bens e serviços das indústrias de petróleo, gás natural e biocombustível; Lei do Processo Administrativo (arts. 31, 32 e 34 da Lei n. 9.784/99), segundo a qual poderá ser aberto período de consulta pública na fase instrutória dos processos administrativos, considerando-se o interesse geral sobre o assunto; Lei da ADI e da ADC (art. $9^{\circ}, \S^{\circ}$ da Lei n. 9.868/99), que permite a oitiva de pessoas com experiência na matéria em debate na ADI, em sendo relevante para a causa; Lei da ADPF (art. $6^{\circ}, \S 1^{\circ}$ da Lei n. 9.882/99), nos exatos termos do procedimento da ADI; a Lei de Responsabilidade Fiscal (art. $9^{\circ}, \S 4^{\circ}$, da Lei Complementar n. 101/2000), para avaliação das metas fiscais quadrimestrais; o Estatuto da Cidade (art. 40, §4º, inciso I, da Lei n. 10.257/2001) prevê a audiência pública como etapa de elaboração do plano diretor; e a Lei de Integração dos Transportes (art. 68 da Lei n. 10.233/2001) também exige a audiência pública sobre projetos de lei, alterações administrativas ou decisões das Diretorias da ANTT e da ANTAQ que afetem direitos de agentes econômicos ou usuários de serviços de transporte.

${ }^{537}$ SOUZA, Luciane Moessa de. Meios consensuais de solução de conflitos envolvendo entes públicos e a mediação de conflitos coletivos, cit., p. 411.
} 
Assim, a crítica de Fiss é procedente, pois chama a atenção para a necessidade de levar em consideração, em conflitos coletivos, que um único legitimado não é, por si só, suficiente para canalizar todos os interessados e afetados pelo conflito.

Por outro lado, como ele mesmo reconhece, esse risco também é existente na via adjudicatória. A crítica não invalida a utilização do meio consensual em detrimento da via adjudicatória, pois existem outros benefícios envolvidos naquela, e também há fortes críticas à legitimidade de uma decisão judicial ${ }^{538}$ que interfere em macroconflitos a partir da representação de um único ente no polo ativo .

\subsection{Falta de fundamento para o envolvimento judicial contínuo}

A terceira objeção levantada por Fiss é que a solução consensual estaria aquém do envolvimento judicial no cumprimento. Para o movimento das ADRs, o julgamento é trivializado como o fim do processo, ou seja, a função jurisdicional terminaria com a declaração do direito, para o quê o acordo seria um perfeito substituto. Contudo, muitas vezes, o envolvimento judicial não termina com o julgamento, mas, pelo contrário, continua indefinidamente, para o quê o acordo não consegue prover uma base adequada e, assim, não ser um perfeito substituto para o julgamento ${ }^{539}$.

$\mathrm{O}$ autor coloca o ponto de que, frequentemente, após o julgamento, as partes retornam ao Judiciário para pedir a revisão do decidido, às vezes por ter ocorrido uma mudança nos fatos, e às vezes porque simplesmente nada mudou, como em divórcios, em que as partes continuam voltando ao Judiciário para conflitos que vão surgindo no desenrolar posterior dos fatos ${ }^{540}$. Outros casos envolvendo reestruturação de organizações

\footnotetext{
${ }^{538}$ Não obstante, o processo civil brasileiro também vem tentando introduzir formas de agregar legitimidade a solução de conflitos multiplexos. Uma das formas de aproximação de terceiros interessados às causas é a previsão do amicus curiae, com disciplina esparsa na lei, que atua por meio de seu interesse institucional sobre determinada matéria - não deixando, portanto, de exercer alguma representatividade, na condição de "porta-voz" da sociedade civil. O único dispositivo legal que faz expressa menção ao amicus curiae é o art. 23, $\S 1^{\circ}$, da Resolução n. 390/2004 do Conselho de Justiça Federal (CJF), mas também há referências à sua atividade no Código de Processo Civil (art. 482, §3º art. 543-A, $\S 6^{\circ}$ e art. 543-C, $\S 4^{\circ}$ ), na Lei da ADI e da ADC (art. $7^{\circ}, \S 2^{\circ}$, da Lei n. 9.868/99), na Lei da Súmula Vinculante (art. $3^{\circ}, \S 2^{\circ}$, da Lei n. 11.417/06), na Lei do CADE (art. 78 da Lei n. 12.529/11) e na Lei dos Juizados Especiais Federais (art. 14, §7º da Lei n. 10.259/01), além do Regimento Interno do Supremo Tribunal Federal (art. 322). O amicus curiae possui natureza jurídica próxima à da assistência, porém com ela não se confunde, sendo considerado um terceiro interveniente distinto das demais figuras litisconsorciais (BUENO, Cassio Scarpinella. Amicus curiae: uma homenagem a Athos Gusmão Carneiro. Texto inédito, disponível em "http://www.scarpinellabueno.com.br/Textos/Athos\%20Gusm\%C3\%A3o\%20CarneiroHomenagem\%20Cassio\%20Scarpinella\%20Bueno.pdf”, p. 1-4.)

${ }^{539}$ FISS, Owen. Against Settlement, cit., p. 1073-1090, p. 1082.

${ }^{540}$ FISS, Owen. Against Settlement, cit., p. 1073-1090, p. 1083.
} 
burocráticas normalmente demandam envolvimento judicial posterior, acompanhando a implementação das decisões ${ }^{541}$.

Há espaço para os acordos mesmo nesses casos. As partes podem não estar cientes das necessidades posteriores ou ainda otimistas em relação ao futuro, mas o inevitável sempre acontece, segundo o autor: as partes retornam ao Judiciário para modificar o acordo, seja para torná-lo mais efetivo ou menos rigoroso; entretanto, Mas o juiz nada mais pode fazer porque não tem via legítima para alterá-lo. Um juiz que se depara com o pedido de desconstituição de um acordo deve reconstruir a situação como ela existiu no momento do acordo, e decidir se a situação de fato mudou o suficiente para basear a modificação do $\operatorname{acordo}^{542}$.

Outro problema é que o acordo impede o devido enforcement, que muitas vezes demanda punição por descumprimento. Mas as cortes relutam em usar sua força para garantir ordens que resultem apenas do consenso, especialmente as que se dirigirem a funcionários públicos de alto escalão. As cortes não veem uma mera barganha entre as partes como motivo suficiente para exercer seus poderes coercitivos ${ }^{543}$.

Por todo o ponto reforçado pelo autor, chega-se à conclusão de que mesmo assumindo que o consenso é dado pela parte livremente e com autoridade para tanto, a barganha é contratual e não contém o tipo de comprometimento com o enforcement já presente no resultado de um julgamento na corte ${ }^{544}$.

$\mathrm{Na}$ esteira dessa crítica, as previsões legais de acordos extrajudiciais têm sido cautelosas em prever que estes assumem a qualidade de "título executivo extrajudicial". Tal é com os termos de ajuste de conduta firmados no âmbito da Lei da Ação Civil Pública, com os termos de compromisso firmados no âmbito da fiscalização pelos órgãos integrantes do SISNAMA (art. 79-A da Lei n. 9.605/98) e dos termos de compromisso firmados no âmbito da Comissão de Valores Imobiliários (art. 11, §7 , da Lei n. 6.385/76).

A Resolução n. 125 do CNJ também se preocupou em manter junto aos CEJUSCs um juiz coordenador, e, se necessário, um adjunto, com funções, entre outras, de homologar os acordos lá realizados para que adquiram força de título executivo judicial (art. $9^{\circ}$ ). Por fim, os projetos de lei elaborados no tema da composição consensual de conflitos também têm tomado esse cuidado.

\footnotetext{
${ }^{541}$ FISS, Owen. Against Settlement, cit., p. 1073-1090, p. 1083.

${ }^{542}$ FISS, Owen. Against Settlement, cit., p. 1073-1090, p. 1083-1084.

${ }^{543}$ FISS, Owen. Against Settlement, cit., p. 1073-1090, p. 1084.

${ }^{544}$ FISS, Owen. Against Settlement, cit., p. 1073-1090, p. 1085.
} 
Tais previsões têm como claro objetivo viabilizar o envolvimento judicial no cumprimento do acordo entabulado, visto que a coerção para observância dos pactos pelas partes ainda é monopólio judicial $^{545}$.

Ademais, existem previsões que abrangem instrumentos não especificados em lei, mas simples acordos que possibilitam que as próprias partes confiram a qualidade de título executivo judicial ou extrajudicial: as partes podem observar as regras de formação dos títulos executivos extrajudiciais, coletando a assinatura de duas testemunhas no instrumento particular (art. 585, inciso II, do CPC); ou ainda, caso queiram que seu acordo receba o mesmo tratamento de uma sentença em termos de enforcement (sobretudo após as alterações procedidas pela Lei n. 11.232/2005, que instituíram um regime mais robusto de cumprimento de sentenças), podem requerer a homologação de "transação" ou "acordo extrajudicial de qualquer natureza", conforme modificações introduzidas pela mesma Lei n. 11.232/2005 $5^{546}$.

Fernanda Tartuce aponta que seria suficiente a constituição de título extrajudicial, mas o legislador teve como motivação incentivar a autocomposição, revelando-a também vantajosa para as partes, e assegurar maior força à transação homologada, conferindo aos acordos maior possibilidade de efetivação pelos reforços inerentes ao novo sistema de execução dos títulos executivos judiciais ${ }^{547}$.

Nesses termos, não procederia, nos dias atuais e no contexto brasileiro, o argumento de Fiss no sentido de que o juiz não julgaria o acordo como suficiente para deflagrar o enforcement judicial. Por outro lado, tais previsões podem ter tido como inspiração justamente as críticas outrora feitas à falta de força dos acordos.

Em termos de possibilidade do envolvimento judicial posterior ao acordo, o direito brasileiro possui instrumentos. O problema é a adequação de instrumentos que possibilitem o efetivo cumprimento da vontade entabulada no acordo.

Em questões envolvendo interesse público e, especificamente, ações concretas de entes públicos, existem dilemas sérios a respeito da adequação do processo como forma de fazer valer tanto as decisões judiciais quanto as composições consensuais.

545 TARTUCE, Fernanda. Lei n. 11.232, art. 475-N, inciso IV: acordo extrajudicial de qualquer natureza homologado em juízo como título executivo judicial. Revista EPD, São Paulo, EPD, v. 3, p. 233-252, 2006, p. 7.

546 TARTUCE, Fernanda. Lei n. 11.232, art. 475-N, inciso IV: acordo extrajudicial de qualquer natureza homologado em juízo como título executivo judicial. Revista EPD, São Paulo, EPD, v. 3, p. 233-252, 2006, p. 7 .

${ }_{547}$ TARTUCE, Fernanda. Lei n. 11.232, art. 475-N, inciso IV: acordo extrajudicial de qualquer natureza homologado em juízo como título executivo judicial, cit., p. 233-252, 2006, p. 10. 
Um caso emblemático relatado em pesquisa coordenada por Luciana Gross Cunha e Daniela Monteiro Gabbay demonstra um pouco das dificuldades do Judiciário em efetivar direitos fundamentais coletivos após os reconhecer. No Estado de São Paulo, o Ministério Público, motivado por uma denúncia de um pai de criança autista, instaurou inquérito civil no qual verificou que o Estado não possuía tratamento e educação específicas para os autistas, mas apenas tratamento psiquiátrico genérico. Após o insucesso em obter um TAC, foi proposta ação civil pública ${ }^{548}$ que teve liminar concedida e, na sequência, foi julgada procedente, nos seguintes termos:

“JULGO PROCEDENTE a ação civil pública movida pelo Ministério Público do Estado de São Paulo contra a Fazenda Pública do Estado de São Paulo, com fundamento no artigo 269, inciso I, do código de Processo Civil, para CONDENÁ-LA, até que, se o quiser, providencie unidades especializadas próprias e gratuitas, nunca as existentes para o tratamento de doentes mentais "comuns", para o tratamento de saúde, educacional e assistencial aos autistas, em regime integral ou parcial especializado para todos os residentes no Estado de São Paulo, a: I - Arcar com as custas integrais do tratamento (internação especializada ou em regime integral ou não), da assistência, da educação e da saúde específicos, ou seja, custear tratamento especializado em entidade adequada não estatal para o cuidado e assistência aos autistas residentes no Estado de São Paulo; II - Por requerimento dos representantes legais ou responsáveis, acompanhado de atestado médico que comprove a situação de autista, endereçado ao Exmo. Secretário de Estado da Saúde e protocolado na sede da Secretaria de Estado da Saúde ou encaminhado por carta com aviso de recebimento, terá o Estado o prazo de trinta (30) dias, a partir da data do protocolo ou do recebimento da arta registrada, conforme o caso, para providenciar, às suas expensas, instituição adequada para o tratamento do autista requerente; III - A instituição indicada ao autista solicitante pelo Estado deverá ser a mais próxima possível de sua residência e de seus familiares, sendo que, porém, no corpo do requerimento poderá constar a instituição de preferência dos responsáveis ou representantes dos autistas, cabendo ao Estado fundamentar inviabilidade da indicação, se for 'o caso, e eleger outra entidade adequada; IV - O regime de tratamento e atenção em período integral ou parcial, sempre especializado, deverá ser especificado por prescrição médica no próprio atestado médico antes mencionado, devendo o Estado providenciar entidade com tais características; V - Após o Estado providenciar a indicação da instituição deverá notificar o responsável pelo autista, fornecendo os dados necessários para o início do tratamento". (grifo da citação original).

Segundo relatado na pesquisa, houve diferentes etapas para o cumprimento da decisão: em um primeiro momento, não havendo entidades públicas específicas, iniciaramse habilitações individuais para que o Governo do Estado custeasse o tratamento ou a mensalidade escolar em instituições particulares; em 2002, a Secretaria de Saúde enfim incluiu o tratamento específico de autistas nos procedimentos do SUS, e as Secretarias de Saúde e Educação passaram a receber administrativamente os requerimentos de pais de autistas, encaminhando-os para instituições privadas especializadas. Ante os altos custos

\footnotetext{
${ }^{548}$ Processo n ${ }^{\circ}$ 0027139-65.2000.8.26.0053, ainda em trâmite perante a $6^{\circ}$ Vara Cível da Fazenda Pública da Comarca de São Paulo.
} 
envolvidos, foi adotada a solução de celebração de convênios com as entidades privadas com fixação de um preço mensal único pago por autista atendido e, por fim, as entidades públicas de ensino passaram a ser equipadas com professores capacitados e grade curricular específica para alunos portadores de deficiências, entre elas o autismo ${ }^{549}$.

Apesar da implementação de medidas administrativas, nos casos em que frustrada a pretensão do representante do autista, as habilitações e execuções individuais continuaram sendo encaminhadas para a $6^{\text {a }}$ Vara da Fazenda Pública, além do fato de que muitos pais de autistas compareciam pessoalmente ao cartório para solicitar providencias em relação a seus filhos em tal nível que o magistrado então responsável pelo processo extinguiu todas as habilitações em curso e impediu novas habilitações, determinando que todas as demandas se processem junto às Secretarias de Saúde e Educação do Estado de São Paulo ${ }^{550}$.

A pesquisa, considerando a decisão contrária ao princípio da inafastabilidade da jurisdição, entendeu, contudo, que ela suscitou importantes questionamentos em relação à capacidade do Judiciário em lidar com a implementação de direitos fundamentais por meio de políticas públicas.

A pesquisa admite o papel importante que o Judiciário teve como ponto de partida do reconhecimento do direito dos autistas ${ }^{551}$. Segundo a pesquisa ${ }^{552}$, entre os obstáculos enfrentados está o próprio envolvimento do Judiciário, que suscitou as seguintes dificuldades: (i) a propositura de inúmeras habilitações e execuções no mesmo juízo sobrecarregou o cartório, sobretudo ante a escassez de funcionários e espaço físico para processar os incidentes; (ii) a falta de expertise dos magistrados para decidir os incidentes, ante a ausência de conhecimento médico para determinar se o habilitante fazia jus ou não ao tratamento ou educação especial; (iii) falta de conhecimento técnico do magistrado para lidar com a gestão do orçamento público, que pode ser um limitador para atender a toda demanda; (iv) a imposição de multa diária, se por um lado pareceu meio coercitivo importante para pressionar o Estado, implicou em gastos maiores com o cumprimento da sentença judicial do que teria com a implementação administrativa; (v) o custeio

${ }^{549}$ CUNHA, Luciana Gross; GABBAY, Daniela Monteiro (coor.). O desenho de sistemas de resolução alternativa de disputas para conflitos de interesse público. Brasília: Secretaria de Assuntos Legislativos do Ministério da Justiça, 2011, p. 23-26.

${ }^{550}$ CUNHA, Luciana Gross; GABBAY, Daniela Monteiro (coor.). O desenho de sistemas de resolução alternativa de disputas para conflitos de interesse público, cit., p. 27-28.

${ }^{551}$ CUNHA, Luciana Gross; GABBAY, Daniela Monteiro (coor.). O desenho de sistemas de resolução alternativa de disputas para conflitos de interesse público, cit., p. 41.

552 CUNHA, Luciana Gross; GABBAY, Daniela Monteiro (coor.). O desenho de sistemas de resolução alternativa de disputas para conflitos de interesse público, cit., p. 48-49. 
desplanejado dos tratamentos em instituições privadas antes de se firmarem os convênios também implicou em gastos desnecessários; (vi) a política pública para autistas acabou burocratizada e engessada pela decisão judicial.

Por outro lado, o gerenciamento da política pública na via administrativa, com o Judiciário exercendo apenas a função de fiscal, se mostrou mais eficaz:

\begin{abstract}
Quando assumida a função de implementar políticas públicas pelo Poder Executivo, a realização do direito dos autistas em obter custeio estatal de tratamento médico e educacional especializado passou a se dar de forma mais célere e menos custosa. Isto porque os autistas são atendidos diretamente pelas Secretarias da Saúde e da Educação e encaminhados a instituições por elas indicadas sem que seja necessário apresentar documentações para processamento pela máquina judiciária, nem pagar as custas exigidas para tanto.

No momento atual de implementação da política pública pela Administração Pública, o Poder Judiciário passou a agir apenas como fiscal, na medida em que pode intervir nos casos em que for inviabilizada ou prejudicada a negociação entre as Secretarias e o responsável por autista.
\end{abstract}

A previsão de multa diária, no caso, incentivou a tentativa de cumprimento espontâneo do julgado, o que nem sempre ocorre - hipótese em que a execução da ordem judicial terá um desdobramento no sentido de execução de obrigação de dar ou de fazer (arts. 461, 461-A, 621 e seguintes do CPC) e, simultaneamente, a execução de quantia para pagamento das astreintes cominadas (na forma da execução de quantia certa contra devedor solvente, art. 646 e seguintes do CPC).

Nesse ponto, emerge como ponto positivo em favor dos meios consensuais o fato de que, por terem, em tese, sido fruto de consenso, os acordos firmados são mais suscetíveis de cumprimento espontâneo pelas partes do que a sentença judicial, a qual é imposta e não leva em consideração o interesse da parte derrotada. Nos acordos de mediação e conciliação, a solução encontrada por ambos e que satisfaz o interesse das partes - na medida do razoável - naturalmente é mais bem recepcionada do que a decisão imposta. .

Ademais, na via consensual, como são as próprias partes que constroem o arranjo da solução, em vez de um terceiro que impõe a decisão (nem sempre se atentando à viabilidade técnica da sua implementação, como visto no caso narrado), a possibilidade da medida vir à realidade pode ser maior ${ }^{553}$.

Rodolfo de Camargo Mancuso aponta, neste específico, que a sentença judicial pode não considerar fatores imponderáveis e, ainda, causar restrições diversas, decorrentes

${ }^{553}$ Cf. TARTUCE, Fernanda. Mediação nos conflitos civis, cit., p. 202. 
da pendência da própria ação judicial, como o atraso de obtenção de recursos captados no mercado financeiro para início da execução do projeto ambiental ${ }^{554}$.

Contudo, prospera a crítica no sentido de que, para que tais assunções efetivamente se verifiquem, é necessário preparo dos envolvidos, inclusive, no caso dos termos de compromisso, do agente público que os toma, bem como a verificação cautelosa das possibilidades e recursos implicados no caso e um sistema de monitoramento eficiente para o acompanhamento do cumprimento do acordo.

\subsection{As ADRs não são capazes de dar uma interpretação oficial da lei e do} direito

A quarta crítica de Fiss diz respeito à necessidade de se dar "uma interpretação oficial da lei e do direito". Segundo o autor, no movimento das ADRs, o acordo aparece como um perfeito substitutivo do julgamento, trivializando o papel da ação judicial e reduzindo sua função social como um simples solucionador de conflitos privados. Assim, o acordo atingiria os mesmos resultados da ação judicial: paz entre as partes, com muito menos custo à sociedade.

Na visão do autor, contudo, a adjudicação tem um escopo mais amplo. É um processo público, em que funcionários públicos (que, nos Estados Unidos, são escolhidos pela via eletiva) possuem um poder que foi definido pela lei pública, não por um acordo privado. Seu trabalho não é garantir a paz ou maximizar interesses privados, mas dar força aos valores presentes em textos como a Constituição e outras leis, interpretá-los e fazê-los reais. Essa função, segundo o autor, não é cumprida quando as partes apenas se compõem.

O acordo retiraria do Judiciário o poder de interpretar a lei pública. Os juízes não podem ir muito além quando confrontados com um acordo em um caso específico. Para o autor,

ser contra o acordo não é urgir que as partes sejam forçadas a litigar, já que isso interferiria em sua autonomia e distorceria o processo de adjudicação; as partes serão inclinadas a fazer a corte acreditar que seu acordo é justiça. Ser contra o acordo é apenas sugerir que, quando as partes se autocompõem, a sociedade ganha menos do que parece, e por um preço que não sabe que está pagando. As partes podem se autocompor enquanto deixam a justiça sem ser feita". Para exemplificar, um acordo em uma

\footnotetext{
${ }^{554}$ MANCUSO, Rodolfo de Camargo. Ação Civil Pública. 13. ed. São Paulo: RT, 2014, p. 280.
} 
demanda contra uma escola pode pacificar as partes, mas não promoverá igualdade $\operatorname{racial}^{555}$.

Desse modo, fazer acordo ria garantir a paz, mas significaria que a parte aceita menos do que o ideal, deixando de se fazer a justiça ${ }^{556}$.

Tratando especificamente da figura do juiz, Fiss afirma que o sentimento de alívio que um juiz tem diante de um acordo não é motivado pelo fato de que o trabalho está feito, ou de que não é necessário trabalho algum porque a justiça foi feita, mas sim um sentimento de que mais um caso "foi para a frente", "andou", o que ocorre sendo ou não feita a justiça. Assim, evita-se a agonia de ter que se tomar uma decisão sobre um caso difícil $^{557}$. Contudo, quando as injustiças afiguram-se gritantes, o valor de se evitar a decisão diminui e a agonia do julgador se faz necessária. Alguém deve confrontar a traição dos ideais mais caros e estar preparado para fazê-los fruir ${ }^{558}$.

Outra questão levantada é que os casos não são iguais. Por exemplo, o caso da dessegregação racial de Los Angeles não é igual aos casos envolvendo conflitos de propriedade ou acidentes de veículo. O primeiro consome mais recursos, afeta mais pessoas e desafia mais o Judiciário. O movimento das ADRs deve se endereçar a esses casos mais "significantes" e demonstrar que pode compô-los adequadamente.

O autor também afirma que uma estratégia de duas vias, em que os casos são separados entre casos que merecem acordo e casos que devem ser adjudicados, pois não é possível formular critérios adequados para separar os casos. Os problemas do acordo não se relacionam tanto com a matéria envolvida, porém mais com questões difíceis de ser apuradas, como a condição financeira das partes, a necessidade de envolvimento judicial, e a necessidade de uma interpretação oficial da lei.

Para o autor, o que o diferencia dos defensores do acordo não é a preocupação com universos diferentes de casos, mas a diferença em sua concepção do Judiciário. Os defensores do acordo concebem-na em termos privados e acreditam que o quê impulsiona os números da litigância é o caráter combativo do povo. $\mathrm{O}$ autor, por outro lado, vê a adjudicação em termos públicos, como um arranjo institucional para que o poder público traga a realidade recalcitrante mais próxima dos ideais escolhidos. As pessoas vão às cortes porque elas precisam delas e não por causa de sua personalidade ${ }^{559}$.

\footnotetext{
${ }^{555}$ FISS, Owen. Against Settlement, cit., p. 1073-1090, p. 1085.

${ }^{556}$ FISS, Owen. Against Settlement, cit., p. 1073-1090, p. 1085.

${ }^{557}$ FISS, Owen. Against Settlement, cit., p. 1073-1090, p. 1086.

${ }^{558}$ FISS, Owen. Against Settlement, cit., p. 1073-1090, p. 1086-1087.

${ }^{559}$ FISS, Owen. Against Settlement., cit.4, p. 1073-1090, p. 1087.
} 
Na mesma linha, Michele Taruffo critica a supervalorização dos meios alternativos de solução de disputas na Europa. Segundo ele, o fenômeno chegou no continente "com atraso" e influenciado pela experiência norte-americana e por ideologias "neoprivatistas", que alimentam e incrementam a desconfiança e a depreciação da Justiça Estatal e, consequentemente, aos instrumentos por ela disponíveis, colocando os meios consensuais e os meios adjudicatórios privados como os mais desejáveis para solucionar conflitos de justiça $^{560}$. A ênfase dada à vantagem dos meios alternativos quanto à não-interferência do Estado nos conflitos enfraqueceria a instância oficial de solução de conflitos e o papel que exerce na interpretação do Direito.

Na perspectiva de valorização dos direitos fundamentais, Michele Taruffo aponta que a mediação apenas seria admissível se a violação a essa espécie de direito tivesse algum aspecto patrimonial a ser negociado, pois é impensável imaginar a disposição, mediante acordo, de algum direito fundamental, como a liberdade ou a saúde ${ }^{561}$.

Por outro lado, as objeções parecem válidas no seguinte sentido: os meios consensuais não podem substituir integralmente a justiça estatal na tutela desses direitos, sob pena de enfraquecer os movimentos de (i) reconhecimento e (ii) efetivação.

No Brasil pós-Constituição de 1988, a função do Judiciário tornou-se de suma importância. Como relatam Oscar Vilhena Vieira e Eloísa Machado de Almeida, a inovação mais importante da Constituição de 1988 foi sua abrangente carta de direitos, que, para além dos direitos civis e políticos, previu uma série de direitos econômicos sociais e culturais, além de conceder direitos especificamente a grupos vulneráveis como idosos, crianças e povos indígenas, e, por outro lado, tem um escopo fortemente ligado à intervenção social do Estado.

Além disso, a CF/88 instituiu um regime em que os direitos fundamentais têm aplicação imediata, superando uma doutrina de direitos econômicos e sociais que eram tidos como dispositivos que não possuíam imediata aplicabilidade por sua condição de “normas programáticas" (art. $5^{\circ}, \S 1^{\circ}$ ), que combinado com a inafastabilidade da jurisdição (art. $5^{\circ}$, inciso $\mathrm{XXXV}$ ), tornou o Poder Judiciário um ator político extremamente importante. De acordo com os autores, "[t]anto ações positivas dos poderes legislativo ou

\footnotetext{
${ }^{560}$ TARUFFO, Michele. Páginas sobre justicia civil (Trad. Maximiliano Aramburo Calle), cit., p. 114.

${ }^{561}$ TARUFFO, Michele. Páginas sobre justicia civil (Trad. Maximiliano Aramburo Calle), cit., p. 116-117.
} 
executivo, quanto a omissão em implementar ou regular tais direitos passaram a poder ser objeto de apreciação pelo Poder Judiciário" ${ }^{\$ 562}$.

Nota-se que, por um lado, Administração Pública é uma das maiores responsáveis pela implementação de políticas públicas de efetivação de direitos fundamentais. Também, por outro lado, tem o poder de polícia, capaz de restringir as liberdades individuais. Com essas competências em mãos, a Administração Pública é agente muito suscetível de violar direitos fundamentais, seja por omissão - deixar de regular, deixar de agir - quanto por ação (adotar medidas desproporcionais).

É inegável o papel do Poder Judiciário que, recebendo demandas judiciais envolvendo a Administração Pública como já explorado no item 3.3.3.1., acaba por identificar omissões dos entes públicos na implementação de direitos fundamentais ou ações que os violem, e atue para adequá-las ao direito, processo no qual acaba interpretando de forma a tornar claro como a Administração deve ser portar em relação a certos cidadãos em certas situações.

Nota-se que do próprio caso dos autistas, relatado no item anterior - e em se colocando de lado as limitações e dificuldades na implementação judicial da política pública -, o reconhecimento do direito dos autistas a tratamento e educação próprias só foi possível pela via judicial, pois a Administração, em fase de inquérito, não manifestou interesse na celebração de um termo de compromisso.

Some-se a isso a existência, no direito brasileiro, de um sistema de direito processual coletivo, com a preocupação voltada para o reconhecimento de direitos não pertencentes a uma pessoa individualmente considerada, mas a grupos diferenciados, em que muitos dos seus instrumentos têm como escopo o controle concentrado de constitucionalidade (ação direta de inconstitucionalidade, ação declaratória de constitucionalidade e ação de descumprimento de preceito fundamental), ou seja, o pronunciamento oficial do Judiciário sobre a conformidade de uma lei ou de ato do Poder Público $^{563}$.

Assim, a advertência de Fiss é importantíssima para se reconhecer que a via adjudicatória deve se manter íntegra para que o Poder Público, se vier a autocompor-se,

\footnotetext{
${ }^{562}$ VIEIRA, Oscar Vilhena; ALMEIDA, Eloísa Machado de. Advocacia estratégica em Direitos Humanos: a experiência do Conectas. Revista Internacional de Direitos Humanos, Sur, n. 15, p. 187-213, dez./2011, p. 190-191.

${ }^{563}$ BUENO, Cássio Scarpinella. Curso Sistematizado de Direito Processual Civil. São Paulo: Saraiva, 2010, v. 2, t. III, p. 197, 203-204.
} 
tenha no Judiciário um padrão de reconhecimento de direitos. Como vimos no item 4.2.1., a atuação do Judiciário é forte indutora de acordos.

Vale destacar, ainda, a defesa da atuação do Judiciário como um desejado poder contramajoritário, no sentido de proteção de minorias. Como escreve Fernanda Tartuce, em todas as sociedades existem minorias étnicas, religiosas, sexuais e econômicas que possuem pouca ou nenhuma representação nos órgãos legislativos e estão à margem do processo democrático. Diante dos objetivos fundamentais da República de erradicação da pobreza e da marginalização, bem como da promoção do bem a todos sem qualquer forma de discriminação (art. $3^{\circ}$ da Constituição Federal), aliado ao princípio da isonomia em seu aspecto material, legitima-se a tutela das minorias e a atuação do Judiciário quando houver negativas à sua observância voluntária ${ }^{564}$.

Ainda é preciso ter em conta que, apesar do avanço no reconhecimento de direitos, a Constituição de 1988 não contemplou expressamente questões ligadas a direitos de minorias, tais como a união civil homoafetiva e direitos reprodutivos ${ }^{565}$.

Desse modo, o Poder Judiciário está habilitado e cumpre funções constitucionais tanto no sentido de dar a necessária interpretação oficial à lei como de resguardar direitos de grupos vulneráveis, processos nos quais acaba suprindo omissões ou desfazendo iniquidades praticadas pelos outros Poderes. Por isso, mesmo dentro de uma visão revisitada do acesso à justiça, defende-se a função do Poder Judiciário como limitador de políticas públicas que ofendam valores legais.

Por exemplo, se as demandas envolvendo pretensões decorrentes de união entre pessoas do mesmo sexo fossem majoritariamente encerradas com o acordo, e existindo resistência legislativa em regular o tema, provavelmente os Tribunais Superiores não teriam desenvolvido, no mesmo passo, uma jurisprudência favorável que culminou em um julgamento que reconheceu às uniões entre pessoas do mesmo sexo a aplicação de todas as regras da união estável, vedando qualquer interpretação da regra do art. 1.723 do Código Civil em sentido discriminatório e excluindo qualquer interpretação que impeça o reconhecimento de união entre pessoas do mesmo sexo ${ }^{566}$. Na sequência, o julgamento

\footnotetext{
${ }^{564}$ TARTUCE, Fernanda. Igualdade e vulnerabilidade no processo civil, cit., p. 62-64.

565 VIEIRA, Oscar Vilhena; ALMEIDA, Eloísa Machado de. Advocacia estratégica em Direitos Humanos: a experiência do Conectas, cit., p. 191.

566 Cf. BRASIL. Supremo Tribunal Federal. Ação direta de inconstitucionalidade n. 4277-DF. Órgão Julgador: Tribunal Pleno. Relator: Min. Ayres Britto. J. em: 05/05/2011. DJ em: 14/10/2011; BRASIL. Supremo Tribunal Federal. Ação de Descumprimento de Preceito Fundamental n. 132-RJ. Órgão Julgador: Tribunal Pleno. Relator: Min. Ayres Britto. J. em: 05/05/2011. DJ em: 14/10/2011.
} 
derivou a Resolução n. 175/2013 do CNJ, que obrigou todos os cartórios do Brasil a realizar a celebração de casamento civil entre pessoas do mesmo sexo.

Em conclusão, é bastante pertinente, na crítica de Fiss, que o uso sistemático dos meios consensuais não iniba que demandas sociais sejam filtradas e obscurecidas por não ganhar visibilidade no Judiciário, enfraquecendo embates necessários para o progresso do reconhecimento de direitos; o que demanda uma postura crítica daqueles que exercem funções de defesa de interesses sociais (como o Ministério Público e Defensoria Pública) e no comportamento do próprio Poder Judiciário, além da articulação de grupos sociais, na dosagem de matérias nas quais necessário um pronunciamento judicial mesmo que possível a composição consensual.

O que se sustenta, por outro lado, é um sistema de convivência das práticas, com atenção para que, em casos que envolvam a Administração Pública, a litigância não seja a única alternativa adotada pela advocacia pública, sobretudo em matérias que vêm se sedimentando nos tribunais ou em questões em que viável o reconhecimento de plano do interesse público, sem a necessidade de decisão judicial.

\subsection{O inabalável critério numérico e a perda de qualidade do processo e de seu} resultado

No contexto reformista de tentativa de reforma do Judiciário, foi dada especial atenção aos meios consensuais. Como afirmam Fernanda Tartuce e Érica Barbosa Silva, a forma de promoção de justiça passa a se dar, sobretudo, quanto como resposta ao número de demandas judiciais que a às quais se deu solução, sendo dado frequente o enfoque quantitativo em detrimento ao enfoque qualitativo. A conciliação judicial tem sido alvo, especialmente, de pesado investimento, sob a crença de que a Justiça poderá atuar melhor se mais causas forem extintas por acordos celebrados em sessões de conciliação ${ }^{567}$.

Neste tocante, pode-se fazer um paralelo com a crítica tecida por Michele Taruffo, que se mostra cético com a forma como os meios alternativos de solução de disputas foram apresentados, na Europa, como uma solução aos problemas de ineficiência do Judiciário. A análise do autor italiano é focada especialmente em um aspecto: a forma como são

${ }^{567}$ SILVA, Érica Barbosa e; TARTUCE, Fernanda. A conciliação diante da política judiciária de tratamento adequado de conflitos. In: TUCCI, José Rogério Cruz e; RODRIGUES, Walter Piva; AMADEO, Rodolfo da Costa Manso Real. (Org.). Processo Civil: Homenagem a José Ignacio Botelho De Mesquita. 1ed.São Paulo: Quartier Latin, 2013, p. 60-78, p. 62-63. 
desenvolvidos os meios alternativos, sobretudo os consensuais, com foco primordial na prevenção ou extinção de demandas, acaba por entregar uma justiça pior que aquela já entregue pela via judicial tradicional ${ }^{568}$.

Para o autor, apesar de haverem também razões culturais e ideológicas (neoprivatismo) para o fomento aos meios alternativos de solução de conflitos nas sociedades ocidentais (que não têm a mesma tradição de sociedades como a chinesa ou japonesa), o principal motivo que levou os legisladores ocidentais a investir nos meios alternativos, especialmente os italianos na visão do autor, foi a crise profunda da justiça estatal; como esta não funciona adequadamente, o legislador tende a desviar o maior número possível de casos para fora dos canais judiciais, aliviando a carga de trabalho dos juízes e permitindo que as partes encontrem alguma solução. Assim, é um movimento motivado primordialmente pela ineficiência do Judiciário ${ }^{569}$.

De fato, o histórico do desenvolvimento das ADRs nos Estados Unidos e a promoção que atualmente vem sendo feita no Brasil mostram que as observações do autor não estão equivocadas.

Mas quais as repercussões de tal motivação? Para o autor, os meios consensuais só são uma efetiva alternativa à solução judicial se puderem tutelar direitos adequadamente. No entanto, tais meios confiam na disposição da parte em encontrar um acordo que normalmente não dará completa razão aos titulares de um direito. Deste modo, não se poderia dizer que os meios consensuais são uma forma de "fazer justiça", mas sim de simplesmente compor interesses ${ }^{570}$.

Érica Barbosa e Silva e Fernanda Tartuce confirmam essas impressões, ao relatarem que, na prática da conciliação no Judiciário brasileiro, a ausência de técnica dos conciliadores muitas vezes resulta em pressão para que as partes celebrem acordos insensatos, baseados em renúncia de parte dos interesses em jogo. Ademais, o incentivo excessivo desses meios pode fomentar algumas mensagens errôneas sobre o Judiciário: "por que pagar imediatamente o que se deve se protelar e remeter o processo à Justiça fará com que se pague menos (pela insistência de fomentar acordos quaisquer sejam eles)?" 571.

Por tal motivo, advertem as autoras sobre o risco de uso errôneo dos meios consensuais, cuja prática não se justificaria pela dificuldade da prestação jurisdicional nos

\footnotetext{
${ }^{568}$ Cf. TARUFFO, Michele. Páginas sobre justicia civil (Trad. Maximiliano Aramburo Calle), cit., p. 114.

${ }^{569}$ TARUFFO, Michele. Páginas sobre justicia civil (Trad. Maximiliano Aramburo Calle), cit., p. 115-116.

${ }^{570}$ TARUFFO, Michele. Páginas sobre justicia civil (Trad. Maximiliano Aramburo Calle), cit., p. 116-117.

${ }^{571}$ SILVA, Érica Barbosa e; TARTUCE, Fernanda. A conciliação diante da política judiciária de tratamento adequado de conflitos, cit., p. 60-78, p. 67.
} 
moldes adjudicatórios ${ }^{572}$. Caso se revele ser a solução judicial a mais adequada na hipótese, ela há de ser adotada, não se justificando a realização de uma transação apenas por questões estruturais de dificuldade na prestação jurisdicional. ${ }^{573}$.

Tais observações são particularmente relevantes no âmbito da utilização dos meios consensuais pela Administração Pública: a via consensual deveria apresentar-se como uma alternativa ao sistema de justiça estatal se garantir uma tutela adequada de direitos. Não pode a Administração utilizar a via consensual como um sistema para a violação de direitos, como por vezes se apontou ser o caso nas conciliações previdenciárias.

Essa concepção quantitativa acaba sendo transportada para a avaliação do "sucesso" da utilização do meio consensual.

Sobre o tema, a avaliação de uma prática de solução de conflitos pode se dar sobre o enfoque da simples eficiência, que busca o maior número de conflitos, resolvido no menor tempo com o menor dispêndio de custos. Outro enfoque é o da eficácia da solução do conflito, que é uma via bem mais subjetiva e de difícil avaliação, sobre cujos critérios pode haver séria divergência: seria critério a satisfação das partes? A efetiva eliminação do conflito? O percentual de cumprimento espontâneo? Ao menos, esse critério se relaciona mais com a retórica do elogio aos meios consensuais, enquanto preconizados como meios adequados de tratamento de conflitos.

Segundo Maria Cecília de Araújo Asperti, a avaliação é de suma importância para que se atinjam as finalidades de um sistema ou um programa de meios consensuais, e necessita de uma clareza em relação aos critérios a serem adotados ${ }^{574}$. No entanto, na pesquisa realizada em cinco diferentes programas no Brasil e nove programas nos Estados Unidos, a autora verificou que as avaliações eram, em sua maioria, baseadas apenas em critérios de eficiência (quantitativos): número de audiências realizadas, índice de comparecimento das partes, acordos firmados, valores envolvidos etc., não obstante os objetivos declarados dos programas sejam o tratamento adequado dos conflitos e a preservação do relacionamento entre as partes $^{575}$.

A autora relata, por outro lado, exceções em que foram adotados critérios ligados à qualidade dos acordos: a avaliação realizada pela CECON-SP (Justiça Federal), pelo

\footnotetext{
${ }^{572}$ SILVA, Érica Barbosa e; TARTUCE, Fernanda. A conciliação diante da política judiciária de tratamento adequado de conflitos, cit., p. 60-78, p. 69.

${ }^{573}$ SILVA, Érica Barbosa e; TARTUCE, Fernanda. A conciliação diante da política judiciária de tratamento adequado de conflitos, cit., p. 60-78, p. 70.

${ }^{574}$ ASPERTI, Maria Cecília de Araújo. Meios consensuais de resolução de disputas repetitivas, cit., p. 155.

${ }^{575}$ ASPERTI, Maria Cecília de Araújo. Meios consensuais de resolução de disputas repetitivas, cit., p. 74.
} 
CEJUSC-Brasília e pelo CEJUSC-JEC de Brasília avaliam a satisfação das partes e advogados quanto à atuação dos mediadores/conciliadores, com a condução do procedimento e com os resultados obtidos. Em Brasília, segundo a autora, também é avaliada a satisfação das partes quanto à atuação dos prepostos dos litigantes habituais, "o que permite ao Judiciário que intervenha junto a estes entes caso seus prepostos não estejam adotando posturas colaborativas nas sessões de conciliação e mediação"576.

De fato, a avaliação qualitativa posiciona mais dificuldades para ser realizada. Para Paulo Eduardo Alves da Silva, definir se uma mediação ou conciliação foi feita com qualidade é uma pergunta muito complexa e para ela não há respostas precisas. Contudo, há a certeza de que não é critério para avaliar a qualidade da redução de processos do estoque do Judiciário, o que contribui apenas para o gerenciamento dos órgãos judiciários, mas não da Justiça. Segundo o autor, "os dados quantitativos revelam pouco sobre a qualidade de justiça, cuja mensuração é bem mais complexa e só se pode atingir por dados indiretos. A justiça e, via de consequência, o consenso são valores de natureza qualitativa, não quantitativa" 577 .

Segundo o autor, os indicadores qualitativos são mais capazes de revelar a produção de justiça pelos meios consensuais. Assim, mais valem acordos bem feitos do que muitos acordos realizados em escala. E bem feitos a partir de quê? Segundo o autor, há quatro possibilidades para os meios de solução de conflitos: (i) aplicação da lei no caso concreto, (ii) resolução do conflito com paz social, (iii) eliminar o processo e a lide e (iv) satisfazer as partes.

Nos meios adjudicatórios tradicionais, a aplicação da lei é o critério mais adequado para avaliação da qualidade da decisão, e também condizente com o Estado de Direito e um sistema de tripartição dos poderes, remetendo a um padrão legítimo democraticamente. Há justiça porque há lei. Contudo, outro critério se posiciona como qualitativo para apurar a distribuição de justiça, qual seja a satisfação das partes. Esse critério é particularmente interessante quando tratamos de meios consensuais em geral, em que a solução não está adstrita à melhor solução de acordo com a interpretação da lei, mas que é de livre construção do conteúdo pelas partes.

Em determinados casos, prospera uma observação feita pelo autor a esse respeito:

\footnotetext{
${ }^{576}$ ASPERTI, Maria Cecília de Araújo. Meios consensuais de resolução de disputas repetitivas, cit., p. 74, nota de rodapé n. 399.

${ }^{577}$ SILVA, Paulo Eduardo Alves da. Mediação e conciliação, produtividade e qualidade, cit., p. 40-47, p. 4546.
} 
Uma dada solução, mesmo que não seja a solução dada pela lei, pode angariar a simpatia das partes. Do ponto de vista particular, isso bastaria para se entender que fora produzida justiça. Mas conclusão não é assim tão simples, pois os sistemas jurídico e político trabalham com o padrão legal e, uma vez que a resolução de conflitos foi institucionalizada pelos canais do Estado, espera-se não apenas uma solução satisfatória para as partes, mas toda a sociedade ${ }^{578}$.

Esse apontamento soa relevante para se definir critérios qualitativos para avaliação da utilização de um meio consensual pela Administração Pública: se é o próprio Estado que está se submetendo ao meio consensual, com obrigação de observância dos parâmetros legais em qualquer acordo firmado (vide item 4.2), a aplicação da lei no caso concreto não seria um critério adequado de avaliação da qualidade do acordo?

Uma avaliação adequada deve partir de critérios que correspondam aos objetivos da solução consensual.

Assim, o critério quantitativo em si não é de todo descartado se os objetivos são igualmente quantitativos: desta maneira, se temporariamente é lançado um programa de parcelamento com o objetivo de aumentar a arrecadação e diminuir o estoque de dívidas fiscais, não haveria problema em se adotar o critério do volume negociado e do volume efetivamente arrecadado, sendo este, inclusive, um monitoramento necessário e responsável.

Por outro lado, um programa de conciliação previdenciária, que tenha como objetivo abreviar o tempo de processo e, assim, realizar economia em juros, correção monetária e recursos humanos, tem de ter em visto, do outro lado, o cuidado com o segurado, e toda a ação da política previdenciária também deve ter o atendimento de direitos e a aproximação do cidadão como meta, de forma que é necessário ir além da avaliação por número de acordos feitos e buscar identificar o cumprimento da lei, bem como o atendimento do direito do segurado, inclusive para fins de controle e ajustes em favor da parte vulnerável.

Por fim, toda ação administrativa consensual tem, ou deveria ter, no fundo, o objetivo de estabelecer uma administração mais paritária, de aproximar o cidadão e legitimar o Estado perante ele, buscando mitigar a conhecida desconfiança no Poder Público. Assim, critérios qualitativos como a satisfação das partes e advogados quanto à atuação do terceiro imparcial e, especialmente, com a atuação do representante da Administração parecem ser adequadas para esses casos.

${ }^{578}$ SILVA, Paulo Eduardo Alves da. Mediação e conciliação, produtividade e qualidade, cit., p. 40-47, p. 46. 
Em resumo, a crítica que se faz é que o desenvolvimento de uma cultura de solução consensual de conflitos não pode se pautar em critérios apenas de número de processos judiciais ou de demandas extintas. Como bem pontua Maria Cecília de Araújo Asperti,

Se as repercussões dessas disputas e a análise perfunctória das causas de contingente de disputas repetitivas (litigância) forem relegadas em prol de uma busca unicamente por efetividade, celeridade e informalismo, o Judiciário estará de fato privilegiando uma justiça de segunda classe, em detrimento de seu dever de prestação jurisdicional assegurado constitucionalmente e de um acesso à justiça efetivo à população ${ }^{579}$.

${ }^{579}$ ASPERTI, Maria Cecília de Araújo. Meios consensuais de resolução de disputas repetitivas, cit., p. 74. 


\section{Parte III - Pesquisa realizada na Procuradoria-Geral do Município de São Paulo}

\section{RELATO E ANÁLISE.}

\subsection{Objeto do estudo e metodologia}

Cremos que a terceira questão colocada por este trabalho ("A Administração Pública, em sua atuação concreta, lança mão de meios consensuais de solução de conflitos? Ou os encaminha exclusivamente ao Judiciário? Quais os razões para uma ou outra conduta?”) não pode ser respondida com qualidade a partir apenas de revisão bibliográfica sobre o tema - até por não ser uma pergunta "dogmática", não coloca uma indagação descritiva $^{580}$ ou prescritiva a respeito de um conjunto normativo. A resposta a tal pergunta apenas pode ser dada com qualidade a partir de dados da realidade.

Por isso, este capítulo procura apresentar uma pesquisa empírica que investiga os pontos levantados. Contudo, ela há de ser delimitada, pois a realidade da Administração Pública é complexa demais para ser toda abarcada por uma pesquisa individual em dissertação de mestrado.

O problema da generalização é que a Administração Pública não é una. Envolve inúmeras pessoas jurídicas de Direito Público, em três níveis federativos diversos (União, Estados e Municípios), além da administração indireta ${ }^{581}$. Não é plausível pressupor que o comportamento da União em relação aos meios consensuais é o mesmo do que o de um

\footnotetext{
${ }^{580}$ Nota metodológica: a pesquisa eminentemente descritiva em Direito tem sido criticada por ser simples reconstrução de informações já existentes em doutrina, lei e jurisprudência (conceitos e interpretações de normas), pois pouco agregariam ao conhecimento científico. Caio Mario da Silva Pereira Neto e Paulo Todescan Lessa Matos assim descrevem a massiva pesquisa descritiva em Direito: "(i) trabalhos de reconstrução doutrinária sobre conceitos descritivos de normas e sistemas normativos (em geral com a apresentação do posicionamento de diversos autores sobre cada conceito), (ii) descrição legislativa (apresentação do quadro normativo formado pelas constituições federal e estaduais, leis e regulamentos) e (iii) descrição de julgados (decisões judiciais ou administrativas que afirmam posicionamentos sobre a aplicação do quadro normativo)" (PEREIRA NETO, Caio Mario da Silva; MATOS, Paulo Todescan Lessa. A crise da pesquisa em direito no Brasil: Armadilhas e alternativas ao formalismo jurídico. Disponível em: <http://www.law.yale.edu/documents/pdf/sela/CaiodaSilvaPereiraandPauloTodescanLessaMattos Portugue se.pdf>. Acesso em: 12 set. 2013.

581 Vide nota de rodapé 1: adotamos aqui o termo "Administração Pública" em sentido mais estrito, abrangendo apenas entes públicos que exercem função administrativa e que estejam submetidos ao regime público, excluindo-se, assim, agentes particulares, empresas públicas e sociedades de economia mista.
} 
Município do interior paulista, por exemplo. Também é impossível no âmbito do presente trabalho investigar cada unidade da Administração Pública.

Outro problema é que a atuação da Administração se dá em diferentes níveis hierárquicos e funcionais. Pode ocorrer que o setor de recursos humanos de um hospital público resolva informal e consensualmente uma questão envolvendo dano à imagem de um de seus servidores. Situação diferente seria a discussão de um contrato de prestação de serviços pela assessoria jurídica desse mesmo hospital.

Por tais motivos, a busca de uma resposta de maior qualidade e precisão, ainda que de alcance limitado, impõe que se restrinja a parcela da Administração Pública e de sua atuação cujo comportamento se estudará.

Assim, a opção de recorte do presente trabalho é restringir o estudo da seguinte forma:

- A pessoa jurídica de direito público escolhida é o Município de São Paulo, devido à proximidade do pesquisador às fontes de pesquisa como documentos e atores;

- O nível escolhido é a Procuradoria-Geral do Município de São Paulo (PGM-SP), pois nela se concentram os casos antes de seu encaminhamento ao Poder Judiciário. Além disso, na Procuradoria estão concentradas as competências de representação judicial e extrajudicial do Município e no trato de assuntos jurídicos, inclusive "[p]ropor ao Prefeito ou a outra autoridade municipal competente as medidas que se afigurem convenientes à defesa dos interesses do Município ou à melhoria do serviço público municipal, especialmente nas áreas conexas à sua esfera de atribuições" (art. $2^{\circ}$, inciso VIII, da Lei Municipal n. 10.182/86) Dentro do presente trabalho, que trata a questão a partir da perspectiva da opção pela via consensual ou judicial, a princípio faz mais sentido a investigação da função onde se concentra tal opção.

Naturalmente, a Administração Pública tem frentes absolutamente diferentes de atuação e se envolve em relações jurídicas de natureza distintas que se submetem a regras próprias: servidores públicos, relações tributárias, contratos públicos, responsabilidade civil extracontratual, prestação de serviços públicos, etc. Toda essa gama de relações pode desembocar no Judiciário e, a princípio, poderia ser objeto de estudo do presente trabalho $^{582}$.

${ }^{582}$ Há trabalhos que se propõem a analisar a questão da possibilidade de conciliação a partir da cada tipo de “causa". Assim é o artigo de Elon Kaleb Ribas Volpi (Conciliação na Justiça Federal: A indisponibilidade do interesse público e a questão da isonomia. Revista da PGFN, Brasília, PGFN, ano 1, n. 2, p. 139-164, jul./dez. 2011). 
Contudo, optou-se neste trabalho, a princípio, por não se fazer uma restrição em relação à matéria, porque a pesquisa bibliográfica revelou que, a princípio, todas as áreas são passíveis de soluções com algum grau de consensualidade, apenas estando mais ou menos condicionadas. Ademais, notou-se ao longo da pesquisa que, sendo o uso de meios consensuais reduzido na Administração Pública, seria mais útil analisar todas as diferentes manifestações de consensualidade institucionalizadas em um único órgão, a fim de traçar linhas comuns de óbices e dificuldades.

O método utilizado será o estudo de caso, que nada mais é que o estudo de "qualquer situação concreta a partir da qual se possa analisar um determinado questionamento" ${ }^{, 583}$.

$\mathrm{O}$ estudo de caso se revela como o método mais adequado para a indagação aqui formulada, pois, como explica José Garcez Ghirardi e outros, o método apresenta muitos diferenciais positivos: permite a aproximação entre a teoria e o plano concreto de prática do direito; viabiliza reflexões aprofundadas sobre questões jurídicas, orientadas por uma situação concreta; possibilita descobertas que não seriam identificáveis senão por meio de estudo de caso; permite reconhecer a dinâmica prática de algum aspecto do direito, o que leva a considerações, inclusive, sobre a própria teoria do direito; permite enfrentar questões interdisciplinares do direito e multidisciplinares que advêm de outras ciências ${ }^{584}$.

O tema do tratamento consensual de conflitos não pode ser analisado apenas sob o prisma da dogmática, considerando apenas as normas postas. Razões para utilização ou não dos meios consensuais pela Administração não estão apenas no embate de ideias entre doutrinadores ou nas diversas camadas interpretativas das normas. Estão também no caldo de cultura formado por quem opera o direito envolvendo a Administração, na sua interpretação específica sobre as normas, as dificuldades a as vantagens que enxergam nos referidos meios. Conhecer a realidade dos atores que lidam com o tema e da sua atuação é importante para identificar questões ocultas ou que não são levadas em conta pelos textos doutrinários e, inclusive, possibilitando verificar se a doutrina não está se debruçando sobre questões que, na prática, não são os pontos nevrálgicos.

\footnotetext{
583 GHIRARDI, José Garcez; PALMA, Juliana Bonacorsi de; VIANA, Manuela Trindade. Posso fazer um trabalho inteiro sobre um caso específico? QUEIROZ, Rafael Mafei Rabelo; FEFERBAUM, Marina (coord.). Metodologia jurídica: um roteiro prático para trabalhos de conclusão de curso. São Paulo: Saraiva, 2012, p. 175-190, p. 178.

${ }^{584}$ GHIRARDI, José Garcez; PALMA, Juliana Bonacorsi de; VIANA, Manuela Trindade. Posso fazer um trabalho inteiro sobre um caso específico?, p. 181.
} 
Para tanto, foram realizadas entrevistas com atores-chave dentro da Procuradoria, com a finalidade tanto de (i) obter mais informações sobre a resolução consensual de conflitos e seus possíveis entraves (dados), quanto de (ii) recolher a percepção dos atores sobre o tema. As entrevistas foram seguidas da pesquisa dos documentos relacionados às práticas consensuais mencionadas.

A pesquisa foi qualitativa e contemplou a realização de oito entrevistas, seis delas no âmbito da PGM e duas no Juizado da Fazenda Pública Estadual do Fórum Hely Lopes Meirelles (São Paulo-SP), no período entre maio e dezembro de 2014. A escolha dos entrevistados foi feita por indicações de profissionais no tema. Conforme as entrevistas se realizavam, novas indicações eram feitas de acordo com a proximidade dos indicados com o tema de interesse do trabalho. A pedido de alguns entrevistados, sua identidade será preservada e as falas não serão identificadas.

As entrevistas no Juizado não estavam no planejamento inicial, mas notou-se a necessidade de verificar junto ao Judiciário o motivo do baixo grau de uso da conciliação judicial, extraído das entrevistas realizadas na PGM.

As entrevistas na PGM-SP foram mistas entre abertas e semiestruturadas. Elaborouse um roteiro de entrevista inicial (apêndice 1), mas conforme as respostas do entrevistado, as perguntas foram reorganizadas ou adequadas, e outras foram acrescentadas. Já as entrevistas no Juizado Especial da Fazenda Pública foram abertas.

O presente capítulo se divide em quatro partes: (i) a primeira apresenta brevemente a estrutura e as competências da PGM-SP; (ii) a segunda relata as práticas consensuais identificadas ao longo da pesquisa; (iii) a terceira reúne as percepções dos entrevistados sobre os meios consensuais e suas limitações no uso pela Administração; (iv) a quarta procura responder às perguntas realizadas na proposta da dissertação.

\subsection{Estrutura e competências}

A Procuradoria-Geral do Município de São Paulo é órgão ligado à Secretaria Municipal de Negócios Jurídicos (SJ), cuja estrutura básica atual foi dada pela Lei Municipal n. 10.182, de 30 de outubro de 1986. Desde sua entrada em vigor, houve alterações relevantes em sua estrutura promovidas pelo Decreto n. 51.821/2010 - que alterou a denominação do "Departamento Patrimonial” para "Departamento de Defesa do 
Meio Ambiente e do Patrimônio" - e pelo Decreto n. 53.798/2013, que subordinou a Procuradoria da Fazenda Municipal à Procuradoria-Geral do Município.

Houve, posteriormente, a criação de Coordenadorias com competências específicas e outros órgãos submetidos diretamente à Procuradoria-Geral do Município. Atualmente, a estrutura da SJ e da PGM-SP segue o seguinte organograma:

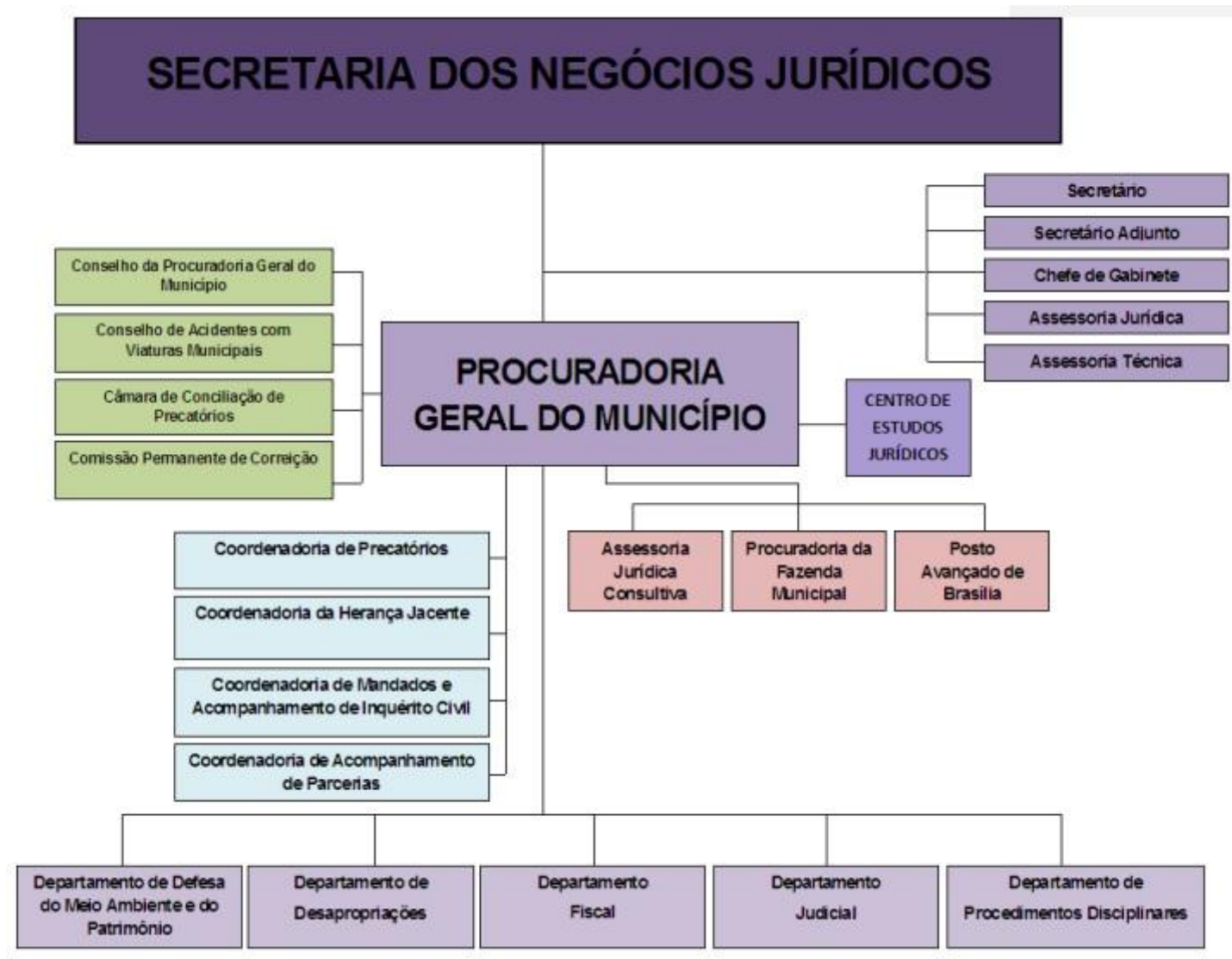

Figura 1: Organograma da Secretaria Municipal de Negócios Jurídicos e da Procuradoria-Geral do Município de São Paulo. Disponível em: http://www.prefeitura.sp.gov.br/cidade/secretarias/negocios_juridicos/organizacao/estrutura/index.php?p=31 9>

A implementação da PGM-SP, contudo, ficou condicionada pela Lei n. 10.182/86 a Decreto do Executivo (art. 27). Assim, a organização e as competências da SJ e da PGMSP foram consolidadas no Decreto n. 27.321/1988, que estipulou o seguinte:

Art. $3^{\circ}$. Compete à Secretaria dos Negócios Jurídicos, por intermédio da ProcuradoriaGeral do Município - PGM:

I - representar judicial e extrajudicialmente o Município;

II - representar a Fazenda Municipal junto ao Tribunal de Contas do Município - TCM;

III - promover, privativamente, a cobrança amigável ou judicial da Dívida Ativa;

IV - exercer funções jurídico-consultivas atinentes à esfera do Executivo e da Administração Municipal em geral; 
$\mathrm{V}$ - processar sindicâncias, inquéritos administrativos e demais procedimentos disciplinares;

VI - zelar pelo estrito cumprimento da legislação concernente ao Município, representando ao Prefeito ou a outra autoridade Municipal competente nos casos em que se fizer necessário;

VII - propor ao Prefeito ou a outra autoridade municipal competente as medidas que se afigurarem convenientes à defesa dos interesses do Município ou à melhoria do serviço público municipal, especialmente nas áreas conexas à sua esfera de atribuições, por intermédio do titular da Pasta;

VIII - representar o Município ou o Prefeito, por si ou por quem designar, ouvida o Secretário dos Negócios Jurídicos, nas assembleias das entidades da Administração Indireta;

IX - desempenhar outras atribuições compatíveis com a natureza de suas funções (grifos nossos).

Ao Procurador-Geral do Município ficaram atribuídas as seguintes competências de interesse do presente trabalho:

Art. $7^{\circ}$. Compete ao Procurador-Geral do Município:

I - orientar e superintender os serviços jurídicos e administrativos da ProcuradoriaGeral;

II - propor ao Secretário dos Negócios Jurídicos a declaração de nulidade de atos da Administração Centralizada e Descentralizada;

III - receber citações e demais atos de comunicação oriundos de ações onde figure a Fazenda Municipal, podendo delegar estas atribuições;

(...)

VI - confessar, desistir, transigir, firmar compromissos e reconhecer pedidos nas ações de interesse da Fazenda Municipal, podendo delegar estas atribuições;

(...)

XIII - dirigir ao Secretário dos Negócios Jurídicos pedido de aprovação das simulas de jurisprudência administrativa;

(...)

XV - submeter à apreciação do Secretário dos Negócios Jurídicos proposta de edição de decisão normativa sobre matéria sugerida pelos Procuradores-Diretores de cada Departamento e pelo Procurador Assessor-Chefe da Assessoria Jurídico-Consultiva; (...)

XVII - decidir sobre a inclusão de débito no rol das cobranças inviáveis, mediante pronunciamento fundamentado, quando o prosseguimento das diligências se afigure antieconômico, podendo, se necessário, delegar essa atribuição;

XVIII - outras atribuições compatíveis com o cargo, quando cometidas pelo Prefeito ou peio Secretário dos Negócios Jurídicos, por solicitação de órgãos interessados (grifo nosso).

Como visto, a competência para transigir e firmar acordos nas ações de interesse da Fazenda Municipal ficou concentrada no Procurador-Geral, sem limite de valor aparentemente. O mesmo diploma legal, posteriormente aprimorado pelo Decreto n. 34.050/1994, delegou tal competência de acordo com faixas de valores envolvidos ou matéria. Assim, destacam-se as seguintes previsões (grifos nossos):

Art. 48 Aos Diretores dos Departamentos Judicial, Fiscal e de Desapropriações, nas áreas de suas respectivas competências, ficam delegadas as seguintes atribuições: 
II - confessar, desistir, transigir, firmar acordos e reconhecer pedidos em acões de valor de até 100 (cem) UFM;

III - decidir sobre a não interposição de recursos e não impugnação de embargos; IV - decidir sobre a inclusão de débito no rol das cobranças inviáveis, quando o prosseguimento das diligências se afigurar antieconômico, até o valor de 100 (cem) UFM.

Art. 49. Os Diretores dos Departamentos Judicial e de Desapropriacões, nas áreas de suas respectivas competências, ficam autorizados a formalizar acordos para parcelamento de débitos em geral, não superiores a 100 (cem) UFM, observado o limite máximo de 8 (oito) prestações, com acréscimo de juros de 12\% (doze por cento) ao ano, podendo esta atribuição ser delegada diretamente ao Procurador-Chefe de Procuradoria ou Subprocuradoria.

Art. 51. 0 Diretor do Departamento Judicial fica autorizado, ainda, a transigir, a desistir e a celebrar acordos, nos processos discriminatórios, reivindicatórios ou de usucapião de terras, a fim de prevenir demanda ou extinguir as pendências, quando proposto pela Procuradoria competente, em parecer devidamente fundamentado.

Art. 50 Os Diretores dos Departamentos Fiscal e Judicial ficam autorizados ainda a praticar os seguintes atos:

I - concessão de novos prazos para pagamentos de débitos inscritos como Dívida Ativa quando:

a) a notificação do lançamento não for entregue na forma e prazos legais ou regulamentares;

b) a notificação de lançamento não houver sido objeto de publicação por edital; ou

c) ficar caracterizada falha no processamento de documentos, que não caiba responsabilidade ao sujeito passivo da respectiva obrigação.

II - decidir sobre a conveniência de solicitar a extinção do processo de execução, com base no artigo 794, inciso III, do Código de Processo Civil;

III - fixação das normas internas necessárias à cobrança amigável ou judicial e dos respectivos critérios e condições.

Art. 52. Ao Diretor do Departamento de Desapropriacões ficam atribuídos poderes para celebrar acordos para pagamentos de indenizacões, em valores não superiores ao fixado por Assistente Técnico da Municipalidade, em juízo, neles incluídos juros, honorários e demais despesas judiciais e desde que não ultrapasse o montante correspondente a 1.700 (mil e setecentas) UFM.

Ainda, no âmbito dos acordos para parcelamento de débitos inscritos em dívida ativa do Município, foram delegadas aos Procuradores-Chefes das Procuradorias Fiscais e Judiciais (submetidos aos respectivos Diretores) e da Subprocuradorias, e, ainda aos chefes da Seção de Acordos e aos Encarregados de setores as competências para celebrar ou renovar acordos, em limites já dados pelo próprio decreto:

Art. 53. São competentes para autorizar a celebração de acordos, ou de renovação de acordo e para pagamento parcelado de débitos inscritos como divida ativa: (Redação dada pelo Decreto ${ }^{\circ}$ 34.050/1994)

I - No âmbito do Departamento Fiscal: (Redação dada pelo Decreto n $\left.{ }^{\circ} 34.050 / 1994\right)$

1. O Diretor do Departamento, até 36 prestações e limite de 1.500 UFM`s;

2. O Procurador-Chefe da Procuradoria de Ajuizamento e Cobrança (FISC. 1), até 20 prestações e limite de 1.000 UFM`s;

3. O Procurador-Chefe de Subprocuradoria de Cobrança Judicial (FISC. 12) e o Diretor da Divisão de Atendimento ao Contribuinte (FISC. 11), até 15 prestações e limite de 500 (quinhentas) UPM`s; 
4. O Chefe da Seção de Acordos, de Negação Judicial e Extrajudicial e Inviabilização Automática (FISC. 123), até 12 (doze) prestações e limite de 100 UFM`s;

5. Os Encarregados dos Setores de Acordo Judicial (FISC. 1231), e Acordo Extrajudicial (FISC. 1232), até 3 (três) prestações e limite de 6 (seis) UFM`s; (Redação dada pelo Decreto $\left.n^{\circ} 34.050 / 1994\right)$

II - No âmbito do Departamento Judicial: (Redação dada pelo Decreto no 34.050/1994)

1. O Diretor do Departamento, até 36 prestações e limite de 1.500 UFM`s;

2. O Procurador Chefe da Quarta Procuradoria (JUD. 4), até 20 prestações e limite de 1.000 UFM`s;

3. Os Procuradores Chefes das Subprocuradorias JUD. 41 e JUD. 42, até 15 prestações e limite de 500 UFM's;

4. Os Procuradores lotados nas Subprocuradorias JUD. 41 e JUD. 42, até 12 prestações e limite de 100 UFM`s;

5. O Encarregado do Setor de Expediente JUD.4, até 3 (três) prestações e limite de 6 (seis) UFM`s. (Redação dada pelo Decreto n 34.050/1994)

Nota-se, portanto, que os Diretores dos Departamentos Fiscal, de Desapropriação e Fiscal podem transigir e firmar acordos em geral, mas o limite de valor é limitado a 100 Unidades Fiscais do Município. Ademais, os Diretores dos Departamentos Judicial e de Desapropriações somente podem celebrar acordos de parcelamento de dívidas. Também não foi localizada maior especificação das balizados dos acordos que podem ser feitos.

Já no âmbito do Departamento Fiscal, em acordos que envolvem parcelamento de dívida ativa, tanto a competência está bastante capilarizada quanto os limites dos acordos estão bem definidos, assim como o seu limite de valor é bem maior, chegando até a 1.500 UFMs, apesar de esse não ser um valor tão alto.

6.3. Relato: Práticas consensuais identificadas no âmbito da ProcuradoriaGeral do Município de São Paulo

\subsubsection{As experiências analisadas são autênticos "meios consensuais" institucionalizados na Procuradoria-Geral do Município de São Paulo?}

Durante a realização da pesquisa de coleta das experiências consensuais, conforme narradas pelos Procuradores, surgiu a indagação sobre se as práticas apontadas configurariam mesmo "meios consensuais" para "solução de conflitos", conforme os conceitos aqui definidos.

A indagação se deu por alguns motivos:

1) Algumas das práticas adotadas, como o pedido de indenização administrativa, o reconhecimento de benefícios acidentários e o gerenciamento das demandas por 
medicamentos, são atos de reconhecimento de direitos legítimos. São, afinal, efetivados mediante uma decisão da autoridade administrativa, de forma que não haveria uma "negociação", mas sim uma tentativa de convencimento por parte do requerente mediante um procedimento próprio, mais próximo à adjudicação;

2) Nesses mesmos casos, indaga-se se há efetivamente um conflito instalado, pois a administração ainda não teria se contraposto oficialmente ao direito do requerente.

3) Em outras práticas, como o parcelamento de débitos (PPIs) ou o pagamento de precatórios, há pouca ou quase nenhuma margem para o particular negociar de que forma dará o seu acordo, pois já está praticamente tudo definido em regulamento, bastando a sua "adesão".

Guardadas essas considerações, passamos a descrever com mais detalhes cada prática identificada em, ao final do relato da pesquisa, tentar responder aos questionamentos juntamente com a pergunta principal: há uso de meios consensuais pela Administração Pública? Em que grau?

\subsubsection{Termos de Ajuste de Conduta}

No Município de São Paulo, os termos de compromisso firmados com o Ministério Público foram procedimentalizados por meio da criação da "Coordenadoria de Mandados e Acompanhamento de Inquéritos Civis" pelo Decreto n. 52.163/2011. O acompanhamento de Inquéritos Civis instaurados contra a Municipalidade e suas autarquias passou a ser centralizado nesse órgão. Segundo o art. $2^{\circ}$ do Decreto 52.163/2011, o órgão tem atribuições para:

II - manter controle dos inquéritos civis instaurados pelo Ministério Público do Estado de São Paulo, Ministério Público Federal e pelo Ministério Público do Trabalho, providência que se dará sem prejuízo da atuação das Secretarias Municipais, das Subprefeituras, do Instituto de Previdência Municipal de São Paulo-IPREM, da Autarquia Hospitalar Municipal e da Autarquia Municipal de Serviços Auxiliares de Saúde, os quais deverão noticiar a instauração de inquéritos civis ou de procedimentos assemelhados, inclusive quando originários das Defensorias Públicas, encaminhando cópia das respectivas portarias ou atos de instauração à Coordenadoria;

III - coordenar as providências, os prazos e as respostas aos ofícios e solicitações do Ministério Público encaminhados à Procuradoria Geral do Município. 
Segundo o Decreto, os órgãos da Administração Municipal devem, ainda, encaminhar à Coordenadoria, em quinze dias, cópia das respostas que enviarem ao Ministério Público em inquéritos civis.

Na sequência, o Decreto n. 52.164/2011 estabeleceu procedimento para realização dos TACs pela Administração, segundo o qual os órgãos "que receberem do Ministério Público proposta de celebração de Termo de Compromisso de Ajustamento de Conduta (TCAC) em matéria de sua competência, após manifestação acerca da viabilidade técnica de cumprimento de seu objeto, deverão colher o pronunciamento da Procuradoria Geral do Município acerca de sua viabilidade jurídica" (art. $2^{\circ}$ ).

Ficaram estabelecidas duas providências, portanto: (i) a manifestação do órgão quanto à viabilidade técnica do Termo de Compromisso e (ii) a manifestação de viabilidade jurídica pela PGM-SP. É vedada a celebração de TAC fora desses termos (art. $1^{\circ}$ ). Após tais providências, caberá ao titular de cada órgão decidir sobre a celebração do TAC $\left(\operatorname{art.} 3^{\circ}\right)$.

Segunda as entrevistas realizadas, a Coordenadoria participa, em casos extraordinários, de negociações no âmbito das apurações, e já foram assinados alguns TACs com sua participação. Contudo, o procurador que assume a negociação, mesmo nesses casos, não pode, evidentemente, comparecer a uma audiência e decidir por si celebrar ou não um acordo. Então, antes de o procurador ir a uma audiência com o Ministério Público, essas unidades já foram previamente consultadas para que o procurador vá munido de embasamento legal para negociar ou mesmo assinar o TAC.

Ainda segundo a fala de um dos entrevistados, a criação da Coordenadoria tem raiz no "desejo do Município cada vez mais evitar o ajuizamento de demandas judiciais. Mesmo em questões ambientais, em ações de reparação de dano ambiental, a própria Secretaria do Verde e do Meio Ambiente apresenta uma proposta de TAC, o que é uma tendência crescente de o próprio ente querer evitar o ajuizamento de uma demanda".

Ao discorrer sobre a Coordenadoria e os Termos de Compromisso, a existência de um canal de diálogo próprio com o Ministério Público foi destacada como um elemento que favorece a solução consensual de conflitos de forma mais racional, pois torna possível mostrar ao membro do Ministério Público de forma mais clara as dificuldades encontradas na prática e "que uma ação judicial não vai fazer milagre nem fazer que o objetivo seja alcançado", de forma que "já foram evitadas várias ações judiciais, com reuniões".

Um ponto destacado por dois entrevistados em relação ao maior nível de interação entre as partes na celebração do TAC é que "o diálogo se dá entre instituições" e que "na 
outra ponta está sempre o mesmo interlocutor, que é o Ministério Público, o que facilita um pouco na condução".

\subsection{3. "Conciliação" de precatórios}

Com base na possibilidade aberta pela Emenda Constitucional n. 62/2009, no art. 92, $\S 8^{\circ}$, do ADCT, de reservar metade dos recursos destinados ao regime especial de precatórios poderiam ser utilizados para pagamento em acordo direto com o credor. A adoção do regime especial foi feita por meio do Decreto n. 51.105/2009.

Em seguida, o Decreto n. 51.719/2010 criou no âmbito da PGM-SP a Coordenadoria de Precatórios, subordinada diretamente ao Procurador Geral, com as seguintes atribuições $\left(\right.$ art. $\left.2^{\circ}\right)$ :

\footnotetext{
I - acompanhar todas as questões relacionadas ao cumprimento das disposições contidas na Emenda Constitucional $n^{\circ} 62$, de 2009;

II - manter permanente contato com os setores competentes do Tribunal de Justiça do Estado de São Paulo, visando facilitar as ações de competência do Município;

III - cadastrar as requisições judiciais de pagamento, organizar as ordens cronológicas e uniformizar procedimentos;

IV - atuar em juízo em todas as questões relativas aos precatórios expedidos contra o Município de São Paulo;

$\mathrm{V}$ - elevar à homologação judicial as propostas de acordo que vierem a ser aprovadas pela Procuradoria Geral do Município.
}

Foi então criada "Câmara de Conciliação de Precatórios", responsável pela celebração dos acordos, pelo Decreto n. 52.011/2010. Por sua vez, o Decreto n. 52.012/2010 autorizou a realização de acordos envolvendo precatórios que aguardavam na lista, com base na autorização do art. 92 do ADCT, estabelecendo, ainda, os seus critérios e parâmetros, que estabelecia condições diversas de deságio para titulares de precatórios alimentares que fossem portadores de doenças graves (deságio de 5\% contra deságio de $50 \%$ para outros precatórios).

Contudo, foi revogado pelo Decreto n. 52.312/2011, atualmente vigente, que estipula que são autorizados "a celebrar acordos diretos com credores de precatórios da Administração Direta, do Instituto de Previdência Municipal de São Paulo e do Serviço Funerário do Município de São Paulo, mediante aplicação do deságio de 50\% (cinquenta por cento) sobre o valor devido atualizado do crédito".

É interessante notar três pontos sobre o Decreto da Prefeitura. 
Primeiro, nos "considerandos", o decreto é expedido com base na "competência legal conferida à Procuradoria Geral do Município pela Lei n ${ }^{\circ} 10.182$, de 30 de outubro de 1986, para transigir, firmar compromissos e reconhecer pedidos nas ações de interesse da Fazenda Municipal”, o que, segundo os entrevistados, supriu a falta de Lei Municipal específica para regulamentar os acordos envolvendo precatórios.

Segundo, nos "considerandos" também é explicitado que o Decreto foi expedido conforme proposta da própria PGM-SP.

Em terceiro lugar, a opção do Decreto é a aplicação de um deságio fixo de 50\%, que é o máximo permitido pela Resolução n. 123/2010 do CNJ, no art. 20, §2², alínea $b$.

Para garantir a isonomia e o acesso igualitário de todos ao acordo, o Decreto n. 52.312/2011 estabeleceu que a convocação de todos os credores deveria ser feita mediante edital, e com ampla divulgação. Os acordos contariam com recursos limitados a $50 \%$ dos valores destinados ao regime especial de precatórios. O edital ainda deveria conter os critérios de desempate, caso os valores habilitados fossem maiores que o valor disponível. Assim, os credores seriam ordenados da seguinte forma: "I - portadores de doença grave nos precatórios alimentares e, nesses, por ordem cronológica do precatório; II - maiores de 60 (sessenta) anos nos precatórios alimentares e, nesses, por ordem cronológica do precatório; III - ordem cronológica do precatório ou ordem crescente de valor" $\left(\operatorname{art.~} 3^{\circ}\right)$.

Até hoje, foram expedidos dois editais pela Câmara de Conciliação de Precatórios: o Edital 01/2012 e o 01/2014. Ambos os editais preveem os descartes das propostas que não puderem ser contempladas por ultrapassarem o valor destinado aos acordos.

Um dos pontos destacados nas entrevistas foi que, para viabilizar a instituição da Câmara, utilizaram a competência genérica para a celebração de acordos pela própria PGM-SP, contando apenas com regulamentação por Decreto do Prefeito e abrindo mão do processo legislativo, o que denota que tal competência pode ser utilizada de forma mais ampla.

No entanto, foi chamada a atenção para o fato de os acordos terem se tornado viáveis porque houve decreto estabelecendo quais eram os parâmetros, o que deu um respaldo grande para garantias de isonomia. Segundo um dos entrevistados, trabalhar com o deságio fixo em detrimento da negociação caso a caso, e com expedição de edital já contemplando a ordem de pagamentos de acordo com a qualidade do credor, foi a melhor opção para garantir a isonomia. "Seria difícil conseguir viabilizar a negociação de acordo com a condição individual de cada credor". 
Outro ponto é a discussão sobre o caráter "consensual" da medida. Segundo os entrevistados, não pode se tratar de autêntica conciliação, porque as opções são aderir ou não, não havendo flexibilidade para definir o valor. De fato, também não há qualquer intermediação de terceiro que justifique tomar o termo "conciliação" em seu sentido técnico.

Essa prática, contudo, está sujeita às decisões do STF que declararam inconstitucional o art. 92 do ADCT e que aguardam modulação de seus efeitos em relação às regulações já existentes na data de sua prolação, conforme já exposto no item 4.4.

\subsubsection{Pedido administrativo de indenizações por responsabilidade civil} extracontratual

O Decreto n. 53.066/2012 instituiu no âmbito da Procuradoria um procedimento extrajudicial de indenizações por responsabilidade civil por omissões ou ações decorrentes de prestação de serviço público.

O Decreto traz, em seus "considerandos", a menção à "solução extrajudicial de litígios [que] constitui valioso instrumento para evitar o excessivo ônus financeiro imposto à Fazenda Pública Municipal em decorrência de sua condenação judicial”.

A indenização extrajudicial também foi procedimentalizada pelo Decreto. O procedimento, no caso, inicia-se com um requerido dirigido à PGM-SP. O pedido é então, encaminhado à Coordenadoria de Mandados e Acompanhamento de Inquéritos Civis, que o enviará ao Departamento da Procuradoria Geral do Município competente para a sua instrução e análise.

Nos termos do Decreto, a autoridade que receber o pedido deverá adotar todas as medidas adequadas à instrução do processo, podendo-se requisitar, diretamente a quaisquer autoridades da Administração Municipal, todas as informações, documentos, perícias ou providências necessárias à elucidação dos fatos, a fim de apurar se houve a omissão ou ação adequada.

$\mathrm{Na}$ prática, as entrevistas revelaram que em muitos casos o requerente é chamado para trazer mais elementos, podendo até mesmo ser ouvidas testemunhas, ainda que segundo a lei processual fossem suspeitas ou impedidas. Essas diligências são evitadas caso já se tenha um bom grau de certeza do direito da pessoa ou quando o Município verifica sua ausência de responsabilidade. 
Existe também uma preocupação com o contraditório, pois o Decreto prevê que "quando os elementos colhidos puderem conduzir ao indeferimento do pleito, o interessado será intimado para manifestação final no prazo de 10 (dez) dias".

Previu-se no decreto que a decisão será título executivo extrajudicial, nos termos do art. 585, inciso II, do $\mathrm{CPC}^{585}$.

O objetivo, segundo um dos entrevistados, foi diminuir o contencioso judicial, pois há situações em que "fica evidente que existe uma responsabilidade por parte da administração".

Os casos mais recebidos dizem respeito a acidentes de trânsito, danos causados por enchente, por queda de árvores e por buracos nas vias públicas.

Nota-se que o Decreto não traz um critério para a concessão das indenizações, esse é extraído do próprio sistema de responsabilidade civil. Na prática, segundo um dos entrevistados,

\begin{abstract}
"nosso critério balizador é, basicamente, a chance de sucesso que teríamos com uma ação judicial. Então é preciso, claro, que a pessoa demonstre que ela é a credora daquele valor, a ocorrência do dano, o nexo, tudo aquilo que envolve fechar o âmbito da responsabilidade civil. Fechados todos os elementos da responsabilidade civil, nós vamos verificar se de fato havia alguma causa excludente da responsabilidade da administração. Se não encontramos nenhuma causa excludente, se o valor pedido de indenização é compatível em relação aos danos, nós concedemos a indenização administrativa, se a necessidade de acesso ao Judiciário".
\end{abstract}

Os procedimentos para verificação da responsabilidade são internos, as subprefeituras ou secretarias normalmente são envolvidas na apuração dos fatos, simples ou não, como "houve chuva na região?" ou "há quanto tempo existe o buraco?”. Isso, por outro lado, acaba atrasando um pouco o procedimento.

Outro ponto é que prevê que, se houver ação judicial no curso do pedido administrativo, este é dado como prejudicado (art. $3^{\circ}$, parágrafo único, do Decreto $n$. 15.563/2012).

Um dos entrevistados mencionou a necessidade de objetividade no procedimento, sobretudo se o direito do requerente for evidente. Não haveria por que instruir o procedimento desnecessariamente.

585 Art. 585. São títulos executivos extrajudiciais: (...) II - a escritura pública ou outro documento público assinado pelo devedor; o documento particular assinado pelo devedor e por duas testemunhas; o instrumento de transação referendado pelo Ministério Público, pela Defensoria Pública ou pelos advogados dos transatores. 
A decisão, ao final, é tomada de acordo com o valor do requerimento: até $\mathrm{R} \$ 10$ mil, ao Diretor do Departamento; até R \$ 50 mil, ao Procurador-Geral; acima de R \$ 50 mil, ao Secretário Municipal de Negócios Jurídicos.

Um ponto interessante é que, no desenho do procedimento, buscou-se evitar que os procuradores que atuam diretamente na via judicial participassem da análise dos pedidos administrativos, com a finalidade de evitar a postura de resistência. Segundo um dos entrevistados, "é muito difícil você lidar ao mesmo tempo. O mesmo procurador que defende judicialmente, onde você já está em uma postura de resistência, fazê-lo trabalhar no âmbito do contencioso administrativo com a questão da testemunha, por exemplo, é muito difícil".

Sobre o cumprimento das indenizações, a entrevista com um de seus responsáveis revelou como se dá:

\begin{abstract}
“(...) Sem precatório, os pagamentos são feitos mediante o depósito em uma conta indicada pelo credor. Temos uma dotação orçamentária para isso, eu tenho que observar essa dotação; caso ela esteja esgotada na hora de pegar o valor, a gente fala: "segura um pouquinho, espera virar o ano porque eu não posso te pagar agora, mas você entra na frente dos próximos pedidos". Quase como que de lado você tivesse uma "filinha". Mas eu tenho uma dotação para fazer esse pagamento, feito diretamente, sem a necessidade de expedição de um ofício, como no regime de precatório. É uma dotação específica para responsabilidade, salvo engano."
\end{abstract}

\title{
6.3.5. Benefícios acidentários
}

Também foi instituída no âmbito da PGM-SP uma medida de prevenção de demandas em benefícios acidentários bastante simples. A Secretaria que recebe o pedido de seu servidor acidentado verifica a parte fática, se houve o dano a saúde e nexo de causalidade. Na sequência, é verificado pela Procuradoria se é possível enquadrar o acidente como "acidente de trabalho". Não há, segundo o entrevistado do departamento ao qual é atribuída essa análise, uma postura de resistência: havendo acidente do trabalho, o benefício é concedido.

Aqui se destaca o papel da jurisprudência: segundo o procurador, o fato de a jurisprudência ser bastante clara e fechada na configuração de acidente do trabalho levou a Procuradoria a adotar uma postura de análise em vez de resistência.

Segundo a entrevista, essa medida de análise mantém o contencioso acidentário muito baixo: "tem alguma coisa na ordem de sessenta ou setenta demandas, que para um contexto de duzentos mil servidores é muito baixo". 


\subsubsection{Gerenciamento das demandas por medicamentos}

É conhecido o volume de demandas ajuizadas contra a Administração Pública com pedido de concessão de medicamentos ou procedimentos em saúde. Há, ainda, pesquisas demonstrando que a judicialização dos pedidos de medicamentos causam algumas distorções, como: (i) iniquidades na distribuição dos medicamentos, pois apenas uma parcela da população consegue ter acesso ao Judiciário e obter os mandados; (ii) desatenção do Judiciário em relação a aspectos importantes da política pública que o Executivo já traçou, colaborando pouco para a melhoria da saúde da população em geral e causando problemas de gestão ${ }^{586}$.

Segundo o constatado, há também desencontros em relação à necessidade de ajuizamento da ação, pois muitas vezes o medicamento está disponível, sendo o problema logístico ou de gerenciamento, ou mesmo de pedido sem que tenha havido negativa prévia.

O Município tem buscado meios de melhor gerenciar essas demandas por medicamentos, havendo, no momento uma frente concreta.

No $8^{\circ}$ andar do Fórum Hely Lopes Meirelles, ao lado dos Cartórios dos Juizados Especiais da Fazenda Pública, foi instalada uma sala para o "Projeto Triagem Farmacêutica". Essa unidade é fruto de um Convênio firmado entre o Tribunal de Justiça de São Paulo e a Secretaria de Saúde do Estado de São Paulo (Convênio n. 002/2013, disponibilizado no DJe em 23 de janeiro de 2013 ${ }^{587}$ ), com vigência entre 13/11/2013 e 12/11/2017, não contando, a princípio, com a participação do Município.

O procedimento é assim relatado pelo próprio Tribunal:

“Ao se apresentar no cartório dizendo que precisa de determinada atenção na área da saúde, o paciente é encaminhado para o setor de triagem que fica próximo ao cartório. Neste setor, o paciente apresenta toda a documentação pertinente ao problema e recebe orientação além de ser cadastrado no SUS. É realizada uma triagem farmacêutica para possível reintegração do paciente aos Serviços e Programas Oficiais de Assistência Farmacêutica do SUS, com escopo de evitar a propositura de medidas judiciais desnecessárias. O paciente recebe a informação de como poderá obter o que é necessário para seu tratamento. Ele é informado sobre a apreciação administrativa pela Secretaria do Estado da Saúde, da solicitação de medicamentos, insumos médicos

\footnotetext{
${ }^{586}$ Cf. WANG, Daniel Wei Liang. Poder Judiciário e participação democrática nas políticas públicas de saúde. Dissertação (mestrado). São Paulo, Faculdade de Direito da Universidade de São Paulo, 2009, p. 41. 587 Disponível em: $<$ https://www.dje.tjsp.jus.br/cdje/consultaSimples.do?cdVolume=7\&nuDiario=1341\&cdCaderno=10\&nuSeq pagina $=68>$. Acesso em: 13.12.2014.
} 
hospitalares e dietas. E em caso de propositura da ação, o Magistrado recebe do setor de triagem informações técnicas para subsidiar a análise das solicitações do paciente" ${ }^{, 588}$.

Segundo um dos entrevistados, é desejo do Município integrar esse gerenciamento, pois o diálogo com a Secretaria de Saúde do Estado é importante na medida em que há medicamentos e procedimentos que podem ser fornecidos por um dos entes, mas não pelo outro. Possibilitaria, portanto, uma atuação conjunta que, na prática, já é feita informalmente.

Em sua fala, ele ainda aponta algumas peculiaridades do pedido, que devem ser levadas em conta no gerenciamento das ações de medicamentos:

“Às vezes a pessoa pede o medicamento, pede [o remédio pela] marca. Espera aí; se no nosso registro a gente não dá a marca porque tem um genérico, você vai ter que justificar. Por que você não pode ter um genérico, que é igual?. Às vezes a pessoa não tem receita. Então tem algumas questões formais que a pessoa tem que atender".

O gerenciamento, segundo a entrevista, pode inclusive prevenir demandas insensatas por parte dos requerentes, que muitas vezes acabam sendo propostas sem antes passar pela via administrativa, o que acaba retardando o recebimento do medicamento. Um dos exemplos dados foi a obtenção de fraldas, que tem uma cota por pessoa em cada ente público. Quando o requerente precisa de mais fraldas, acaba indo diretamente ao Judiciário para pleitear todas as unidades, não apenas as excedentes à cota, sendo que poderia ter obtido já na via administrativa ao menos o número mínimo.

Segundo o mesmo entrevistado,

"[há] uma tentativa do tribunal e nós estamos colaborando para tentar reduzir essas ações judiciais, que para nós é um transtorno burocrático, porque ela é uma ação como outra qualquer, você precisa controlar prazo junto com aquela ação de uma indenização milionária de uma multa contratual. Então a gente tem que tomar algumas cautelas para reduzir um pouco. É pouco, mas já ajuda bastante".

Até a conclusão da pesquisa, estava também sendo organizado um evento de conciliação, abrangendo Município, Estado e Governo Federal, para extinguir ações com o fornecimento direito do medicamento pleiteado. Da parte do Município, foi feito levantamento dos casos comuns que já poderiam ser extintos, para posterior convocação dos autores.

588 Disponível em: < http://www.premioinnovare.com.br/praticas/triagem-farmaceutica-no-juizado-especialda-fazenda-publica-de-sao-paulo/>. Acesso em: 13.12.2014. 


\subsubsection{Conciliação judicial?}

Em visita ao Juizado Especial da Fazenda Pública, constatou-se a partir das entrevistas realizadas que as audiências de conciliação simplesmente não ocorrem, a despeito da previsão legal do art. $8^{\circ}$ da Lei n. 12.153 , que visa fomentar a conciliação em audiência no âmbito de tal procedimento.

A razão seria a falta de autorização específica para o procurador realizar acordos em audiência. De fato, não foi adotada lei nem estadual nem municipal para prever as hipóteses de acordo, conforme previsto no próprio art. $8^{\circ}$.

Uma das entrevistadas no Juizado afirmou que, assim que o órgão iniciou seu funcionamento (instalado em junho de 2010), as audiências eram designadas, mas nunca foi realizado um acordo, tendo em vista a falta de autorização dos procuradores. Ademais, quando instalado o Juizado, os próprios servidores, todos vindos da Vara de Acidentes do Trabalho, é que conduziam as audiências, sem terem recebido nenhum treinamento específico para isso.

Nas entrevistas realizadas na PGM, confirmou-se que a prática da conciliação judicial é muito rara, sendo feita apenas pontualmente em casos bem específicos: "Normalmente, em uma situação como essa, a gente verifica que houve um erro, [que] existe uma chance muito grande de a administração perder, [e] tentamos fazer um acordo para evitar uma sucumbência maior" ${ }^{, 589}$. As audiências são raramente realizadas, e poucos juízes a convocam. Contudo, não existe a prática sistematizada.

Por outro lado, um dos entrevistados reconhece que pode ser útil a audiência para verificar a plausibilidade do direito da parte contrária: “Às vezes acontece do procurador não perceber, fez a contestação "batida” e chegar lá e ver uma situação dessas. Mas aí toma ciência e pede uma suspensão, para suspender o processo para analisar alguma coisa".

\footnotetext{
${ }^{589}$ Segue relatando o entrevistado: "Então é uma situação como essa: a gente verifica que houve um erro, existe uma chance muito grande de a administração perder, tentamos fazer um acordo para evitar uma sucumbência maior. Eu tive um caso particular, que eu lidei nesse assunto, que era de uma multa que foi aplicada errada; estávamos discutindo, tínhamos uma tese de defesa, mas uma tese que não devia ser vencedora e a parte resolveu: 'eu quero resolver meu problema'. Então vamos fazer o seguinte: na proposta que eles fizeram, eu calculo o valor da multa como se ela fosse correta, o problema todo era a base de cálculo. Eu falei 'tá bom, calcula'. Nós estávamos na fase de embargos. "E a sucumbência?". "Não, nós abrimos mão da sucumbência". Isso é claro, eu tenho que pegar e submeter essa proposta, justifico e submeto a proposta. Aí normalmente, quando envolve um valor muito grande a Procuradoria-Geral é envolvida. Eles concordam e a gente faz um acordo, normalmente uma petição conjunta. Então eu já tive um ou dois casos nesse sentido".
} 
Uma lei que disciplinaria os acordos no Juizado Especial é uma demanda interna da Procuradoria, pois consideram que resolveria várias demandas. No momento, sem a lei, são relatados óbices para a realização da conciliação: (i) a falta de autonomia do procurador que atua diretamente no processo e (ii) a existência de cultura de resistência, tanto do administrador quanto do próprio procurador que lida no contencioso.

São reconhecidas, contudo, algumas possibilidades que o Juizado propicia para redução da litigiosidade e da resistência no âmbito da PGM-SP. O fato de não haver sucumbência no primeiro grau, mas apenas no segundo grau, caso o Município venha a recorrer, tem sido utilizado como parâmetro para a redução de recursos, que são dispensados quando a decisão desfavorável à Administração está dentro de parâmetros tidos como razoáveis e equiparados ao que poderia ser reconhecido administrativamente. Segundo um dos entrevistados, "um passo menor antes de a gente dar um maior que seria realmente criar um contexto de conciliação e criar uma cultura de não resistir".

Além disso, a juíza da $1^{\text {a }}$ Vara do Juizado Especial da Fazenda Pública afirmou que está tentando por em prática uma forma de incentivar a Administração a decidir mais e melhor: em muitos casos, as decisões de antecipação de tutela por ela deferidas são no sentido de apontar a ilegalidade ou a falta de fundamentação no ato administrativo, anulálo, e devolvê-lo para que a Administração o revise, o que, segundo ela, muitas vezes ocorre. Isso, segundo ela, tem criado uma postura de maior motivação dos atos administrativos, "porque se [a decisão de antecipação de tutela] está motivada e fundamentada adequadamente, dificilmente haverá revisão por parte do Judiciário".

Na Justiça do Trabalho, a PGM-SP tem uma postura institucional de não realizar nenhum tipo de acordo, por uma questão de direito: na Administração direta, apenas os trabalhadores terceirizados são submetidos à CLT (segurança, limpeza, etc.), sendo os demais servidores públicos estatutários. E, no caso, o Município defende a tese de que não tem responsabilidade pelos trabalhadores terceirizados. A PGM-SP tem buscado, inclusive, a dispensa do comparecimento das audiências.

\subsection{8. Área fiscal e Dívida Ativa}

A área fiscal é responsável pela inscrição e cobrança da dívida ativa tributária do Município. É a área que, ao longo das entrevistas, foi mais apontada como sendo de pouca 
flexibilidade de acordos, porque necessitaria de lei para prever a forma como eles poderiam ser feitos.

Um dos entrevistados relatou uma vez ter participado de um mutirão de conciliação enquanto atuante na dívida ativa fiscal, e afirmou não ter conseguido realizar nenhum acordo, porque não tinha embasamento legal para tanto, apenas o programa de parcelamento então vigente.

Não obstante, o Município apresenta alguns programas que permitem realizar acordos envolvendo dívida ativa fiscal e não fiscal, bem como débitos ainda não inscritos. Todos são disciplinados em instrumento próprio com parâmetros bem definidos.

\subsubsection{Parcelamento de débitos}

Em relação a débitos de particulares já inscritos na dívida ativa, há programas permanentes de parcelamento. Atualmente, os dois instrumentos que disciplinam tais parcelamentos: a Portaria PGM n. 16/2014 e a Portaria 4/2014 da Procuradoria Fiscal.

Contudo, aqui há apenas parcelamento, ou seja, o Município apenas abre mão da cobrança judicial (enquanto o acordo esteja sendo cumprido) e do direito de receber o débito de uma vez, mantendo, contudo, seu valor integral e seus acréscimos.

A Portaria n. 16/2014 da PGM, expedida pelo próprio Procurador-Geral, baseia-se na sua competência prevista no art. $7^{\circ}$ do Decreto n. 27.321/88, especialmente a competência para "confessar, desistir, transigir, firmar compromissos e reconhecer pedidos nas ações de interesse da Fazenda Municipal, podendo delegar estas atribuições”.

A Portaria delega a competência de realizar o acordo para os Diretores de Departamento, inclusive elevando o teto acima do valor previsto no Decreto n. 27.321/88:

Art. $6^{\circ}$ Os Diretores do Departamento são competentes para autorizar parcelamento para pagamento de débitos inscritos em dívida ativa por número de contribuinte até o valor de $\mathrm{R} \$ 3.000 .000,00$, podendo essa competência ser delegada, por faixa de valor, por meio de norma complementar a ser expedida pelo Departamento respectivo.

Parágrafo único: $\mathrm{O}$ valor de referência constante deste artigo será atualizado anualmente, de acordo com a variação do Índice de Preços ao Consumidor Amplo IPCA, apurado pelo Instituto Brasileiro de Estatística - IBGE.

Por fim, também disciplina as condições em que poderá ser feito o parcelamento: 
Art. $7^{\circ}$ No âmbito dos Departamentos, poderá ser autorizado parcelamento em até 60 parcelas mensais e sucessivas para pagamento dos débitos.

$\S 1^{\circ}$. Com a primeira parcela deverão ser quitadas as custas judiciais e as despesas processuais.

$\$ 2^{\circ}$. Poderá ser autorizado até 03 reparcelamentos desde que a primeira parcela seja percentualmente superior às demais.

Art. $8^{\circ}$ A efetivação do parcelamento, por qualquer forma, implica confissão irretratável do débito e configura confissão extrajudicial e renúncia a qualquer defesa ou recurso administrativo ou judicial, acarretando, ainda, a interrupção da prescrição na forma artigo 174, parágrafo único, inciso IV do Código Tributário Nacional.

A Portaria 4/2014 do Departamento Fiscal da Procuradoria fixa, por sua vez, os critérios e condições para a celebração de parcelamento de débitos inscritos na Dívida Ativa por ele administrados.

A Portaria também é expedida com base na competência prevista no art. 50, inciso III, do Decreto n. 27.321 , qual seja a de "fixação das normas internas necessárias à cobrança amigável ou judicial e dos respectivos critérios e condições". Para autorizar os parcelamentos, a Portaria ainda atribuiu aos Procuradores lotados na $1^{\text {a }}$ Procuradoria acordos no valor total de até $\mathrm{R} \$ 1.000 .000,00$ (um milhão de reais) (art. $4^{\circ}$, inciso III).

Ademais, estabeleceu os seguintes parâmetros para acordo:

Art.5․ Para definição do número máximo de parcelas, serão considerados os seguintes parâmetros:

I - para débitos a parcelar iguais ou superiores a R \$ 200,00 (duzentos reais) e inferiores a R \$ 111.000,00 (cento e onze mil reais), em até 36 (trinta e seis) parcelas, observandose o valor mínimo de $\mathrm{R} \$ 100,00$ (cem reais) por parcela.

II - para débitos a parcelar iguais ou superiores a R\$ 111.000,00 (cento e onze mil reais), em até 60 (sessenta) parcelas, observando-se o valor mínimo de $\mathrm{R} \$ 3.000,00$ (três mil reais) por parcela.

(...)

Art. $7^{\circ}$. Os débitos deverão ser parcelados nas seguintes condições:

I - com a primeira parcela será paga a primeira fração dos honorários e o total das custas e despesas processuais;

II - as demais parcelas ficarão sujeitas a atualização monetária pelo IPCA/IBGE e juros de $1 \%$ (um por cento) ao mês, nos termos das Leis no 13.275/02 e 13.475/02;

III - os honorários também ficarão sujeitos à correção e juros na forma do item II deste artigo e serão pagos juntamente com as respectivas parcelas, sendo fracionados da seguinte forma:

a) tantas vezes quantas forem as parcelas do parcelamento, se a dívida se encontrar em cobrança amigável (extrajudicial), nos termos do Decreto n ${ }^{\circ} 47.871 / 06$;

b) até 10 (dez) vezes, se a dívida se encontrar em cobrança judicial.

IV - as parcelas vencerão no último dia útil de cada mês.

\subsubsection{Programas de Parcelamento Incentivado (PPIs)}


Os Programas de Parcelamento Incentivado abrangem débitos em favor do Município de natureza tributária ou não, sendo instituídos por lei e normalmente contemplam uma contrapartida vantajosa ao devedor.

O primeiro programa foi instituído pela Lei Municipal n. 14.129/2006 e previa a inclusão de débitos tributários “constituídos ou não, inclusive os inscritos em Dívida Ativa, ajuizados ou a ajuizar, em razão de fatos geradores ocorridos até 31 de dezembro de 2004.”, com abatimento de percentual da multa e dos juros incidentes sobre o tributo:

\footnotetext{
Art. $4^{\circ}$ Sobre os débitos tributários incluídos no PPI incidirão atualização monetária e juros de mora, até a data da formalização do pedido de ingresso, além de custas, despesas processuais e honorários advocatícios devidos em razão do procedimento de cobrança da Dívida Ativa, nos termos da legislação aplicável.

$\S 1^{\circ}$ Em caso de parcela única, o débito tributário consolidado na forma do "caput" será desmembrado nos seguintes montantes:

I - montante principal, constituído pelo tributo, atualização monetária, custas, despesas processuais e $\mathbf{2 5 \%}$ (vinte e cinco por cento) da multa;

II - (VETADO)

$\S 2^{\circ} \mathbf{E m}$ caso de pagamento parcelado, o débito tributário consolidado na forma do "caput" será desmembrado nos seguintes montantes:

I - montante principal, constituído pelo tributo, atualização monetária, custas, despesas processuais e $\mathbf{5 0 \%}$ (cinqüenta por cento) da multa;

II - (VETADO)

$\S 3^{\circ} \mathrm{O}$ montante residual ficará automaticamente quitado, com a conseqüente anistia da dívida por ele representada, para todos os fins e efeitos de direito, em benefício do devedor, no caso de quitação do montante principal.
}

A Lei ainda estabeleceu como prazo para ingresso no PPI, "o último dia útil do segundo mês subseqüente à publicação do regulamento desta lei” (art. $\left.4^{\circ}, \S 2^{\circ}\right)$, podendo o Poder Executivo prorrogá-lo por mais 60 dias por Decreto (art. $4^{\circ}, \S 6^{\circ}$ ).

A lei disciplinou também a forma do parcelamento (de parcela à vista até 120 prestações) e os acréscimos mensais que incidiriam. Permitiu, ainda, a inclusão de débitos não tributários, mas, nesse caso, sem abatimento de qualquer percentual da multa. Finalmente, também permitiu a compensação das dívidas inscritas no PPI com créditos líquidos, certos e não prescritos, vencidos até o exercício de 2004, que o contribuinte tenha contra o Município de São Paulo, exceto os decorrentes de precatório.

A Lei n. 15.406/2011 instituiu o segundo PPI, abrangendo débitos decorrentes de fatos geradores ocorridos até 31 de dezembro de 2009.

Segundo as entrevistas realizadas, esses programas têm um impacto orçamentário muito grande, aumentando a arrecadação no curto prazo.

Uma das entrevistadas apontou que a instituição do PPI "é uma questão de discricionariedade política". Salientou a importância de, sendo um programa que concede um desconto, haver uma ponderação: 
"Um dado interessante é que existe sempre um fator de ponderação nessa discricionariedade do acordo: se você rotineiramente oferecer essa opção ao contribuinte, você pode gerar um efeito danoso... É um incentivo ao devedor inadimplente. Ele para de pagar porque dentro de cinco anos a Prefeitura baixa uma lei e permite que ele pague sem a multa, ou com abatimento de $50 \%$ da multa. São fatores que o político tem que sopesar para que o programa seja eficiente, mas não desmoralize".

A visão foi confirmada por outro entrevistado:

\begin{abstract}
"Ele gera um ciclo negativo complexo. Porque a partir do momento que se dá vantagens para o pagamento aos devedores de tributos, isso inibe o pagamento voluntário na espera que esse benefício surja em algum momento. A administração optou por isso geralmente quando ela precisou de recursos que estavam acumulados, então ela dá essa possibilidade com algumas condições. Mas realmente é uma questão um tanto quanto complexa, porque parece que torna esse desconto como sendo algo normal e esperado pelo devedor de tributos. Isso realmente é um tanto quanto complicado. Então gera esse efeito contrário que eu disse agora a pouco, desestimula o pagamento voluntário normal no aguardo de que haja um parcelamento".
\end{abstract}

As motivações da instituição do programa são basicamente: (i) a necessidade de o Município em levantar recursos acumulados; (ii) o melhor gerenciamento da dívida vencida; e (iii) a morosidade dos meios judiciais para se atingir tais objetivos.

\title{
6.3.9. Mecanismos de prevenção de litígios: súmulas administrativas e normas de racionalização da litigância
}

Outra competência do Procurador-Geral do Município prevista na Lei 10.182/86 e confirmada no Decreto n. 27.321/1988 é a elaboração de Súmulas de Jurisprudência Administrativa, que precisam ser aprovadas pelo Secretário de Assuntos Jurídicos.

Segundo um dos entrevistados, que já ocupou o cargo de Procurador-Geral, as súmulas serviram, inicialmente, para orientar a atuação judicial e a dispensa de recurso nos casos de resultados judiciais já muito bem definidos e com jurisprudência consolidada.

Posteriormente, passaram a ser emitidas súmulas direcionadas à prevenção de litígios em direito administrativo estrito. Sem caráter vinculante, as súmulas são consideradas orientações de conduta para a Administração: “Ou seja, para nós, determinada posição é essa que prevalece em função do que nós conseguimos extrair do Poder Judiciário. Então, tendo isso em vista, a Administração tem que passar a agir assim". 
O Município de São Paulo ainda adotou medida desjudicializante no tocante às execuções fiscais. A Lei n. 14.800, de 25 de junho de 2008, autoriza a não propositura (art. $1^{\circ}$ ) e a desistência ( $\operatorname{art} .2^{\circ}$ ) de execuções fiscais de valor consolidado igual ou inferior a $\mathrm{R} \$$ 610,00 (seiscentos e dez reais), valor que pode ser atualizado a critério do Poder Executivo pelo IPCA ${ }^{590}$.

\subsection{Relato: percepções dos entrevistados}

O presente tópico relata as percepções emitidas pelos entrevistados sobre o uso de mecanismos consensuais, para tentar distinguir onde estariam os possíveis problemas.

\subsubsection{Sobre meios consensuais em geral}

Uma das perguntas feitas foi sobre o que o entrevistado entendia por "meios consensuais".

As respostas variaram: há uma visão mais ampliativa, que os considerava como "qualquer forma de evitar uma ação judicial, como a criação de um órgão para evitar litígios, a elaboração de um acordo judicial".

Há outra mais restritiva, que os enquadrava "como aquela definição clássica, uma forma de composição de vontades”. A entrevistada que forneceu essa resposta sentiu dificuldade em enquadrar a Administração Pública em um meio consensual:

\footnotetext{
"acho que estou um pouco impregnada da noção tradicional de que a manifestação da vontade da administração é expressa por forma de lei, e a composição só vai acontecer se houver um tipo de autorização legal, mais genérica ou mais específica, de que nós representantes do ente não estamos legitimados a fazer algo que a lei não disciplina. Aquele princípio clássico, da legalidade na acepção da Administração, ou seja, não apenas não fazer o que é proibido, mas só fazer o que é permitido".
}

6.4.2. Sobre as vantagens dos meios consensuais e sede adequada para sua prática

590 MUNICÍPIO DE SÃO PAULO. Lei n. 14.800, de 25 de junho de 2008. Disponível em: <http://ww2.prefeitura.sp.gov.br//arquivos/secretarias/financas/legislacao/lei-14800-2008.pdf>. Acesso em: 09.12.2014. 
Uma das principais vantagens dos meios consensuais apontadas foi a possibilidade de estabelecimento de comunicação institucional e de melhor gerenciamento, "para evitar que venham aquelas decisões em que o Judiciário indica para a Administração quais políticas públicas devem ser feitas".

A aproximação da Administração com a realidade do outro (instituição ou particular) e vice-versa também foi uma vantagem apontada.

Também foi apontada a necessidade de buscar soluções para os conflitos que não envolvam o Poder Judiciário, pois essa realidade [de judicialização dos casos] não estaria funcionando.

A retomada ou manutenção da relação também foi um fator apontado, especialmente em relações contratuais, onde os prejuízos do conflito são de ambas as partes. Um dos entrevistados defendeu a criação de câmaras de conciliação para evitar litígios nessas situações.

Defendeu também as vantagens de se fazer um acordo ou ao menos uma avaliação em fase preliminar de demandas que envolvam obrigação de fazer, prestação de serviços públicos, para que o atendimento possa ser imediatamente feito.

Sobre a sede adequada para se estabelecer uma prática consensual, A PGM foi considerada um local adequado para a tomada de medidas desjudicializantes e de solução consensual, por centralizar todo o contencioso, podendo, assim, atuar em conjunto com os demais órgãos.

As próprias Secretarias também foram apontadas como instâncias adequadas, mas com a ressalva de que deveria haver uma forte regulação e a participação dos procuradores do Município, como já acontece com os termos de compromisso.

As entrevistas em geral mostraram uma boa visão dos meios consensuais, especialmente enquanto alternativa ao Judiciário, mas revelaram também preocupação com vários aspectos, como veremos nos próximos itens.

\subsubsection{Sobre óbices para adoção dos meios consensuais}

\subsubsection{Sobre os princípios da supremacia e indisponibilidade do interesse} público 
Sobre os princípios da supremacia e da indisponibilidade, duas percepções de entrevistados merecem destaque.

Um deles alerta que, de fato, o Poder Público não pode ser tratado como o particular para fins de negociação:

\begin{abstract}
"ela [a Administração Pública] é uma pessoa jurídica, mas uma pessoa jurídica especial, o capital público que poderia usado nessas transações ou mesmo o interesse público que poderia ser eventualmente transacionado, ele guarda algumas características, algumas peculiaridades, que limitam a liberdade que existe na área privada. E um ponto que eu acho muito interessante de colocar, para não confundir isso com intransigência, nem com imposição de poder ou de qualquer outra postura radicalizada, é que eu acho que isso vem do respeito com o contribuinte, com o capital que o poder público lida, no cumprimento de suas tarefas, inclusive, eventualmente, para essa busca de soluções alternativas, é um capital público oriundo dos tributos, então por respeito ao contribuinte que essas soluções não sejam feitas de maneira leviana. Então isso pra mim é um princípio a ser seriamente considerado."
\end{abstract}

Para tal entrevistado, a indisponibilidade do interesse público seria um limitador não para que o Poder Público fizesse acordos, mas sim para que praticasse renúncias que, neste caso, deveria estar parametrizadas:

\footnotetext{
"Uma transação feita na área privada ela geralmente envolve algumas renúncias. O problema do poder público é o que renunciar e como renunciar, e qual seria o estabelecimento de competência para a realização dessas renúncias. Essa é uma dificuldade muito grande. Quando há uma permissão legal, com determinados parâmetros pré-estabelecidos, como, por exemplo, aquele PPI, aquele plano de parcelamento tributário do Município de São Paulo, ele já prevê uma redução, que é uma renuncia, uma redução geralmente em verbas acessórias dos tributos, mas já é uma renúncia."
}

A preocupação demonstrada na entrevista era também com uma atividade não padronizada do procurador individual em termos de acordo, nos casos em que houvesse concessão, "porque nós abriríamos a possibilidade não só de fraude e corrupção, como daquilo que eu também mencionei, da questão do desrespeito ao contribuinte":

\footnotetext{
"essa é a grande dificuldade a se enfrentar na área pública: como que um procurador, um advogado público, poderia nesse momento, seguindo seus critérios pessoais, abrir mão de algo que já está pré-definido, num processo administrativo que se transformou, a rigor, então, em um ato administrativo. Essa é a dificuldade que nós tivemos que enfrentar numa ocasião e que gerou até um parecer negativo nosso quanto a essa possibilidade, de que o procurador pudesse reduzir, de acordo com o seu critério individual, valores dessa natureza."
}

Contudo, o entrevistado pontuou que os acordos que envolvam um procedimento mais bem estruturado, que não impliquem renuncia de direito, mas sim matéria de fato, 
seriam plenamente possíveis. Contudo, pontua que não seria exatamente um acordo, mas sim uma admissão pela Administração do direito da pessoa.

Outro entrevistado critica a visão que normalmente se tem sobre o interesse público: "É entender o interesse público como ele realmente é e não de uma forma confortável, porque é muito confortável eu usar o interesse público imobilizante, vamos dizer assim. 'Eu estou defendendo o interesse público então eu não posso transacionar com você, porque o interesse público é intransponível".

$\mathrm{O}$ entrevistado pontua a necessidade de se ler corretamente o interesse público e rever essa interpretação "imobilizante", que, segundo ele, gera decisões insensatas e que prejudicam o próprio interesse público:

"Vou dar um exemplo dessa indisponibilidade do interesse público que é bem caricato: a Administração é condenada a fornecer um determinado medicamento e não é de medicamentos que está na relação, então eu preciso comprar o medicamento. Para comprar o medicamento, claro, para comprar com urgência, vou fazer uma pesquisa de preço. Então eu mando, preciso de três orçamentos, eu mando três ofícios, a três diferentes farmácias. Só duas respondem. Então eu mando de novo três ofícios. Um mês depois, mando três ofícios. Outros dois respondem. Mês a mês eu não consigo fechar três, no período de tempo. O juiz vai e me impõe uma multa, de mil reais por mês por atraso. A diferença de preço do medicamento é de dez reais. Em nome da indisponibilidade do interesse público eu estou causando um prejuízo ao interesse público. Isso não entra na cabeça do administrador."

Por outro lado, o entrevisto pontua que não é tão simples: existe um sistema, em que há o advogado público, o administrador e o Tribunal de Contas, e todos devem ter essa mesma postura.

No mais, o entrevistado apontou como importante o caminho da doutrina na reformulação desses conceitos, mas acredita que

\footnotetext{
"só que é uma coisa que ou vai vir de cima para baixo, numa postura em que se convença uma alta administração a adotar uma postura dessas ou vai sair pela capilaridade do sistema. Então isso vai ser mediante ações do tribunal de justiça buscando a redução do volume de contencioso e conversas com o tribunal de contas para lidar com essa questão."
}

Ao menos entre os entrevistados, não há uma leitura da supremacia do interesse público ou da indisponibilidade muito distante do que se apurou na doutrina mais recente, apesar de entenderem que, se tais conceitos não inviabilizam, ao menos limitam no tocante a renúncia de direitos.

\subsubsection{Previsão normativa da competência e dos limites do acordo}


A falta de normatização da realização de acordos foi uma questão unânime apontada por todos os entrevistados no âmbito da PGM-SP. As observações se dividiram em duas frentes: a falta de competência conferida por lei ao advogado público e a falta de parâmetros para o acordo.

Para uma das entrevistadas, a questão da competência clara para acordos é um dos óbices mais claros. Contudo, em outra fala, é sugerido quea lei não precisa balizar os termos do acordo, que já estaria limitado por outras condicionantes próprias do poder público: motivação, atendimento ao interesse público, fiscalização do Tribunal de Contas, publicidade, etc. O problema seria, portanto, de competência.

Outro entrevistado apontou que a competência dentro da PGM ainda é muito engessada, mantida desde a década de 80. Os Diretores detêm algumas competências, mas, como já são delegadas, não poderiam delegar mais.

Ademais, há áreas em que alguns entrevistados apontaram como de regulação necessária por lei autorizando fazer concessões, como é o caso da dívida ativa e do direito tributário, em que a remição do crédito tributário é reserva legal. Essa falta de autorização, nesses casos, bloquearia qualquer tentativa de acordo.

A mesma entrevistada, indagada sobre a possibilidade de realização de concessão de um valor em favor de particular, afirmou que "talvez em um ato de governo, capitaneado pelo próprio chefe do Executivo, desde que, claro, tivesse uma motivação válida".

De qualquer forma, o procurador que atua diretamente na condução dos casos e mesmo nos casos em que eles estão autorizados (como o parcelamento) tem essa preocupação com a autorização da lei.

Outro entrevistado apontou que os acordos precisam ter base legal com parâmetros pré-estabelecidos e competências definidas, além de bastante limitação: se o Município fosse credor, poderia envolver parcelamento. Se envolver deságio, teria que ser préestabelecido. Para o entrevistado, a autorização genérica já contida para o ProcuradorGeral não supriria nos casos que envolvesse renúncia de direitos.

Os acordos que envolvessem transação "na realidade, pra mim nada mais são do que adesões a situações legais pré-estabelecidas, com variáveis de flexibilidade quando a matéria de fato, você ainda não tem um valor apropriado”.

Mesmo nas questões controvertidas, em que o conteúdo do direito ainda não é certo, o entrevistado afirmou que “o Judiciário está aí para solucionar a controvérsia. Então 
o problema é que, se é controvertido, abrir mão de valores sem ter um posicionamento do Judiciário é muito inseguro, porque o Município estaria decidindo no sentido da renúncia" (posição com qual, como visto no capítulo 4, não concordamos plenamente).

Já para outro entrevistado, o Procurador-Geral poderia por ato próprio estabelecer algumas regras em relação a acordos, apesar de essa norma ainda não existir. Poderia sim haver um ato de hierarquia inferior, como instrução normativa ou portaria para normatizar a questão.

O que se sente em relação aos depoimentos é que há preocupação muito grande em acordos que permitem abrir mão de algum direito ou valor sem a respectiva previsão legal, apesar da previsão genérica do Procurador-Geral para transigir.

Outro ponto é que, mesmo nos acordos em que não há renúncia de direitos, é necessária que haja alguma parametrização normativa a fim de preservar a isonomia.

Nesse ponto, as entrevistas estão em consonância, com alguns desvios, daquilo que foi recolhido junto à doutrina.

\subsubsection{Adesão à lei}

Um dos entrevistados ressaltou a importância de não infringir a lei quando da elaboração de um acordo, mostrando-se contrário a eventuais medidas de compensação à infração à lei.

O exemplo dado foi o direito de construir, que possui parâmetros normativos bem definidos, impondo às construções determinadas características. Às vezes, há construções fora das normas e o Ministério Público, diante do fato consumado, sugere algumas medidas de compensação. Segundo o entrevistado, a dificuldade em aceitar tal proposta seria muito grande porque nesses casos o próprio Município deveria aplicar seu poder de polícia, e, nessa caso, abrir mão de um comando imperativo.

\subsubsection{Isonomia}

Nas entrevistas realizadas, a necessidade de previsão normativa de parâmetros para os acordos apareceu fortemente ligada à ideia de tratamento isonômico pela Administração Pública.

Contudo, um dos entrevistados entendeu que a questão do tratamento isonômico pode acabar retirando o caráter consensual da solução: 


\begin{abstract}
"Tem uma dificuldade grande de parametrizar, isso com certeza. Agora se você precisa parametrizar e tabelar, no momento que eu tabelei deixou de ser uma conciliação. Quando eu tabelei passou a ser direito, já que eu tenho que ser imparcial com todo mundo, se você se enquadra naquela condição, sou obrigado a concordar com você."
\end{abstract}

Não é o que aconteceria, contudo, em casos onde os parâmetros são mais flexíveis: "não pode ser um parâmetro muito certo. Tem que ser caso a caso. Eu tenho que pegar e olhar o caso e dizer a chance de sucesso. A jurisprudência aqui é nesse sentido, então eu vou perder. Não faz sentido eu prosseguir, vamos tentar conversar?”.

$\mathrm{Na}$ fala do entrevistado, restou claro que algumas situações não podem ser simplesmente homogeneizadas, pois os casos concretos guardam particularidades.

Na fala de outro entrevistado, a isonomia também está ligada à normatização, ainda que seja uma orientação genérica:

"No caso concreto é muito complicado. Inclusive, nós tivemos problemas com alguns convênios com organizações sociais, mais ou menos nessa linha. Secretarias que estavam com escassez de recursos, decidiam pagar para algumas e não pagar para outras. O que não deixa de envolver aí uma opção. Não é propriamente acordo, mas é uma opção. Você não pagar, acabou ferindo a isonomia e criando algumas dificuldades."

\title{
6.4.3.5. Discricionariedade e questões políticas
}

Para uma das entrevistadas, que entendeu que a prática de acordos fica muito condicionada a autorizações legislativas, a questão "acaba caindo um pouco no campo da discricionariedade política, então acaba se tornando uma decisão política também”.

Já para outra entrevistada, "aquela visão clássica do princípio da legalidade está sendo mitigada de alguma forma". Como exemplo, a entrevistada usa a negociação de precatórios que, em tese, precisaria de lei específica, mas foi utilizada a competência genérica do Procurador-Geral. "E foi o caminho que viabilizou para reduzir nossas demandas".

A rotatividade no poder, contudo, também foi apontada como um problema no âmbito da Administração. Um dos entrevistados narrou alguns projetos no sentido da adoção dos meios consensuais que não frutificaram porque houve troca de comando, não necessariamente contrariedade, mas sim porque "quando há troca de comando no Executivo, existe uma demora até a avaliação de alguns assuntos. E determinados assuntos devem envolver não apenas a Procuradoria, mas todas as secretarias". 


\subsubsection{Tamanho da máquina administrativa e descentralização das decisões}

Um outro problema identificado é a própria burocracia de uma estrutura do tamanho da Prefeitura de São Paulo, que também é bastante descentralizada.

Os prazos para que uma providência seja tomada no âmbito de uma negociação com o Ministério Público ou na apuração do cabimento de uma indenização normalmente são dilatados.

Uma questão que, segundo um dos procuradores, acaba dificultando um pouco a atuação da Procuradoria de forma mais ativa na composição de conflitos é que, dentro dessa estrutura descentralizada, os conflitos acabam eclodindo antes de chegar à Procuradoria. No campo contratual, por exemplo, é narrado que, quando o caso chega à Procuradoria, é porque já houve uma instância administrativa percorrida, em que houve a aplicação de uma multa contratual pela Secretaria responsável ou uma negativa a algum pleito do contratado. A questão já virá para a Procuradoria como uma ação para ser proposta ou defendida e seria delicado, do ponto de vista prático, mas também político revolvê-la no âmbito da Procuradoria.

A diferença em relação à responsabilidade extracontratual é que esta não teria uma instancia própria, o tratamento do conflito se iniciaria já na Procuradoria, o que facilita a condução consensual do caso.

\subsubsection{Possíveis efeitos negativos da adoção da solução consensual}

Um ponto que foi levantado não como um óbice, mas como um cuidado que se deve tomar ao adotar uma solução consensual são os possíveis efeitos negativos para o seu próprio objetivo.

Uma das entrevistadas cita a discussão sobre a possibilidade de compensação de tributos com precatórios:

\footnotetext{
"A gente discute muito se é vantajoso para o município de São Paulo fazer uma lei para compensar precatórios com tributos. Parece que no RJ foi feito e houve uma diminuição considerável na arrecadação. Porque as grandes empresas, que eram grandes devedoras foram comprando os precatórios e já uma coisa que gerou um prejuízo. Foi uma tentativa da Administração Pública em tentar resolver de uma forma alternativa, os dois
} 
conflitos, tanto a execução fiscal quanto o precatório, e acabou gerando um problema bem grande, porque houve uma diminuição da arrecadação" ${ }^{\text {"591. }}$.

Outro entrevistado aponta que a compensação de precatórios pode ter um efeito ruim para o planejamento orçamentário:

"[o Município de São Paulo tem] um comprometimento orçamentário com serviços públicos muito grande. Então ele tem que construir creche, transporte, você vê agora o problema do transporte público por conta da tarifa. Então se você começa a fazer essas compensações tributárias, não é que você perde orçamentariamente a receita, mas deixa de ingressar capital vivo. $\mathrm{E}$ isso teoricamente poderia dificultar muito a aplicação imediata dos recursos."

O problema de consequências negativas, contrárias ao propósito da medida, também foi apontado na prática dos PPIs, conforme já descrito, cuja frequência, se muito alta, pode gerar no contribuinte a sensação de que inadimplir o tributo e aguardar um programa de parcelamento é normal.

Há também a preocupação com o desenho de solução consensual legítimo e que evite contestações judiciais posteriores. Segundo uma das entrevistadas, "[os riscos] são inerentes à própria normatização. Toda solução consensual que envolva a Administração tem que ser muito bem pensada para que posteriormente a própria lei que instituir pode acabar sendo questionada, o que pode acabar gerando mais conflito para a Administração".

Outra entrevistada aponta

que o risco é de a lei não ser cuidadosa, não atender ao fim ao qual se propôs... então todo tipo de proposta de conciliação tem que ser muito bem pensada, não apenas para gerar o resultado desejado pela Administração, mas também para não ser objeto de questionamento judicial futuro e acabar prolongando um litígio que se desejava abreviado".

${ }^{591}$ É o caso de "comportamento oportunista" ou "falso positivo", apontado na pesquisa de Daniela Monteiro Gabbay e Luciana Gabbay Cunha, que advertem que os desenhos de soluções consensuais devem evitá-los, e assim os definem: "Por oportunismo entendemos nesta pesquisa os casos que não se enquadram no escopo do desenho de solução de conflitos (considerados nas Câmaras de Indenização da TAM e da Air France como "falsos positivos") e que, sem observarem as regras do jogo, buscam obter vantagens. Em um desenho extrajudicial de solução de conflitos, é importante que estas regras estejam claras, com a descrição dos critérios e casos de elegibilidade, evitando desvios e oportunismos" (CUNHA, Luciana Gross; GABBAY, Daniela Monteiro (coor.). O desenho de sistemas de resolução alternativa de disputas para conflitos de interesse público. Brasília: Secretaria de Assuntos Legislativos do Ministério da Justiça, 2011, p. 21, nota de rodapé 16$)$. 
Já no âmbito judicial, um dos entrevistados apontou que se valer de uma prática consensual sistemática não tem efeitos negativos significantes. "Pelo contrário. Se eu puder tirar do Judiciário, simplifica. Não é nem uma questão burocrática. Burocraticamente deixar no Judiciário talvez seja mais simples. Deixa entrar com a ação, porque alguns não vão entrar com a ação".

Para o entrevistado, adotar uma postura mais consensual e de menor resistência torna, inclusive, a litigância mais consistente:

\begin{abstract}
"quando você cria uma cultura de que quando você contesta, você contesta com razão, nem que muitas vezes seja, os juízes sabem disso, você tem uma determinada orientação nesse sentido, eu acho que você entra moralmente em uma posição melhor. (...) quando você começa a contestar firme, você fala assim: 'poxa, se eles estão resistindo, alguma coisa tem, tem que ter alguma razão' ".
\end{abstract}

\title{
6.4.3.8. Possível falta de estímulos pessoais?
}

Uma hipótese levantada na discussão em banca do projeto que originou a presente dissertação foi a possível falta de estímulos pessoais para os procuradores adotarem uma postura de menor resistência e maior consensualidade. Contudo, as entrevistas revelaram que essa não parece ser uma questão que influencie a adoção de uma prática consensual ou não.

Sobre o tema, uma das entrevistadas se pronunciou: "Acho que muito pelo contrário. Para o Procurador, quanto mais acordo melhor. Quanto mais pudermos evitar uma demanda judicial melhor. É mais uma questão técnica de não ter viabilidade jurídica para viabilizar o acordo é o maior problema".

Outra afirmou que

“para a gente é um princípio, para a gente já é algo que deve ser estimulado. Eu não sei se eu seria simpática à ideia de um tipo de reconhecimento. Mas uma orientação sim, antes de um ajuizamento, mandar carta para os devedores antes de entrar com uma ação de execução fiscal. Acho que a padronização desse tipo de conduta sim, mas... envolve outro projeto grande, que é essa questão de estímulo do servidor, mas não sei se associaria esse tipo de conduta a um tipo de bonificação. Não vejo o porquê."

Outras entrevistas realizadas também tiveram respostas semelhantes em relação a essa hipótese.

\subsubsection{Cultura de resistência}


Um dos problemas apontados por um dos entrevistados ligado à Procuradoria Judicial, a adoção de um modelo de condução dos casos que envolva mais abertura para o consenso e mesmo para se formar um ambiente de litigância mais racional é necessário superar uma cultura de resistência existente tanto na advocacia pública quanto na própria Administração.

Uma das medidas destacadas na criação do procedimento de indenização extrajudicial foi separar a sua condução dos procuradores que atuam diretamente nos processos judiciais. Segundo o entrevistado:

\begin{abstract}
"Tem essa dualidade, está separado dessa forma. Eu sempre defendi que ela ficasse separada aqui. Porque de fato eu acho que se nós passarmos isso para um procurador que não está ligado ao contencioso a tendência é de uma flexibilização dos critérios, enquanto fica difícil para a pessoa ao mesmo tempo que está escrevendo no processo dizer: "aqui tudo bem, eu vou conceder". No próximo ela pega um mandado que ela tem que fazer uma contestação pesada para afastar indenização. Fica uma esquizofrenia complicada."
\end{abstract}

Um apontamento feito pelo mesmo entrevistado é no tocante que, para mudar a cultura de resistência, é necessário também ter um bom gerenciamento de informações, tanto em relação aos focos de litigância quanto em relação aos possíveis cenários da decisão judicial. O monitoramento de informações é uma solução para um problema sistêmico:

\footnotetext{
"é um caminho que tem que subir de nós que estamos no contencioso, para reduzir o contencioso. Só que aí a gente peca pela falta informação, ter um sistema em que eu possa dar um conforto maior para quem tem que decidir que esse tipo de demanda eu vou perder, com uma certeza muito grande.

(...)

Eu não tenho a informação. O sistema, a estrutura, ela não está buscando isso, ela é toda montada para fazer resistência.

Nós estamos fazendo muito investimento em sistemas agora e a ideia é de que a gente possa ter informação gerencial. Então para esse tipo de caso não adianta discutir, a gente vai perder, reconhece."
}

Prossegue o entrevistado: “Com isso, você consegue provocar o administrador. Só que eu não consigo falar para ele hoje que está causando prejuízo com a sua conduta, porque eu não consigo mostrar. Eu posso pegar pontualmente, um caso. E quando eu tenho um caso eu convenço".

Questionado sobre qual seria o maior óbice para a adoção de um sistema que superasse essa cultura de resistência, o entrevistado aponta que "seria de vontade. É 
assumir o risco. E aí, é claro, a causa dessa inércia de decisão pode estar nessa falta de informação precisa, do futuro daquela demanda se ela for judicializada".

\title{
6.4.3.10. Controle da Administração Pública
}

O controle por órgãos como o Ministério Público e o Tribunal de Contas também foi mencionado em entrevistas como uma possível explicação para a pouca utilização dos meios consensuais. Um dos entrevistados apontou que

\begin{abstract}
"da mesma forma que você tem a pessoa que se esconde, você tem a pessoa que se protege, que na verdade, a gente sofre com os auditores do tribunal de contas e é uma coisa meio inquisitorial.

Então é uma situação que você fica em uma postura... "Por que você fez isso?".

E para você ter uma ideia, não somos só nós, é o Ministério Público, também. O poder que o Ministério Público tem de provocar a administração é muito grande. Então uma questão como essa pode simplesmente cair no Ministério Público do patrimônio e pode usar como bandeira para atacar a administração. Então tudo isso é muito complicado."
\end{abstract}

Contudo, os entrevistados dizem que são poucos os casos em que o Tribunal de Contas questionou um acordo feito.

\begin{abstract}
"Se o tribunal de contas entender que determinado acordo feito está nulo ou etc., ele vai responsabilizar alguém e vai mandar pra cá. Muito pouco.

(...)

É muito pouco, mesmo. Vem normalmente com questão de dívida ou quando se configura uma improbidade. Que aí muda de figura, saí da conciliação e caímos na ilegalidade. Não é esse o caso. Então assim, muito pouco. Olha, não dá dois por ano.”
\end{abstract}

\section{Outro entrevistado expressa a mesma preocupação:}

"Não tenho até agora notícia de interferência, mas eles [Tribunal de Contas] teriam competência para interferir, com certeza. Esse é um dos problemas que lhe falei em relação a essa renúncia de direitos que envolvem capital público. Você imagina que os procuradores passam a fazer acordos com renúncia de créditos públicos, isso com certeza o tribunal de contas poderia intervir, inclusive o próprio Ministério Público."

$\mathrm{Na}$ entrevista, ainda foi relatado:

\footnotetext{
"Teve um caso envolvendo aqui a São Paulo transportes, que eu não me lembro exatamente dos detalhes, em que parece que fizeram um acordo para pagar uma dívida contratual, sem ação judicial. Mas foi um acordo considerado escandaloso, que teria beneficiado determinada empresa em detrimento de outras, sem um fundamento muito claro para isso. E isso gerou um inquérito civil.”
}

Também foi expressada a preocupação com os advogados individuais: 


\begin{abstract}
"Inevitavelmente, por mais confiança que se tenha, por mais controle que se possa exercer, com certeza surgiriam alguns casos ai, ainda que não fossem de corrupção, mas de imprecisões, de questionamento a respeito dos critérios, e a responsabilidade com o contribuinte não permite isso".
\end{abstract}

\title{
6.4.4. Sobre o envolvimento de terceiro imparcial
}

A ideia de um procedimento consensual que envolvesse um terceiro imparcial foi aventada nas entrevistas, mas houve apenas uma posição de destaque sobre o tema.

Um dos entrevistados, ligado ao Departamento Judicial, acredita que seria muito difícil trazer alguém que conseguisse manter a imparcialidade necessária para um mediador:

\begin{abstract}
"Porque interfere muito nisso o conhecimento da administração. E aí, se é um mediador que conhece a administração ele começa a perder a sua imparcialidade. Então não adianta trazer alguém que foi servidor do município, servidor do estado, porque isso vai atrapalhar e vai gerar na outra parte uma questão de suspeição. Eu acho que fica muito complicado."
\end{abstract}

Há preocupação também com a lisura conduta do eventual mediador ou com a aparência da lisura: "Se o mediador sair um pouquinho da linha dele de buscar a solução e começar a conduzir uma solução, essa nuvem [corrupção] já pode surgir. O trabalho do mediador eu acho bastante difícil, principalmente por conta disso".

No mais, o mediador teria um trabalho extra em documentar porque determinada solução foi adotada em um caso e não em outro:

\footnotetext{
“Toda a estrutura, de novo eu estou caindo na questão da história da indisponibilidade do interesse público, o quanto esse pessoal vai ter que documentar o que está fazendo, os critérios que ele adotou, para concordar em quinze nesse caso e não concordar em quinze no outro caso. Para afastar a questão de que ele pode estar suspeito. Eu acho muito difícil. É uma cultura de corrupção e de medo da corrupção. Então eu acho que seria muito difícil."
}

Há, ainda, a desconfiança na capacidade de o conciliador em conduzir imparcialmente eventual sessão e, ao mesmo, resolver o problema da evidente disparidade de forças entre a Administração e o indivíduo:

"Eu acho que com o mediador não vai ser produtivo. Até porque o que acaba acontecendo é que você tem uma diferença de posições muito grande. A administração 
tem muito mais poder do que a outra parte, então é difícil para o mediador equilibrar isso aí sem começar a defender. Aí começa a entrar o 'princípio do tadinho', 'você pode dar mais'. E aí eu acho que não vai ‘colar'. E aí vai gerar o que? Resistência.”

Registrou-se posição no sentido de que se o mediador atuasse para auxiliar a parte a se articular melhor estaria fugindo do conceito de "facilitador de solução": "Acho muito difícil. Ele vai agir como advogado da parte e não como mediador".

\subsubsection{Alguns caminhos para o tratamento de conflitos no âmbito da PGM}

As entrevistas indicaram caminhos para o futuro do tratamento dos conflitos no âmbito da PGM-SP, alguns que, segundo alguns entrevistados, já são projetos elaborados ou em elaboração, mas não implementados:

1) Ampliação do que foi chamado "contencioso administrativo" (a exemplo do pedido administrativo de indenização), para alguns pleitos dos administrados que possam ser reconhecidos administrativamente, em que não há renúncia a uma posição jurídica prédefinida;

2) Criação de monitoramento para identificação dos pontos geradores de litígio, a partir das ações judiciais em que o Município de São Paulo figura como réu e também dos pedidos administrativos, com objetivo de elaborar um diagnóstico constante das causas desses conflitos e propor medidas administrativas com base no poder de polícia para prevenção de litígios;

3) $\mathrm{Na}$ mesma linha, monitoramento de posicionamentos jurisprudenciais para propor mudanças na atuação do administrador;

4) Instalação de câmaras de conciliação para evitar litígios em determinadas situações que envolvam "compensações", como controvérsias contratuais, com o objetivo de preservar relações e evitar prejuízos mútuos causados por litígios. Essas câmaras poderiam ser instaladas tanto no âmbito da PGM quanto nas próprias Secretarias, com a participação de procuradores. 
5) Avaliação prévia da administração de pedidos administrativos e/ou judiciais que envolvam prestação serviços públicos ou fornecimento de medicamentos/tratamentos, a fim de verificar a possibilidade de atendê-los independentemente do prosseguimento da ação.

\subsection{Análise: há uso de meios consensuais no trato de conflitos no âmbito da PGM-SP?}

Existem, na PGM-SP, práticas que têm como objetivo prevenir ou compor conflitos extrajudicialmente. Os próprios entrevistados, contudo, relutaram em classificá-las como "meios consensuais", o que podemos atribuir a dois fatores: (i) à visão de que a Administração se posiciona como autoridade decisória em relação aos instrumentos de reconhecimento; (ii) a ausência de margem de negociação para o particular, em relação a instrumentos como a "conciliação" de precatórios ou os parcelamentos de débito (na modalidade de PPI ou no parcelamento ordinário).

De fato, algumas das práticas narradas (pedidos administrativos de indenizações e de benefícios-acidentários) têm estrutura que mais se assemelha à adjudicação, em que o interessado tenta, por meio de provas e argumentos, obter uma decisão favorável. No entanto, quem está decidindo pelo atendimento ou não do pedido não é um terceiro, e sim a própria parte devedora (Administração Pública).

É certo também que, em tais casos, a Administração faz sua análise com base na Lei que, como já vimos, é o único parâmetro possível. Contudo, em casos de responsabilidade civil, os parâmetros legais não dão imediatamente a resposta para qualquer caso, sendo necessária que seja feita uma interpretação pela própria Administração, com suporte na jurisprudência. Até por esse motivo, o regulamento do pedido administrativo de indenização não é taxativo, comportando uma análise ampla de fato e de direito pelas autoridades competentes. Como realçado por um dos entrevistados, a chance de perder uma ação judicial é levada em conta na decisão de deferir ou não o pleito.

O que se pode dizer de tais mecanismos é que eles são (i) desjudicializantes, (ii) não adversariais e, a princípio (iii) também não seriam adjudicatórios, pois a decisão não parte de um terceiro.

No mínimo, poderia ser considerado um meio autocompositivo de prevenção de conflitos, pois é a própria Administração que analisa o direito do requerente antes de haver 
uma contraposição de condutas entre eles e, consequentemente, a instauração de um conflito. Quando o direito é reconhecido pela própria devedora, evita-se o conflito.

Resta saber se o fato de a Administração decidir pelo critério legal, a partir de um procedimento, e a ela própria caber a decisão final, permitiria conceituar o mecanismo como meio consensual.

Cremos que sim, porque o requerente tem, nesse instrumento, acesso a um canal para dialogar diretamente com a Administração e a possibilidade de constantemente influir na sua decisão, através de fatos, provas e critérios. O processo administrativo que é instalado também propicia um diálogo, ainda que formal, entre as partes. Por outro lado, não é possível enquadrar esse instrumento no conceito de "consensualidade administrativa" adotado, que implicaria "quaisquer acordos de vontade entre as partes", o que não seria o caso.

Além disso, a diferença de poder, contudo, é grande, pois, como visto, a decisão cabe à Administração e a simples possibilidade de uma ação judicial (normalmente de baixo valor) não é instrumento de barganha forte o suficiente em favor do requerente. Aliás, nem se poderia falar em "barganha" propriamente, mas talvez em influência na construção de uma solução dentro das molduras legais.

Um grau maior de consensualidade é observado nos Termos de Compromisso firmados com os Ministérios Públicos, o que pode ser atribuído a dois fatores: (i) as matérias sujeitas ao instrumento comportam em si maior espaço para negociação, pois muitas vezes não têm soluções legais claras (como o caso dos meninos-engraxates, narrado no item 4.1); (ii) o diálogo se dá entre instituições de mesmo porte (Ministério Público e Prefeitura de São Paulo).

Os acordos com termos limitados (negociação de precatórios, parcelamentos e PPIs), ainda que sejam praticamente uma adesão, têm um caráter consensual na medida que dependem do encontro das vontades: da Administração, em propor (ainda que de forma ampla e geral) e do particular, em aceitar. Contudo, para a Administração, uma vez lançados os termos do acordo, não é possível a recusa, pela própria atenção à isonomia.

No entanto, ainda são muito poucas as práticas institucionalizadas e sistematizadas na PGM-SP para esse tratamento diferenciado, considerando o universo de conflitos em que a Administração municipal se insere.

Na condução judicial dos casos, não há nenhum tipo de instrumento ou prática que viabilize a os acordos em Juízo em casos controversos, pela simples análise da chance de vencer judicialmente ou não. 
Nos casos de ações ajuizadas ou a ajuizar, em que a Procuradoria percebe que a Administração cometeu um erro (ou seja, questões sobre as quais não paira controvérsia), se há a opção por não resistir (o que nem sempre ocorre, segundo as entrevistas realizadas no setor Judicial) normalmente a solução não se dá via acordo, mas sim mediante revisão de atos administrativos (como cancelamento de multa), não propositura da ação ou não interposição de recurso.

Mesmo nesses casos, notou-se pelas entrevistas que a postura de resistência tanto por parte do administrador quanto do advogado público ainda é muito forte, e essas medidas de não resistência não são tomadas na medida que deveriam.

Não foi notada nenhuma prática de composição de conflitos que se valha da atividade de terceiros imparciais (conciliação ou mediação), o que pode ser atribuído a dois fatores: (i) mais uma vez, à visão de que a Administração se coloca como autoridade decisória; (ii) à falta de crença na influência que um terceiro possa ter na composição com a Administração Pública, seja em termos da efetividade da sua atuação para a composição do conflitos, seja em termos de dificuldade na preservação da imparcialidade.

Em um contexto em que não é uma prática sistematizada a realização de acordos em geral, em questões judicializadas ou não, fora dos casos já regulados, faz algum sentido não serem localizadas práticas em que haja intermediação por terceiro.

Contudo, caso haja um desenvolvimento sistemático da realização de acordos pela Administração Pública municipal, acreditamos que as observações não invalidam a possibilidade (ou até necessidade) da participação de um terceiro imparcial que, ainda que tenha conhecimento sobre o funcionamento da Administração, não esteja a ela ligado, com o objetivo de assegurar sua imparcialidade. Nota-se que há programas de tratamento consensual de conflitos envolvendo entes públicos que são cuidadosos em manter a mediadores imparciais (havendo inclusive discussões sobre como assegurar essa imparcialidade) e até autoridades judiciárias exercendo supervisão (vide item 5.1.1.), a fim justamente de minimizar efeitos indesejáveis decorrentes da diferença de poder entre as partes $^{592}$ e também exercer sua função mais clássica, que é a facilitação do diálogo e o apoio, seja mais ou menos propositivo na formulação de opções para composição do conflito.

592 Cf. novamente: ASPERTI, Maria Cecília de Araújo. Meios consensuais de resolução de disputas repetitivas: a conciliação, a mediação e os grandes litigantes do Judiciário. Dissertação (Mestrado) Faculdade de Direito da Universidade de São Paulo. São Paulo, 2014, p. 94-95 e notas de rodapé n. 263 e 264. 
De qualquer forma, as percepções obtidas nas entrevistas a respeito da condução de meios consensuais por terceiros imparciais suscita uma séria de questões sobre as particularidades deste terceiro quando o caso envolver a Administração Pública, como: (i) qual o grau de conhecimento que ele deve ter sobre o funcionamento da Administração e como obtê-lo; (ii) se é adequado ou não utilizar ex-servidores públicos em geral ou, especificamente, ex-advogados públicos; (iii) qual deve ser o papel do terceiro imparcial, se eminentemente promotor do diálogo ou, por outro lado, garantidor de simetria de informações.

De qualquer forma, notou-se que os poucos mecanismos consensuais existentes se dão por negociação direta entre a Administração e a outra parte.

\subsection{Análise: causas que influenciam o grau de utilização do uso de meios consensuais na PGM-SP}

A partir das entrevistas, foi possível confirmar uma série de limitações constantes na literatura sobre o tema como sendo preocupações reais dos advogados públicos, e que influenciam a opção pelo uso ou não de meios consensuais. Tentaremos agora sistematizálas:

\section{1) Necessidade de regulamentação da prática de acordos}

A necessidade de regulamentação das possibilidades de acordo aparece como uma constante na fala dos entrevistados. A questão está imbricada com outros dois temas: o do tratamento isonômico e o da preocupação com a responsabilização individual do agente. Existe grande resistência em se realizar acordos sem suporte normativo, com receio de se caracterizar improbidade administrativa.

A previsão em normas da possibilidade de acordo, bem como a parametrização dos seus termos, parece ser um passo essencial para o desenvolvimento de uma prática de solução consensual de conflitos sistematizada. Aparentemente, a advocacia pública espera essa regulação porque: (i) a parametrização resolveria problemas de tratamento isonômico, possibilitando que todos os particulares em conflito com a Administração em situações semelhantes fossem submetidos aos mesmos critérios de acordo, mais ou menos abertos, a depender da matéria envolvida; e (ii) a previsão dos critérios balizadores do acordo 
resguardaria a responsabilidade pessoal dos procuradores, pois uma de suas grandes preocupações é o risco de celebrar acordos "prejudiciais" ou que acabem implicando “concessões" pelo Município sem apoio normativo.

Também entre cargos de diretoria dentro da PGM defende-se a regulação, inclusive para resguardo dos procuradores que atuam individual e diretamente nos casos, entendendo-se que, em uma possível normatização, as possibilidades dos acordos por eles firmados sejam bastante limitadas.

Outra conclusão que se pôde tirar é que o estabelecimento de um procedimento para gerar a decisão sobre a realização ou não de um acordo ou reconhecimento de direito auxilia em garantir segurança jurídica para o ato em si e para seus agentes. É o que se nota, por exemplo, do Decreto n. 52.164/2011, que estabeleceu um procedimento simples para balizar a celebração de Termos de Compromisso com o Ministério Público, mas que confere segurança ao tomador da decisão, por exigir um parecer técnico e outro jurídico a respeito da proposta. Necessário apontar, contudo, que o procedimento não pode ser tal que prejudique a celeridade da medida.

Por outro lado, há preocupações dos procuradores com (i) a qualidade dessa regulamentação, com (ii) as suas possíveis consequências e com (iii) a sua validação perante os outros órgãos do Poder Público.

As preocupações com a qualidade advêm da necessidade de resguardar os acordos realizados sob determinada regulação de posteriores questionamentos judiciais. A preocupação com as consequências vem do desejo de evitar comportamentos oportunistas e falsos positivos, como já descrito no item 6.4.3.7, ou, ainda, prejuízos ao interesse que se quer tutelar com as medidas (como hipóteses de queda na arrecadação no caso estímulos premiais ao parcelamento muito frequentes).

A preocupação com a validação diz respeito à busca apoio político à regulação adotada, com adesão dos órgãos da Administração Pública à proposta, que, afinal, é quem acabará sendo afetada pelas medidas. Evitam-se, assim, medidas que partam apenas da Procuradoria, sem o envolvimento dos demais órgãos da Administração Pública (Secretarias e a própria chefia do Executivo).

Talvez por isso que, não obstante tenha se apurado que para viabilizar a realização de acordos bastaria a norma de competência (exceto nos casos de renúncia), a competência para "transigir ou firmar acordos" do Procurador-Geral não seja utilizada de forma autônoma com frequência. Também por isso que um dos entrevistados defendeu também a 
regulação em lei, da possibilidade de acordo, não obstante já existir competência legal para tanto.

Como visto, iniciativas notáveis como a negociação de precatórios e o pedido administrativo de indenização, apesar de terem se baseado nas competências do Procurador-Geral, contaram com a expedição de Decreto do Prefeito. Não contaram com a participação do Legislativo, mas contaram com a validação do Executivo.

Por outro lado, um dos entrevistados suscitou a discussão de que onde virá a superação da falta de regulação: ou parte da própria advocacia pública, pressionando os outros órgãos para a regulamentação da matéria, ou partirá de cima para baixo, das esferas mais altas do Executivo ou mesmo do Legislativo. A vontade política, os ciclos de alternância do poder, e abertura das esferas mais altas (Prefeitura e Secretarias) ao tema também parece ser um fator decisivo na regulação da matéria.

2) Compreensões sobre os princípios da supremacia e da indisponibilidade do interesse público

Em geral, os entrevistados não apresentaram compreensões restritivas sobre tais princípios. Nas oportunidades em que foi invocado o princípio da indisponibilidade, na verdade, ele foi relacionado com outras limitações, como a necessidade parâmetros objetivos, a competência clara para o ato, e a garantia da isonomia.

Há destaque, contudo, para uma das posições apresentadas em entrevista que relaciona a indisponibilidade com a restrição de concessão de interesses, adotando postura contra um modelo consensual pautado em renúncias e "concessões mútuas" por parte da Administração. Segundo o entrevistado, essa seria uma postura de respeito com o contribuinte.

Contudo, nota-se que, apesar dessa posição restritiva, nenhum dos entrevistados adotou uma visão imobilizante sobre a indisponibilidade do interesse público, como princípio que evitasse qualquer composição consensual pela Administração Pública ou justificasse qualquer postura de resistência.

Por outro lado, o universo pesquisado não é suficiente para afirmar que na Administração Pública haja uma visão renovada desses princípios. Como já destacado, a atuação do advogado público faz parte de um sistema em que suas decisões dependem também do entendimento do próprio Administrador e dos órgãos de controle, 
especialmente o Tribunal de Contas. E, segundo o apurado nas entrevistas, não se tem uma perspectiva otimista da visão desses outros autores sobre o tema.

Todavia, um dos entrevistados mostrou-se esperançoso com o papel da doutrina em desenvolver contornos mais claros sobre esses princípios para que a própria advocacia pública consiga sustentar junto aos demais órgãos da Administração soluções consensuais que militem, inclusive, a favor do "interesse público".

\section{3) Cultura de resistência}

Aliada à compreensão sobre os princípios de supremacia e indisponibilidade de interesse público, as entrevistas revelaram a existência de uma cultura de resistência, especialmente nas causas localizadas no Setor Judicial. Não se tem ao certo com clareza se é a concepção teórica que determina a cultura, ou se há um desejo de resistência, por questões práticas, que busca fundamento nos conceitos teóricos.

De qualquer forma, no setor Judicial, a cultura de resistência (que não é apenas dos procuradores, mas também do próprio Administrador) pareceu ser um fator que interfere muito na adoção de práticas consensuais ou mesmo não litigiosas. Como destacado por um entrevistado ligado ao setor, um passo antes de se adotar um sistema que se valha mais da prática de acordos é superar a cultura de resistência quando a Administração não tem razão.

Ainda há, pelo que se constatou, posturas em que se contesta sem razão, o que é determinado por uma série de fatores, entre eles, novamente, a preocupação do advogado atuante no processo com sua responsabilidade pessoal com a condução do caso e com os prazos a serem cumpridos e, ainda, a própria prática contenciosa e o condicionamento à reação defensiva.

\section{4) Dificuldades práticas}

Outra série de óbices identificados foram as dificuldades práticas decorrentes da própria estrutura da Administração Pública.

Uma consideração, que não é propriamente um óbice, mas um possível fator de desestímulo, é que a Administração conta com uma estrutura muito grande, e a obtenção de 
informações relevantes para a solução de um caso muitas vezes pode demorar, mais do que desejam os particulares, e mais do que desejam instituições como o Ministério Público.

A criação de uma Coordenadoria de Mandados e Acompanhamento de Inquéritos Civis foi uma das medidas tomadas pela PGM-SP para reunir e organizar informações e, assim, agilizar as respostas que devem ser dadas.

Por outro lado, a descentralização das instâncias administrativas para lidar com os problemas e a falta de um canal centralizado e especializado em solução de conflitos também parece ser um problema. Como aferido em uma das entrevistas, no campo contratual, os conflitos já chegam à Procuradoria em um grau de litigiosidade mais agudo, porque já tiveram uma escalada no órgão contratante correspondente.

Contudo, não se sabe se nos órgãos esses conflitos contratuais recebem tratamento adequado, com aplicação correta de técnicas de negociação, no intuito de evitar prejuízos.

Uma câmara destinada a esses conflitos, como se aferiu das entrevistas ser uma possível perspectiva, ajudaria a organizar e adequar o tratamento de controvérsias. A criação desses órgãos específicos para solução de controvérsias, com aplicação adequada de técnicas de composição consensual, e com consciência das limitações envolvidas, configura uma boa alternativa, inclusive já positivada por meio do art. 145 do recémaprovado Código de Processo Civil, sendo necessário, a partir de agora, o exercício da vontade política em implantá-la. 


\section{CONSIDERAÇÕES CONCLUSIVAS}

A presente dissertação teve como objetivo investigar como o nosso ordenamento recebia a utilização de meios consensuais de solução de conflitos pela Administração Pública.

Em primeiro lugar, buscou-se demonstrar duas frentes de desenvolvimento de ideias, em duas áreas diferentes do Direito, que propiciam um cenário favorável para o desenvolvimento de práticas consensuais pela Administração Pública.

De um lado, temos um ambiente de fomento aos meios alternativos de solução de conflitos (ADRs), que se iniciou na década de 1970 nos Estados Unidos, em razão das dificuldades que a adjudicação estatal vinha apresentando para a solução célere e efetiva dos conflitos. O movimento resultou na criação e recuperação de inúmeros métodos de solução de conflitos, consensuais e adjudicatórios, como a mediação e arbitragem, bem como na forma de organização desses meios em "tribunais multiportas" ou em "centros comunitários de solução de conflitos”. Originou, ainda, práticas profissionais nas áreas pública e privada, como a mediação familiar e a arbitragem comercial. O movimento repercutiu no tratamento de conflitos envolvendo entes públicos nos Estados Unidos, com a previsão expressa no Administrative Dispute Resolution Act de uso de meios alternativos pelas agências estatais. No Brasil, o movimento influenciou a consideração dos meios alternativos, consensuais ou não, nas pautas do Poder Judiciário, o que culminou, em 2010, com a aprovação da Resolução n. 125/CNJ que instituiu a "Política de Tratamento Adequado de Conflitos", e, mais recentemente, no foco dado ao recém-aprovado Código de Processo Civil dado a esses instrumentos. Essas mudanças ensejaram, inclusive, a revisitação dos conceitos de acesso à justiça e jurisdição, a fim de considerar uma perspectiva em que a utilização adequada de meios alternativos fosse abarcada (i) como manifestação de acesso à justiça, inclusive como complemento legítimo e até mais adequados do que a adjudicação estatal, e (ii) em um conceito mais amplo de jurisdição.

De outro lado, o Direito Administrativo também passou por mudanças, reformulando e recontextualizando antigos dogmas, a fim de estabelecer uma Administração Pública mais paritária e menos calcada exclusivamente em atos unilaterais. Um dos princípios que sofreu contestação na doutrina mais recente é a "supremacia do interesse público", que foi tida como inoperável ante (i) a dificuldade, em nossa sociedade fragmentada, de se estabelecer um interesse público único, e (ii) ante a sua 
incompatibilidade com o atual postulado da proporcionalidade, que dirige nosso Direito Constitucional e demanda ponderação de todos os interesse, coletivos ou privados, implicados em uma situação com concreta. Essa revisão conceitual, juntamente com uma série de reformas legislativas, possibilitou o início do estabelecimento de uma “Administração Pública consensual”, onde, em sentido amplíssimo, instrumentos de participação social, instrumentos contratuais, outros acordos de vontade, e soluções consensuais passaram a serem previstos como alternativas aos contratos administrativos tradicionais, à solução unilateral de conflitos e à imposição de prerrogativas sancionadoras.

Estabelecido esse panorama, tentou-se responder às três perguntas formuladas, o que ora se sistematiza:

(1) É possível perante nosso Direito a adoção de meios consensuais antes ou durante ou instauração de processo judicial para resolução de conflitos que envolvam a Administração Pública como parte? Ou, havendo controvérsia, a questão deve necessariamente ser submetida à via judicial?

A hipótese levantada foi de que não há óbice jurídico que impeça a Administração Pública de adotar meios consensuais, o que, de fato, foi confirmado. Os eventuais óbices gerais à adoção de meios consensuais pela Administração Pública, que seriam os princípios da supremacia e da indisponibilidade do interesse público, não mais se sustentam nesse sentido.

O princípio da supremacia do interesse público, como já dito, teve sua operacionalidade no contexto social atual fortemente contestada. Por outro lado, mesmo que se considerasse algum conteúdo operacional ao princípio, ele não guardaria vínculo nenhum com a adoção do meio adequado de solução de conflitos.

O segundo dogma, o da "indisponibilidade do interesse público" também teve de ser relido ante as recentes transformações sociais e constitucionais. Concluiu-se que não existe, de fato, uma "indisponibilidade" ampla e irrestrita do "interesse público", até porque essa é uma cláusula geral de conteúdo dificilmente identificado. O que existe sim é uma finalidade pública específica a cada ato da Administração, como o atendimento a determinado interesse coletivo ou a algum direito fundamental, que não pode ser desviada. Assim, mantendo essa finalidade, eventual conflito pode ser composto de forma consensual desde que ela seja preservada.

Dessa forma, não haveria mais o que se falar em impossibilidade de adoção de meios consensuais ante a reformulação desses dois princípios. Também se demonstroue 
que, além de os meios consensuais não necessariamente resultarem em "disposição" do bem ou direito da Administração, podem ainda servir como instrumentos eficazes para atingir o interesse público.

(2) Em caso de resposta positiva à questão anterior, as especificidades normativas que regem a atuação da Administração Pública impõem limites à adoção de meios consensuais?

A hipótese era de que a Administração Pública, devido ao seu regime próprio de Direito Público, apesar de poder engajar em soluções consensuais de conflitos, estaria sujeita a limitações, o que de fato foi confirmado. Além da necessária vinculação da solução consensual ao interesse público envolvido, outras limitações foram consideradas.

A primeira ordem de limitações diz respeito à necessidade ou não de previsão legal para adoção do meio consensual, tendo-se concluído que (i) não é necessário autorizar expressamente o uso de um meio consensual válido pela Administração Pública (como a conciliação ou a mediação), ressalvados entendimentos que entendem necessária a previsão legal quando o acordo envolver "atos de disposição"; (ii) o uso do meio consensual não depende de regulação por lei ou ato infralegal que dê parâmetros genéricos de seu conteúdo, pois, na sua ausência, o que importaria é atender à finalidade pública envolvida; (iii) a existência norma conferindo competência ao agente público para celebração de acordos é obrigatória, a fim de garantir a validade do próprio ato administrativo resultante do meio consensual.

A segunda limitação diz respeito ao critério para composição do conflito pela Administração, que não pode ser outro que não o jurídico. Isso, contudo, não significaria o engessamento das práticas consensuais, pois a Lei muitas vezes não traz a solução exata, sendo aberta a interpretações. Há de se considerar, ainda, os diferentes níveis de vinculação legal da Administração, havendo casos em que a margem de discricionariedade é maior, e o conteúdo do ato pode ser preenchido consensualmente.

A terceira limitação diz respeito à necessidade de guardar isonomia entre os particulares que se situarem em condições semelhantes, de forma que uma solução consensual não pode ser adotada para apenas um deles, devendo-se dar oportunidade igual a todos de celebrar o mesmo acordo. Isso não ocorreria, contudo, em questões pouco vinculadas, mais ligadas à discricionariedade, com critérios elementos menos objetivos de identificação com casos semelhantes. 
A quarta, aplicada aos casos de acordo em juízo, diz respeito ao pagamento por precatórios. Concluiu-se que a celebração de acordos judiciais com pagamento imediato não violaria a garantia da ordem de precatórios se realizados durante a fase de conhecimento, pois, nesse caso, estar-se-ia realizando, na verdade, um reconhecimento administrativo do direito e não jurisdicional. Inclusive, a medida seria necessária para que não se violasse a isonomia entre aqueles que ingressaram em juízo para ter seu direito atendido e aqueles que o tiveram espontaneamente na via administrativa. Contudo, notouse que a jurisprudência do STF parece caminhar em sentido contrário.

A quinta limitação é a necessidade de conferir publicidade aos meios consensuais de solução de conflitos que envolvessem a Administração, em contraposição ao sigilo normalmente apontado como uma vantagem das ADRs. O sigilo, todavia, deveria, em regra, ser mantido em relação às reuniões privadas, como forma de garantir a imparcialidade.

(3) A Administração Pública, em sua atuação concreta, lança mão de meios consensuais de solução de conflitos? Ou os encaminha exclusivamente ao Judiciário? Quais os razões para uma ou outra conduta?

A hipótese levantada foi que, na prática, há pouco ou nenhum tratamento consensual de conflitos no âmbito da Administração Pública. As razões inicialmente aventadas para tal suposição seriam a adesão dos advogados públicos a concepções tradicionais de Direito Administrativo, além do fato de que a falta de regulação do tema não conferiria segurança jurídica suficiente para a composição consensual de conflitos.

A partir do estudo de caso realizado na Procuradoria-Geral do Município de São Paulo, a hipótese foi parcialmente confirmada, confirmando-se que há pouco uso de instrumentos consensuais, considerando globalmente a realidade dos conflitos em que se insere a Administração. Contudo, são utilizados instrumentos interessantes, regulamentados no âmbito da Procuradoria, com vistas a reduzir a litigiosidade e conferir alternativas aos particulares para reconhecimentos de direitos, como é o caso da procedimentalização dos Termos de Ajuste de Conduta, o reconhecimento administrativo de indenizações, além de tentativas de gerenciamento de demandas por medicamentos, com a finalidade de extingui-las por acordo. Além disso, são previstos alguns acordos por adesão no tocante a dívidas fiscais e precatórios. No âmbito judicial, contudo, a conciliação é praticamente inexistente. 
No tocante às causas que influenciam a adoção ou não de meios consensuais, notou-se que a compreensão dos advogados públicos quanto aos princípios de Direito Administrativo não são a principal causa, ainda que tenha sido identificada a existência de uma cultura de resistência, especialmente por parte dos procuradores atuantes no contencioso judicial, o que se dá mais pelos próprios condicionamentos de seu trabalho e pela preocupação com a responsabilização pessoal do que por uma leitura mais tradicional do Direito Administrativo.

O principal fator do baixo grau do uso sistêmico dos meios consensuais é a baixa regulação no âmbito do Município dos critérios para celebração de acordos, apesar de o Procurador-Geral e os Diretores dos Departamentos deterem competência para transacionar e firmar acordos.

Há receios em adotar um sistema consensual para tratamento de conflitos sem uma normatização correspondente, que balize os critérios de celebração dos acordos. As preocupações se voltam, sobretudo, (i) à necessidade de assegurar a isonomia; (ii) ao suporte normativo como forma de assegurar-se contra uma responsabilização pessoal e (iii) à necessidade de apoio político dos órgãos da Administração para adoção do sistema, o que pode conter um elemento de vontade política.

Há, ainda, questões de ordem prática, como a descentralização e o tamanho da Administração Municipal, o que demandaria instrumentos de centralização ou de acompanhamento de resolução de conflitos, com a forma de tornar o sistema mais racional e menos fragmentado.

Respondidas tais perguntas, está cumprida a missão da presente pesquisa. A partir dela, espera-se estimular a formulação de outras hipóteses para superação efetiva dos óbices identificados, para além das sugestões incidentalmente feitas, com objetivo de, por um lado, sustentar a implantação de um efetivo modelo de gestão adequada de conflitos, que supere a simples resistência e a judicialização reiterada. Ressaltando, contudo, que o uso de meios consensuais deve ser um instrumento de promoção de direitos, e não de sedimentação de opressões. Por isso, acrescentamos a essas considerações finais as observações feitas neste trabalho, no tocante à atenção que o desenvolvimento de qualquer sistema de resolução de conflitos deve ter com os vulneráveis, as minorias, aqueles que não têm voz nos processos democráticos tradicionais, e aqueles que não têm recursos para, sozinhos e com suas poucas armas, fazerem valer seus interesses. 


\section{REFERÊNCIAS}

ADVOCACIA-GERAL DA UNIÃO. Ementário da Conciliação na AGU/CGU Câmaras ad hoc. Brasília: AGU, 2009. Disponível em: < http://www.agu.gov.br/page/content/detail/id_conteudo/170561>. Acesso em: 07.08.2014.

ALESSI, Renato. Sistema istituzionale del diritto amministrativo italiano. Milano: Giuffrè, 1953.

ASPERTI, Maria Cecília de Araújo. Meios consensuais de resolução de disputas repetitivas: a conciliação, a mediação e os grandes litigantes do Judiciário. Dissertação (Mestrado) - Faculdade de Direito da Universidade de São Paulo. São Paulo, 2014.

ÁVILA, Humberto. Moralidade, razoabilidade e eficiência na atividade administrativa. Revista Eletrônica de Direito do Estado. Salvador, IBDP, n. 4, out./dez. 2005 , p. 19. Disponível em: < http://www.direitodoestado.com.br/artigo/humbertoavila/moralidade-razoabilidade-e-eficiencia-na-atividade-administrativa $>$.

AZEVEDO, André Gomma de. Novos desafios do acesso à justiça: novas perspectivas decorrentes de novos processos de resolução de disputas. SILVA, Luciana Aboim Machado Gonçalves da (org.). Mediação de conflitos. São Paulo: Atlas, 2013. Saraiva, 1994.

BASTOS, Celso Ribeiro. Dicionários de Direito Constitucional. São Paulo:

BEDAQUE, José Roberto dos Santos. Breves notas sobre jurisdição e ação. ZUFELATO, Camilo; YARSHELL, Flávio Luiz (org.). 40 anos da teoria geral do processo no Brasil: passado, presente e futuro. São Paulo: Malheiros, 2013.

BINENBOJIN, Gustavo. Da supremacia do interesse público ao dever de proporcionalidade: Um novo paradigma para o Direito Administrativo. Revista de Direito da Procuradoria Geral, Rio de Janeiro, n. 59, 2005.

BINENBOJM, Gustavo. Um novo direito administrativo para o século XXI. Temas de Direito Administrativo e Constitucional. Rio de Janeiro: Renovar, 2008.

BRAGA NETO, Adolfo. Reflexões sobre a conciliação e a mediação de conflitos. SALLES, Carlos Alberto de (coor.). As grandes transformações do processo civil brasileiro. São Paulo: Quartier Latin, 2009.

BRANDÃO, Marcella Araújo da Nova. A consensualidade e a administração pública em juízo. Dissertação (mestrado) - Escola de Direito da Fundação Getúlio Vargas, Rio de Janeiro, 2009.

BUENO, Cássio Scarpinella. Curso Sistematizado de Direito Processual Civil. São Paulo: Saraiva, 2010, v. 2, t. III. 

2003

BUENO, Cássio Scarpinella. O Poder Público em juízo. 2. ed. São Paulo: Saraiva,

BUSH, Baruch Robert A.; FOLGER, J. P. La promesa de mediación: Como Afrontar el Conflicto a Través del Fortalecimiento Propio y el Reconocimiento de los Otros. Buenos Aires: Granica, 1996.

CABRAL, Antonio. Os efeitos processuais da audiência pública. Revista Eletrônica de Direito Administrativo Econômico. Salvador, IBDP, n. 13, fev./abr. 2008.

CALMON, Petronio. Fundamentos da mediação e da conciliação. 2. ed. Brasília: Gazeta Jurídica, 2013.

CÂMARA DE CONCILIAÇÃO E ARBITRAGEM DA ADMINISTRAÇÃO FEDERAL. Cartilha. 3. ed. Brasília: AGU, 2011.

CAPPELLETTI, Mauro; GARTH, Bryant. Acesso à justiça (Trad. Ellen Gracie Northfleet). Porto Alegre: SAFE, 1998.

CARMONA, Carlos Alberto. Arbitragem e processo. 2. ed. São Paulo: Atlas, 2006.

CINTRA, Antonio Carlos de Araújo; GRINOVER, Ada Pellegrini; DINAMARCO, Cândido Rangel. Teoria geral do Processo. 20. ed. São Paulo: Malheiros, 2004.

CINTRA, Roberto Ferrari de Ulhôa. A pirâmide de solução de conflitos: uma contribuição de sociedade civil para a reforma do Judiciário. Brasília: Senado Federal, 2008 .

COMISSÃO DE VALORES IMOBILIÁRIOS. Termos de compromisso celebrados com a CVM - Índice geral. Disponível em: < http://www.cvm.gov.br/port/inqueritos/Termos/TermosCompr.asp>. Acesso em: $14 / 12 / 2014$.

CONSELHO NACIONAL DE JUSTIÇA. 100 maiores litigantes. Brasília: CNJ, 2011

CONSELHO NACIONAL DE JUSTIÇA. 100 maiores litigantes - 2012. Brasília: CNJ, 2012.

CONSELHO NACIONAL DE JUSTIÇA. Relatório precatórios. Brasília: CNJ, 2012, p. 95-97. Disponível em: $<$ http://www.cnj.jus.br/images/imprensa/precatorios/realtorio_precatorios_CNJ_FINAL1.p df $>$. Acesso em: 31.11.2014.

COSTA, Susana Henriques da. Comentário ao art. $5^{\circ}$ da Lei de Ação Civil Pública. (coor.). Comentários à Lei de Ação Civil Pública e à Lei de Ação Popular. São Paulo: Quartier Latin, 2006. 
COSTA, Susana Henriques da. O controle judicial da representatividade adequada: uma análise dos sistemas norte-americano e brasileiro. SALLES, Carlos Alberto de. As grandes transformações do processo civil brasileiro: homenagem ao Professor Kazuo Watanabe. São Paulo: Quartier Latin, p. 953-978, 2009.

COSTA, Susana Henriques. O processo coletivo na tutela do patrimônio público e da moralidade administrativa. São Paulo: Quartier Latin, 2009.

CUNHA, Leonardo Carneiro da. A fazenda pública em juízo. 12. ed. São Paulo: Dialética, 2014.

CUNHA, Luciana Gross; GABBAY, Daniela Monteiro (coor.). O desenho de sistemas de resolução alternativa de disputas para conflitos de interesse público. Brasília: Secretaria de Assuntos Legislativos do Ministério da Justiça, 2011.

DIDIER JR., Fredie. Curso de direito processual civil. 14. ed., Salvador: JusPodivm, 2012.

DINAMARCO, Cândido Rangel. Instituições de direito processual civil. 7. ed. São Paulo: Malheiros, 2013, v. 1.

DINAMARCO, Cândido Rangel. Manual das pequenas causas. São Paulo: RT, 1986.

DINIZ, Maria Helena. Curso de Direito Civil Brasileiro. 19. ed. São Paulo: Saraiva, 2004.

DI PIETRO, Maria Sylvia Zanella. Direito Administrativo. 20. ed. São Paulo: Atlas, 2007.

DI PIETRO, Maria Sylvia Zanella. Discricionariedade administrativa e controle judicial da administração. SALLES, Carlos Alberto de (org.). Processo civil e interesse público: o processo como instrumento de defesa social. São Paulo: RT, 2003.

ECONOMIDES, Kim. Lendo as ondas do "Movimento de Acesso à Justiça": epistemologia versus metodologia? PANDOLFI, Dulce... [et. al]. Cidadania, justiça e violência. Rio de Janeiro: Ed. Fundação Getulio Vargas, 1999.

FADANELLI, Vinícius Krüger Chalub. Termo do compromisso em processo administrativo sancionador da Comissão de Valores Mobiliários. Dissertação (mestrado) - Faculdade de Direito da Universidade de São Paulo (USP), São Paulo, 2013.

FALLEIROS, Carolina Teodoro. Alcance subjetivo das decisões judiciais sobre interesses metaindividuais. Dissertação (Mestrado) - Faculdade de Direito da Universidade de São Paulo. São Paulo, 2014.

FARIA, José Eduardo. A definição de interesse público. SALLES, Carlos Alberto de (org.). Processo civil e interesse público: o processo como instrumento de defesa social. São Paulo: RT, 2003. 
FIGUEIRA JÚNIOR, Juizados especiais estaduais cíveis e criminais. 4. ed. São Paulo: RT, 2005.

FISHER, Roger; URY, William; PATTON, Bruce. Getting to Yes: Negotiation agreement without giving in. 3. ed. New York: Penguin Books, 2011.

FISS, Owen. Against Settlement. The Yale Law Journal, New Haven, v. 93, n. 6, mai./1984.

FREITAS JR., Antonio Rodrigues de. Conflitos de Justiça e limites da mediação para a difusão da cultura de paz. SALLES, Carlos Alberto de. As grandes transformações do processo civil brasileiro: homenagem ao Professor Kazuo Watanabe. São Paulo: Quartier Latin, 2009.

FREITAS JR., Antonio Rodrigues. Sobre a relevância de uma noção precisa de conflito. Revista do Advogado. São Paulo, AASP, n. 123, p. 11-23, ago./2014.

FULLER, Lon Luvois. Collective bargaining and the arbitrator. Wisconsin Law Review, Wisconsin, n. 18, p. 3-47, 1963.

GABBAY, Daniela Monteiro. Mediação e Judiciário: Condições necessárias para a institucionalização dos meios autocompositivos de solução de conflitos. Tese (Doutorado) - Faculdade de Direito da Universidade de São Paulo. São Paulo, 2011.

GAJARDONI, Fernando da Fonseca; ROMANO, Michel Betenjane; LUCHIARI, Valeria Ferioli Lagrasta. O gerenciamento do processo. GRINOVER, Ada Pellegrini; WATANABE, Kazuo; LAGRASTA NETO, Ceatano. Mediação e Gerenciamento do Processo. Rio de Janeiro: Atlas, 2007.

GALANTER, Marc. Why the haves come out ahead: speculations on the limits of legal change. Law and Society Review, Denver, v. 9, n. 1, p. 95-160, 1974.

GAMA, Evandro. Conciliação e transação nas causas de natureza tributária nos Juizados Especiais Federais. GUEDES, Emmerson Carús (org.). Juizados Especiais Federais. Rio de Janeiro: Forense, 2005.

GARCEZ, José Maria Rossani. O Estado, suas agências, as empresas públicas e as sociedades de que participa na arbitragem privada. Recentes progressos. Revista de Arbitragem e Mediação, São Paulo, Revista dos Tribunais, n. 8, p. 101-118, jan./mar. 2006.

GAZDA, Emmerson. Administração Pública em juízo: poder-dever de transigir. Revista da Associação dos Juízes Federais do Brasil, v. 23, $\mathrm{n}^{\circ} .83$, p.131-158, jan/mar 2006. Disponível em: http://www.revistadoutrina.trf4.jus.br/index.htm?http://www.revistadoutrina.trf4.jus.br/arti gos/edicao010/emmerson_gazda.htm>. Acesso: 04.07.2014.

GHIRARDI, José Garcez; PALMA, Juliana Bonacorsi de; VIANA, Manuela Trindade. Posso fazer um trabalho inteiro sobre um caso específico? QUEIROZ, Rafael 
Mafei Rabelo; FEFERBAUM, Marina (coord.). Metodologia jurídica: um roteiro prático para trabalhos de conclusão de curso. São Paulo: Saraiva, 2012.

GLEBER, Eduardo. A solução de controvérsias em contratos de parceria públicoprivada. Revista de Arbitragem e Mediação, São Paulo, Revista dos Tribunais, n. 2, p. 60-73, mai./ago. 2004.

GRAU, Eros. Da arbitrabilidade de litígios envolvendo sociedades de economia mista e da interpretação de cláusula compromissória. Revista de Direito Bancário e Mercado de Capitais. São Paulo, RT, n. 18, p. 395-405, out./dez. 2002.

GUEDES, Jefferson Carús. Transigibilidade de interesses públicos: prevenção e abreviação de demandas da Fazenda Pública. GUEDES, Jefferson Carús; SOUZA, Luciane Moessa de. Advocacia de Estado: questões institucionais para a construção de um Estado de justiça. Belo Horizonte: Fórum, 2009. 2013.

JUSTEN FILHO, Marçal. Curso de Direito Administrativo. 9. ed. São Paulo: RT,

KOVACH, Kimberlee K. Mediation: Principles and Practice. 3. ed. St. Paul: Thomson West, 2004

LEMES, Selma. Arbitragem na Administração Pública. São Paulo: Quartier Latin, 2007.

LEONEL, Ricardo de Barros. Manual do processo coletivo. 2. ed. São Paulo: RT, 2011.

LORENCINI, Marco Antônio Garcia Lopes. "Sistemas multiportas": opções para tratamento de conflitos de forma adequada. SALLES, Carlos Alberto; LORENCINI, Marco Antônio Garcia. SILVA, Paulo Eduardo Alves da. Negociação, mediação e arbitragem: curso básico para programas de graduação em Direito. São Paulo: Método, 2012.

MANCUSO, Rodolfo de Camargo. Acesso à justiça: condicionantes legítimas e ilegítimas. São Paulo: RT, 2011.

MANCUSO, Rodolfo de Camargo. Ação Civil Pública. 13. ed. São Paulo: RT, 2014.

MANCUSO, Rodolfo de Camargo. Divergência jurisprudencial e súmula vinculante. 5. ed. São Paulo: RT, 2013.

MANCUSO, Rodolfo de Camargo. Interesses difusos: conceito e legitimação para agir. 6. ed. São Paulo: RT, 2004.

MANCUSO, Rodolfo de Camargo. O direito à tutela jurisdicional: o novo enfoque do art. $5^{\circ}$, XXXV, da Constituição Federal. Revista dos Tribunais, São Paulo: RT, v. 926, dez./2012, p. 135-176. 
MANCUSO, Rodolfo de Camargo. O plano piloto de conciliação em segundo grau de jurisdição, do Egrégio Tribunal de Justiça de São Paulo e sua possível aplicação aos feitos da Fazenda Pública. Revista dos Tribunais, n. 820, p. 11-49, fev./2004.

MARQUES, Floriano Azevedo. Discricionariedade administrativa e controle judicial da administração. SALLES, Carlos Alberto de (org.), Processo civil e interesse público: o processo como instrumento de defesa social. São Paulo: RT, 2003.

MEDAUAR, Odete. A processualidade no direito administrativo. São Paulo: RT, 1993. 2012.

MEDAUAR, Odete. Direito Administrativo Moderno. 16. ed. São Paulo: RT,

MELlo, Celso Antonio Bandeira de. Conteúdo jurídico do principio da igualdade. 3. ed. São Paulo: Malheiros, 2009.

MELlo, Celso Antônio Bandeira de. Curso de Direito Administrativo. 31 ed. São Paulo: Malheiros, 2014.

MELlO, Celso Antonio Bandeira de. O conteúdo do regime jurídicoadministrativo e seu valor metodológico. Revista de Direito Público n. 2. São Paulo: RT, 1967

MENDONÇA, Angela Hara Buonomo. A reinvenção da tradição do uso da mediação. Revista de Arbitragem e Mediação. São Paulo, RT, n. 3, p. 142-153, set./dez. 2004

MENKEL-MEADOW, Carrie. Roots and Inspirations: A Brief History of the Foundations of Dispute Resolution. MOFFITT, Michael L.; BORDONE, Robert C. (coord.). The Handbook of Dispute Resolution. San Francisco: Jossey-Bass, 2005, p. 1331

MENKEL-MEADOW, Carrie J.; LOVE, Lela Porter; SCHNEIDER, Andrea Kupfer; STERNLIGHT, Jean R. Dispute resolution: beyond the adversarial model. New York: Aspen, 2005.

MILARÉ, Édis. Direito do ambiente. 7. ed. São Paulo: RT, 2011.

MIRANDA NETTO, Fernando Gama de; MEIRELLES, Delton Ricardo Soares. Mediação judicial no Projeto do novo Código de Processo Civil (PL 8.046/2010). Revista de Arbitragem e Mediação, São Paulo, RT, v. 33, p. 213-235, abr./jun. 2012.

MONTEIRO, Alexandre Luiz Moraes do Rego; CASTRO, Leonardo Freitas de Moraes e. Direito Tributário e Arbitragem: uma análise da possibilidade e dos óbices ao juízo arbitral em matéria tributária no Brasil. Revista de Mediação e Arbitragem. São Paulo, RT, n. 23, p. 60-88, out./dez. 2009.

MORAES, Luiza Rangel de. Arbitragem e agências reguladoras. Revista de Arbitragem e Mediação, São Paulo, Revista dos Tribunais, n. 2, p. 74-89, mai./ago. 2004. 
MOREIRA, José Carlos Barbosa. Reforma do Judiciário: a Emenda Constitucional $\mathrm{n}^{\mathrm{o}} 45$ e o Processo. Revista Magister de Direito Civil e Processual Civil, n. 11, mar/abr 2006 .

MOURÃO, Alessandra Nascimento S. F. et al. Resolução de conflitos: Fundamentos da Negociação para o ambiente jurídico. São Paulo: Saraiva (Série GVlaw), 2014.

MUNIZ, Joaquim de Paiva. Os limites da arbitragem nos contratos de concessão de exploração e produção de petróleo e gás natural. Revista de Arbitragem e Mediação, São Paulo, Revista dos Tribunais, n. 2, p. 90-101, mai./ago. 2004.

NAMBLARD, Corinne. Para um enfoque pragmático de parceria público-privada. apud OLIVEIRA, Gustavo Henrique Justino de. A arbitragem e as parcerias públicoprivadas. Revista Eletrônica de Direito Administrativo Econômico. Salvador, IDPB, n. 2, mai./jul. 2005.

OLIVEIRA, Gustavo Justino de. A Administração consensual como a nova face da Administração pública no século XXI: fundamentos dogmáticos, formas de expressão e instrumentos de ação. OLIVEIRA, Gustavo Justino de. Direito administrativo democrático. Belo Horizonte: Fórum, p. 211-231, 2010.

OLIVEIRA, Gustavo Henrique Justino de. A arbitragem e as parcerias públicoprivadas. Revista Eletrônica de Direito Administrativo Econômico. Salvador, IDPB, n. 2, mai./jul. 2005.

OLIVEIRA, Gustavo Justino de; SCHWARTSMANN, Guilherme Batista. Mediação e Administração Pública no Brasil: análise do Projeto de Lei n. 517/2011, p. 6. Disponível em: <http://www.justinodeoliveira.com.br/wpcontent/uploads/2014/05/MEDIAÇÃO-E-ADMINISTRAÇÃO-PÚBLICA-NOBRASIL_2014.05.pdf>. Acesso em: 10.09.2014.

OLIVEIRA, Gustavo Justino de. O setor público é obrigado a buscar soluções para os seus conflitos sem recorrer ao Judiciário: o papel da mediação, conciliação e arbitragem para a atual administração pública brasileira. Disponível em: <http://www.justinodeoliveira.com.br/wp-content/uploads/2011/10/litigancia-no-setorpublico.pdf>. Acesso em: 10 set. 2014.

PALMA, Juliana Bonacorsi de. A consensualidade na Administração Pública e seu controle judicial. GABBAY, Daniela Monteiro; TAKAHASHI, Bruno (coor.). Justiça Federal: inovações nos mecanismos consensuais de solução de conflitos. Brasília: Gazeta Jurídica, 2014.

PALMA, Juliana Bonacorsi de. Atuação Administrativa consensual: Estudo dos Acordos Substitutivos no processo administrativo sancionador. Dissertação (mestrado), São Paulo, Faculdade de Direito da Universidade de São Paulo, 2010. 
PASSOS, Celia Maria Oliveira. Prática da Mediação na Agência Nacional de Telecomunicações. Dissertação (mestrado em Direito e Sociologia) - Universidade Federal Fluminense (UFF), Rio de Janeiro, 2008.

PEREIRA NETO, Caio Mario da Silva; MATOS, Paulo Todescan Lessa. A crise da pesquisa em direito no Brasil: Armadilhas e alternativas ao formalismo jurídico. Disponível em: <http://www.law.yale.edu/documents/pdf/sela/CaiodaSilvaPereiraandPauloTodescanLessaMattos Portu guese .pdf $>$. Acesso em: 12 set. 2013.

PORTO, Pedro Rui da Fontoura. Violência doméstica e familiar contra a mulher: Lei n. 11.340/06 - análise crítica e sistêmica. Porto Alegre: Livraria do Advogado, 2007.

QUEIROZ, Rafael Mafei Rabelo. Como encontrar um bom tema dentro de minha área de interesse? QUEIROZ, Rafael Mafei Rabelo; FEFERBAUM, Marina (coord.). Metodologia jurídica: um roteiro prático para trabalhos de conclusão de curso. São Paulo: Saraiva, 2012.

ROCHA, Cármen Lúcia Antunes. O princípio constitucional da igualdade. Belo Horizonte: Lê, 1990.

ROBERTS, Simon; PALMER, Michael. Dispute processess: ADR and the primary forms of decision-making. Cambridge: Cambridge University Press, 2005.

SALLES, Carlos Alberto de. Arbitragem em contratos administrativos, São Paulo: Método, 2011.

SALLES, Carlos Alberto de. Mecanismos alternativos de solução de controvérsias e acesso à justiça: inafastabilidade da tutela jurisdicional recolocada. FUX, Luiz; NERY JR., Nelson; WAMBIER, Teresa Arruda Alvim (coor.). Processo e Constituição: Estudos em homenagem ao Professor José Carlos Barbosa Moreira. São Paulo: RT, 2006, p. 779792.

SALLES, Carlos Alberto. Processo Civil de interesse público: uma nova perspectiva metodológica. SUNDFELD, Carlos Ari; BUENO, Cassio Scarpinella. Direito Processual Público: A Fazenda Pública em Juízo. São Paulo: Malheiros, 2000.

SAMPAIO, Lia Regina Castaldi; BRAGA NETO, Adolfo. O que é mediação de conflitos. São Paulo: Brasiliense, 2007.

SANDER, Frank E. A. Varieties of Dispute Processing. LEVIN, Leo A.; WHEELER, Russell R (edit.). The Pound Conference: Perspectives on Justice in the future. St. Paul, MN: West Publishing, 1979.

SECRETARIA DE REFORMA DO JUDICIÁRIO. Acesso à Justiça por Sistemas Alternativos de Administração de Conflitos. Brasília: SRJ, 2005, p. 24. Disponível em: < $\quad$ http://portal.mj.gov.br/reforma/main.asp?View=\%7B597BC4FE-7844-402D-BC4B06C93AF009F0\%7D>. 
SERAU JÚNIOR, Marco Aurélio. Conciliação nas ações previdenciárias. Revista do Advogado. São Paulo, AASP, n. 123, ago./2014.

SILVA, Érica Barbosa e; TARTUCE, Fernanda. A conciliação diante da política judiciária de tratamento adequado de conflitos. In: TUCCI, José Rogério Cruz e; RODRIGUES, Walter Piva; AMADEO, Rodolfo da Costa Manso Real. (Org.). Processo Civil: Homenagem a José Ignacio Botelho De Mesquita. 1ed.São Paulo: Quartier Latin, 2013.

SILVA, José Afonso da. Comentário contextual à Constituição. 8. ed. São Paulo: Malheiros, 2012.

SILVA, José Afonso da. Curso de Direito Constitucional Positivo. 26. ed. São Paulo, 2004.

SILVA, Paulo Eduardo Alves da. Condução planejada dos processos judiciais: a racionalidade do exercício jurisdicional entre o tempo e forma do processo. Tese de Doutorado, Faculdade de Direito da USP, 2005.

SILVA, Paulo Eduardo Alves da. Mediação e conciliação, produtividade e qualidade. Revista do Advogado. São Paulo, AASP, n. 123, ago./2014.

SILVA, Paulo Eduardo Alves da. Solução de controvérsias: métodos adequados para resultados possíveis e métodos possíveis para resultados adequados. SALLES, Carlos Alberto; LORENCINI, Marco Antônio Garcia. SILVA, Paulo Eduardo Alves da. Negociação, mediação e arbitragem: curso básico para programas de graduação em Direito. São Paulo: Método, 2012.

SOUZA, Luciane Moessa de. Advocacia de Estado: questões institucionais para a construção de um estado de justiça - Estudos em homenagem a Diogo de Figueiredo Moreira Neto e José Antonio Dias Toffoli. Belo Horizonte: Fórum, 2009.

SOUZA, Luciane Moessa de. Meios consensuais de solução de conflitos envolvendo entes públicos: negociação, mediação e conciliação na esfera administrativa e judicial. Belo Horizonte: Fórum, 2012.

SOUZA, Luciane Moessa de. Resolução consensual de conflitos envolvendo o Poder Público: caminho possível e adequado, com o devido respeito às peculiaridades do regime jurídico-administrativo. Revista do Advogado. São Paulo, AASP, n. 123, ago.2014.

SOUZA, Michel Roberto. Recurso especial repetitivo: análise crítica do julgamento por amostragem. Dissertação (Mestrado) - Faculdade de Direito da Universidade de São Paulo. São Paulo, 2014.

SUNDFELD, Carlos Ari. Princípio é preguiça? Direito Administrativo para céticos. São Paulo: Malheiros, 2012. 
SUNDFELD, Carlos Ari; CÂMARA, Jacintho Arruda. Acordos na execução contra a Fazenda Pública. Revista Eletrônica de Direito Administrativo Econômico. Salvador, IBDP, n. 23, ago./out. 2010.

TAKAHASHI, Bruno. Dilemas éticos de um conciliador. Revista do Advogado, São Paulo, AASP, n. 123, p. 62-69, ago./2014.

TALAMINI, Eduardo. A (in)disponibilidade do interesse público: consequências processuais. Revista de Processo, São Paulo, RT, n. 128, p. 59-77, out./2005.

TARTUCE, Fernanda. Conciliação e Poder Judiciário. Disponível em www.fernandatartuce.com.br. Acesso em: 05.10.2014.

TARTUCE, Fernanda. Conciliação em juízo: o que (não) é conciliar? SALLES, Carlos Alberto; LORENCINI, Marco Antônio Garcia Lopes; SILVA, Paulo Eduardo Alves da. Negociação, mediação e arbitragem: curso básico para programas de graduação em Direito. São Paulo: Método, 2013.

TARTUCE, Fernanda. Igualdade e vulnerabilidade no processo civil. Rio de Janeiro: Forense, 2012.

TARTUCE, Fernanda. Lei n. 11.232, art. 475-N, inciso IV: acordo extrajudicial de qualquer natureza homologado em juízo como título executivo judicial. Revista EPD, São Paulo, EPD, v. 3, p. 233-252, 2006.

TARTUCE, Fernanda. Mediação nos conflitos civis. São Paulo: Método, 2007.

TARTUCE, Fernanda; BERGAMASCHI, André Luís. A solução negociada e a figura jurídica da transação: associação necessária? SIMÃO FILHO, Adalberto; MEDEIROS NETO, Elias Marques de; FIGUEIRA, Janahim Dias (coor.). Direito dos negócios aplicado, v. II - do direito processual (no prelo).

TARTUCE, Fernanda; BERGAMASCHI, André Luís. Repercussão Geral da Questão Constitucional em Demandas Familiares. FUX, Luiz; FREIRE, Alexandre; DANTAS, Bruno (Org.). Repercussão Geral da Questão Constitucional. Rio de Janeiro: Forense, 2014, p. 53-70, v. 1.

TARTUCE, Fernanda; FALECK, Diego. Introdução histórica e modelos de mediação. TOLEDO, Armando Sérgio Prado de.; TOSTA, Jorge; ALVES, José Carlos Ferreira (Org.). Estudos Avançados de Mediação e Arbitragem. Rio de Janeiro: Elsevier.

TARTUCE, Fernanda; FALECK, Diego; Gabbay, Daniela. Meios alternativos de solução de conflitos. Rio de Janeiro: FGV, 2014.

TARUFFO, Michele. Páginas sobre justicia civil (Trad. Maximiliano Aramburo Calle). Madrid: Marcial Pons, 2009. 
VIEIRA, Oscar Vilhena; ALMEIDA, Eloísa Machado de. Advocacia estratégica em Direitos Humanos: a experiência do Conectas. Revista Internacional de Direitos Humanos, Sur, n. 15, p. 187-213, dez./2011.

VOLPI, Elon Kaleb Ribas. Conciliação na Justiça Federal: A indisponibilidade do interesse público e a questão da isonomia. Revista da PGFN. Brasília, PGFN, ano 1, n. 2, p. 139-164, 2011.

WALD, Arnoldo. A arbitragem contratual e os dispute boards. Revista de Arbitragem e Mediação. São Paulo:RT, n. 6, jul./set. 2005.

WANG, Daniel Wei Liang. Poder Judiciário e participação democrática nas políticas de saúde. Dissertação (mestrado), São Paulo, Faculdade de Direito da Universidade de São Paulo, 2009.

WATANABE, Kazuo. Acesso à justiça e sociedade moderna. GRINOVER, Ada Pellegrini; DINAMARCO, Cândido Rangel; WATANABE, Kazuo. Participação e processo. São Paulo: RT, p. 128-135, 1988.

WATANABE, Kazuo. Cultura de sentença e Cultura de Pacificação. YARSHELL, Flávio Luiz (coor.). Estudos em homenagem à Professora Ada Pellegrini Grinover. São Paulo: DPj, 2005. 


\section{Apêndice 1 - $\underline{\text { Roteiro de entrevista utilizado na PGM-SP }}$}

Nome:

Data:

Objetivos da entrevista: 1) obter informações sobre o uso de meios consensuais na PGM;

2) Entender as motivações para uso/não uso de meios consensuais na PGM.

Método: entrevista mista entre semiestruturada e aberta

1 - Perguntas de identificação

1.1. Hoje, com que área você lida dentro da PGM?

1.2. Você lida de alguma forma com divergências entre o Município e outros particulares ou entes públicos? - Explique um pouco melhor seu trabalho.

1.3. Há espaço na sua atuação para utilização de meios consensuais?

2 - Perguntas sobre opinião e percepção geral

2.1. O que você entende por "meios consensuais de solução de controvérsias"?

2.2. Como você vê a relação entre o trabalho da PGM e a utilização de meios consensuais? Há espaço, em tese, para sua utilização?

2.3. Você crê que os meios consensuais são desejáveis no âmbito da PGM?

2.4. Como você vê na prática, no seu departamento, a utilização dos meios consensuais na PGM? Eles são efetivamente utilizados?

2.4.1. Por que são ou não utilizados em tais situações?

2.5. Quais as principais barreiras que você enxerga à utilização dos meios consensuais?

2.6. Se eu disser alguns conceitos, você diria se eles influem na opção de utilizar ou não um meio consensual?

- Isonomia.

- Supremacia do interesse público

- Legalidade

- Indisponibilidade do interesse público

- Responsividade ou prestação de contas

2.7. A estrutura de competências dentro da Administração e da PGM é um entrave para a utilização dos meios alternativos? É caso de conferir maior liberdade aos procuradores nos níveis mais diretos de envolvimento com os processos judiciais e com a população? 
2.8. Há estímulos institucionais para a utilização de meios consensuais? Se houvesse, por exemplo, estímulos financeiros, haveria alguma diferença na prática da PGM?

2.9. Na sua visão, a Administração (através da procuradoria) tem autonomia para acatar interpretações do Judiciário sobre a lei para a finalidade de celebração de acordos ou mesmo para reconhecimento administrativo de direitos?

3 - Perguntas sobre a atuação específica

3.1. Você já utilizou alguma vez algum meio consensual em seu trabalho? Como foi sua experiência?

3.3. Você acredita que eles poderiam te ajudar no seu trabalho?

3.4. Que barreiras você vê especificamente no seu trabalho para a utilização de meios consensuais?

4 - Perguntas sobre riscos

4.1. Quais os riscos que você vê com a adoção de métodos consensuais pela Prefeitura de São Paulo?

7 - Perguntas de exploração do tema

7.1. Onde há espaço para utilização de meios consensuais na PGM?

7.2. Conhece algum caso que valha a pena explorar? 